\title{
Visões da travessia: imersões na paisagem
}

Dissertação apresentada à Faculdade de Arquitetura e Urbanismo da Universidade de São Paulo para obtenção do título de Mestre em Arquitetura e Urbanismo.

Área de Concentração: Paisagem e Ambiente. 
Autorizo a reprodução e divulgação total ou parcial deste trabalho, por qualquer meio convencional ou eletrônico, para fins de estudo e pesquisa, desde que citada a fonte.

Catalogação na Publicação

Serviço Técnico de Biblioteca
Faculdade de Arquitetura e Urbanismo da Universidade de São Paulo

Maranhão, Francisco Horta de Albuquerque

Visões da travessia: imersões na paisagem / Francisco Horta de Albuquerque Maranhão; orientador Vladimir

$$
284 \text {. }
$$

Dissertação (Mestrado) - Faculdade de Arquitetura Danismo da Universidade de São Paulo. Área de

concentração: Paisagem e Ambiente.

1. Paisagem. 2. Pintura. 3. Desenho. 4. Rio Pinheiros. I. Bartalini, Vladimir, orient. II. Título.

Elaborada eletronicamente através do formulário disponivel em: <http://www.fau.usp.br/fichacatalografica/ 
MARANHÃO, F. H. A.

Visões da travessia: imersões na paisagem.

Dissertação apresentada à Faculdade de Arquitetura e Urbanismo da Universidade de São Paulo para obtenção do título de Mestre em Arquitetura e Urbanismo.

Área de Concentração: Paisagem e Ambiente.

Aprovado em:

Banca Examinadora

Prof. Dr.:
Instituição:
Julgamento:

Prof. Dr.

Julgamento:
Prof. Dr.:

Instituição:

Julgamento: 

A meu pai, que foi o maior contador de histórias, e o primeiro a quem falei sobre a intenção de contar esta. 



\section{Agradecimentos}

Agradeço ao meu orientador Vladimir Bartalini, pela imensa generosidade e cuidado dedicado à minha pesquisa, sempre incentivando seu desenvolvimento no sentido de minhas verdadeiras motivações;

À Capes, cujo auxílio financeiro foi fundamental à produção do trabalho ao longo deste último ano.

Ao professor Marco Buti, que foi o primeiro professor a me mostrar a história das paisagens na arte, com quem pude conversar na gestação do projeto, e aos professores Marco Giannotti e Claudio Mubarac, que também trouxeram boas ideias.

Estendo os agradecimentos às professoras Klara Kaiser e Vera Pallamin, e ao professor Feres Khoury, com quem também pude conversar para esclarecer quais os caminhos a serem tomados no início do projeto.

Agradeço à Olgaria Matos, que também participou da criação e desenvolvimento do projeto com ótimas referências e conversas acompanhadas do melhor café.

Agradeço também ao Valdir e ao Sr. Antonio Albuquerque pelos macetes de impressão e pela técnica do açúcar.

À Tetê Louro, grande pintora e desenhista, professora e prima com quem pude conversar sobre o trabalho.

À minha irmã Helena, exemplo de perseverança e força para escrever, e para todo o resto.

À minha mãe Regina, revisora incondicional e portadora das melhores referências.

E à Berta, responsável pela diagramação do livro, fonte de companheirismo, incentivo e inspiração sem fim, desde as primeiras margens. 

Título da dissertação: Visões da travessia: imersões na paisagem

\section{Resumo:}

Nesta dissertação, desenvolve-se um estudo prático e teórico sobre a percepção da paisagem nas ambientações urbanas contemporâneas, no que toca à sua relação com a história da paisagem enquanto representação pictórica e gráfica.

Partindo de um estudo de caso empírico, a pesquisa consiste no registro visual da paisagem compreendida em torno das margens do rio Pinheiros, na cidade de São Paulo SP, por meio do desenho e da pintura. É importante destacar que a presença do rio como mediador de uma relação com a paisagem se mostrará prenhe de uma série de significados relevantes sobre a experiência da natureza em meio ao contexto urbano, assim como aspectos de uma associação fundamental da ideia de paisagem com a figura dos rios,

Segundo o exame das imagens produzidas e coletadas ao longo de percursos pelas margens desse rio, articulam-se as qualidades e conteúdos visuais presentes em tais imagens com questões pertinentes ao debate teórico e histórico sobre a paisagem como experiência estética e como objeto das artes visuais.

Palavras-chave: Artes Visuais. Desenho. Paisagem. Pintura. Representação. Rio Pinheiros. Rios Urbanos 

Title: Visions of the crossing : immersions in the landscape

\section{Abstract:}

In this dissertation, it is developed a practical and theoretical study about the perception of landscape in contemporary urban environments, regarding its relation with the history of landscape in terms of graphical and pictorial representation.

Departing from an empirical case study, the research consists of visual depictions of the landscape settled along the margins of the Pinheiros River, in the city of São Paulo, SP - Brazil, by means of drawing and painting. It is important to state that the presence of the river as an intermediary in the relation between the citizen and the landscape carries a number of relevant significations about the experience of nature in the urban context, as though it carries aspects of a fundamental association of the Idea of landscape with the image of the river.

The analysis of the images made and collected from the observation of the margins in trajectories along the course of the referred river intents to articulate their visual characteristics and contents with the issues of the theoretical and historical debate about landscape as an aesthetic experience as thogh as a subject of the visual arts.

Keywords: Drawing. Fine Arts. Landscape. Painting. Pinheiros River. Representation. Urban Rivers. 



\section{SUMÁRIO}

Introdução

1. O rio, as margens e a memória das paisagens

Entre margens, a travessia

1.1. A água e o relevo

1.2. O rio como narrativa das paisagens

1.3. A questão da perspectiva

1.4. A autonomia da paisagem: do jardim do Éden ao mundo da percepção

2. Diante da margem do rio - a horizontalidade

O céu como luminosidade

O nó da linha do rio é a ponte

A paisagem do rio como linha

2.1. O registro geográfico das paisagens

A paisagem como expressão da luz

A paisagem como descrição

2.2. O impulso cartográfico

Vistas topográficas

Pintura, descrição, Corografia

A cartografia como hábito

114

Planaridade da terra e continuidade com o meio urbano 
3. Pirajuçara: uma imersão em um dos braços rio pinheiros

3.1. O ideal nas paisagens

3.2. Realismo, naturalismo e a unidade da paisagem

A unidade atmosférica

3.3. Da sensação à impressão

4. De volta às margens do rio Pinheiros

4.1. Rumo à abstração: a paisagem moderna como sintaxe da percepção

A destruição das aparências e a pureza estética

4.2. A paisagem na pintura desde os anos 1950 - figuração $x$ abstração O exemplo de Richard Diebenkorn

4.3. Em direção às paisagens contemporâneas 
INTRODUÇÃO 


\section{Por que o Rio Pinheiros?}

Na página anterior [imagem 1], Pi-ierê (enterrados vivos), 2015. Xilogravura sobre papel whenzou. $230 \times 80 \mathrm{~cm}$.
Este trabalho é fruto da aproximação entre as motivações de uma produção artística e a ideia de paisagem na história da arte, cujo início se deu com a produção de obras gráficas em que figuravam as águas e os rios. Da figuração de rios imaginários, surgiu o interesse pelo rio simbólico, e as associações poéticas que se faz entre o rio como forma e o rio como ideia. A constatação de que sob a ideia do rio estão depositadas camadas milenares de significados míticos e filosóficos, e de que sua importância enquanto figura histórica se expressa em diversos campos da cultura, acabou por envolver o rio , enquanto ideia, em uma "paisagem cultural": não mais se podia pensá-lo isolado de seu contexto, pois todo um mundo de significados e formas se joga às suas margens.

A relação teórica e poética que se estabeleceu em mim com uma ideia de rio teve rebatimento imediato com a experiência cotidiana de um rio na cidade de São Paulo, no caso o rio Pinheiros. Um rio que anteriormente não significava mais do que a sua poluição, o mau cheiro, e o isolamento em relação aos passeios da cidade, passou a ganhar uma nova qualidade e colorações menos repulsivas. A criação de uma ciclovia que corre à sua margem leste possibilitou a descoberta de um novo mundo dentro da cidade de São Paulo, que reestruturou a percepção que se tinha da cidade à sua volta anteriormente. É nesse momento que a ideia poética do rio ganha contornos paisagísticos. Passa-se a ver uma paisagem rica de uma estranha e mórbida beleza, onde antes só se via marginalidade.

Antes de compor a paisagem que vemos hoje, o rio Pinheiros era um rio meandrante, que foi brutalmente transformado, como podemos ver na gravura ao lado. Nela, podemos ler ENTERRADOS VIVOS, em razão da brutalidade da canalização de sua várzea, e PI-IERÊ, que significa, em tupi, “transbordar”. Há rumores de que seu nome possa estar relacionado a uma corruptela dessa palavra em tupi; contudo, é mais provável que sua nomeação se deva à presença, no passado, das araucárias em sua várzea. O símbolo da araucária presente nas caixas de fósforos "PINHEIRO” se soma ao conjunto de alego- 
1. GRINSPUM, Gabriel Rodrigues - Metamorfose da várzea paulistana: energia, saneamento e urbanização. -- São Paulo, 2014.p 30-31. "O Rio Pinheiros pode ser descrito, hoje, como dois lagos entrincheirados entre os reservatórios do Projeto da Serra e a confluência com o Rio Tietê; uma água parada, sem movimento, sem vida." 43 Cf. SIMMEL, Georg, " $A$ metrópole e a vida mental” In.VELHO, Otávio Guilherme, $O$ fenômeno urbano, Rio de Janeiro, Zahar editores, 1967 rias à memória deste rio morto-vivo.

Ao longo da segunda metade do século XX, foi feita tabula rasa da várzea do rio Pinheiros e passamos, atualmente, pela reinvenção de uma paisagem às suas margens. A proposta deste estudo se pauta no reconhecimento da trajetória metamórfica de refundação desta paisagem. Interessam-nos, portanto, o caráter transitório e precário de sua configuração visual, em processo de transformação, e, consequentemente, os índices de uma linguagem de sua apreensão sensível e da forma como ela se constitui em representação.

O rio Pinheiros é, atualmente, o mais vivo entre os rios mortos da cidade de São Paulo. Apesar da sua condição de "esgoto a céu aberto", ele é ainda hoje, ao lado dos rios Tietê e Tamanduateí, elemento incontornável de orientação do citadino, e configura-se em suas margens uma paisagem que, para muitos, de tão vista, tende à invisibilidade.

Contudo, ocorre, nos últimos anos, uma aparente redescoberta desta paisagem do rio Pinheiros, indicando formas de sua apropriação por atores do capital e do poder público.

Uma porção significativa de sua extensão urbana margeia a "nova centralidade" econômica da cidade, a região entre a Av. Brigadeiro Faria Lima e a Av. Eng. Luiz Carlos Berrini. Palco de processos de espetacularização urbana, a dinâmica de transformação da paisagem que o compreende é acelerada. Dado seu atual contexto urbanístico, as margens do rio Pinheiros passam, já há duas décadas, por uma “revitalização" iniciada pela requalificação das estações de trem da CPTM. Hoje, parte de suas margens dispõe de projeto de manutenção paisagístico e contêm um proto- parque linear acompanhando uma ciclovia, inaugurada em 2010, hoje com mais de $21 \mathrm{~km}$ de extensão. A apropriação paisagística de suas margens desvela um projeto de rio urbano implantado sobre um espaço que, por décadas, esteve à margem de qualquer interesse e envolvimento afetivo em relação à sua paisagem, por parte dos cidadãos e do capital estatal e privado. 
A planície aluvial que caracterizava a várzea do rio Pinheiros, que compreendia os antigos rios Grande e Jurubatuba, teve seu processo de metamorfose iniciado nos anos 1920, com um projeto de infraestrutura e saneamento baseado na canalização do leito sinuoso do rio e na reversão de seu fluxo, para captar as águas derivadas da bacia do rio Tietê, no intuito de gerar energia hidroelétrica no Complexo da Serra da Cia. Light, como uma alternativa à crise energética dos anos 1920. Até então, tratava-se de uma região de várzea com vinte quilômetros de extensão por aproximadamente um de largura, quando inundada. Com baixos índices de ocupação e pequenos bairros residenciais, referencial histórico da pesca e da navegação, a região era marginalizada em relação às colinas paulistanas. Após décadas de obras de saneamento e "recuperação" da várzea promovidas pela Cia. City e pela Light, as margens do rio Pinheiros passam a ser urbanizadas e sua canalização se dá integralmente.

Em 1970, é inaugurada a Av. Nações Unidas, conhecida como Marginal Pinheiros, juntamente à Av. Eng. Luís Carlos Berrini, dando início ao que se caracteriza como o processo de poluição e degradação total das águas do rio e de transformação radical da paisagem. É a partir daí, então, que se inicia a história do rio Pinheiros tal como o conhecemos.

\section{Por que paisagem?}

O projeto de pesquisa acadêmica surgiu da observação da presença do rio Pinheiros na cidade de São Paulo e da relação intrínseca que tem tal presença com uma qualidade específica do espaço que se configura às suas margens. A princípio, dizemos desta qualidade ser relativa a uma "paisagem" do rio Pinheiros, mas, no entanto, o emprego da 
2. BARTALINI, V. A paisagem em arquitetura e urbanismo: remontar às nascentes como opção metodológica -in: PAISAGEM E AMBIENTE:

Ensaios - . 32 - Fauusp : São Paulo, 2013 p. 67 - 82 ideia de "paisagem" para uma porção relativamente pequena do território urbano parece algo um tanto desproporcional, visto que o rio configura, ao longo de sua extensão, uma série de espaços com qualidades distintas. Falar em uma única "paisagem do rio Pinheiros” soa, em um primeiro momento, algo reducionista. A paisagem que se desdobra às suas margens contém várias outras paisagens, nas quais se expressam qualidades das várias porções da cidade por onde o rio passa. Uma série de questões, já de início, se colocam: o rio Pinheiros configura uma paisagem? Ou seria ele apenas a parte de uma paisagem maior da cidade, que o abarca?

Em primeiro lugar, para situar o leitor em relação ao emprego da palavra "paisagem" em nosso texto, cabe afirmar que optamos por aceitar que, hoje em dia, a ideia de paisagem compreende diversos significados, e é empregada em uma multiplicidade de contextos e disciplinas do conhecimento, assumindo uma pluralidade de sentidos, como meio ambiente, território, entre outros. Nesse sentido, Bartalini ${ }^{2}$ (2013, p. 69) nos mostra que, no meio acadêmico, a diluição da acepção da palavra "paisagem” em alguma medida se afastou de sua vinculação à estética e à arte. Essa vinculação é, contudo, a que norteia a acepção que predomina em nossa pesquisa, uma vez que nossa investigação se dá majoritariamente no campo das artes visuais.

Entretanto, assumimos a possibilidade de um significado mais abrangente do termo, que inclua, na sua dimensão estética, uma componente geográfica, enquanto território ou espacialidade. As possíveis confusões que podem ocorrer referem-se a casos em que o termo paisagem é empregado com o sentido de imagem ou obra de arte em que se representa uma paisagem, que pode se sobrepor ao sentido da paisagem "real", a da experiência, o espaço físico por onde nos deslocamos e que, por vezes, se mostra como paisagem. Orienta-se o leitor para que, nesses casos, prossiga a leitura consciente de que uma e outra coisa podem se confundir, entendendo que essa sobreposição é bem-vinda e que, inclusive, 
ela participa de uma discussão que é relevante para nossa pesquisa: está implícito nestas sobreposições de sentido que a ideia de paisagem existe como algo que ocorre simultaneamente entre categorias da entidade física do espaço ou do ambiente, da experiência estética (no sentido de aisthesis), e a da cultura ou imaginário que, por sua vez, se funda na experiência sensível e afetiva do espaço, mediada pela memória e pela psique.

Uma vez assumido este sentido de paisagem, que contempla a reciprocidade entre exterioridades e interioridades dos sujeitos, da cultura e do mundo físico, estabelece-se um campo de pressupostos conceituais que nos possibilita transitar com alguma desenvoltura entre a história da arte e a experiência estética da paisagem do rio Pinheiros. Com a mediação de suas representações gráficas e pictóricas, produzidas como séries de vistas em sequências espaço-temporais, podemos examinar em que medida aquilo que se mostra visualmente nas imagens produzidas, tem rebatimento na história das paisagens. Uma vez que a intenção destas imagens protagonizadas pelo rio é, por assim dizer, "realista" ou "naturalista", no sentido de uma descrição fiel dos fatos e da estrutura visual dessa paisagem, buscaremos entender até que ponto esta descrição é prenhe de sentidos históricos que vão além de sua própria presença física, $s$ indicando-nos associações visuais com outras paisagens e outros rios.

Assim, a aposta nessa empreitada é a de que pelo fazer artístico, mais especificamente do desenho e da pintura, é possível acessar alguma universalidade na relação que temos com as paisagens, especificamente na medida em que ela se dá na presença do rio. No caso, a hipótese é a de que, pela via da representação visual de sua paisagem, nosso rio empírico se ligaria ao rio conceitual, simbólico, mítico e metafórico. Do mesmo modo, a paisagem que seria a forma particular de expressão visual do Pinheiros nos ensinaria a ver novamente as paisagens das tradições históricas; de uma narrativa histórica construída segundo esse modo de abordagem, chegaríamos a uma caracterização do contexto atual 
da paisagem como representação visual e das principais motivações e desafios que a ela se colocam.

Uma vez que a pesquisa parte da produção de trabalhos artísticos e que foi a partir de sua produção que se colocaram as questões teóricas sobre a paisagem e o rio, decidiu-se por construir a dissertação de modo fiel a essa lógica de trabalho. $O$ texto é construído em dois estratos que, em alternância, caminham paralelamente: um primeiro, em que se desenvolve uma narrativa sequencial em torno do exame das imagens produzidas, buscando trazer à tona questóes relevantes às escolhas formais e de conteúdo no decurso deste depoimento poético sobre o rio; e um segundo, em que se desenvolve uma narrativa sobre a história das paisagens na arte, amparada em um diálogo com as questões colocadas pela produção das imagens.

Este formato não contém a intenção, vale dizer, de estabelecer uma hierarquia de importância entre prática e teoria. A precedência de uma narrativa visual sobre o rio Pinheiros sobre uma narrativa vinculada à história das paisagens na arte é, simplesmente, a ordem lógica que guia a pesquisa e a dissertação, e que proporciona a enunciação de questões a serem colocadas da prática para a teoria. Isso não quer dizer que não haja influência recíproca entre as narrativas paralelas, e que a teoria não coloque questões objetivas à prática. Mas é, sobretudo, a fidelidade ao fato de que foram as motivações artísticas que colocaram a paisagem como objeto teórico em evidência, a ponto de que, em determinado momento, se constatasse que a pesquisa prática, diante do rio Pinheiros, já continha uma forte componente teórica. A intenção que temos é de que ambos os estratos se retroalimentem, e a estrutura da dissertação, ainda que siga um fio condutor linear, é a da circularidade, alternando sempre a um momento de leitura de nossa produção, um momento de teoria e história da arte. Propõe-se assim, que haja um verdadeiro diálogo entre 
3.MERLEAU-PONTY, Fenomenologia da Percepção. WMF Martins Fontes, 2011.

4. CLARK, K. Paisagem na Arte. Lisboa : Ulisseia, 1961. os dois campos de narrativas, o que não significa que o tempo narrativo e a quantidade de informações presente em cada um deles seja igual; assim como não quer dizer que não possa haver independência e autonomia entre eles.

O último ponto a ser explicitado diz respeito à base de sustentação teórica que guia ambas as narrativas. Há um estilo de pensamento que orienta nossas reflexões sobre a paisagem empírica e a prática da representação da paisagem, cujo aporte teórico é fundado na filosofia de Maurice Merleau-Ponty, especialmente no que diz respeito à percep̧̧ão como modo de contato do ser com o mundo. As reflexões sobre a visão, a pintura e a linguagem, tecidas no interior da fenomenologia ${ }^{3}$ deste filósofo, se mostram especialmente férteis às nossas discussões. Segundo elas é possível estabelecer relações entre o fazer do desenho e da pintura, na medida em que correspondem à percepção como um modo pré-objetivo de se situar diante do mundo visto, de modo a que o desenho, que só pode se expressar pela linguagem de sua própria visibilidade, pode ser um análogo da fenomenologia: como ela, o desenho “[...] repõe as essências na existência, e não pensa que se possa compreender o homem e o mundo de outra maneira senão a partir de sua facticidade." (MERLEAU-PONTY, 2011, p .1) O desenho e a pintura se relacionam com o mundo sem que o sentido e o significado das coisas se coloque à frente daquilo que elas comunicam à nossa percepção visual, de modo que podemos, assim, compreender “[...] o mundo que está sempre "ali”, antes da reflexão, como uma presença inalienável”, segundo um "contato ingênuo com o mundo", para reinterpretá-lo em termos de traços, manchas e cores, sem que qualquer julgamento de outra ordem se interponha nessa relação.

Quanto à história das paisagens, apoiaremo-nos majoritariamente na obra Paisagem na Arte ${ }^{4}$, do historiador e crítico britânico Kenneth Clark, que é a obra mas importante até atualidade na abordagem na história da paisagem como assunto da pintura e 
das artes gráficas. Clark foi capaz de traçar um desenvolvimento histórico abrangente da paisagem na arte ocidental, segundo diversas atitudes artísticas cujas identidades específicas não se explicam somente de modo cronológico, mas, sim, por afinidades visuais dentro de contextos históricos mais amplos. É por isso que as categorias que ele coloca, como a "paisagem dos fatos", a "paisagem dos símbolos"e a "paisagem ideal" são modos de olhar a paisagem cuja expressão não está restrita a um determinado século, mas, em alguma medida, se mostra evidente em diversos períodos e contextos da história da arte.

Postos estes principais aspectos da dissertação, prosseguimos a um breve resumo da estrutura da dissertação. A sequência que se anuncia para o desenvolvimento dos assuntos abordados e objetivos pretendidos é a seguinte:

1. Em um primeiro capítulo, após a reflexão sobre o rio enquanto símbolo mítico, com ênfase na questão da memória, partindo da leitura de uma série de gravuras, privilegia-se o exame da paisagem em sua origem histórica, no intuito de identificar uma possível relação originária entre as paisagens e os rios, para que se possa visualizar uma estrutura visual de articulação entre eles. Tal articulação é, inequivocamente, um lugar-comum da ideia visual que se tem de paisagem. E, por isso, para que possamos nos aprofundar na investigação sobre a presença do rio Pinheiros em sua correspondente paisagem, busca-se estabelecer nexos entre a figura do rio e sua função na estrutura espacial das paisagens, principalmente no que toca à profundidade e ao movimento visual.

Tal estrutura é, por sua vez, relacionada a um momento inicial da paisagem enquanto narrativa autônoma nas pinturas, no Renascimento. Será importante discutir o quanto este momento inicial se confunde com o surgimento da perspectiva geométrica, e relativizar tal associação, uma vez que, como nos mostra Clark, este "nascimento" da pais- 
agem se caracteriza mais por transformações internas de uma linguagem presente no final da Idade Média do que por uma influência do advento da perspectiva científica.

2. O segundo capítulo se inicia com a apresentação da primeira série de gravuras sobre as margens do rio Pinheiros, segundo a qual se discute a característica percepção de horizontalidade, o panorama das paisagens, e a relação dessa horizontalidade com o céu. Também serão abordadas as questões da luminosidade celeste e sua relação com os detalhes e pormenores da paisagem, a presença das pontes como motivo paisagístico, assim como a linearidade do rio. A linearidade, como veremos, engendra uma especial sensação de continuidade, que se coaduna com a intenção de se registrar um percurso, o que corresponde a uma pretensão cartográfica de se criar um plano de representação em que a localização geográfica das paisagens seja levada em conta.

As questões colocadas na série de gravuras nos conduzirão ao episódio da história da paisagem em que o registro factual da luz e do espaço se coloca em evidência, segundo a categoria de "paisagem dos fatos"de Clark, e a do "impulso cartográfico" de Alpers, que correspondem à arte do Norte da Europa no renascimento.

3. No terceiro capítulo, é apresentada uma série de pinturas e gravuras referentes a uma imersão em um dos braços do rio Pinheiros, o córrego Pirajuçara. Como veremos nas imagens, há uma outra estrutura visual colocada nas imagens, cuja razão de ser está na própria forma física do córrego, que é diferente da do rio.

As paisagens do córrego Pirajuçara, por sua vez, nos remetem às paisagens do período barroco e romântico da pintura, correspondendo àquilo que Clark chama de "paisagens ideais" e de "visão natural". Veremos que, se a paisagem ideal, a exemplo de pintores como Poussin e Claude Lorrain, se caracteriza por uma linguagem de ordenação do espaço 
pictórico, o naturalismo romântico de um Constable, apesar de se utilizar de todo o repertório de um vocabulário do barroco, caminha para uma maior dramaticidade e dá vazão a uma maior expressividade e liberdade, já indicando as paisagens da pintura moderna, ao impressionismos e ao expressionismo. Nesse ínterim, será abordada a questão da unidade luminosa e a questão da atmosfera, que é tão cara ao pensamento estético das paisagens.

4. O quarto e último capítulo se inicia com uma nova série de gravuras e pinturas da paisagem do rio Pinheiros, em que se evidencia um novo olhar, mais frontal e pictórico, em que se vê um maior sentido de ordenação e disposição compositiva na representação das margens do rio. Essa última série traz maior ênfase na horizontalidade e nas características narrativas de figuras típicas dessa paisagem marginal.

O gancho com a história da paisagem na arte se dá pela questão da disposição ordenada de elementos no plano pictórico, que nos remete à busca de ordenação e de uma harmonia paralela à da natureza no momento inaugural do modernismo. A exemplo de Cézanne e Seurat, veremos como a pintura de paisagens se afasta do naturalismo e da relação com a sensação visual impressionista, de modo que deixa de ser um gênero absoluto como o fora no século XIX, tornando-se pouco relevante para a arte das vanguardas históricas.

Se a abstração tornou a figuração da paisagem um assunto indigno das aspirações artísticas modernas, na segunda metade do século XX pintores abstracionistas passam a se reaver com questões presentes na pintura de paisagem em meio ao expressionismo abstrato, e analisamos a obra de Diebenkorn, que fez da paisagem um motivo de sua pintura, de modo a superar a dicotomia entre figuração e abstração.

Em direção a um desfecho da narrativa histórica, nos aproximando do contexto da paisagem contemporânea, introduzimos um breve exemplo da crítica conceitual à rep- 
resentação da paisagem colocada na land art com ênfase na obra de Smithson no que ela toca à questão da degradação de um rio urbano, que se associa com a nossa investigação sobre o rio Pinheiros.

O capítulo se encerra com o exemplo contemporâneo da obra de Paulo Pasta, que se filia à tradição abstracionista de Diebenkorn, no que toca ao seu gosto pela paisagem. Veremos, segundo seu exemplo, como a relação contemporânea da pintura com a paisagem assimilou as lições da arte abstrata, de uma nova componente histórica e mnemônica. 



\section{CAPíTULO 1}




\section{O rio, as margens e a memória} da paisagem

1. ANDRADE, Carlos Drummond de,A Rosa do Povo. São Paulo : Cia. das Letras, 2012 pp. 71-73 Trecho do poema Residuo, de Carlos Drummond de Andrade.

2. TORRANO, Jaa. O mundo como função de musas in; HESÍODO, Teogonia : A origem dos deuses / Hesíodo : estudo e tradução de Jaa Torrano. São Paulo : Iluminuras, 2007.
Este trabalho se origina a partir de uma xilogravura em que se representa o rio Lete (ou Letes), o "rio do esquecimento" situado no Hades da mitologia grega. Segundo Jaa Torrano, tradutor e autor da introdução da Teogonia, de Hesíodo, em grego, Lete, ou Léthê, literalmente "esquecimento" ou “ocultação", significa o oposto de a-létheia, que se-

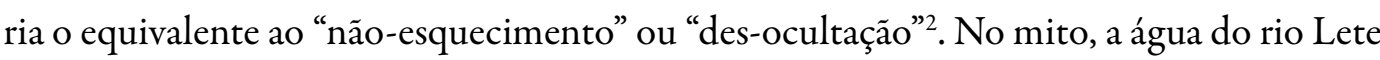
proporciona o completo esquecimento das vidas passadas àquele que a tocar ou beber, e há versões em que existe também o rio Mnémosyne, o "rio da memória”. Após a morte, caberia à alma escolher de qual deles deveria beber. A água do primeiro proporcionaria o completo esquecimento, e a do segundo, a onisciência, a memória total. Na Teogonia, esposaram-se de Zeus Leto e Memória, e é esta última, “[...] que, em cada mo(vi)mento de cada ente, decide entre o ocultamento do Oblívio e a luz da Presença." (TORRANO, 2007, p. 67) Em sua introdução ao poema, Jaa Torrano nos explica que "A força de presentificação e descobrimento que põe os seres e fatos à luz da presença é a mesma força de ocultação e encobrimento que os subtrai à luz e à ausência.”( 2007, p. 24)

A literatura não precisa muito bem a localização do rio mítico no Hades, assim como há dubiedades quanto ao seu nome, Letes ou Âmeles. Presente em diversos momentos na mitologia e retomado posteriormente por autores diversos na filosofia e na literatura ocidental, no Livro X da República Platão evoca a função do rio Lete, que participa na preparação das almas para a reencarnação, limpando-as das memórias anteriores para que retornem renovadas à vida. No diálogo platônico, essa menção ao rio 


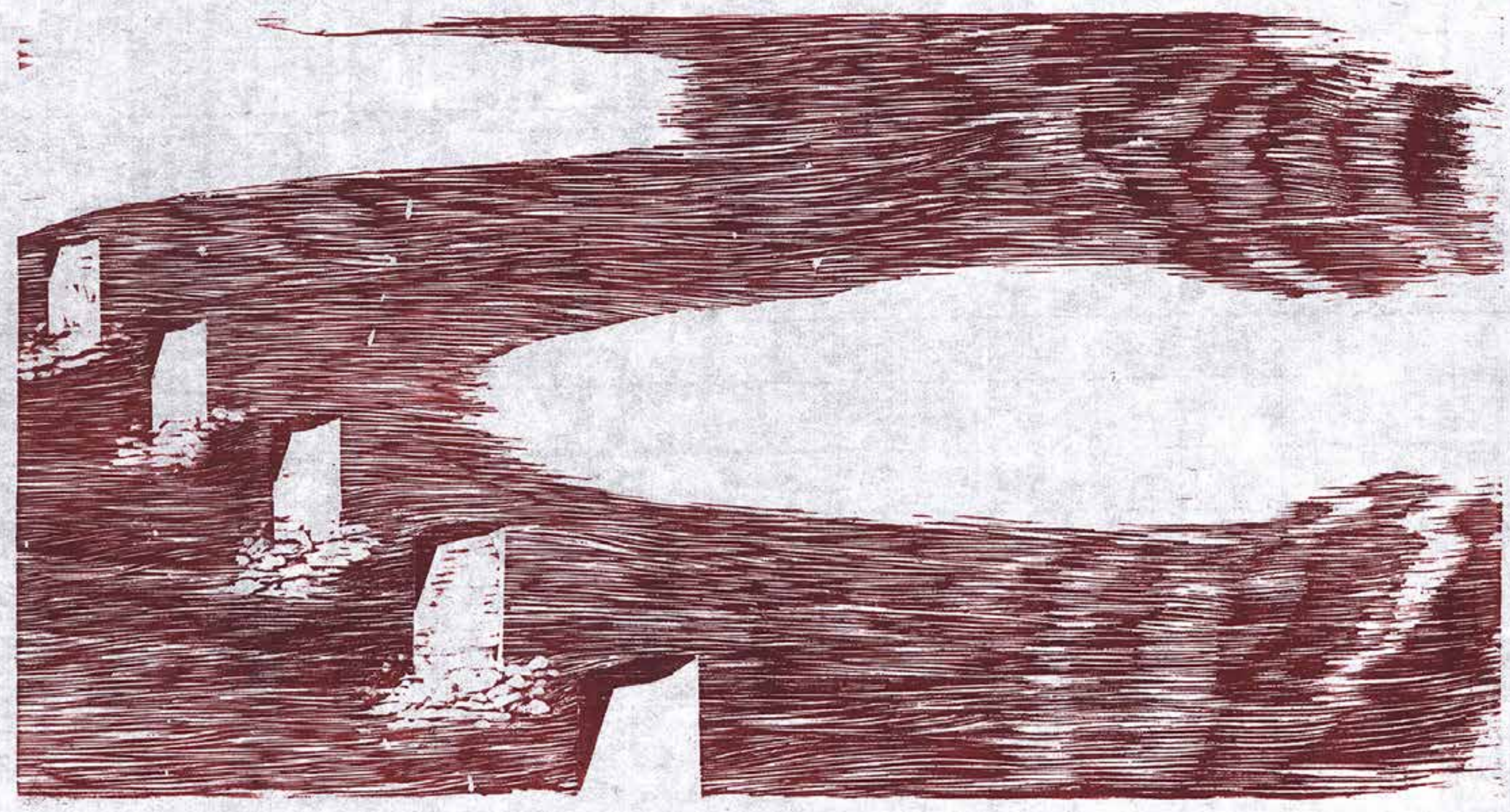


3. PLATÃO, A República. Introdução, tradução e notas de Maria Helena da Rocha Pereira. São Paulo: Fundação Calouste Gulbenkian, 2005. p.496 4. De modo fortuito, surgiu da proposta por uma publicação estudantil da FAUUSP cujo tema era a memória. do esquecimento se dá quando Sócrates, dialogando com Glauco, conta-lhe o famoso mito de Er, em que aparecem as planícies de Letes, em que se situa o rio Âmeles ("sem cuidados") “[...] cujas águas nenhum vaso pode conservar. Todas [as almas] são forçadas a beber uma certa quantidade desta água, mas aquelas a quem a reflexão não salvaguarda bebem mais do que a medida. Enquanto se bebe, esquece-se tudo." 3

Diante da rica tradição de significados que permeiam a imagem poética evocada por Drummond em seu poema, a gravura que abre este capítulo busca expressar uma reflexão sobre a possibilidade desse total esquecimento. À esquerda, vemos o sentido do leito do rio, que corre passando por elementos verticais, que representam comportas abertas, inspiradas nas barragens. A passagem da água pelas comportas baliza a lavagem, o esquecimento e a limpeza das almas. Já à direita na imagem, vemos aquela água que não passou pelas comportas, e que parece se mover no sentido oposto, conformando figuras em movimento, como corpos residuais e espectrais, as almas perdidas que resistem ao devir do esquecimento. São os fantasmas da memória, que sobrevivem à passagem do tempo, e que constituem parte da "natureza residual" para a qual apontaremos nas paisagens de rio, e o sentido metafórico que se atribui a ele no trabalho.

A passagem do poema Resíduo de Drummond acima citada serviu de motivo à criação da imagem ${ }^{4}$. Sua relação poética com a pesquisa sobre a paisagem do rio não poderia ser mais rica e direta, e deu sentido a um olhar específico para a paisagem, impulsionando todo o seu desenvolvimento posterior.

Nesse desenvolvimento, do rio teórico se chega ao rio empírico, no caso o rio Pinheiros, em São Paulo, que tornou-se objeto de uma pesquisa visual. Os resultados dessa pesquisa visual detonam uma série de questões sobre a paisagem como representação visual e com a presença da cidade em torno do rio, e a literatura e a história da paisagem nos servem de apoio à discussão de tais questões. 
Entre outras manifestações, a paisagem-natureza na cidade de São Paulo é indissociável da presença das águas, como condição fundamental à geografia e à história da cidade: o rebaixamento e a constante supressão dos rios e córregos acarretam manifestações de algo do "natural" em São Paulo. A presença dos rios ocultos aflora em inundações, em situações singulares da infraestrutura urbana, onde o residual se mostra como ausência de um projeto de cidade. A presença das águas é visível na vegetação que se “joga” às suas margens, nas bocas de lobo do esgotamento. Nos grandes rios urbanos de São Paulo conflui toda essa materialidade residual e oculta da cidade, que aflora na superfície do rio como uma torrente de rejeitos de toda espécie. Em suas margens se nota, contudo, também uma grande "produtividade" de ordem natural: espécies resilientes da flora e da fauna urbana a habitam especificamente por toda sua extensão.

\section{Entre margens, a travessia}

Não é possível separar o rio de suas margens. À exceção de rios de proporções marítimas, é raro imaginar uma paisagem de rio em que não se veja uma das margens. Desse modo, a "paisagem do rio" costuma significar a "paisagem da margem do rio", uma vez que não somos seres do mundo aquático, e sim seres"ribeirinhos”, pois quase sempre escolhemos viver próximos à margem dos rios.

A condição existencial à beira do rio, na margem, carrega o inevitável embate com uma negatividade, que é a do espaço cindido pela presença do corpo d'água, separando um lado do outro lado, uma porção de espaço de outra. A princípio, a outra margem nega nossa existência e liberdade, pois ela é o oposto do espaço por nós habitado. Não podemos estar dos dois lados ao mesmo tempo, e por isso a outra margem exerce em nós uma atração, um interesse simplesmente em função de sua alteridade. Olhar para a outra mar- 
Na página seguinte [imagem 3], Travessia. 2013. Xilogravura sobre papel japonês, 43 x $51 \mathrm{~cm}$. gem é o desejo de movimento, de atravessar algo que resiste a ser atravessado, e de possuir um espaço que se nega à nossa presença física.

A ideia da travessia nos serve também para refletir sobre a paisagem do rio como aquela em que reinam os direcionamentos e forças das águas. O rio como obstáculo coloca a possibilidade (ou não) da travessia, nos solicitando uma descida ao nível de seu leito. Para cruzar o rio, é necessário molhar os pés, pisar a lama do fundo. Na xilogravura acima, estão figuradas as almas que caminham, amontoadas, sobre as ondas da água do rio Letes. Uma forma pontiaguda,como uma lança, que vem da direita para a esquerda, , no topo da imagem, aponta para um sentido: será ele o sentido do esquecimento? Ou é o sentido da travessia em direção à outra margem? O embate com a corrente pode trazer tanto a potência de nos deixarmos levar por ela, quanto a de resistir à correnteza para chegar à outra margem. Mas o que nos aguarda na outra margem?

A travessia nos serve de metáfora da passagem, correspondendo à lavagem da alma para que esta possa retornar à vida. Trata-se de passar de uma margem do rio à outra, lavarse na água do esquecimento para, livre do peso da memória, poder emergir novamente. Há um apelo otimista, positivo, uma sede de vida que nos atrai à outra margem, assim como um receio, o peso que nos ancora na margem em que nos situamos. Desse modo, o rio simboliza a eterna renovação da vida levada ao longo de seu leito, mas é parte de sua natureza abrigar também a vida em sua morbidade latente, evocando o eterno retorno do mesmo: a dupla potência da memória no rio se expressa na constante renovação de suas águas,uma matéria que não deixa de ser a mesma que sempre foi: a água, ser dúctil, elemento indiviso e universal, se dissolve, evapora, e volta a se condensar. O que faz com que, de certo modo, a mesma água que nasce límpida nas nascentes evapora da transpiração dos corpos, e torna a chover sobre as plantações. Como disse Gaston Bachelard: "O rio não precisa ser nosso; a água não precisa ser nossa. A água anônima conhece todos os meus 


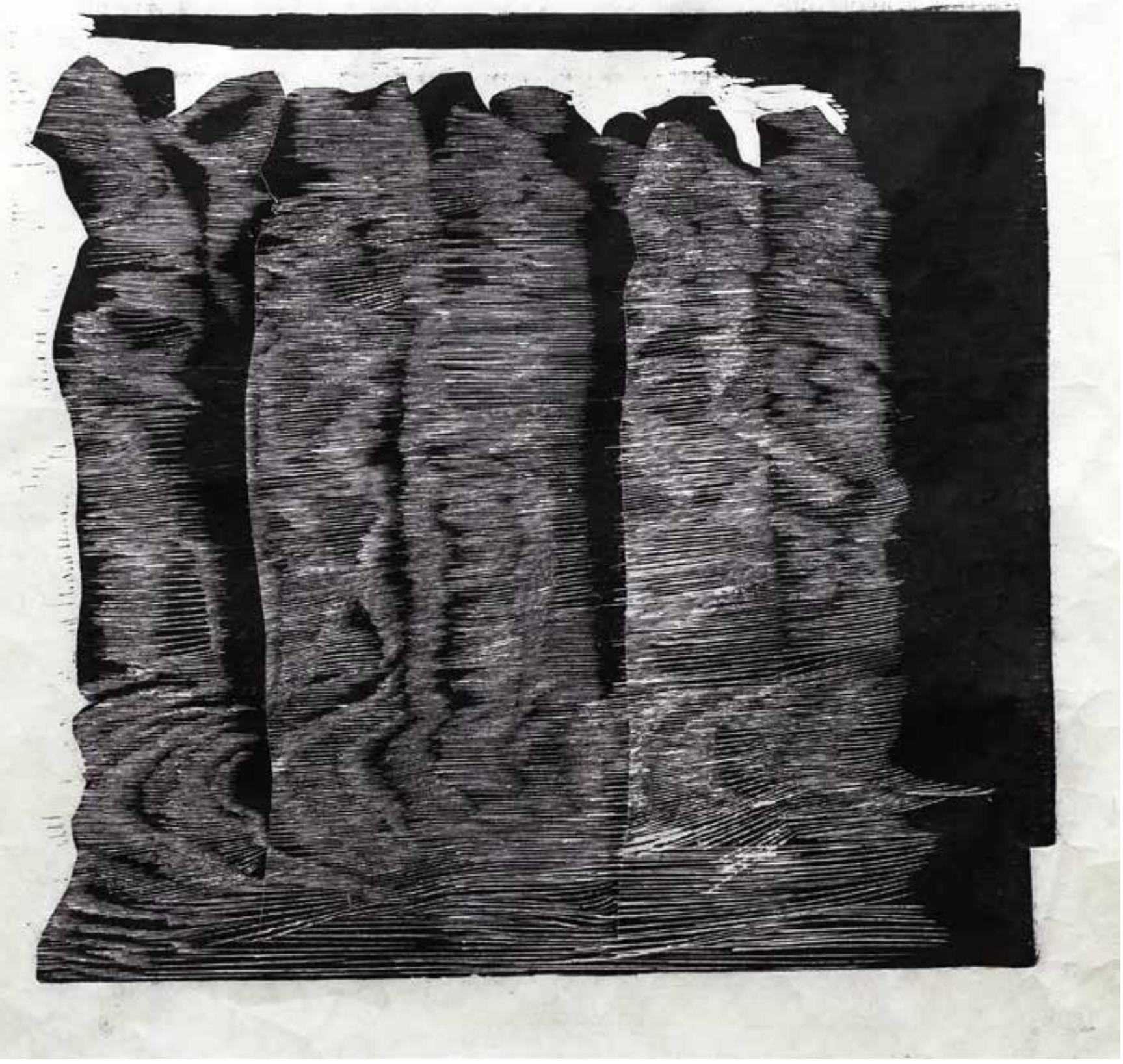


5. BACHELARD, G. $L$ 'eau et les rêves. Essai sur l'imagination de la matiere Apud SCHAMA, S. Paisagem e Memória. São Paulo, Cia. das Letras, 1996, p. 250

Na página seguinte [imagem 4], Horizonte de eventos, 2014. Xilogravura sobre papel jornal $39 \times 9 \mathrm{~cm}$. segredos. E a mesma lembrança jorra de cada fonte."

"Subvivendo", almas que não se deixam levar pela água do esquecimento habitam toda a extensão do rio, decantando-se, agarrando-se às margens e a pedaços de vida que viajam pela correnteza, tornando-se parte do corpo d'água. O solo do rio é um acúmulo de resíduos e detritos ocasionado pela passagem das águas, que limpam e carregam toda a existência. Sobre a matéria morta, a renovação se faz pela corrente das águas, e assim pode a vida aspirar ao seu estado nascente.

$O$ rio exerce, pelas águas, uma força de atração implacável, e toda extensão de suas margens está, em potencial, fadada à erosão, a depositar-se no seu leito. A correnteza draga toda a matéria que a toca, e o rio se faz ponto de confluência e convergência de todas as secreções e dejetos do mundo. Tudo aquilo que se perdeu, as coisas desgarradas e despejadas são imperiosa e generosamente acolhidas pela água dos rios.

Portanto, o espaço configurado junto ao rio é um espaço de instabilidades, desprotegido das intempéries e sujeito à inundação e à impermanência. A água tende a destruir lenta e constantemente a matéria que toca, e o rio corrói e dilapida as superfícies minerais que acaricia. É, assim, o rio um berço da entropia, onde a materialidade promiscuamente se dissolve, se misturando ao caldo das reminiscências.

A imagem na página seguinte [4] nos evoca justamente esse poder de atração exercido pelas águas do rio, que suga sua envoltória em direção à indiferenciação. As margens do rio são espaços em iminente erosão, e, ao mesmo tempo, o conformam. Uma força invisível exercida pela água as suga o tempo todo, ainda que lentamente. A imagem sugere formas, corpos e construções do universo humano, sendo engolidas e se atirando, desfazendo-se em direção à convergência central que divide os dois lados da composição. Poderia aludir a um ralo, uma boca de lobo, à embocadura das galerias ocultas dos rios que, como buracos negros, pontuam as paisagens fluviais das cidades. Trata-se de uma 


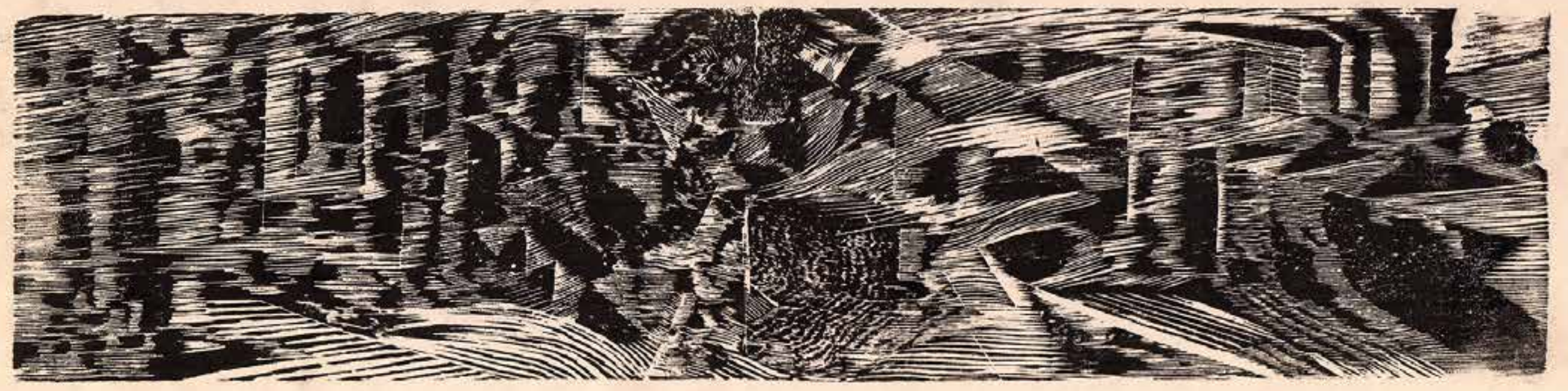


6. HATOUM, Milton. O rio é a minha memória. Texto publicado em francês na "Magazine-Air France", dezembro, 2018, trad. Michel Riaudel. Publicado online pelo autor em 12/02/2019 e acessado em http://facebook.com/

7. RYCKMANS , P. As anotaç̃es sobre pintura do Monge Abóbora-Amarga. Campinas, Ed. Unicamp, 2010. Em nota, o tradutor de Shitao explica que o termo traduzido por paisagem, shanchuan, é um binômio que literalmente significa "as montanhas e os rios". "Mas que o leitor não se esqueça: 1) a palavra "paisagem" é expressa em chinês pela união dialética de dois complementares opostos: "montanhas e rios"; 2) a expressão "montanhas e rios" não é disjunmiltonhatoumescritor/ em 21/02/2019. tiva:sugere em chinês uma noção de "paisagem".

imagem da potência renovadora do rio, que carrega o mundo consigo, sempre em direção à renovação. Há o célebre aforismo de Heráclito que diz: "Não se pode entrar duas vezes no mesmo rio”. A partir de tal fragmento, não poderiam ser mais oportunas as palavras do ribeirinho amazonense Milton Hatoum acerca do elemento poético do rio e de suas margens como lugar de tensões entre forças e do movimento da memória:

“[...] Esse e outros aforismos são ensinamentos preciosos sobre a vida. As duas margens simbolizam a estabilidade e a instabilidade, uma tensão entre forças opostas.

O rio é uma metáfora da nossa existência: a vida como movimento incessante das águas. No fluxo constante entre duas margens há remansos que refletem serenidade, e correntezas fortes que traduzem tensão. $\mathrm{O}$ repouso e a inquietação. $\mathrm{O}$ mesmo e o seu contrário. $[\ldots]$

Todos os rios, reais ou imaginários, desaguam no rio perene da infância. Suas águas correm entre as margens da vida, que se estreitam sutilmente com a passagem do tempo. Mas o rio é cósmico, atemporal: morre e renasce a cada instante, agoniza e se fertiliza, percorre o céu, a terra e o mundo subterrâneo.

O rio é a minha memória."

\section{1}

\section{A água e o relevo}

A princípio, entende-se aqui a água como elemento central à ideia de paisagem. A paisagem pictórica quase sempre traz a presença de um rio ou corpo d’água. Em mandarim, traduz-se paisagem por "rios e montanhas" nos escritos do pintor e pensador chinês Shitao (ou Daozhi). A ideia chinesa de paisagem corresponde à relação entre dois elementos necessariamente complementares. A imbricação entre relevo e água já estava explícita na ideia de paisagem desde o seu nascedouro, permeando tanto a história dos jardins e do paisagismo, quanto sua dimensão poética e representacional. 
Segundo Franco Panzini ${ }^{8}$, a ideia de paisagem guarda, em sua ancestralidade, uma relação de ordem cósmica com o mundo. Às características morfológicas do território eram associados significados transcendentais, como, por exemplo, as montanhas foram associadas à "[...] residência das divindades e os ambientes elevados como sítios privilegiados na relação com o sobrenatural.”(PANZINI, 2000. p. 41) Mas por detrás dessa busca pelas alturas estava a necessidade material da agricultura: era necessária a comunicação com as autoridades celestes responsáveis pela chuva.Como símbolos da sacralidade da montanha, temos as formas das pirâmides e zigurates. Nesse sentido, a montanha e a água imbricamse numa relação "paisagística” primitiva com o mundo, que só foi possível à medida que o ser humano se tornou agricultor e sedentário.

De modo geral, pode-se dizer que a relação entre a terra e a água define o fundamento da paisagem enquanto projeto e artefato humano. A história da inventividade humana sobre o espaço se confunde com a necessidade de se levar a água de uma parte a outra do território. É a história dos grandes empreendimentos da engenharia hidráulica. Se o rio não está dado naturalmente, é necessário criá-lo artificialmente, puxar braços de água, seja como galerias subterrâneas ou aquedutos, expandindo o terreno cultivável, para que se possa inventar o jardim, a horta ou pomar.

Nesse sentido, poderíamos indicar, com relação à paisagem do rio, uma componente fundamental do artifício, da instrumentalização da natureza enquanto elemento água. No entanto, tal ideia sobre uma artificialidade da paisagem parece problemática quando confrontada à tradicional noção de paisagem como natureza intacta, que existe fora do habitat humano, virgem e intocada pela civilização. A paisagem humana surge à medida em que o ser humano transforma radicalmente o ambiente, e a natureza agrária se sobrepõe à morfologia natural. 
9. RITTER, Joachim. Paisagem - função estética na sociedade moderna, p.63 - in: Paisagemtextos - vol.3. trad. e org. Vladimir Bartalini. São Paulo: FAUUSP, 2013. ROGER, Alain. Court Traité du Paysage. Paris, Gallimard, 1997.

10. Cf. RYCKMANS ,P., 2010 op cit.. p. 18 presença dos corpos d'água, é de se pensar que estava já na gênese da vida urbana algo que viria a ser uma “invenção" da paisagem. Sendo assim, a paisagem não cumpriria tanto a função de uma reconciliação da vida urbana moderna com a natureza sob os termos da fruição estética e nostálgica, como nos sugere Joachim Ritter ${ }^{9}$. A paisagem seria, antes, a primeira representação de uma natureza que acolhe a comunidade humana, em que a comunidade passa a transformar seu território e a construir a cidade. É fruto de uma primeira síntese formal, a idealização de uma intenção do homem para com a sua situação no mundo em que vive, e das relações entre sua vida e uma determinada terra.

Não cabe à nossa pesquisa, no entanto, rastrear as primeiras representações da paisagem; o que se pretende indicar é a presença de uma concepção de paisagem que se expressa na relação entre as cidades e os corpos d'água. Podemos intuir , assim, que, se no renascimento europeu a paisagem toma sua forma conhecida até hoje, essa forma tem origem em uma representação cultural que remonta ao nascimento das cidades, às planícies aluviais dos rios Tigre, Eufrates e do Nilo. É dessa herança milenar que vem o imaginário das paisagens, que já estava plenamente desenvolvido enquanto representação visual no mundo anterior ao renascimento. O que sobrou de tal desenvolvimento está presente em diversos exemplos das artes grega, romana e chinesa.

A concepção da paisagem como "rios e montanhas", expressa por Shitao no século XVII, por outro lado, se inscreve na continuidade de uma tradição de artistas que desenhavam paisagens segundo a observação, desde a dinastia Tang (entre séculos VII $\mathrm{X})$. O mais antigo tratado teórico sobre a pintura chinesa que se conhece data do século $I V^{10}$. É difícil afirmar desde quando, e com qual intensidade, a arte paisagística chinesa teria sido vista e influenciado a arte europeia, mas é provável que circularam estampas de gravuras chinesas pela Europa durante a Idade Média, a partir da difusão do papel, cuja invenção na China data de meados do século II d.C., por meio da Rota da Seda. 
No âmbito desta pesquisa, a distância cultural e o difícil acesso à bibliografia sobre pintura chinesa nos impedem de estudar com algum aprofundamento esta tradição. Portanto, nos restringiremos à referência a Shitao, com a consciência das limitações de leitura que se colocam, e amparando-nos na extensa pesquisa organizada nas notas do tradutor. A utilidade de seu texto vem, no nosso caso, do caráter filosófico e poético de seu conteúdo, que nos dá insumos para exercitar e ensaiar reflexões sobre qualidades das imagens de paisagem.

A paisagem como "rios e montanhas" é fruto de uma tradição milenar do pensamento zen-budista. Os rios e montanhas são a expressão de um binário de forças complementares e opostas que, assim como a noção de "Universo", que se traduz literalmente no binômio "Céu e Terra" (qiankun) (2010, p. 91), está fundada na relação dinâmica e necessária entre o rio e o relevo; a água e a pedra se entrosam como duas faces de uma mesma existência mineral.

Deste modo, a ideia chinesa de "rios e montanhas" traz o imaginário da paisagem para um terreno anterior à paisagem como presença da vegetação e da vida animal. A paisagem está basicamente na relação da água com a rocha ou a terra, e desta relação brotam, em um segundo momento, a vida vegetal e animal.

Não se trata aqui de buscar uma essência mineral da paisagem, mas sim de concebê-la na sua construção imagética: se é possível colocar tal paralelo, posso dizer que a água desenha sobre a rocha as linhas do relevo, conformando-se à tectônica do corpo geológico da paisagem; assim como desenhamos as linhas de força e movimento sobre um suporte que tem, ele próprio, uma forma que determina e condiciona a qualidade da composição visual e a forma das linhas. Tudo aquilo que vai além dos rios e montanhas participa necessariamente na paisagem, mas o traçado, em seu caráter estrutural, é de uma natureza mineral. Tudo o mais na paisagem se assenta sobre "rios e montanhas", segundo Shitao. Nas palavras do pintor e pensador: 
"A Paisagem expressa a forma e o impulso do Universo.

No interior da Paisagem,

o vento e a chuva, a obscuridade e a claridade constituem o humor atmosférico;

a dispersão ou o agrupamento, a profundidade e a distância constituem a organização

esquemática;

verticais e horizontais, depressões e relevos constituem o ritmo;

sombras e luz, espessura e fluidez constituem a tensão espiritual;

rios e nuvens, em sua conjunção e dispersão, constituem a ligação

o contraste entre as reentrâncias e as saliências constitui a alternância entre a ação e o

recolhimento." (2010, pp. 89-90)

A ideia do rio e do relevo como elementos básicos da forma "paisagem" é aqui analisada no sentido de uma primeira aproximação com as paisagens do rio Pinheiros, cujas imagens são objeto desse trabalho, e nas quais nos dedicamos especificamente aos aspectos de sua "organização esquemática" e de seu "ritmo". Os parâmetros da linguagem da paisagem colocados pelos versos de Shitao serão, em nosso estudo, emprestados numa abordagem livre, à medida em que se mostrem úteis à análise das imagens.

O modo como o autor expõe tais noções sobre a forma das paisagens suscita um desejo por racionalização esquemática, que, muito provavelmente, incorreria em simplificações e aproximações grosseiras em relação ao significado desta passagem de seu tratado. Entretanto, arrisquemo-nos a um exercício de interpretação: poderíamos agrupar tais parâmetros de Shitao em três diferentes grupos, de forma a que nos sirvam como categorias para analisar as imagens de paisagem em níveis de abordagem distintos:

Nível 1. a - "Ligação" - conjunção x dispersão (de rios e nuvens)

b - "Ritmo" - verticais x horizontais (depressões e relevos) 


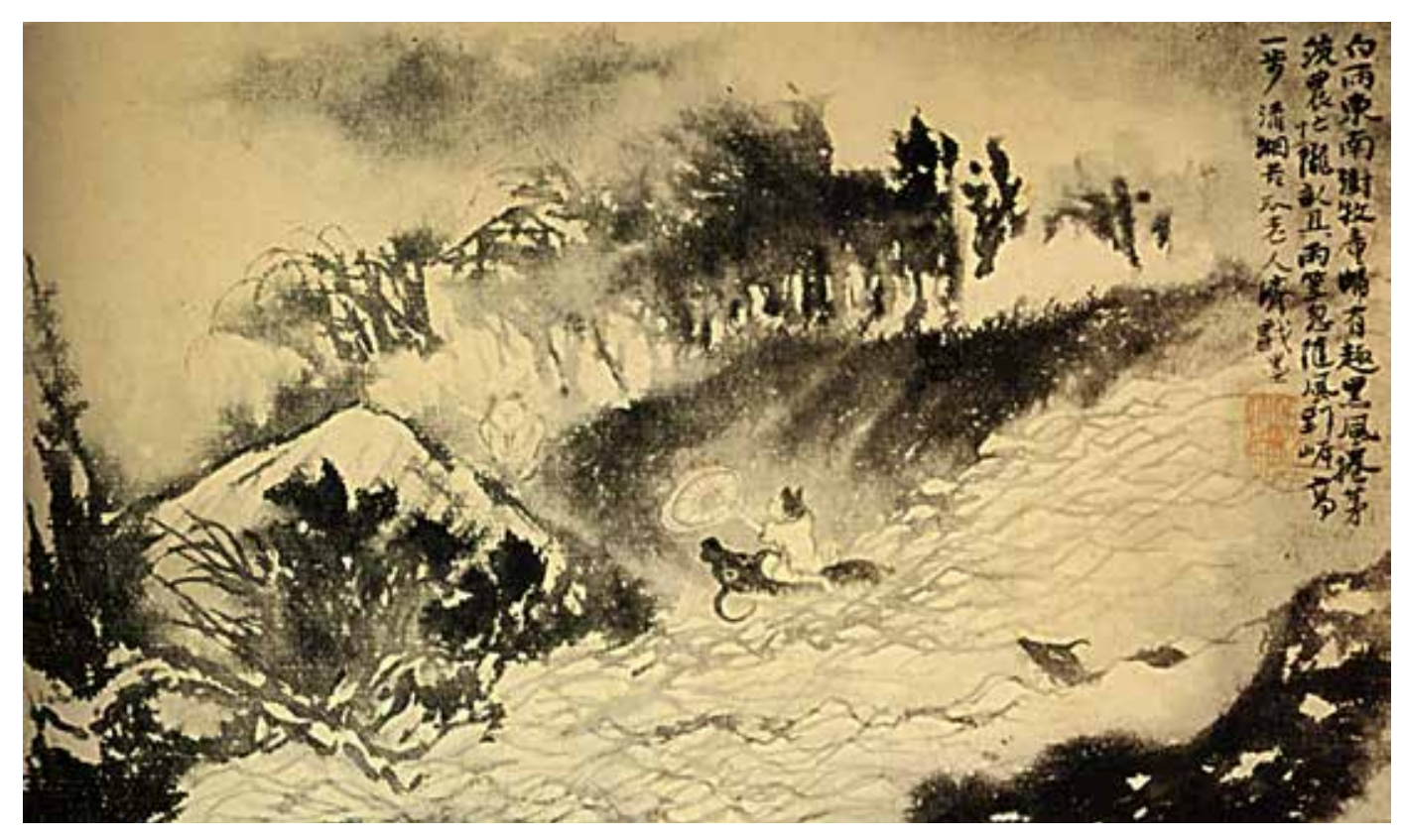

Ao lado [imagem 5], Shitao, The Crosses Torrent, 1699 , nanquim sobre papel, $24.5 \times 38 \mathrm{~cm}$.

Fonte:https://www.wikiart.org/pt/shitao/the-crosses-torrent-1699

Não será o caso de empregar literalmente este esquema - que pelos motivos já mencionados, decerto não corresponderia a uma leitura definitiva do texto de Shitao como método de análise para as paisagens apresentadas. Mas, se associássemos tais categorias a um ideal prático do desenho ou da pintura de paisagem, é interessante apontar como 
elas reproduzem aspectos distintos do processo pictórico ou gráfico, o que não quer dizer que s ocorram em uma determinada ordem ou hierarquia de funções. São aspectos da linguagem que se entrecruzam e cujo equilíbrio varia em cada paisagem, mas que se referem a dados que existem simultaneamente na paisagem empírica e na paisagem representada.

Em um primeiro nível, temos qualidades correspondentes a noções estruturais de movimento e repouso visual, que poderiam ser associadas aos fundamentos compositivos do desenho de uma paisagem; como a organização fundamental de planos e linhas horizontais e sua relação dinâmica com a verticalidade; e a relação espacial entre o céu e a água no plano de representação, expressa poeticamente pela ideia de "ligação".

No segundo nível, estaríamos entre o âmbito "esquemático" da ordenação composicional e do desenho, em um momento de maior aproximação aos pormenores ou fatos da paisagem; criam-se profundidade e relações espaciais específicas; definem-se contrastes entre a forma que se retrai e a que se expande.

O terceiro nível reúne qualidades de ordem mais “imaterial”, referentes às sutilezas da luz e da sombra, na medida em que ela cria a "tensão espiritual", assim como a qualidade "atmosférica"; trata-se da unidade mais impalpável, que se dissolve pela paisagem e que confere qualidades ao ar, mais ou menos nebulosas, ou diáfanas e etéreas ao espaço. Ao longo da pesquisa, será possível estabelecer nexos entre esse modo de conceber as qualidades visuais das paisagens e aquilo que se analisa e critica sobre as obras.

Como veremos, é sintomático dos valores ocidentais o fato de que parecem ser sempre as qualidades atmosféricas e de luz, as referentes ao nosso "terceiro nível", aquelas que são mais valorizadas e correspondentes ao que se considera como a qualidade propriamente artística da pintura de paisagem. Há uma hierarquia de valores estabelecida na crítica de arte que tende a se pautar pelo percurso hegeliano da história da arte, rumo à desmaterialização que se reproduz em relação às paisagens, na medida em que se atribui 
maior interesse à obra quanto mais ela se afasta das formas definidas, dos detalhes do desenho "linear", e se exprime em termos mais "pictóricos", como a mancha, aluminosidade e a cor atmosférica; à luz e à atmosfera é conferido um estatuto mais próximo ao da ideia.

1.2

\section{$O$ rio como narrativa das paisagens}

11. CAUQUELIN, A. A invenção da paisagem. São Paulo : Martins, 2007

12. CLARK, K. Paisagem na Arte. Lisboa : Ed. Ulisseia, 1961
Canonizada como uma das pinturas de paisagem inaugurais da história da arte ocidental, A Tempestade de Giorgione traz também o leito do riacho dividindo um cenário misto de natureza e urbanidade, onde se anuncia ao fundo um céu tempestuoso. Segundo Anne Cauquelin ${ }^{11}$, essa seria uma das primeiras pinturas sem um tema narrativo claro. As personagens não têm uma relação explícita e parecem quase "sobrar" diante da paisagem, que dá o tom do quadro. Desde 1530, Vasari e muitos outros analisaram o quadro, sem conseguir reconstruir sua literalidade e desvelar seu mistério. Há hipóteses diversas sobre o tema e a narrativa, mas nelas o quadro, que é quase só paisagem, se perde.

Para Kenneth Clark ${ }^{12}$, a Tempestade de Giorgione seria um exemplo clássico das paisagens ideais, e Clark arrisca esboçar uma estrutura compositiva fundamental às paisagens arcádicas:

"De ambos os lados se encontram massas escuras de árvores e rochas, como os bastidores de um cenário teatral, que deixam livre o centro do quadro. Até as figuras que se integram perfeitamente na paisagem colocam-se por vezes a um lado. O céu e a distância tomam o espaço central. Este tipo de composição viria a ser básico em Claude." (CLARK, 1961, p.82) 
Ao lado [imagem 6], A Tempestade, c.1505, óleo sobre tela, $82 \times 73 \mathrm{~cm}$, Giorgione, Galleriadell'Accademia, Veneza, Itália.

Fonte:https://www.wikiart.org/pt/giorgione/a-tempestade- 1505

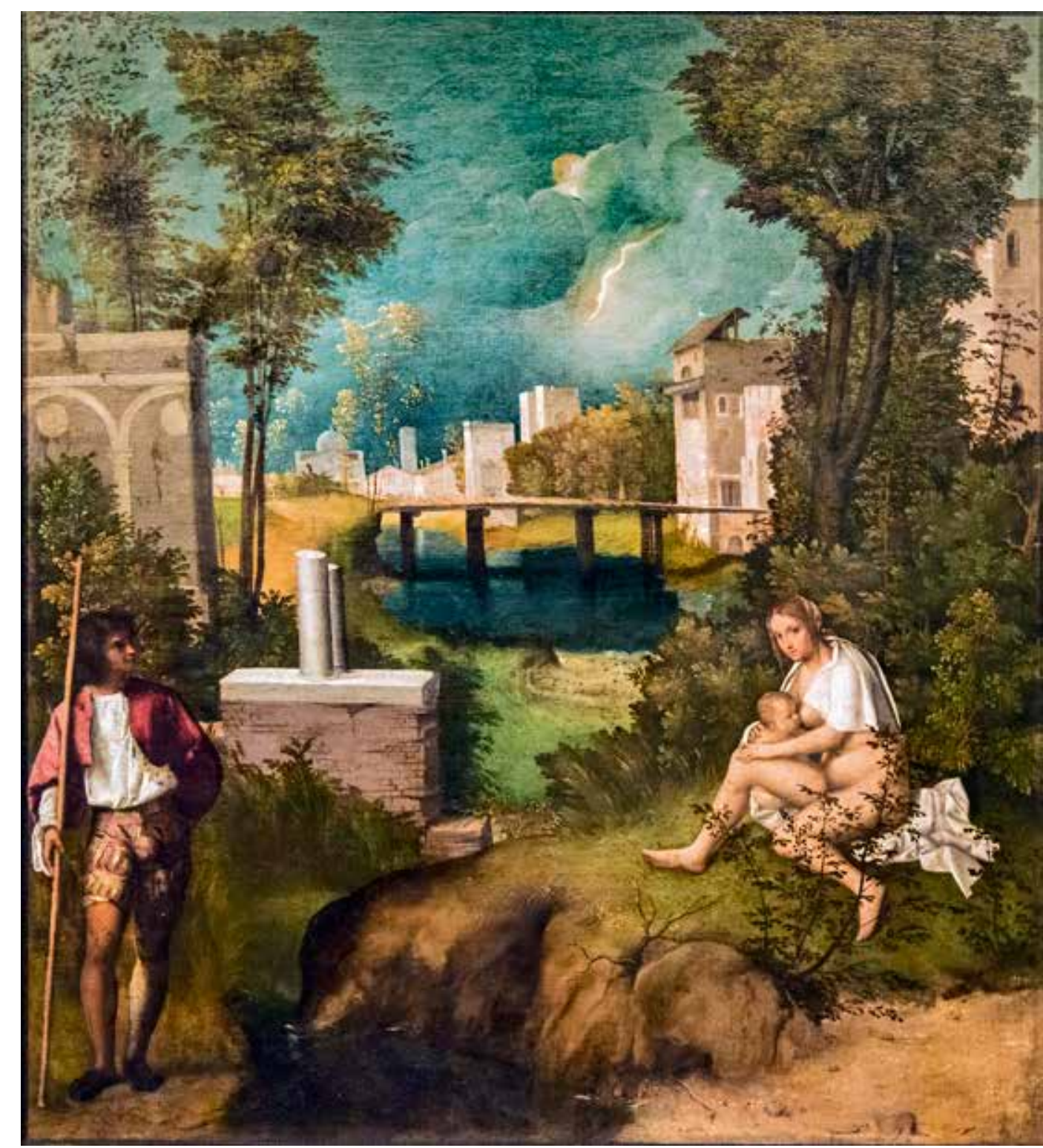


Mas arrisquemo-nos aqui a analisar a imagem sob um outro viés. O que nos interessa em termos visuais, no momento, é que ela é uma paisagem conformada ao redor de um rio. O olho a percorre, plano a plano, seguindo o rio, visitando a ponte que encerra o segundo plano, e o rio segue à esquerda diante das edificações que se veem na margem direita. Contra ou a favor da corrente, é o rio que permite que nos movimentemos pela paisagem até encontrarmos a tempestade. As personagens assentam-se como a base de pilares que sustentam o pórtico encerrado de lado a lado pela ponte. $\mathrm{O}$ olhar pouco se detém sobre as figuras, pois a paisagem ao longo do rio, a cidade iluminada em contraste com a escuridão do céu, exerce uma maior atração. $\mathrm{O}$ vértice da pirâmide composicional coincide com a lua, mas ela compete com um raio que corta as nuvens, quase alinhado com a aresta de uma outra pirâmide menor. É o cume luminoso da imagem.

O que queremos destacar é que a relação do rio com suas margens, assim como sua transposição pela ponte, é o que estrutura a imagem em termos de horizontalidade e verticalidade, ditando ao olhar o ritmo e o sentido de movimento. Da mesma forma, é também segundo o rio que a percepção de profundidade e distância se constrói, e, se o céu é o plano mais profundo da imagem, ele só não toca o rio pela mediação feita pela ponte, cuja sombra sobre o rio divide ao meio a porção inferior da imagem da porção superior.

$\mathrm{O}$ rio exerce, imperioso, um poder narrativo sobre qualquer imagem. Como se lê em Simon Schama (1996), no mundo ocidental, a linearidade do rio confunde-se com a linearidade da história, com a ideia de começo e fim, de nascimento e morte, e os "despotismos hidráulicos" permeiam todos os grandes impérios, simbolizando potência e a prosperidade. "A relação entre sacrifício, propiciação e abundância fluvial parece ter ocorrido em todas as grandes culturas da Antiguidade que giravam em torno de rios."(SCHAMA, 1996, p. 263)

Ainda que haja inúmeras paisagens sem a presença de rios, mares ou corpos 
13. DARDEL, E. O Homem e a Terra - natureza da realidade geográfica - São Paulo: Perspectiva, 2015 d água na história da arte, é possível que constituam exceção, e em muitas delas é possível indicar algum outro elemento que poderia aludir metafórica ou alegoricamente ao rio, ou substituí-lo como elemento formal, uma vez que a ausência do corpo d'água acarreta infertilidade e aridez, e o espaço não aponta para outro plano da materialidade que ele próprio, tornando-se confinado à sua identidade seca, sem um prolongamento para fora de si. Eric Dardel nos aponta de antemão: "Lá onde não existe água, o espaço tem algo de incompleto, de anormal: o deserto, a superfície árida dos platôs calcários, sugerem naturalmente a ideia de morte." 13 Para suprir essa falta, o mundo antropizado cria seus equivalentes ao rio, que dão algum direcionamento ao espaço.

A exemplo dos "bulevares fluviais", Schama nos mostra que a cultura latina criou a tradição que associa os rios aos "fluxos de poder e tempo, carregando impérios desde a nascente até a extensa foz. [...]As culturas clássicas do Oriente e do Oriente Próximo viam os rios sagrados como elos temporais e topográficos. O Ocidente romano, de longa data, via os rios como estradas que podiam se tornar retas." (1996, p. 266) O rio é, portanto, o direcionamento, eixo de movimento e devir das paisagens. Nas cidades, pode muito bem estar oculto sob a forma de uma rua ou avenida, e em boa parte dos casos, tal ocultamento é literal. No campo, o rio pode ser visto sob a forma de uma trilha ou estrada, e, nas vistas panorâmicas de paisagens montanhosas, se o rio não é visível, ele está implícito como a sombra meandrante dos fundos de vale.

O poder narrativo do rio insere-se em uma tradição que culmina em imagens no Renascimento, em que o mundo que se desdobra atrás das personagens e heróis das ações humanas é mais importante que elas próprias. $\mathrm{O}$ rio toma as rédeas do tempo presente na imagem, e é a paisagem, ela própria, seu desdobramento narrativo. Ver segundo a margem do rio nos serve, assim, como uma metáfora da própria questão da paisagem no ocidente, que, como sugere Cauquelin (2007), coincide com a questão da pintura e da perspectiva. 
Pois diante do rio, marca-se uma descontinuidade entre o meu ponto de vista e a margem oposta que observo, e monta-se uma cena balizada pela força da linha do rio. A linha, por si só, "instala" planos perspectivos, épuras da paisagem diante de quem o contempla.

No contexto artístico em que se enquadra o exemplo de Giorgione, o rio pode ser lido como símbolo de uma narratividade que se transfere, na pintura, das figuras para o espaço em que elas se articulam. No entanto, tal contexto não se verifica no Ocidente antes do Renascimento, e ele se deve à presença de uma nova atitude em relação à paisagem, que irá nos levar à sua autonomia em relação ao relato histórico ou mítico. As origens de tal transformação são, comumente, associadas à mentalidade renascentista em relação direta com o surgimento da perspectiva, que teria tornado possível conceber a representação da profundidade ilusionista no espaço, de modo que o rio visto em profundidade, como o de Giorgione, seria facilmente explicado. Mas esta seria uma explicação demasiado simplória, e a história da arte nos mostra o conhecimento da perspectiva muito anteriormente à Renascença, como mostraremos adiante. 
1.3

\section{A questão da perspectiva}

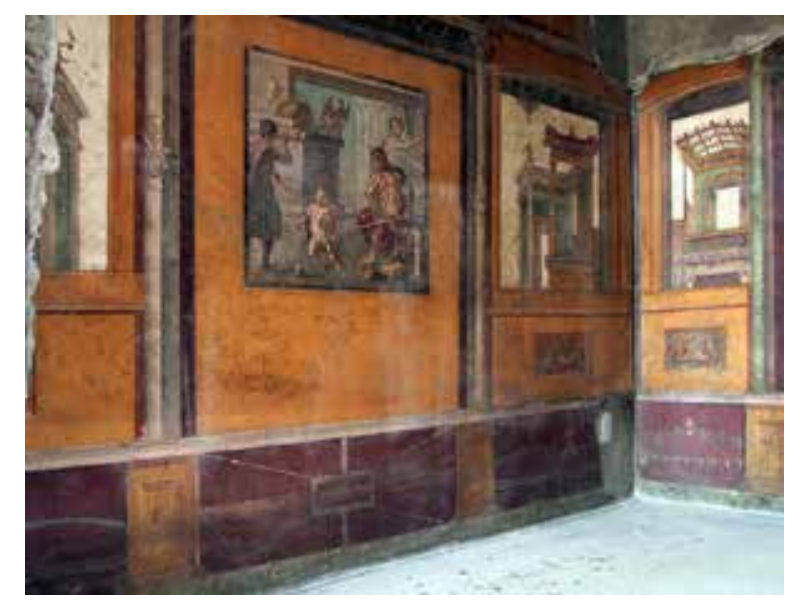

Acima [imagem 7], Autor desconhecido. Afrescos da Casa dei Vettii, Século I, Pompéia

Fonte:http://viagens.hi7.co/domus--villa--insulae---a-vida-cotidiana-de--uma-cidade-romana---$57 \mathrm{aac} 8 \mathrm{ffb} 3722 . \mathrm{html}$

14. FLORIÊNSKI, P. A perspectiva inversa - São Paulo : Ed. 34, 2012.
Em grande medida, a autonomia da paisagem corresponde à autonomia da pintura em relação ao discurso narrativo lógico que a encampa. Considera-se na história da arte que as paisagens perspécticas do século I, nas vilas de Pompéia, eram "cenas de ilusão", dirigidas à razão pela verossimilhança: "Perspectivas de perspectivas: as janelas pintadas se abrem para outras janelas", nos diz Cauquelin. Para a autora, nelas ainda a questão da pintura não estava posta: a paisagem era ainda história ou narração, pois nelas não se “[...] abre a natureza à visão por meio de si mesma. Não é de dupla face. [...] Não enfrenta a relação com a realidade, mas com o texto mitológico." (2007, p.80) Não se tratava então de ver a pintura, mas de ilustrar o relato de maneira convincente, razoável e verossímil. "É a razão que vê, não o olho."( 2007, p.81)

$\mathrm{Na}$ Renascença, para Cauquelin, teria havido uma inversão de prioridades: faz-se da técnica pictórica o "pedagogo de uma ordenação":

“[...]Parece que existe uma ordem da visão, distinta das construções mentais pelas quais estaríamos certos até mesmo da realidade.[...] Quadro, forma, tela, como se queira, armadilha onde se cativa a natureza. Doravante, podemos recorrer ao "mostrar" da pintura para organizar as aparências, e a razão, que nada mais pode, dobra-se a esse imperativo, recupera o atraso e justifica o conjunto. São as leis da perspectiva, ela dirá. Esse "mostrar o que se vê" faz nascer a paisagem, a separação do simples ambiente lógico.” (2007, p.81)

Diante da "retórica" própria das aparências ordenadas das paisagens, o conjunto de símbolos de razão discursiva de uma história passam para um segundo plano.

A esse respeito, Pavel Floriênski ${ }^{14}$ endossa a opinião de Cauquelin, definindo os afrescos de Pompéia, Alexandria e da cultura helênica em geral, como "[...] esse barroco do mundo antigo, encarregado de tarefas puramente ilusionistas, [que] aspirava justamente a ludibriar o espectador que se supunha praticamente imóvel." (FLORIÊNSKI, 2012. 
p. 42) A intenção deste autor, no entanto, é sustentar que as leis da perspectiva já eram plenamente conhecidas pelos antigos, e de que seu uso seria deliberado de acordo com as necessidades das imagens. Ela não era aplicada tanto às obras de arte "puras", as pinturas de ícones religiosos e cenas mitológicas, possuindo maior presença em imagens "menos valiosas", utilitárias, exercendo uma função cênica. Sua ocorrência diminui e aumenta em determinadas épocas, sendo pouco vista na Idade Média e voltando com grande ímpeto no renascimento. Para o autor, a perspectiva era usada com fins decorativos:

\footnotetext{
"Merece uma grande atenção o notável fato de que, a partir desta paisagem ilusionista, estendem-se os fios de conexão à arquitetura do palco greco-romano. A raiz da perspectiva é o teatro, não só pelas razões histórico-técnicas de que foi o teatro que pela primeira vez exigiu a perspectiva, mas também em virtude de uma motivação mais profunda: a teatralidade da representação perspéctica do mundo. Nisso consiste a percepção do mundo obtida com um esforço mínimo, privada da sensação de realidade e da consciência de responsabilidade, para a qual a vida é só um espetáculo e nunca um ato de coragem. E por esse motivo - voltando a Pompéia - é difícil procurar nessas pinturas autênticas obras de arte pura." (2012, p. 44)
}

Há que se notar o contexto histórico e sociopolítico soviético em que se inscreve Floriênski, uma vez que ele defende uma "pintura pura", correspondente a um ideal modernista de arte. Floriênski quer relativizar um senso comum de que não se sabia perspectiva na Idade Média, nos dizendo que, ao contrário, o valor estético da obra de um pintor se mede na medida em que ele se afasta das regras da perspectiva, da arte dos simulacros, e cria sua linguagem sintética do mundo visível.

Mas o que nos interessa nessa discussão é apontar um contexto histórico, em que a perspectiva passa a mediar uma nova percepção de mundo que seria correlata à autonomização da paisagem como gênero artístico. Talvez essa correlação seja verdadeira, mas no que ela tem de verdadeiro, pode-se desconfiar da sua causalidade, pois, como nos mostra 
Floriênski, há uma certa "mitificação" em torno do nascimento da perspectiva na renascença, assim como sua personalização em torno dos italianos Brunelleschi, Alberti, entre outros.

A perspectiva é uma construção cultural cuja origem remonta aos antigos e cujo desenvolvimento se dá até hoje. Nossa reflexão aqui intenciona, no entanto, apontar em que termos as transformações da paisagem na renascença se fundam menos no advento da perspectiva como ordenação da realidade sensível, do que no desenvolvimento de uma linguagem paisagística da pintura. A emancipação da paisagem ocorre em paralelo ao avanço técnico da perspectiva científica, e não em razão dela. A perspectiva como articulação entre o olhar e a razão não é suficiente para explicar os diversos modos de relação entre imagens e realidade tangenciados pela paisagem no olhar renascentista.

Se, como afirma Cauquelin, a perspectiva seria uma forma de exibir o "vínculo existente entre o pensamento e a visão", se é ela que "[...] tece, entre os elementos armazenados no saber, a tela de uma visão sintética"(2007, p.85), ela se realiza como uma passagem que reconcilia dois mundos, o da visão e o da razão, preservando a relativa independência de cada um. É este caráter de passagem que nos interessa, justamente por acolher ambos os mundos de um suposto dualismo entre o "ver" e o "saber ter visto":

"Uma constante revolução agita o par compreender-ver. Compreendo porque vejo, e à medida que vejo, mas só vejo por meio e com o auxílio do que compreendo que é preciso ver naquilo que vejo." (id., p. 85)

A passagem exemplifica com grande precisão aquilo que buscamos identificar na paisagem: uma relação estruturante entre a linguagem de representação e a percepção do fato paisagístico. Vemos paisagens porque vimos pinturas de paisagem, mas as paisagens não são só pinturas; há um vínculo complexo entre a natureza e sua representação, que 
15. ROSA, João G. Primeiras estórias. Rio de Janei-

ro : J. Olympio. 1977, pp 27-32. pode ser vislumbrado sob os termos de um não-dualismo entre intelecto e sensibilidade. Em referência a Wittgenstein, a reflexão da autora retoma o conceito de "maravilha da Natureza", sobre o qual a arte se alicerça:

"[...] é por meio da arte que digo o que vejo que devo ver na natureza. E o que vejo dessa maneira é paisagem. É preciso ver, ver diante de si, ver o que é "dado" a distância. Vê-lo como um todo e relacionar esse todo com a natureza. [...] Questão da construção de uma autonomia da pintura, de seu distanciamento do relato, de sua passagem para o lado daquilo que ela mostra: a paisagem". (Id, p.87)

Numa leitura poética e um tanto literal deste trecho, remete-se novamente à imagem da beira do rio, onde a potência da passagem - de um lado ao outro, ou de uma margem a outra - nos auxilia a refletir sobre como nascem as pinturas de paisagem: da conjugação entre mundos de interioridade e exterioridade, um terceiro mundo surge. Mas ele não ocupa um espaço ou o outro, ele está em ambos, sem que se possa ver seus limites, pois se dá nos vaivens desta passagem de si a si, o território das paisagens.

Ora, mas se a paisagem não está nem lá nem cá, se ela é o meio, o próprio ato de uma travessia, tampouco ela é o rio. O rio é então o território do eterno trânsito, habitado por tudo aquilo que não passou de um lado a outro. A depender do fluxo das águas, aquele e aquilo que vive no meio do rio realiza talvez uma outra passagem, em direção à foz, à redenção nas águas salobras dos deltas a perder de vista. Mas o caminho é incerto, e somente os corpos e espíritos mais leves, lisos e desancorados costumam realizar essa outra passagem. Aos mais pesados é mais provável a dissolução, desintegração e decantação no curso do rio até o mar.

Seria o destino desta outra passagem, o de deixar-se levar pela correnteza, a "terceira margem do rio" de que nos fala o conto homônimo ${ }^{15}$ de Guimarães Rosa? Vista da beira do rio, a figura que boia na canoa pode aludir às almas que não realizam a passagem 
e se perdem no rio do esquecimento, os espectros da memória. Se estar na paisagem é, como quer Erwin Straus, "estar perdido", perder seu lugar definido no mundo objetivo ${ }^{16}$, a personagem de Rosa, o homem na canoa, tão longe quanto perto da margem do rio, que nem vai embora, nem volta, passou a viver na paisagem.

\section{4}

\section{A autonomia da paisagem: do jardim do Éden ao mundo da percepção}

A presença do rio como símbolo e componente fundamental à ideia de paisagem nos levou à tentativa de compreender em que medida ele se articula com o nascimento da paisagem moderna, enquanto gênero artístico autônomo. Se o rio não é uma condição básica à paisagem, ele não deixa de estar intimamente ligado a uma certa qualidade das paisagens, que é a de introduzir no espaço e no mundo representado uma alteridade radical, uma fenda no relevo, que gera instabilidade e equilíbrio perante a força tectônica da terra e da rocha da montanha. O rio é a força da singularidade, que instaura o movimento em meio ao que é estático, e que tece a ligação cósmica da terra com o céu na linha do horizonte. $\mathrm{O}$ direcionamento indicado pelo rio nas paisagens é análogo à busca pela distância, desviando nossa atenção dos elementos próximos e conduzindo o olhar em direção ao longe e ao desconhecido. É nesse sentido que a perspectiva poderia estar intimamente ligada a esse modo de aparecer transitivo dos rios, mas tal relação se prova superficial quando nos conscientizamos da contingência da perspectiva em relação a um universo muito mais rico e complexo, que envolve a paisagem.

Em meio às transformações dos costumes da sociedade ocidental, ocorreu um movimento cultural em direção à expressão autônoma do espaço e dos elementos da natureza, propício ao desenvolvimento de um novo modo de encarar e comunicar a ex- 


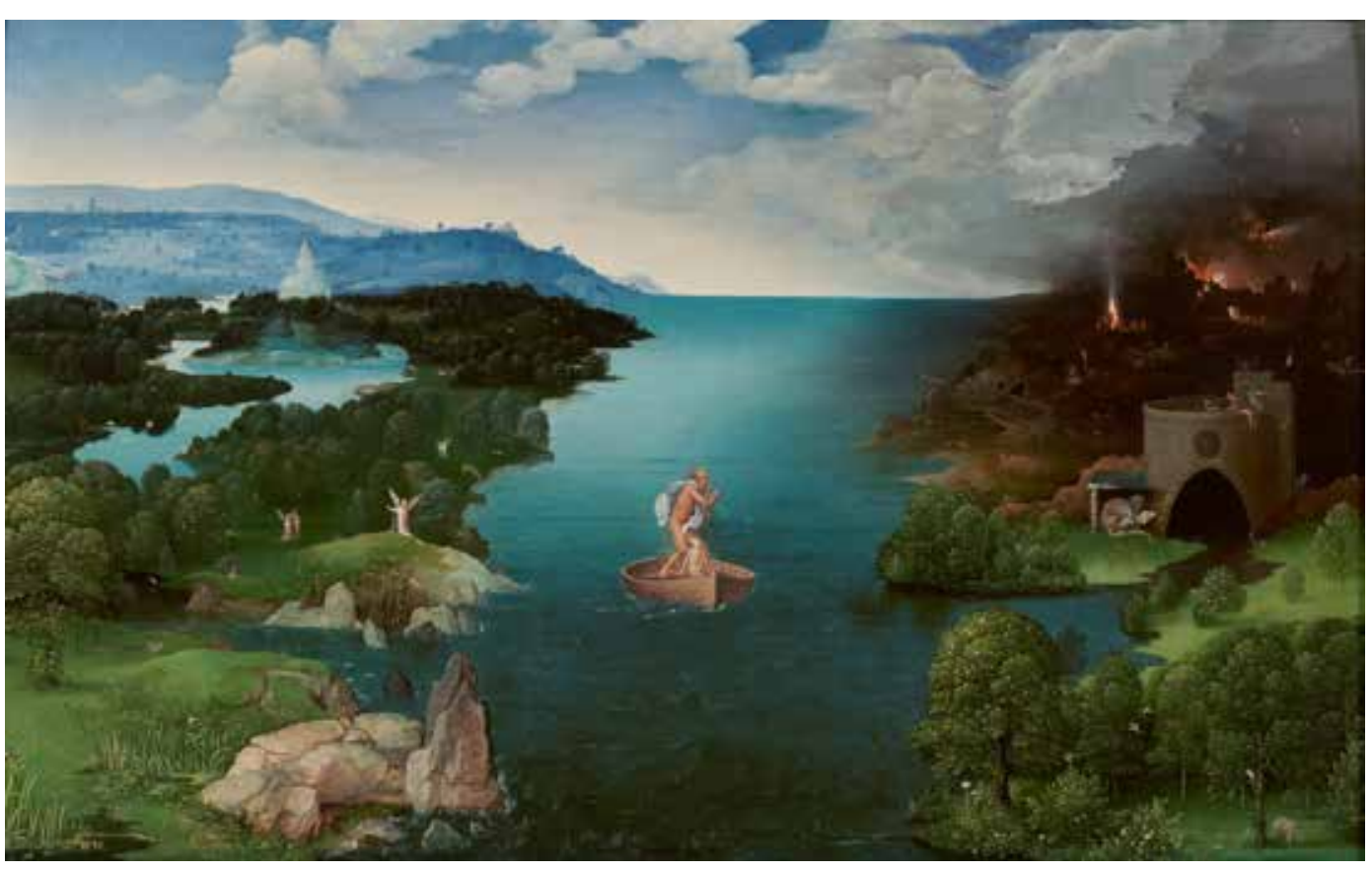

Ao lado [imagem 8],Joachim Patinir, Überfahrt in die Unterwelt. c. 1515-1524, óleo s/ madeira. $64 \mathrm{x}$ $103 \mathrm{~cm}$. Museo Del Prado, Madri.

https://www.wikiart.org/en/joachim-patinir/charon

periência do mundo, em oposição à faculdade simbólica predominante na arte da Idade Média. A narrativa proposta por Clark (1961) nos mostra razões internas à própria linguagem da paisagem na arte, que propiciaram tal transformação em direção ao registro naturalista do mundo, em meio à arte do gótico tardio, culminando em paisagens com rios em profundidade a perder de vista como as de Joachim Patinir, outro dito "inventor" das paisagens modernas. Na imagem acima, nota-se, pela desproporção entre a figura no barco e o espaço, que a perspectiva científica não exercia grande influência na prática deste pintor.

Em relação ao surgimento da paisagem na arte, Clark afirma que por meio dela a concepção de Natureza se revela em diferentes ciclos e atitudes do ser humano diante do 
mundo em que se insere. $\mathrm{O}$ ciclo correspondente à Antiguidade clássica se voltava mais aos valores humanos; já o ciclo posterior, a partir da Idade Média, buscava criar uma maior harmonia do humano com a Natureza. Ainda assim, segundo o autor, pinturas da paisagemnatureza no mundo grego, eram capazes de reproduzir a expressão da luminosidade sobre o fenômeno natural, mas ela se configurava mais como cenário do que como referência à experiência do natural.

"O pintor helenístico, com a sua visão penetrante dirigida para o mundo visível, desenvolveu uma escola de pintura de paisagem; mas até onde podemos julgar, pelos poucos fragmentos que chegaram até nós, a sua habilidade para registrar efeitos de luz era usada principalmente com fins decorativos. Apenas a série de Odisseu, no Vaticano, sugere que a paisagem se tinha tornado um meio de expressão poética, e até nesse caso os elementos de paisagem são simples cenários, como o é a paisagem na própria Odisseia."(1961, p.19)

Entretanto, Clark nos fala de um "estilo impressionista" da pintura de paisagem grega, em que as sensações ilusionistas da luz eram atingidas com grande êxito, e que ainda sobreviveu após o declínio do estilo clássico, adentrando a Idade Média, em que prevalecia uma representação simbólica dos elementos naturais.

"No precioso documento da junção de dois mundos, a Genesis de Viena, executada em Antioquia cerca do ano 560, o artista conhecido como o Ilusionista deu-nos impressões realistas da atmosfera, da totalidade da paisagem, mesmo quando as figuras eram formalizadas segundo aquilo a que chamamos a maneira bizantina. (1961, pp. 19-20)

Clark aponta que, para entendermos o início da pintura de paisagem, devemos compreender que o ciclo da paisagem simbólica, em que a representação da natureza não 
corresponde à sua aparência real, que se deu na Idade Média, se explica pela mentalidade e pela filosofia cristã medieval. Tal ponto de vista corresponde à mentalidade monástica, para a qual o prazer das sensações deveria ser evitado. $O$ temor à Natureza para o leigo medieval e para o trabalhador rural era de outra natureza: a floresta e o mar eram vistos como hostis e aterradores e o campo era associado ao trabalho duro e à exploração agrícola.

Haveria na mentalidade medieval a faculdade de simbolizar: "[...] este poder de substituir imediatamente uma ideia por um objeto e um objeto por uma ideia[...]"que tornava aceitáveis representações da natureza que para nós parecem inaceitáveis e incompreensíveis."Quanto menos uma obra nos interessa como imitação, mais nos agrada como padrão, e uma arte de símbolos sempre desenvolve uma linguagem de decoração.” (1961, p. 21)

A arte simbólica da paisagem seria então, para Clark, de caráter decorativo: a abstração formal dos elementos naturais era realizada com uma beleza específica do ato de simbolizar. A expressão do divino na forma dos elementos naturais individualizados, como folhas, ramos e gavinhas decorando capitéis, teriam sido o primeiro alvo de interesse da mimese na baixa Idade Média, cerca do século XIII. A ideia de conjuntos simbólicos desses elementos naturais é que teria sido a etapa seguinte, em direção à pintura de paisagem. Os jardins, redescobertos no século XII, correspondiam a “[...] uma parte do ressurgimento geral da faculdade de imaginação. A grande multiplicidade de sensações, considerada tão perigosa por Santo Anselmo, torna-se agora aceite pela Igreja como uma antevisão do Paraíso." (1961, p.22) Sobre essa concepção positiva do natural, obras de grande expressão como a Divina Comédia, põem a presença de uma nova abertura às sensações e à beleza da natureza, na qual o Criador se manifesta, apontando já para a paisagem no sentido idílico:

"Dante inicia sua viagem (é o único fato que é geralmente lembrado) num bosque escuro; aproxima-se do fim quando o bosque é menos denso e vê para alem de um 
Abaixo [imagens 9 e 10], Ambrogio Lorenzetti, Detalhes da Alegoria do Bom ou Mau Governo. c.1338. Afrescos, Palazzo Pubblico, Siena.

Fonte:https://athena-xxi.blogspot.com/2018/10/

ambrogio-lorenzetti-alegoria-e-os.html regato uma senhora cantando e apanhando flores que orlam a vereda por onde segue" (1961, p.23)

As primeiras pinturas da paisagem simbólica indicadas por Clark são afrescos de Lorenzetti e Simone Martini, na tradição da pintura de Siena do início do século XIV. A tradição florentina de Giotto, mais atenta à figura humana e aos gestos, não apresentava representações realistas da paisagem-natureza. Clark considera que as primeiras paisagens no sentido moderno são as da Alegoria do Bom ou Mau Governo de Lorenzetti. Mas trata-se de paisagens do mundo urbano, e seu caráter simbólico é questionável, como nos afirma o autor: "São tão realistas que dificilmente as podemos incluir na paisagem simbólica e mantêm-se únicas durante quase um século." (1961, p.24-25) De fato, os afrescos evidenciam uma tal desenvoltura no emprego realista de meios pictóricos e no registro factual e topográfico da paisagem e da cidade, que nos levam a pensar sobre o quanto dos recursos visuais do Renascimento florentino já estavam desenvolvidos na baixa Idade Média.

À mesma época, temos na figura de Petrarca o grande precursor do conceito da
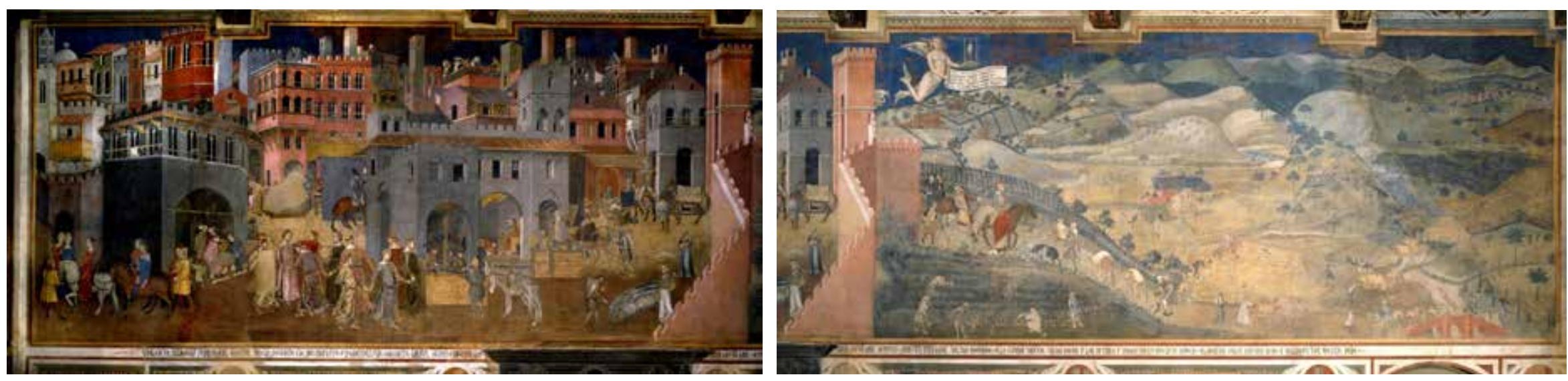
17. Cf. BESSE, Jean-Marc. Ver a Terra - Seis ensaios sobre a paisagem e a geografia - São Paulo : Perspectiva, 2014. pp. 1- 15 paisagem moderna ${ }^{17}$. $\mathrm{O}$ poeta não nutria terror pela natureza e, muito pelo contrário, estudava as características das flores como um homem moderno. O episódio de sua subida à montanha para ver o panorama do alto é, no entanto, exemplar da relação ainda medieval que tinha com a natureza, uma vez que, segundo relata, abriu as Confissões de Santo Agostinho e leu a passagem em que o monge critica os homens que "[...] admiram a altura das montanhas, a força das ondas do mar, a força das correntes dos rios, a vastidão do oceano e o movimento das estrelas, mas não pensam neles próprios”. A conclusão de Petrarca é a de que pela vista da paisagem, ele pode voltar a si mesmo, a admirar a beleza maior, que é a da alma. Há em Petrarca um misto de espírito moderno e medieval, monástico, que exprime muito do que é o início da pintura de paisagem moderna. Como lemos em Clark:

"Nada pode dar uma ideia mais clara do estado de espírito que produzia a pintura de paisagem nos fins da Idade Média. A natureza no seu conjunto ainda é perturbante, vasta e atemorizante; e as vastidões abrem ao espírito muitos pensamentos perigosos. Mas, neste campo selvagem, o homem pode criar um jardim fechado." (1961, p.26)

A expressão deste novo sentimento das paisagens, segundo o autor, tem seu primeiro exemplo nos afrescos que decoram a Tour de La Garde-Robe no Palácio dos Papas em Avignon. Datadas de 1343, estão associadas à tradição de tapeçarias francesas. Seriam “[...] os primeiros exemplos completos da paisagem de símbolos. Mostram pessoas a pescar num lago de jardim, a caçar com falcão e com furão, gozando despreocupadamente a vida ao ar livre. (id. p.27) Há nestas paisagens das tapeçarias de Avignon a ideia de uma natureza toda bordada, em que cada centímetro da composição nos mostra padrões de folhas e ramos de grande beleza compositiva. É uma interpretação formalista e, no entanto, realisticamente poética da natureza.

No Norte da Europa, o ceticismo não permitiu que este tipo de paisagens-jardins 


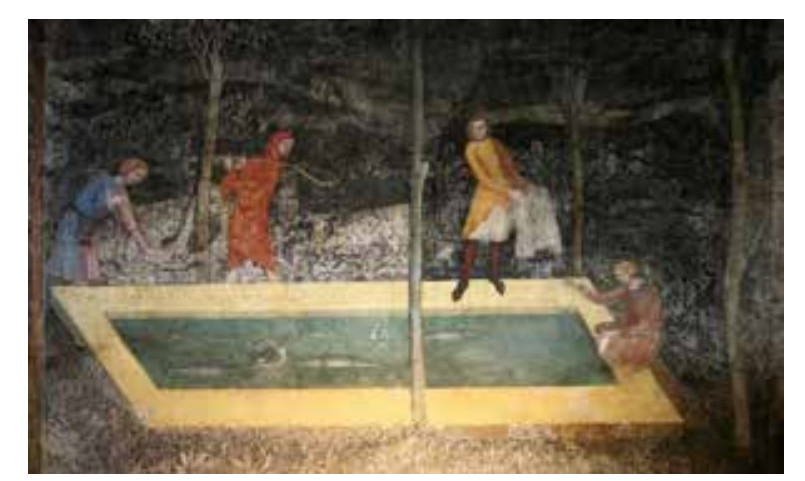

Acima [imagem 11], Autor Desconhecido, Tour de La Garde-Robe. 1343. Afresco. Palácio dos Papas, Avignon.

Fonte: http://www.boarstooth.net/mens-gowns/ se desenvolvessem na pintura, pois "[...]tornava insustentável esta visão de felicidade[...] ; apenas reapareceram cerca de cem anos mais tarde na forma grotesca e terrível de Hyeronimus Bosch, que utilizou o estilo neogótico como a melhor forma de exprimir o seu desgosto pela condição humana.” (1961, p.29) O autor indica aí, portanto, uma das razões pelas quais a paisagem dos pintores do Norte teria se desenvolvido de modo tão diverso em relação à pintura do renascimento italiano: a influência da paisagem gótica não se efetivou, dando vazão a um outro registro do olhar, que viria a ser o das "paisagens de fantasia" maneiristas e o da "paisagem dos fatos", pautada em uma relação descritiva, topográfica, tipicamente burguesa com o território.

$\mathrm{Na}$ França, as primeiras expedições paisagísticas em que era praticado o registro de observação do natural, teriam sido ocasionadas por hábitos esportivos como a caça. Como nos informa Clark:

"Os afrescos de Avignon representam caça, pesca e caça com falcão; e as primeiras pinturas relacionadas inteiramente com a observação natural aparecem em manuscritos sobre esportes." (1961, p. 31)

Como a caça era a principal ocupação da aristocracia nas cortes da França e de Borgonha, no que toca ao espaço externo e extra-muros, é evidente que há uma relação fundamental entre ela e a pintura de paisagens, na medida em que a paisagem campestre e os bosques eram cenário para o tema da caça, sendo ele uma demanda específica de um mecenato aristocrata. Entre os exemplos deste gênero estão as iluminuras do calendário do manuscrito Trés Riches Heures, executadas pelos irmãos Limbourg. Esta pintura de paisagem aristocrática, que, segundo Clark, já tinha muito pouco do simbolismo medieval, se expandiu rapidamente para a Itália em nomes como Gentile da Fabriano e Pisanello e Paolo Ucello. As cenas agradáveis de divertimentos em meio à natureza se tornaram o 

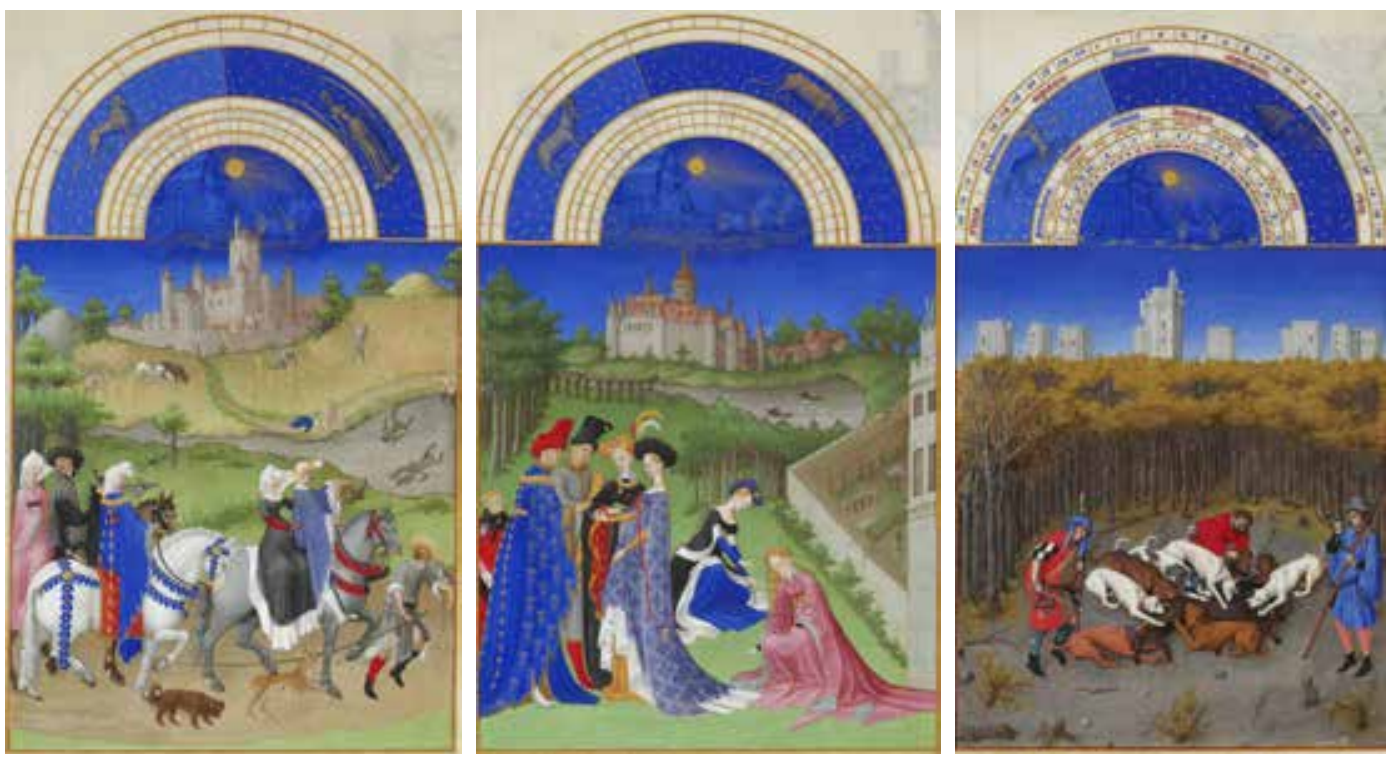

tema favorito da decoração profana no século XV.

Sobre o declínio da paisagem dos símbolos, Clark nos afirma que o procedimento de se "reunir preciosos fragmentos de natureza num conjunto decorativo" não mais satisfazia o gosto pelas paisagens, o que se devia a uma nova ideia de espaço e a uma nova concepção de luz.

"Na paisagem dos símbolos o elemento de unidade era a superfície plana da

Ao lado [imagens 12, 13 e 14], Irmãos Limbourg, Les Trés Riches Heures du Duc de Berry, avril, août et décembre, .c.1415. Iluminuras sobre papel velino Fonte:https://commons.wikimedia.org/wiki/ File:Les_Tr\%C3\%A8s_Riches_Heures_du_duc de_Berry_avril.jpg parede, painel ou tapeçaria. Isto não é uma forma infantil ou irracional de registrar experiências visuais, pois o nosso olhar não se fixa num único ponto, mas move-se, e nós movemo-nos e perante ele passa uma procissão de objetos. Mas cerca do ano de 1420, uma mudança na ação da mentalidade humana, exigindo um novo sentido de unidade, fechou o espaço. Dando grande amplitude ao sentido do termo, podemos chamar científica a esta nova maneira de encarar o mundo, pois implica um sentido de relação e comparação, assim como de medida, sentidos esses em que se baseia a ciên- 
cia. Mas antecipa-se em quase duzentos anos ao verdadeiro surto da ciência, e encontramo-la na obra de artistas que não parecem ter-se preocupado com as matemáticas da perspectiva, em FraAngelico e nos iluministas do Norte. E então está combinado com um outro meio unificador, a luz."(1961, p. 34)

O sentido unificador de luz, que não mais agrupa os pormenores da paisagem sob o critério decorativo, de que fala Clark, se pronunciaria em algumas obras de Gentile da Fabriano e em Fra Angelico. Mas a luz só se tornou o motivo principal da paisagem nas pinturas dos Limbourg e nas obras dos irmãos Van Eyck, cujo exemplo inaugural da paisagem moderna seria a Adoração do Cordeiro. Clark ainda considera esta pintura como um "ponto máximo da paisagem de símbolos", pois ainda se pode ver nela a representação de flores e folhas com uma entidade individual de sentido gótico na descrição de um jardim paradisíaco. Por outro lado, como nos diz Clark:

"Mas o jardim florido não é fechado pelas árvores nem mesmo por uma orla de rosas. Como em qualquer paisagem de Claude Monet, o nosso olhar flutua sobre os relvados floridos até uma distancia de luz dourada. Acabamos de fugir da Idade Média. Entramos num novo mundo da percepção que éo assunto do próximo capítulo." (1961, p.35)

Portanto, Clark já nos antecipa que a "paisagem dos fatos", da qual trata em seu livro um capítulo posterior ao da "paisagem dos símbolos", se caracteriza pela atitude perceptiva em relação à paisagem. Seria um olhar proto-científico aquele que guiou a arte para as paisagens dos fatos e para as topografias da pintura flamenga, e a luz como elemento unificador exercerá o papel de mediador desta nova forma de ver a paisagem no Renascimento.

Em relação ao nosso questionamento sobre o papel do rio como forma simbólica que dá sentido às paisagens modernas, talvez Clark não tenha fornecido a resposta mais direta. Mas, certamente, o outro caminho por ele fornecido, o de que a razão da transfor- 
Abaixo [imagem 15], Jan Van Eyck, Adoração do Cordeiro de Deus (Retábulo de Ghent). c.14301432. Museu de Belas-Artes, Ghent.

Fonte:http://dominusiesus2012.blogspot. com/2013/11/adoracao-ao-cordeiro-quadro-dejan-van.html mação se deu em função de uma imersão no mundo da percepção, protagonizada pela luz, nos indica uma saída universalizante: o olhar pictórico dirigido à paisagem, à medida em que se enamora dos efeitos da luz, encontra na expansão da visão em direção aos horizontes uma razão de ser, e anseia pelo contato direto com a natureza, aspirando à distância.

Em meio a essa dinâmica, o rio, que é irmão da luz celeste, guia o olho em direção ao horizonte, estabelecendo uma ponte entre o próximo e o longínquo, ao longo da qual a luz, numa dança com as sombras, pode incidir com leveza sobre todas as coisas. A narratividade exercida pelo rio é cativa da narratividade da luz, e assim nossa história da paisagem pode prosseguir.

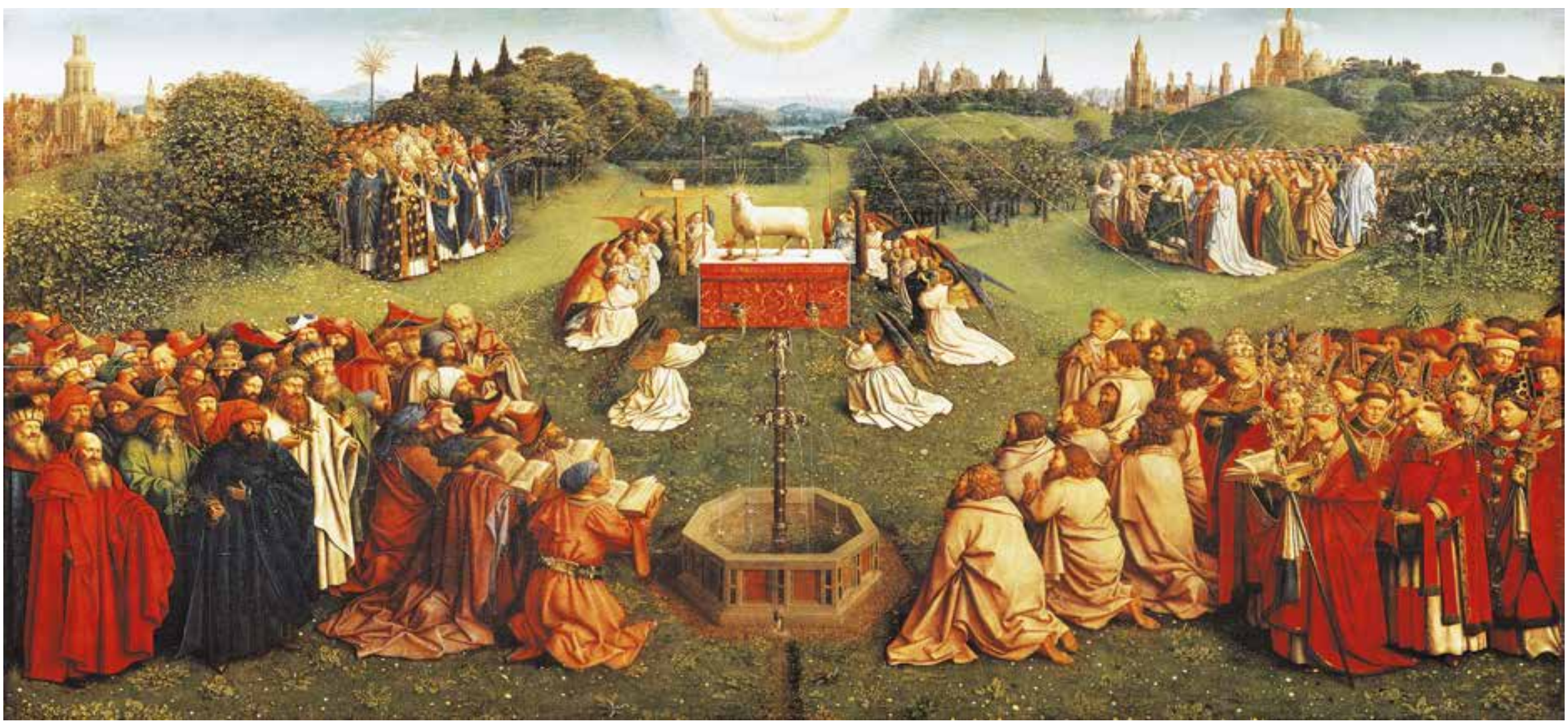





\section{CAPíTULO 2}




\section{2.}

\section{Diante da margem do rio - a horizontalidade}

Nas cidades, para além de sua dimensão simbólica e metafórica, compreende-se o rio como configurador de uma experiência de ampliação de horizontes, constituindo uma sintaxe visual singular na espacialidade urbana. Ver o mundo junto aos grandes rios urbanos proporciona, na maioria dos casos, a percepção de um esvaziamento, de uma ausência de projeto, destinação e apropriação do espaço da cidade. Os “não-lugares” à margem dos rios urbanos definem-se, quando muito, pela própria contingência de serem espaços em que o tecido urbano é necessariamente interrompido por uma linha. O sentido desta linha, que secciona a cidade, nos aponta para uma percepção de horizontalidade, pois à margem do rio a massa construída é menos densa, e já não bloqueia tanto a possibilidade de se olhar à distância, e de se ver a um só tempo uma grande dimensão espacial da cidade.

Se uma das principais referências imagéticas da cidade como paisagem costuma ser a vista a "voo de pássaro", do topo dos arranha-céus ou de fotografias aéreas, nos interessa, contudo, ver a cidade como paisagem ao nível do solo, rasteira. O rio caminha junto às estruturas e fundações da cidade, aflorando do subterrâneo e escondendo-se novamente. A cosmicidade da paisagem fluvial se reafirma por trazer à luz o que está na base, ao mesmo tempo em que amplia o céu, pelo seu reflexo na água, em um sentido de universalidade.

Como mediador entre espaços marginais, o rio é símbolo e fato de uma divisão, de uma duplicidade. Suas margens são, assim, locais propícios à reflexão, nelas elevada a uma segunda potência. $\mathrm{O}$ intrínseco paralelismo das margens ocasiona um espelhamento fundamental, anterior ao espetáculo da reflexão da luz na água, uma vez que aquele que vê a margem oposta, que é a alteridade de seu ponto de vista, vê o outro lado com distanciamento contemplativo.

Num exercício de descrição, poderíamos ensaiar uma "fenomenologia" do evento de olhar a cidade à margem do rio, e, para tanto, o estilo de pensamento de Merleau- 
1. Cf. MERLEAU-PONTY, M. Fenomenologia da Percepção. São Paulo : WMF Martins Fontes, 2011
Ponty ${ }^{1}$ nos dá insumos para poder refletir sobre a experiência perceptiva. Para um corpo que se desloca ortogonalmente à linha do rio, o rio é obstáculo, e na falta de meios para transpor tal obstáculo, resta ao corpo interromper o caminhar e prosseguir somente pelo movimento dos olhos. O olho então procura, perscruta, e se aprofunda na margem oposta em busca da extensão e dos horizontes. Da tentativa inconclusa de possuir pelos olhos a outra margem, resulta também um retorno a si. Novamente, a imagem da travessia à outra margem do rio alude à reflexividade da contemplação paisagística. Nela, a alma sai de si e emerge novamente em um novo corpo, e em um novo mundo.

À margem do rio se configuram, assim, situações de tomada de distância, convocando o olhar a deslocar-se e mover-se onde os pés não alcançam. O olho realiza a travessia, e caminha paralelamente ao corpo, alinhando perfis do mundo que vê, em direção aos horizontes do movimento ocular. A divisão colocada pelo rio ocasiona que só possamos perceber o espaço da margem oposta em termos, de certa forma, abstratos, pois o que se mostra a nós aparece em função de um outro modo da profundidade, um modo de espacializar as coisas que é alheio ao movimento das pernas e à percepção espacial mais imediata.

A profundidade parece reduzida, não temos mais intimidade com as dimensões que separam os perfis das coisas vistas na outra margem. A "planificação" da paisagem mostra uma de suas características fundamentais: o artifício de "trazer para mais perto" diferentes partes do mundo simultaneamente. $\mathrm{O}$ olho percebe a paisagem à medida em que rearranja e reconstrói relações de profundidade entre as diferentes porções de mundo que se apresentam. Os planos e perfis do mundo visto como paisagem se embaralham, se ocultam e se desvelam parcialmente, em uma dinâmica de reconfiguração da extensão do espaço. É condição para observar a paisagem a constatação da relação entre o próximo e o distante. A percepção útil e motora do espaço recua, para que avance, operando em um modo de construção, relações entre diversas partes de espaço, vistas sobre um fundo des- 
2. Nesse aspecto específico, é necessário apontar a distinção entre o horizonte do "senso comum" do qual falamos, daquele que o filósofo nomeou de "estrutura objeto-horizonte", que seria equivalente à sua concepção perceptual de "perspectiva", desdobrada de uma estrutura elementar da percepção, a relação "figura-fundo": " Na visão, [...] apoio meu olhar em um fragmento da paisagem, ele se anima e se desdobra, os outros objetos recuam para a margem e adormecem, mas não deixam de estar ali. Ora, com eles, tenho à minha disposição os seus horizontes, nos quais está implicado, visto em visão marginal, o objeto que fixo atualmente. Portanto, o horizonte é aquilo que assegura a identidade do objeto no decorrer da exploração, é o correlativo da potência próxima que meu olhar conserva sobre os objetos que acaba de percorrer e que já tem sobre os novos detalhes que vai descobrir."( 2011, pp.104105)

Na página seguinte [imagem 16], Ponte Cidade Universitária (córrego Pirajuçara), 2013. Água forte e água tinta s/ papel de algodão. 8 × 30,5 cm conhecido, um horizonte que não vemos².

É importante notar que esse fenômeno varia com a tomada de posição diante da paisagem. Quanto mais próximos ao solo estamos, mais os perfis de paisagem vistos avançam em nossa direção. Quanto mais subimos em direção ao céu, mais eles se distanciam entre si e recuam para longe. Uma visão "a voo de pássaro" parece nos aproximar do horizonte, e quanto mais nos apossamos da profundidade e extensão do espaço, mais o horizonte se torna visível. Quanto mais próximos do chão estamos, mais o horizonte recua, se perde de vista. Torna-se imaginário, intangível, e é substituído por uma infinita sobreposição de horizontes, em que não mais podemos ver a extensão e a distância claramente; é preciso que o olho seja incisivo e perscrute a massa de planos e perfis que se amontoa diante dele, para que perceba e intua a espacialidade que há entre eles.

Como configuração formal básica, vemos nas paisagens da margem do rio Pinheiros uma composição de faixas horizontais, os perfis topográficos da cidade construída em torno do rio. Nas imagens das margens do rio Pinheiros, a profundidade do espaço se contrai, e torna-se quase planificada. É então na luminosidade, na tonalidade e na textura gráfica que cada plano constrói visualmente uma espacialidade. Linhas de força mais ou menos inclinadas definem sentidos de movimento e direcionamento do olhar, em contraste com a presença mais discreta de elementos verticais, que, dispostos mais ou menos regularmente, balizam o ritmo do movimento visual das faixas horizontais.

Trata-se de uma estrutura visual relativamente simples, e ela é presente na maior parte da série de vistas do rio. A percepção de horizontalidade nas vistas, o caráter panorâmico que se associa tradicionalmente à ideia de paisagem, se reafirma com uma contundência quase exagerada. A horizontalidade dinâmica da paisagem torna-se quase o seu motivo principal, e a série poderia ser, sob os termos de uma "abstração formal", como um estudo sobre composições com faixas horizontais. Há uma tentativa de testar até que 


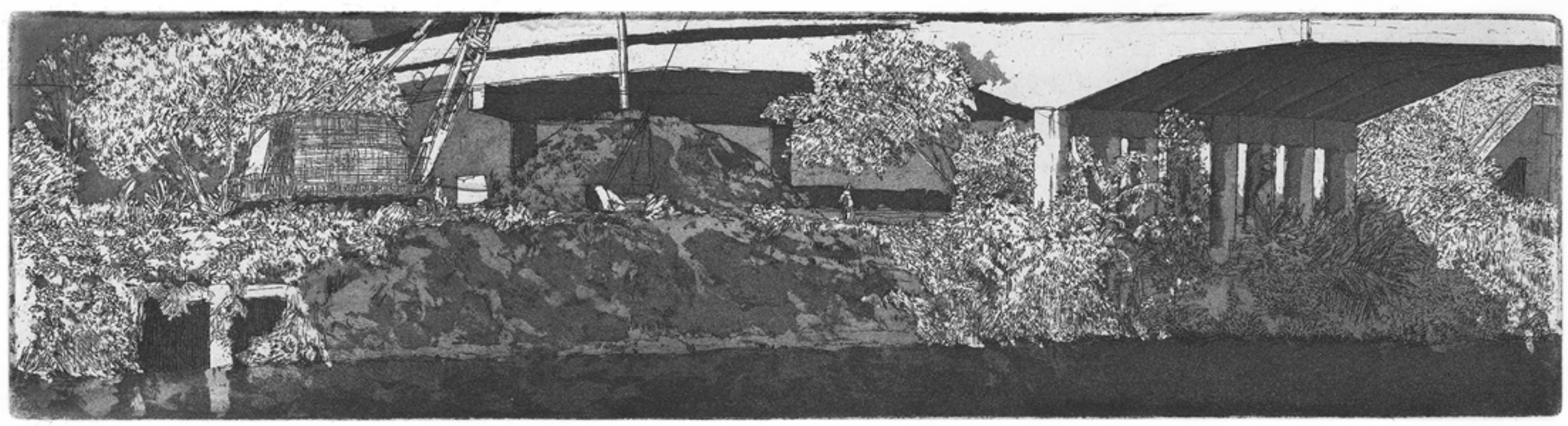


3. A esse respeito, Merleau-Ponty observou o quão abstrata é a noção de um campo visual, e que ela se aplica mais à óptica e à geometria aplicada à oftalmologia do que de fato à percepção. Esse "campo visual" não apresenta contornos ou limite definido em relação a uma zona "negra” "ou “cinza"correspondente à ausência de visão. Se a percepção do olho correspondesse ao mecanismo da retina, "Deveríamos portanto perceber um segmento do mundo contornado por limites precisos, envolvido por uma zona negra, preenchido sem lacunas por qualidades, apoiado em relações de grandeza determinadas como as que existem na retina. Ora, a experiência não oferece nada de semelhante e nós nunca compreenderemos, a partir do mundo, o que é um campo visual. Se é possível desenhar um Perímetro de visão aproximando pouco a pouco os estímulos laterais do centro, os resultados da mensuração variam de um momento ao outro e nunca se chega a determinar um momento em que um estímulo inicialmente visto deixa de sê-lo. Não é fácil descrever a região que rodeia o campo visual, mas é certo que ela não é nem negra nem cinza. Há ali uma visão indeterminada, uma visão de não sei o quê, e, se passamos ao limite, aquilo que está atrás de nós não deixa de ter presença visual." (2011, pp. 26-27)

Na página seguinte [imagem 17], Ponte Eusébio Matoso, 2014. Água forte e água tinta s/ papel de algodão. $11 \times 30 \mathrm{~cm}$. ponto resiste essa percepção de horizontalidade da paisagem, de tencionar os limites desta convenção visual. É difícil dizer até que ponto ela é só cultural, pois poderia de algum modo estar amparada na fisiologia da percepção visual do ser humano: uma vez que o

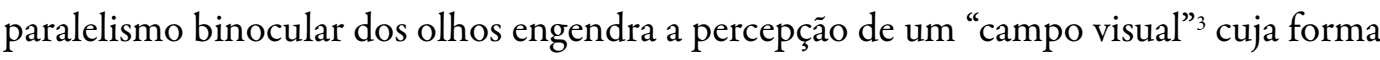
mais comum de representação remete à de uma elipse horizontalmente disposta.

Mas é de fato a margem do rio, alinhada à planaridade da água, com sua forma rigidamente construída, regular e retilínea, que nos coloca tal percepção de horizontalidade. Como escapar a ela? E por que subvertê-la ou tentar negar que ela existe? Certamente ela não é a única, e sabemos ser possível pensar a paisagem de modo vertical. Mas ainda assim ela persiste, e predomina. Talvez enfrentá-la como tal, debruçar-se sobre ela seja um caminho, e não necessariamente o mais interessante ou mais rico. Impõe-se que a poesia de tal horizontalidade seja justamente a constatação de que ela não é monótona, de que linhas e faixas do mundo se movimentam sutilmente numa dança lenta de inclinações, arcos e perpendicularidades que se interpõem entre elas.

\section{O céu como luminosidade}

A imagem que segue é quase estritamente frontal, e as faixas horizontais levemente inclinadas à esquerda sugerem alguma perspectiva nessa direção. Entretanto, a perspectiva mais marcada é aquela da ponte sob a qual o espectador se situa, que quebra violentamente a horizontalidade. A obscuridade central sob a ponte contrasta com uma luz ofuscante, que incide lateralmente, da esquerda para a direita, criando duas linhas de força paralelas em diagonal, que sutilmente banha as árvores à direita da ponte, ao passo que invade a estrutura de sustentação à esquerda.

O céu, de um cinza mediano, se entrevê timidamente por detrás das árvores, que 


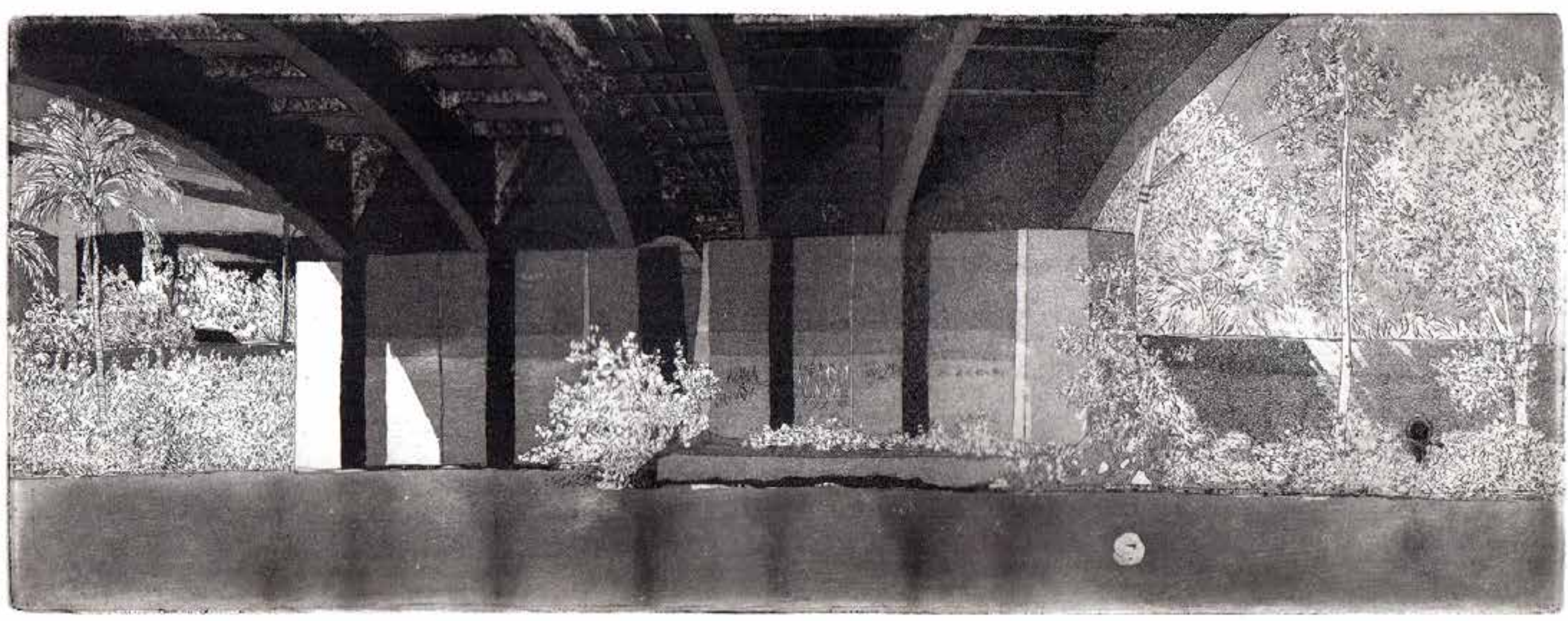


estão iluminadas, brilhando sob um sol escaldante. A singularidade da luz nessa paisagem se deve ao fato de ela ser retratada de um ponto de vista sombreado, ao contrário das outras gravuras da série, e isso exagera o contraste por uma inversão perceptiva da luz,em que tudo o que está fora da área central sombreada é de uma luminosidade ofuscante, ainda que o céu se mostre um tanto escuro.

Parece haver nessa horizontalidade obsessiva das margens do rio uma inconsistência, a princípio: ela só é possível por não trazer a imensidão vertical do céu. As imagens omitem a percepção inalienável do céu na paisagem, ou, quando muito, colocam-no como uma faixa que ocupa o plano superior da composição. Essa horizontalidade poderia ser a desculpa de um mau desenhista de céus, que resolve o problema de sua incompetência dando-os como algo pressuposto, algo que à imagem cabe somente sugerir ou aludir, uma parte da paisagem que está à margem da estampa, um dado para a imaginação do observador.

Imaginemos adicionado às imagens um vasto céu: se tornariam estampas de formato quadrado ou "retrato". Feito isso, onde estará a paisagem da margem? Continuará na parte inferior, ou fará parte de um todo maior? Ou se tornará pouco visível na composição, de forma a se dissolver no céu simplesmente?

Por razões práticas do trabalho, como economia de meios, questões compositivas, escolhas técnicas, poderia se explicar o porquê de o céu ser "menos visível” em tais paisagens. No entanto, há nelas a afirmação veemente de uma percepção paisagística em que o céu se "esconde", ou recua em relação ao avanço da superfície da terra. Não se trata só de uma questão de escolha de enquadramento. Há um propósito em representar a paisagem deixando o céu "de lado". A imagem traz uma percepção do céu como algo que está parcialmente aquém da visibilidade, que ilumina o mundo visível de cima a baixo. É uma paisagem em que o céu está implícito, mas participa como elemento semi-oculto. 
Parece uma percepção de paisagem com uma condição parcial, segundo a qual ou se olha o céu, ou se olha a terra. Um esconde o outro; um tão paisagístico quanto o outro. Em resumo, a descida ao nível da margem do rio implica, assim, uma escolha pela vista parcial da paisagem do rio, onde não abarcamos o horizonte, mas entrevemos fragmentos de horizontes entre os perfis que se alinham à nossa frente. Postados ortogonalmente à margem do rio, ortogonalidade que se reafirma na característica retilínea de seu leito canalizado, vemos uma paisagem de horizontalidades paralelas. A verticalidade das coisas parece se dissolver a ponto de o céu quase sumir, mesmo estando plenamente à vista. A sua existência se coloca somente na extremidade mais alta da vista, pois o que define a paisagem da margem é a horizontalidade dos elementos visuais. Seu caráter panorâmico, longilíneo, permite que o céu apareça como linha no topo do contexto visual.

Este modo de ver as paisagens, caracterizado pela representação da horizontalidade, traz consigo o problema da verticalidade dos céus. A importância dada aos céus como parte significativa da "alma" das paisagens é uma constante na história da arte e define-se culturalmente com grande ênfase. Somos apaixonados e dependentes de céus, pois eles nos são negados cotidianamente na vida urbana. A oportunidade de ver céus abertos tira o peso opressor dos edifícios que os escondem. De forma que as paisagens são praticamente indissociáveis da presença dos céus, e ele é um parâmetro da abertura e cosmicidade experimentada nas paisagens. No entanto, o céu não aparece na representação das paisagens somente em sua figuração literal: ele aparece tanto como manifestação particular da própria luminosidade da paisagem, de uma dinâmica de movimento das sombras, suas tonalidades e seus contrastes. Sua identidade figurada é, em muitos casos, complementar à sua existência luminosa, que vemos em cada superfície de cada coisa que habita uma paisagem.

Nos rios temos um caso exemplar, em que o céu e as nuvens são vistos mais pelo 
Na página seguinte [imagem 18], Ponte da Cidade Jardim, 2014. Água forte e água tinta s/ papel de algodão. $11 \times 29 \mathrm{~cm}$. reflexo nas águas do que enquanto eles próprios. O céu aparece mais como luminosidade que vem de cima, do que como elemento de uma composição espacial da paisagem. Nesse sentido, as imagens das margens do rio são expressão de uma paisagem em que o céu participa como luminosidade: a paisagem como "assunto" ou motivo estão no solo, em seu relevo e topografia.

A imagem da página seguinte [imagem 18] expressa bem o que viemos discutindo, e se nela o céu aparece ocupando uma porção maior do que nas gravuras anteriores, o seu valor tonal é mais escuro, como a representar o azul profundo de um dia outonal. A luminosidade desse céu aparece, então, pela incidência na vegetação e nas superfícies iluminadas da ponte. A tonalidade da superfície da água também contribui para emanar a luminosidade e o calor do sol refletido, e em grande medida isso ocorre pelo contraste com a densa sombra da ponte sobre o rio.

Em relação às anteriores, esta imagem sugere uma frontalidade menos pronunciada, e a horizontalidade se faz mais perspectivada: podemos ver a margem do rio se distanciando na extremidade direita, e mais do que qualquer uma das outras imagens, esta paisagem indica o longínquo na porção de mundo distante que vemos por debaixo da ponte. $\mathrm{O}$ olhar enviesado, que busca abarcar a maior extensão possível da ponte na imagem, acaba por uma paisagem com dois pontos de fuga perspectivados, nas extremidades esquerda $\mathrm{e}$ direita. Mas ainda é o sentido do rio o que comanda a sensação de direcionamento, por mais que o arco da ponte se imponha pesadamente, apontando para outra profundidade à esquerda.

A torre de eletricidade se assenta soberana ao lado da ponte, como um ser postado contemplando a vista, e exerce um contrapeso à centralidade da estrutura da ponte. O fato de os elementos verticais serem mais altos do que a extremidade superior da imagem, em que aparecem com suas pontas cortadas, produz certa sensação de tensão e rigidez, que 


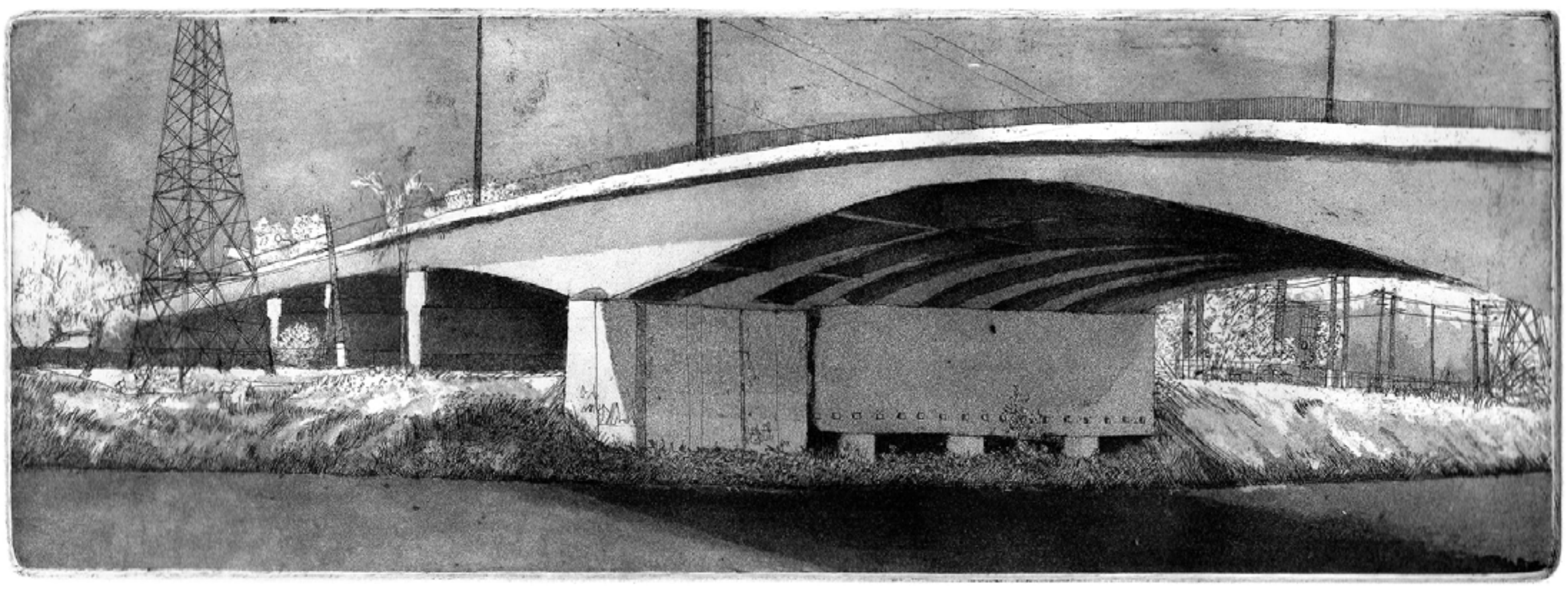


se reflete na horizontalidade arqueada da ponte, como se ela estivesse sustentada por cima, pendurada ou estruturada por cabos chumbados no céu, além ser fundada no solo pelos pilares à margem do rio, ao centro da imagem.

\section{O nó da linha do rio é a ponte}

Em resumo, é significativo que até aqui todas as imagens descrevem a situação paisagística que ocorre junto às pontes que cruzam o rio Pinheiros. As paisagens que se registra são as da passagem, e não do repouso. Há nela sempre uma continuidade de elementos direcionados, sentidos de movimento. Trata-se de cruzamentos, em que instâncias em movimento se confrontam pelo espaço e pelos vetores de força, sempre muito marcados.

As pontes traduzem a soma máxima de forças em movimento, pontuando, sobre uma situação de confronto de duas forças, um terceiro elemento. Uma vez que está em nível elevado em relação ao solo da paisagem, mas ainda próxima dele, nelas se realiza o artifício de ver de cima, sem que se esteja no topo de um edifício. Ocorre nela a tomada de distância e a expressão de uma dominação sobre o fato terreno, mas sem que haja uma separação entre espaço interior e exterior. De cima da ponte, o contato com a paisagem é de outra qualidade; de cima dela não se abstrai a cidade, não se a vê de uma janela, não ocorrendo nela um apartamento do solo urbano. As pontes encarnam a precariedade como espaço urbano, sob a implacável urgência da passagem que dá sentido à sua existência. Pontuam a continuidade da paisagem, e assim se tornam como ligaduras, articulações e nós que estruturam o esqueleto da paisagem das cidades.

Como imagem, símbolo e fato da vida urbana a potência integradora da ponte é tal que Martin Heidegger a toma como exemplo para pensar, em função da linguagem, a 
relação entre o construir e o habitar. Em seu ensaio Construir, Habitar, Pensar, o filósofo nos mostrou como é possível pensar o rio e as suas margens em função da existência da ponte, invertendo a perspectiva que normalmente se tem, da ponte como um objeto que se sobrepõe ao rio; a ponte passa a ser o sujeito de uma relação:

"A ponte pende "com leveza e força" sobre o rio. A ponte não apenas liga margens previamente existentes. É somente na travessia da ponte que as margens surgem como margens. A ponte as deixa repousar de maneira própria uma frente à outra. Pela ponte, um lado se separa do outro. As margens também não se estendem ao longo do rio como traçados indiferentes da terra firme. Com as margens, a ponte traz para o rio as dimensões do terreno retraída em cada margem. A ponte coloca numa vizinhança recíproca a margem e o terreno. A ponte reúne integrando a terra como paisagem em torno do rio." ${ }^{4}$

Retoma-se a questão da travessia, e podemos pensar, como quer Heidegger, que a margem do rio só existe na medida em que se faz atravessar, e uma margem só existe em função da outra e de sua transposição: no nosso caso, a ponte se dá no próprio olhar, e é sintomático que a série sobre a paisagem do rio Pinheiros, no início, confunda-se com uma série de gravuras sobre pontes.

Georg Simmels, por sua vez, nos mostra como a ponte, em sua função prática de

4. HeIDEgGeR, M. Construir, Habitar, Pensar [ Bauen, Wohnen, Denken] (1951) conferência pronunciada por ocasião da "Segunda Reunião de Darmastad”, publicada em Vortäge und Aufsätze, G. Neske, Pfullingen, 1954.Trad. Marcia Sá Cavalcante Schuback

5. SIMMEL,G.-A ponte e a Porta [Pont et Porte] , in Tragédie de la Culture et autres essays, Paris, Rivages, 1988. Trad. Simone Carneiro Maldonado (DCS-UFPb).
“[...] ela se integra, com toda a sua faculdade de síntese que ultrapassa a natureza, à imagem da própria natureza. Para o olhar, a ponte se encontra numa relação bem mais estreita e bem menos fortuita com as margens por ela ligadas, do que, por exemplo, uma casa com o terreno que a comporta e desaparece debaixo dela, ao olhar." (SIMMEL, 1988. p.11) 
As pontes, portanto, não são somente fatos da paisagem do rio Pinheiros, mas constituem parte de sua essência, integradas à natureza do território que se configura junto ao rio. Se as pontes, em conjunto, estruturam a paisagem do rio, não é fortuita a escolha delas como pontos de vista que descrevem um todo maior, que queremos chamar de paisagem. Mas será possível que, por meio de vistas de pontos discretos, particulares, possamos apreender uma característica que é do todo, que unifica e dá sentido ao conjunto, mas que previamente não sabemos qual é?

Nossa pesquisa visual pressupõe uma continuidade linear, e nossa hipótese é a de que pelo deslocamento em linha, junto à margem do rio, possamos recolher impressões e percepções de modo que, nesse processo, elas nos informem conteúdos que não são da ordem do conceito, que não se exprimem, a princípio, por palavras e imagens líricas. Ao fim desse processo (que talvez nunca chegue) poderemos olhar para todo o conjunto de vistas, estabelecer relações sintáticas, semânticas, simbólicas, nexos de toda ordem entre elas. Mas não necessariamente teremos encontrado, definido e dado um nome a esta qualidade que nos põe diante da quase-presença desta paisagem de modo que possamos atestar: é ela. É um risco a se considerar. Faz sentido, então, procurá-la?

\section{A paisagem do rio como linha}

A última gravura desta série inaugura um olhar diferente do das anteriores e isso se deve a um série de razões. Em primeiro lugar, trata-se da primeira gravura em que não se vê uma ponte, e o protagonismo da imagem se divide entre um amontoado de construções em primeiro, segundo e terceiro plano. Em segundo lugar, é a primeira imagem em que temos a cidade verticalizada ao fundo, e isso se deve ao fato de que ela é a primeira em que a margem Leste do rio é retratada, em oposição, às anteriores. Em terceiro lugar, ela é a

Na página seguinte [imagem 19], Estação Vila Olimpia (Córregos Uberaba/Traição). 2016, água forte, água tinta e brunidor s/ papel de algodão. 11 x $30 \mathrm{~cm}$. 


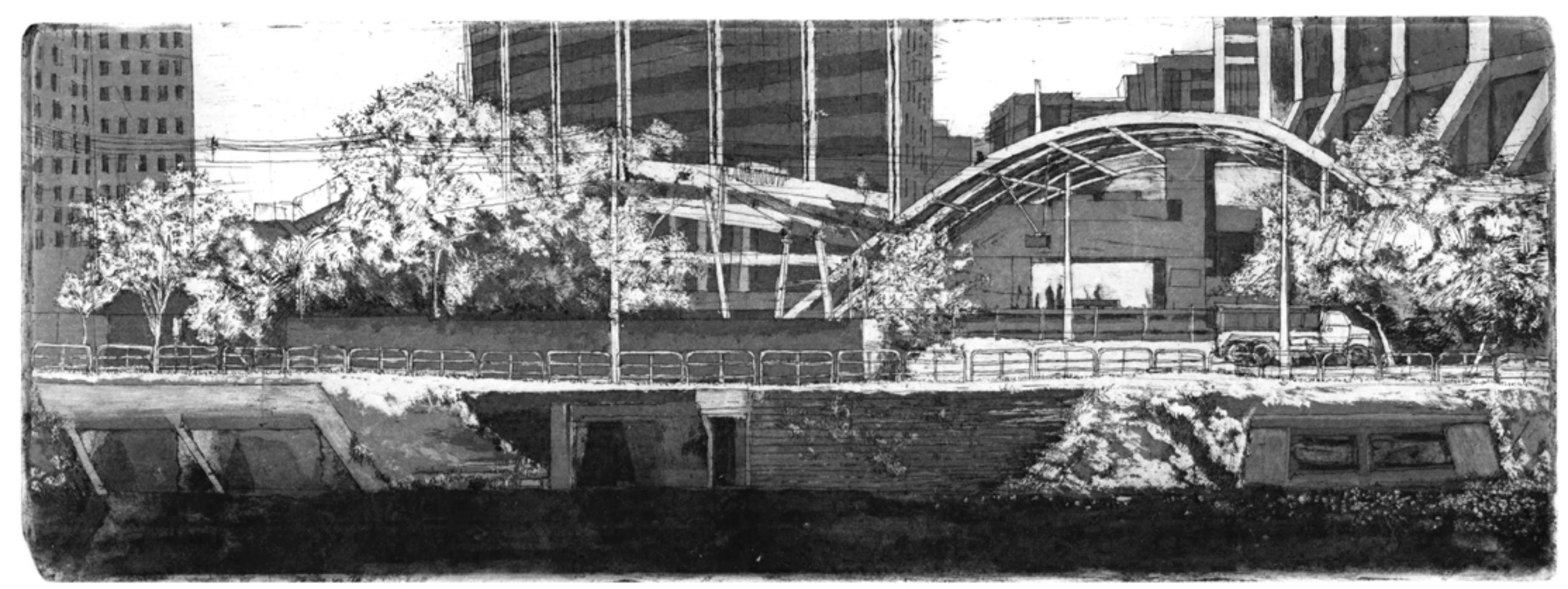


primeira em que a horizontalidade da margem é total, sem qualquer inclinação perspectivada, implicando em uma absoluta frontalidade.

Trata-se de uma paisagem um tanto caótica, em que uma profusão de informações competem pelo olho em um arranjo desarmônico. Por mais que haja uma ordenação, por exemplo no paralelismo equidistante entre os três edifícios ao fundo e as três bocas de córrego em primeiro plano, e que divide a imagem em três massas construídas: à esquerda, ao centro, e à direta, somente o arco da cobertura da estação do trem parece conferir algum foco central à composição, possibilitando ao olhar um breve repouso.

O céu é de uma alvura ofuscante, e a luz difusa sugere o mormaço de um dia nublado. No entanto, a luminosidade da vegetação parece pouco convincente, incongruente com a relativa escuridão dos objetos construídos e dos prédios. $\mathrm{O}$ rio se mostra quase negro, como se a água estivesse tingida e não refletisse o branco acinzentado do céu. Estas características contribuem para que a paisagem expresse uma tensão inexistente nas outras imagens, e a atmosfera rica de cinzas que a gravura em metal propicia é carregada de um peso e de um ardor, que parecem levar ao limite aquilo que na primeira gravura da série se entrevia: a ênfase no exagero nos contrastes de luz e sombra.

Por outro lado, essa tensão violenta expressa, antes de tudo, a aparência da cidade que se constrói à margem oposta do rio. Esta imagem registra a última parada em um percurso em direção ao Sul, e evidencia, pela primeira vez, um processo de transformação radical, que na porção de rio até aqui visitada, mais harmônica, "civilizada" e consolidada, não se via. Não é apenas o fato de que agora olhamos em direção ao centro da cidade o que altera a paisagem, mas a evidência de que, nesse momento do percurso, é esta a face que se mostra mais significativa como expressão da geografia da cidade à margem do rio.

Como já foi dito, esta gravura toca uma característica-chave na percepção que se tem da paisagem do rio e que se articula com o sentido geral de toda a série. Ela se reporta, 
mais do que as anteriores, ao símbolo da linha em sua horizontalidade total. Sua referência direta, na figura da estação de trem, à linha ferroviária que percorre a margem Leste do rio, carrega implícito o fato de que o tratamento paisagístico da margem oposta, vista nas gravuras anteriores, foi feito para ser visto a partir da estação; de certa forma, é a linha do trem que dá sentido à paisagem da margem Leste, Como as pontes, a linha é uma das formas-síntese da razão de ser do rio canalizado, e carrega consigo todas as dimensões de transporte linear em meio aos quais o rio sobrevive: automóveis, trens, bicicletas, escoamento de água e eletricidade. Tudo isso se articula e conflui em sua margem, dando sentido à continuidade de uma linha.

A linha permite a ideia de sequência e intervalo entre interrupções, perturbações da horizontalidade que cadenciam ritmos, conferindo polirritmia ao espaço da paisagem. Ver a linha é dar direção, sentido de extensão. A paisagem pode estar "neutra" se me coloco ortogonalmente à linha; se viro um pouco para um dos lados, já vejo sentidos de movimento, perspectivas.

Ao percorrer as margens do rio, a presença de sua linearidade pode mediar uma leitura contínua e serial da visualidade urbana tal como se dá à percepção ao longo do trajeto. Nesse caso, o rio é o referencial constante para um modo de certa forma "distanciado", marginalizado, de ver a cidade em movimento e de perfil, em "elevação". Todavia, são as variações desse perfil de cidade que acompanha o rio que propiciam, também, visualizar, comparar e elaborar aspectos de uma unidade característica da várzea, de sua geograficidade singular.

Pela continuidade das vistas registradas, a paisagem aparece, então, pela via do desenho, tornando-se linguagem visual, um “vocabulário paisagístico", que exprime sínteses perceptivas de variações de luminosidade, textura, cromatismo, latitude e longitude, figura e fundo, vistas por um corpo que se desloca em uma determinada extensão de espaço. 
6. Cf. MERLEAU-PONTY, M. A linguagem indireta e as vozes do silêncio in: Os Pensadores - Maurice Merleau-Ponty - textos escolhidos : trad. e n. de Marilena de Souza Chauí et al. São Paulo : Abril Cultural, 1980. “ No que se refere à linguagem, se o signo se torna significante por sua relação lateral a outros, o sentido só surge então à intersecção e como que no intervalo das palavras. [...] Se o signo somente quer dizer alguma coisa enquanto se perfile sobre outros signos, seu sentido está todo empenhado na linguagem, a palavra se desenrola sempre sobre fundo de palavra, nada sendo senão um dobra no imenso tecido da fala."(p. 143)
A linearidade é condição para a ideia da "série de vistas": podemos contar pontos discretos que nos dão os ritmos de uma paisagem, mas talvez ela seja estritamente aquilo que se imagina entre eles, o vazio que une os significados que imprimimos numa imagem pontual que, por si só não nos informa o significado geral, que é a paisagem. Como ocorre com os signos na linguagem ${ }^{6}$, que sozinhos não comunicam um sentido, as vistas de uma paisagem só se efetivariam em conjunto. É claro que uma imagem não equivale a um signo, e uma paisagem não equivale a um texto, mas é possível, num exercício de imaginação, conceber a paisagem como o sentido de uma linguagem, da qual nossas representações visuais seriam como vocábulos.

Dessa forma, sugere-se que a paisagem não seja representada pelos pontos em si e isolados, mas sim por uma espacialidade tanto imaginária quanto real, que os envolve, que ocorre entre estes pontos de vista. O que se vê em uma série de vistas não é a própria paisagem: a paisagem é a possibilidade de, segundo elas, idealizar visualmente um todo a que pertençam. 
2.1

\section{O registro geográfico como paisagem}

Ao lago [imagem 20], José Joaquim Freire, Prospecto da entrada da Cachoeira do Ribeirão, a décima do Rio da Madeira.1789. Aquarela e lápis sobre papel $48 \times 24 \mathrm{~cm}$. Museu Bocage, Lisboa

Fonte: .(org.) FERRÃO, C., SOARES, Paulo M.S- Viagem ao Brasil de Alexandre Rodrigues Ferreira - vol. 2 - Petrópolis : Kapa Editorial, 2002. pp. 50-51
As sequências de vistas talvez sejam a principal referência em termos de descrição de paisagens, trazendo intrínseca a noção de deslocamento que se dá entre pontos. Séries de vistas foram comuns ao longo do século XIX, tanto na arte ocidental quanto na oriental. Como exemplos, temos Katsushika Hokusai, que realizou a célebre série de Cem Vistas do Monte Fuji, assim como John Constable, que produziu a série de pinturas de vistas do rio Stour, e já no final do século XX, artistas da Land Art produziram séries de fotografias sobre suas errâncias, como fez Robert Smithson com o rio Passaic.

Evidentemente, a prática também era difundida entre naturalistas com propósito documental de ordem científica, e um dos exemplos mais antigos, e que curiosamente se aproxima muito de nossa produção por suas visadas frontais de margens de rios, é a "Viagem Filosófica" de Alexandre Rodrigues Ferreira, naturalista português do século XVIII, que anteriormente à tradição dos naturalistas alemães que visitaram o Brasil, como Martius e Spix, Rugendas, entre outros, registrou extensas séries de vistas dos rios do Norte brasileiro, como o rio Madeira. $\mathrm{Na}$ imagem abaixo, uma aquarela de José Joaquim Freire, desenhista da equipe de Ferreira:

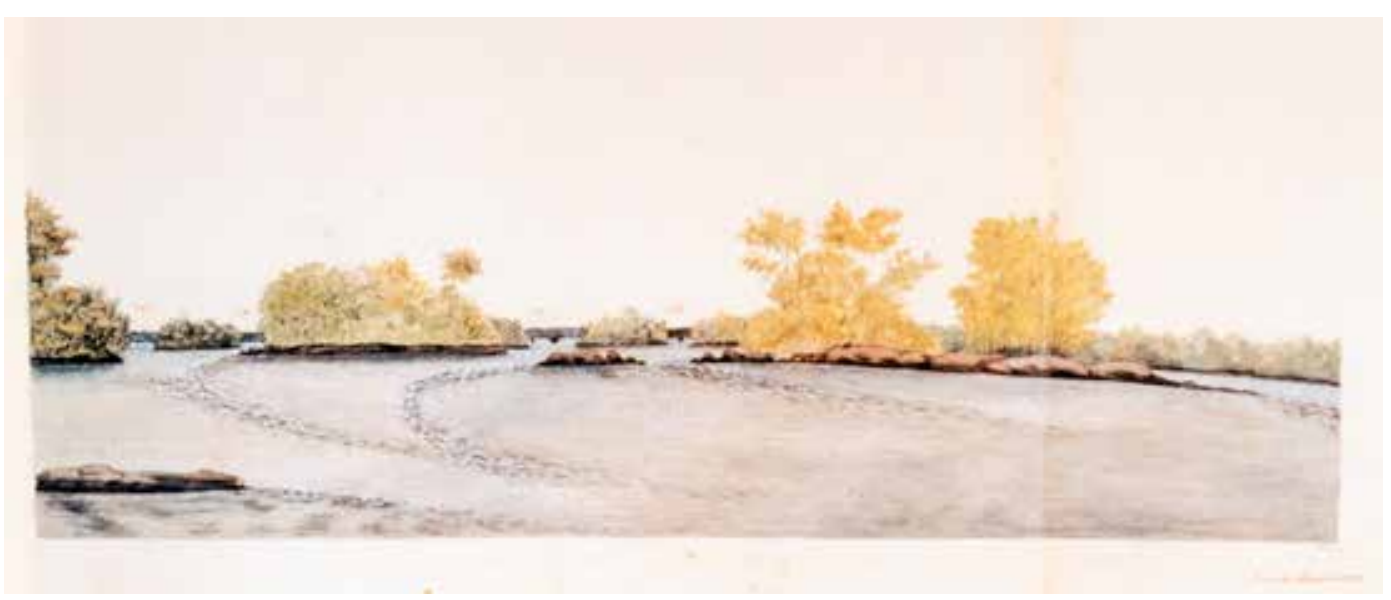


Há um sentido específico da representação colocado pelas imagens de paisagem do rio Pinheiros. Nelas temos, antes de qualquer qualidade poética, a busca da descrição de uma situação específica da cidade, em que se inscrevem pormenores de uma vista que se dá em um local específico, e que reúnem a presença de diversos elementos que configuram aquilo que queremos chamar paisagens do rio Pinheiros.

Portanto, as paisagens que vemos nessas imagens constituem, para além daquilo que se encerra na superfície de cada uma delas, um todo maior que não é imagem, mas a "verdadeira" paisagem do rio Pinheiros, sua existência factual enquanto espaço dado, construído e habitado. À relação entre essas imagens corresponde uma relação formal "sistêmica", quiçá territorial, entre várias vistas de porções de uma extensão de espaço, inabarcável em uma só visada. Esta extensão de espaço, segundo algumas de suas características fundamentais, pode ser compreendida como uma paisagem.

Há nas sucessivas vistas algo que as unifica, e que se nutre tanto daquilo que elas têm de diferente entre si, quanto daquilo em que se parecem. Este "algo" dá sentido às generalizações proferidas em relação às percepções que temos de uma determinada porção do espaço da cidade, que optamos por chamar de paisagem do rio Pinheiros.

$\mathrm{Na}$ medida em que estas imagens, no que se assemelham, coexistem como registros parciais de um determinado local no mundo físico, elas se assemelham também a um tipo de mapeamento, cartografia, ou topografia de uma porção de espaço, no sentido descritivo da geografia. Por mais que não haja um sistema de informação espacializado matematicamente, que possa se aplicar a estas paisagens do rio Pinheiros, existem princípios que norteiam a continuidade entre as porções de espaço descritas nas imagens. Ainda que não seja ela o mote primeiro do trabalho, há que se reconhecer nele uma atitude cartográfica, que remonta à ideia do atlas, na tentativa de abarcar uma porção de mundo pela inscrição de índices de informação sobre tal mundo em um plano de representação. 
A esse intuito cartográfico, que se justifica por uma relação geográfica com o mundo, se sobrepõe a questão da criação propriamente artística ou valor estético das paisagens, o que nos coloca uma das questões que permeiam a história da paisagem na arte: até que ponto o interesse e a subserviência ao dado, ao registro do fato paisagístico, sacrificam a paisagem como expressão artística, relegando-a à utilidade da informação?

Seja uma percepção de luz, uma sensação espacial, ou a textura das folhas de uma formação vegetal, trata-se de algo de singular, que se mostra como dado empírico de uma visão característica do espaço e do mundo, e que, entre infinitas outras coisas, configura aquilo que queremos ver como paisagem. A procura daquilo que é específico ou singular, pelo que é "digno de nota”, e sua posterior inscrição sobre um plano de representação, vem antes de um desejo de síntese visual daquilo que se vê, se sente ou se percebe em determinado local. Há um sentido primário de registro gráfico do mundo que constitui as paisagens, e que o distingue como um tipo específico de imagem. Ele é anterior ao sentido retórico e discursivo das imagens poéticas que se fazem por meio delas.

Há na representação das paisagens um desejo de transcrição da informação de uma visão concreta, factual, que se basta como necessidade mínima à sua criação. Ele antecede a própria expressividade visual de cada imagem de paisagem. É por ocasião desse registro visual e da atividade artística que a expressividade se faz; ela não corresponde a um ideal expressivo previamente definido, ainda que haja intenções do artista.

As paisagens como registro visual de um local parecem ser uma forma de pôr à prova e testar, no mundo visível da representação, o alcance da nossa própria consciência de ver o mundo diante de nós. Pela experiência, construímos mentalmente visões do mundo que somos capazes de resgatar na memória visual, que habitam o imaginário, mas que não vemos propriamente, até que ela se materialize diante de nossos olhos e dos olhos dos outros. Aquilo que se realiza como visão do mundo para nós, nunca será aquilo que outros 
verão em um determinado local; só podemos representá-lo, transcrevê-lo, submetendo nossa visada à mediação de um suporte de linguagem, visual ou não, uma vez que o outro não vê nossa visão, mas vê o mesmo mundo que vemos.

Isso não quer dizer que o mundo visto não seja o mesmo para todos, nem que não seja possível ver exatamente do mesmo ponto de vista que outro já viu. Mas, ainda assim, não podemos atestar aos outros que vimos determinada paisagem, antes que apresentemos a eles algum sinal, que possa ser reconhecido por nós mesmos como correspondente à percepção ou impressão que guardamos de tal lugar. Algum fato, algum dado da experiência que tal lugar proporciona tem de ser transmitido, mesmo que não seja ele a mensagem principal que se quer passar. Este dado ou fato participa em uma estrutura que configura um todo que traz algo da experiência de uma paisagem. Ele, enquanto fato da paisagem, integra sua descrição.

A história das paisagens representadas se confunde, assim, com a história das histórias, dos relatos de viagem, daquilo que se diz de determinada cidade, do registro de uma determinada natureza, enfim, do relato de tudo aquilo que se pode dizer, informar, ou representar da própria experiência histórica do ser humano e de sua relação com o mundo.

\section{A paisagem como expressão da luz}

Uma das mais consagradas leituras históricas da vocação descritiva da paisagem na arte é feita por Clark (1961), sobre um determinado espírito artístico que ele denomina "paisagem dos fatos". À pintura do Norte da Europa dos séculos XIV ao XVII, correspondeu uma característica de ênfase naturalista, fidedigna e até obsessiva com a descrição do mundo em seus pormenores. 
Em relação ao nascimento das paisagens modernas, Kenneth Clark nos introduz à questão da luz como central para a facticidade da paisagem na arte. Para além de um interesse pela aparência naturalista e detalhada do mundo visto, havia um sentido mais profundo de observar as sutilezas e as qualidades particulares da incidência da luz nas coisas vistas, assim como de sua presença atmosférica no ar. Para ele, há uma relação intrínseca entre os pequenos formatos dos primeiros quadros de paisagem flamengos, no século XIV, e a observação direta da incidência da luz na natureza, e ainda a portabilidade dos pequenos painéis de pintura, que possibilitam ao artista trabalhar também fora de seu estúdio.

As pequenas paisagens passam a habitar as iluminuras dos livros, e o autor considera que as precursoras das paisagens modernas teriam sido pintadas por Hubert Van Eyck. A partir das miniaturas e iluminuras, o historiador discute a questão da pequena escala do que chama de "paisagens de percepção", em comparação com a maior escala daquelas executadas em estúdio. O impressionismo teria se valido dos pequenos formatos para que fosse possível captar a impressão do instante.

Vale aqui fazer um parênteses para constatar que, no caso de nossas paisagens do rio Pinheiros, a pequena dimensão das matrizes de gravura também é um fator que propicia o trabalho em campo, especialmente nas etapas iniciais, em que são traçadas as linhas principais que definirão a estrutura geral da composição. Em um segundo momento, registros rápidos de observação em aquarela propiciam estudos para o trabalho com os valores tonais e manchas de cinza e preto. A fotografia acaba por ser indispensável ao processo, uma vez que, diferente da pintura, a gravação com água forte e água tinta é um processo indireto, feito em ateliê. mas os estudos em campo auxiliam à produção de um registro mais sintético das luzes e sombras.

"As primeiras paisagens modernas eram excessivamente pequenas - cerca de cinco por sete centímetros. Foram executadas entre 1414 e 1417, num manuscrito 
Ao lado [imagem 21], Detalhe inferior do Batismo de Cristo, em Horas de Turim, atribuído a Hubert van Eyck

https://en.wikipedia.org/wiki/Turin-Milan_ Hours\#/media/File:Eyckbaptism.png
Van Eyck teria sido precursor, em vários séculos, do desenvolvimento do gênero, à medida que "[...] conseguiu com a cor uma sensação de saturação de luz. $\mathrm{O}$ tom da paisagem tem uma sutileza que dificilmente se observa novamente até ao século XIX, e o reflexo do céu do entardecer na água é exatamente a espécie de efeito que se tornaria parte da iconografia popular dos últimos cem anos." ( 1961, p. 37)

Clark emite juízos que levam a crer que sua predileção pelos efeitos etéreos da luz relega a segundo plano o motivo e as figuras da paisagem, o que revela muito de sua filiação enquanto crítico de pintura, trazendo o contexto modernista de sua formação. Sua referência para a qualidade pictórica das paisagens parece ser a do Impressionismo. Clark atribui, assim, à característica "imaginativa", que resulta da busca de captar as impressões da luz em movimento, a qualidade verdadeiramente estética das pinturas de paisagem. $\mathrm{Na}$ passagem a seguir, expressa-se bem o sentido que o autor atribui como qualidade moderna das paisagens:

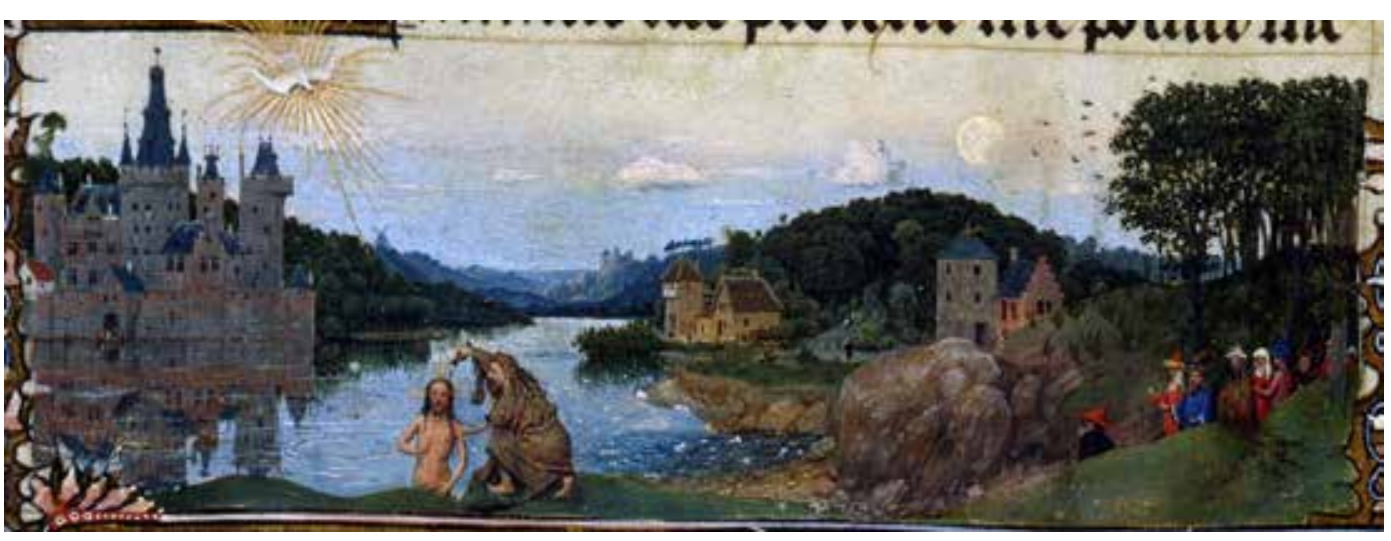




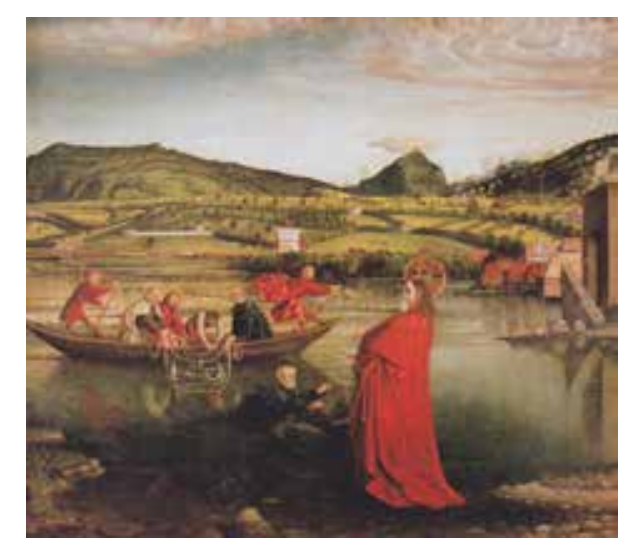

Acima [imagem 22], Konrad Witz, The Miraculous Draft of Fishes, $1444.132 \mathrm{~cm} \times 154 \mathrm{~cm}$, Musée d'Arte et d'Histoire, Geneva.

Fonte: https://en.wikipedia.org/wiki/The_Miraculous_Draft_of_Fishes_(Witz)

Ao lado [imagem 23], Albrecht Dürer, detalhe daVista de Innsbrück, , aquarela, 127 x 187 mm, 1495. https://commons.wikimedia.org/wiki/File:Albrecht_D\%C3\%BCrer_-_View_of_Innsbruck_-WGA7356.jpg
"A paisagem, quando a alcançamos, é de miragem, e a interpretação da luz é mais delicada. A paisagem é para o pintor flamengo mais ou menos o que a representação do movimento é para o florentino. Aumenta o nosso sentido de bem-estar, alargando o alcance das nossas percepções físicas. Proporciona-nos um espetáculo mágico." (1961, p. 38)

Por outro lado, Clark nos introduz a um gênero que chama negativamente de "topografia", um subgênero da sua ideia das "paisagens dos fatos". Konrad Witz seria o precursor desse tipo de paisagem, e, para o historiador, a primeira topografia expressa o espírito de artistas que são “[...] obcecados pela estranheza de algumas formas, e tendem a deixar-se absorver pela representação literal de certos temas como uma espécie de fuga aos seus sonhos obsessivos."(1961, pp.39-40)

É nítida e contundente a abordagem negativa de Clark em relação ao que ele caracteriza como meramente topográfico e, consequentemente, desprovido de qualidades propriamente estéticas: Albrecht Dürer seria também alvo de suas críticas, a exemplo das aquarelas, que

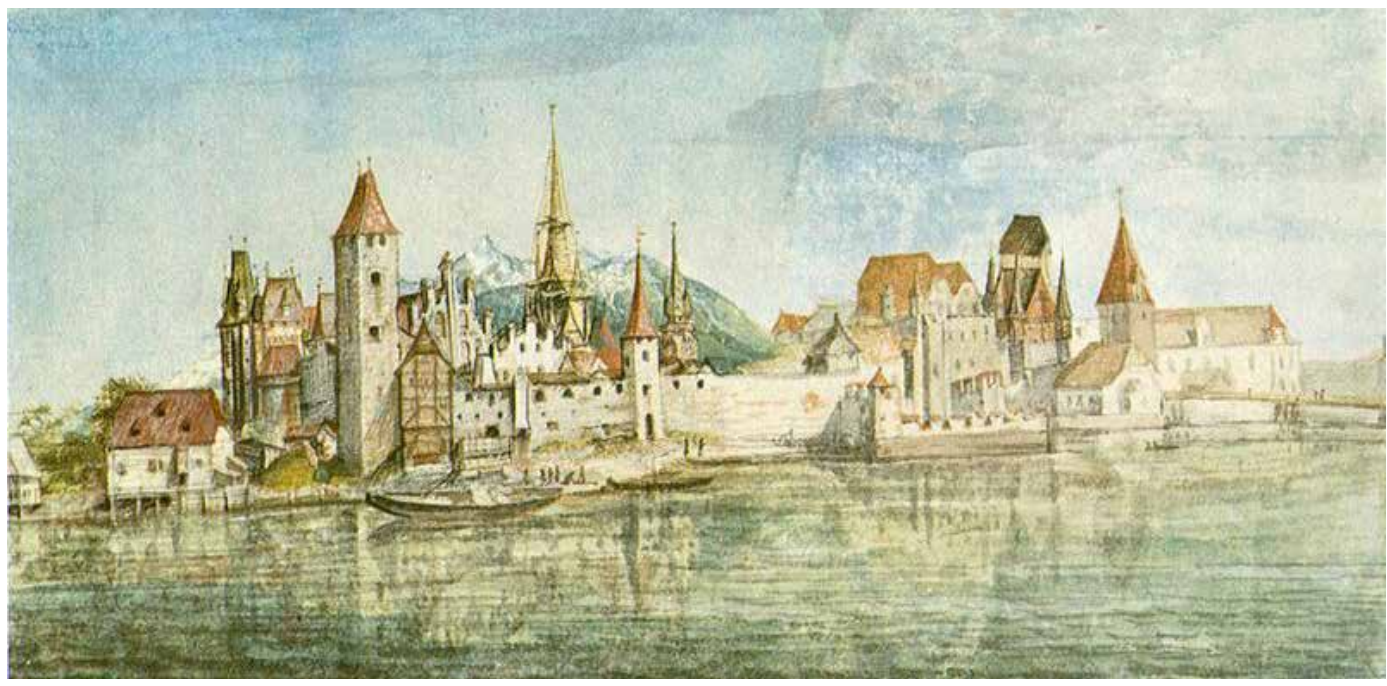




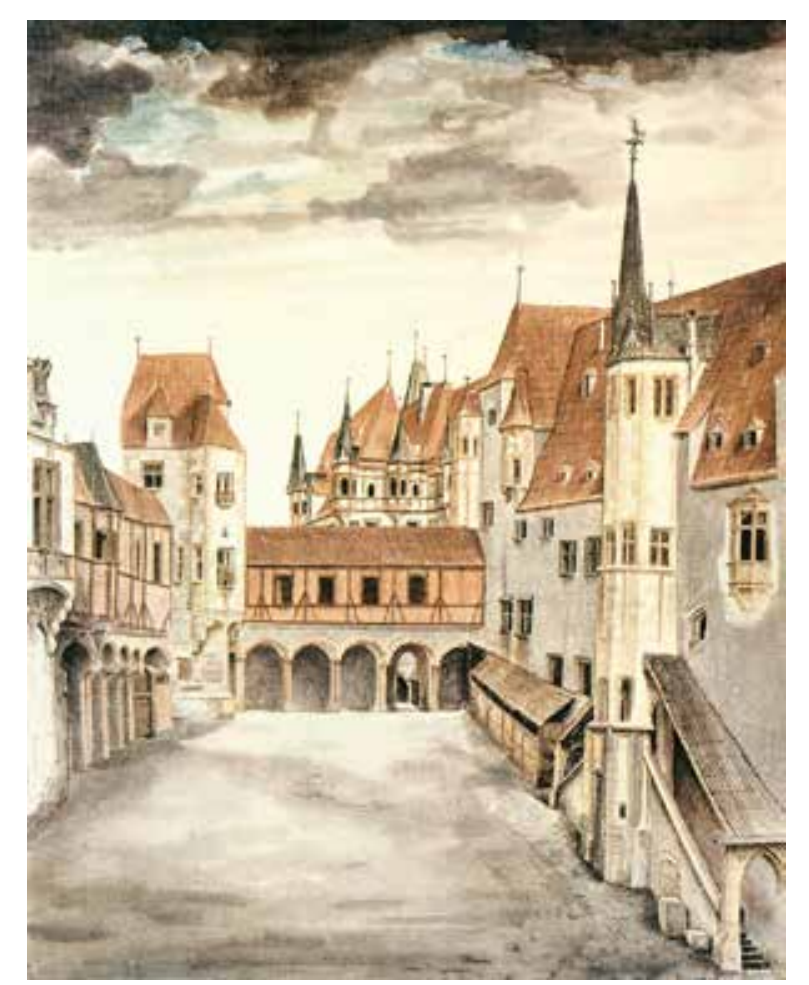

Acima [imagem 24], Albrecht Dürer, Pátio do Castelo de Innsbruck com nuvens, cerca de 1496, aquarela, guache e pena sobre papel. Albertina, Vienna.

Fonte:https://www.nga.gov/content/dam/ngaweb/ exhibitions/pdfs/durer.pdf
“[...] caracterizam-se por um desenho, que com a ânsia de representar o máximo de pormenor, parecem o trabalho de um pintor amador. Mas alguns meses mais tarde, Dürer executou a aquarela de Innsbrück, agora em Albertina, que não é só a primeira representação exata de uma cidade, mas mostram uma delicada percepção da luz. Os desenhos do Castelo de Innsbrück, executados no mesmo tempo, são pura topografia, e na realidade as paisagens em aquarela da Dürer são mais notáveis pela curiosidade e habilidade do que por aquelas qualidades a que hoje chamamos estéticas." (1961, p. 40)

A respeito das paisagens dos fatos, a teoria de Clark nos diz que a especificidade dos pintores do Norte se baseia em um olhar empírico para os aspectos da luz, em contraposição ao olhar analítico italiano:

\begin{abstract}
“[...] uma das condições da paisagem dos fatos era um novo sentido de espaço. Isto aparece simultaneamente na arte flamenga e na italiana, mas, se bem que produzindo um resultado semelhante, é diferente nos meio e intenção. Em van Eyck é instintivo, um subproduto da percepção da luz, e em toda a evolução da pintura flamenga mantémse empírica. Ora esta representação empírica do espaço, este traçado como que num écran transparente, preenche as necessidades da pintura naturalista. Mas esta não podia satisfazer a mentalidade matemática dos florentinos. Estes exigiam, nas palavras de Luca Pacioli, que a arte se apoiasse em certezze, e não em opinioni, e era sua opinião que tais certezze só podiam ser estabelecidas pela matemática. A sua definição de real era aquilo que se provasse ocupar uma dada posição no espaço." (1961, p. 40-41)
\end{abstract}

Mas esta característica geral atribuída aos italianos não é simples ou absoluta: havia a consciência das limitações da perspectiva, e há lugar para o incerto também no olhar florentino. Ao nos contar a conhecida anedota da pintura da Piazza de San Giovanni de Brunelleschi, o autor nos coloca que, apesar das certezze que a perspectiva proporcionara ao pintor-arquiteto florentino, “[...] havia um elemento da paisagem que não podia ser dominado: o céu. O fluxo contínuo de diferentes aspectos do céu só pode ser 


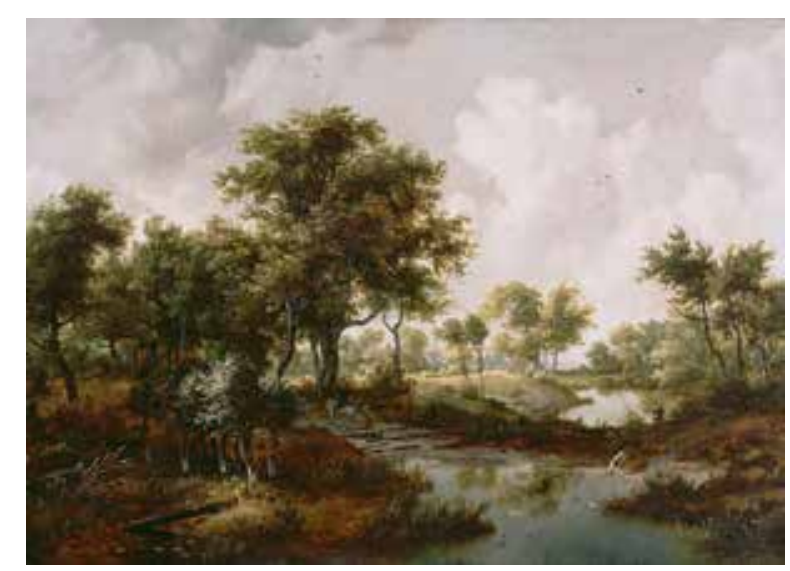

Acima [imagem 25], Meindert Hobbema, $A$ Wooded Landscape, Getty Center, 1667.

Fonte:https://en.wikipedia.org/wiki/Meindert Hobbema

7. É dado ao céu sempre um lugar de destaque na questão da representação da paisagem, e os motivos para tanto parecem autoevidentes, mas é curioso como Brunelleschi, em sua demonstração científica da perspectiva geométrica, teria se utilizado de um recurso inventivo do ponto de vista da construção do objeto artístico: colocar um espelho no lugar do céu sobre um desenho geométrico do espaço objetivado. sugerido de memória e não determinado pela matemática. E Brunelleschi, reconhecendo perfeitamente as limitações da sua teoria, não tentou pintar o céu ao fundo da sua Piazza, mas substituiu-o por uma peça de prata polida." (1961, p. 41) ${ }^{7}$ O protagonismo dos céus se reafirma, então, como uma qualidade singular da paisagem, que resiste à objetivação:

Clark afirma, assim, que haveria uma particularidade nos céus holandeses que teria inspirado os primeiros mestres das paisagens. A passagem que segue demonstra bem a sua crítica dirigida ao exagero descritivo dos fatos da paisagem. A tentativa de se particularizar a incidência da luz sobre cada uma das coisas que habitam a paisagem seria vã, e o artista deveria optar pela busca de sintetizar um "princípio geral" da luz para conseguir transmitir uma sensação luminosa de forma poética. O crítico afirma que qualquer pintor, mesmo que de "segunda ordem ", mas que pintasse o céu e o mar, poderia nos encantar, enquanto que obras de um pintor hábil como Hobbema, com árvores muito pormenorizadas e que não se subordinam ao princípio da luz, provocam algum tédio ( 1961, p. 53)

Mas qual seria este princípio geral da luz ao qual as árvores não se subordinam? Clark parece nos dizer que, à medida em que os detalhes se pronunciam, a exemplo da luz refletida em cada folha das árvores, a paisagem deixa de contemplar a dramaticidade da luz. O céu pintado por Hobbema na imagem abaixo é de fato deixado de lado ante o detalhamento da luz sobre as árvores, mas não parece ser isto o que torna a imagem "tediosa”. Seria talvez uma imobilidade, algo de estático e afásico nas luzes de Hobbema o que 
tornaria suas paisagens entediantes?

A relativização da perspectiva científica prossegue quando o autor nos coloca que o caráter da perspectiva abstrata não era totalmente compreendido até na Florença do século XV, afirmando ainda que mesmo Alberti oscilava entre a tentativa matemática e a realista de conhecimento das aparências, não reconhecendo, portanto, que tais atitudes são incompatíveis (1961, p.42)

É importante notar que há uma divisão de categorias quando Clark refere-se à "tentativa matemática", e a "tentativa realística" de se conhecer as aparências. Para Clark, os italianos viveram a tentativa de conciliar as duas atitudes para pintar as paisagens, mas os resultados eram paisagens sem a mesma naturalidade desenvolta, intuitiva e precisa do olhar flamengo. Nesse sentido, o autor reconhece nos flamengos o que seria uma expressão positiva da atitude "topográfica":

"[...] um sentido muito elevado de topografia que se baseia numa curiosidade e agudeza de visão suficientemente importante para tornar a paisagem na pintura tão importante como o nu. Mas por muito boa que seja uma paisagem de fundo de Pollaiuolo, não foi superada a dificuldade de uma suave transição para o espaço que Hubert van Eyck resolvia instintivamente." (1961, p. 42)

Tal dificuldade se explicaria pela tentativa italiana de unir o modelo matemático de perspectiva com o que modelo da observação que Clark chama "realista". A superioridade flamenga no tratamento da luz, reconhecida e assimilada pelos florentinos, atesta completamente a contribuição do Norte na pintura do Quattrocento italiano. Mas, para Clark, teria sido na Veneza de Giovanni Bellini, e não em Florença, que as lições dos Van Eyck teriam sido melhor compreendidas e desenvolvidas. Sua relação com Antonello da Messina pode ter lhe trazido muito da técnica dos Van Eyck, uma vez que ele teria sido, segundo Petrus Cristus, o verdadeiro herdeiro da escola flamenga. 
Para que possamos refletir sobre o significado da paisagem dos fatos, é importante observar a centralidade de Bellini na análise de Clark: o louvor às sutilezas da luminosidade é sempre o que permeia o desejo de observar e reproduzir os mínimos pormenores do mundo visível. O que Clark busca ressaltar como o mais importante dom que Bellini possuía, e que o coloca como um dos maiores paisagistas de seu tempo, é “[...] uma reação

Ao lado [imagem 26], Giovanni Bellini, São Francisco no deserto, cerca de 1480 , óleo e têmpera sobre madeira, $124.4 \times 141 \mathrm{~cm}$

Nova Iorque, FrickCollection

Fonte:https://courtauld.ac.uk/event/giovanni-bellini-and-the-poetics-of-viewing

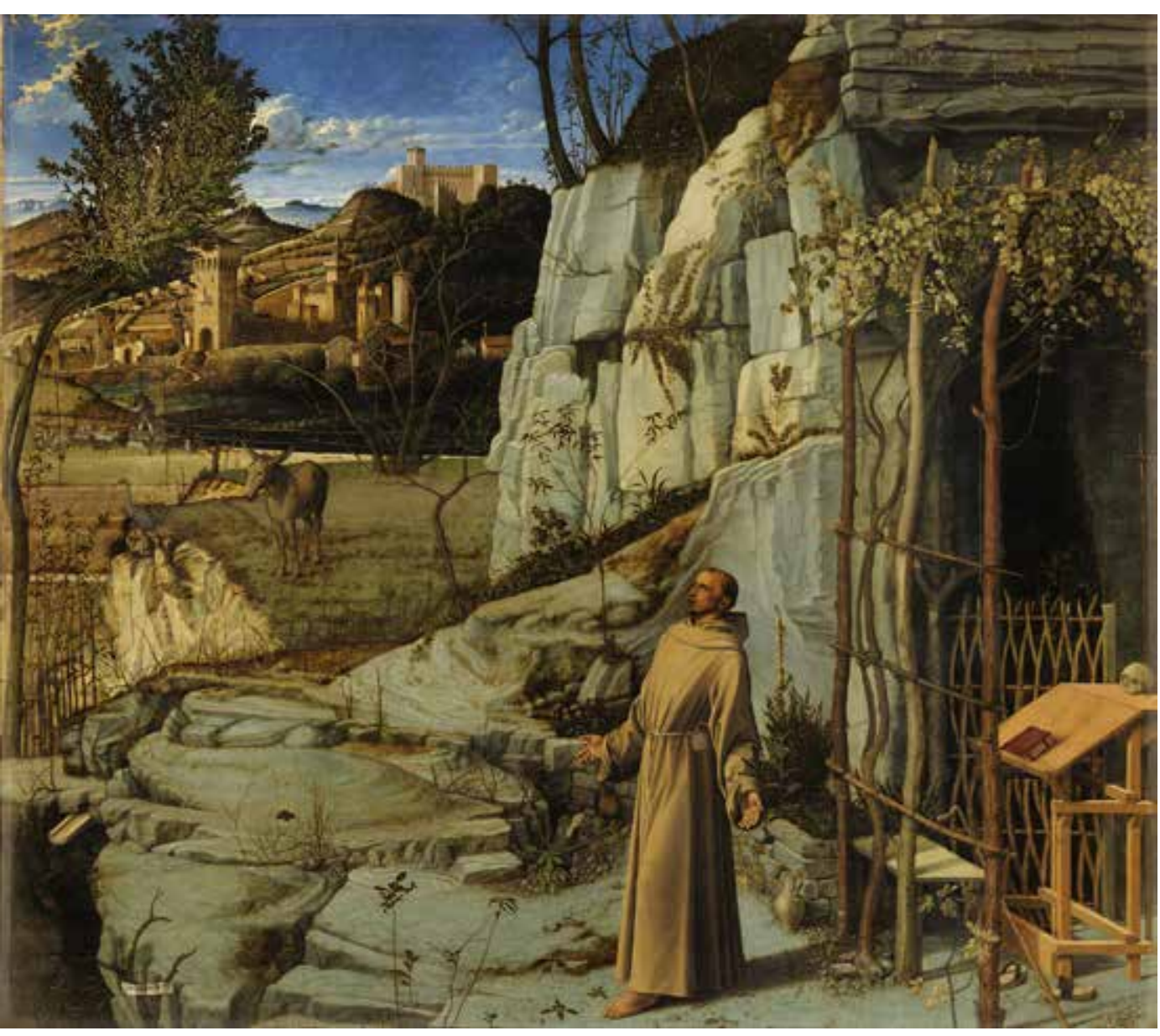


emocional à luz.[...] Mesmo no período em que a habilidade manual e firmeza de opiniões pareciam ser a última palavra em arte, Bellini faz do efeito de luz o motivo principal da sua pintura." (1961, p. 44)

A observação de Bellini é caracterizada como "desapaixonada”, mas ao mesmo tempo o autor diz que o pintor traduzia os fatos pelo amor: "Poucos artistas foram capazes de um tal amor, que abarca cada ramo de árvore , cada pedra, o mais ínfimo pormenor, assim como a mais grandiosa perspectiva, e apenas pode ser conseguido com uma profunda humildade."(1961, p. 45)

A ideia de Clark de um "amor desapaixonado" pelos fatos e detalhes luminosos da paisagem explicita muito bem a discussão sobre o registro obsessivo dos fatos em oposição à imaginação poética nas paisagens. O verdadeiro artista seria aquele capaz de contemplar todos os detalhes do mundo com o mesmo louvor, sem que se deixasse levar pela racionalização de imagens da sensibilidade literária e da sua afetividade subjetiva relativa a um ou outro detalhe específico. Sua opinião é explicada a exemplo da hierarquia dos poetas definida por Ruskin em seu Modern Painters: Bellini pertencia à mais alta classe dos poetas, que são capazes de perceber corretamente um fato sem deixarem-se levar pelos sentimentos e afetividades associadas a esse fato, capaz de sentir sem elaborar tal sentimento para além dos fins de sua pintura.

Aparentemente, Clark compartilha com Ruskin uma clara separação entre o "perceber" e o "sentir", segundo a qual uma percepção incorreta de um fato decorreria de uma sensação que se mistura à percepção, trazendo à tona algo "a mais" implícito em tal fato. Compreende-se aqui que a categoria mais elevada de Ruskin seria, portanto, aquela que é capaz de ser um meio-termo entre aquele que só percebe, mas é incapaz de sentir, e por isso fica aquém da poesia, e aquele que sente mais do que percebe, e por isso acaba por se distanciar dos fatos. O ápice dessa atitude de amor à luz em Bellini seria o seu São Francisco. 
Esta oposição colocada por Ruskin e endossada por Clark possui diversos desdobramentos. A questão da separação entre sensação e percepção é um marco na teoria da paisagem no século XX, e se expressa principalmente pelo neuropsiquiatra Erwin Straus. Em seu livro "O sentido dos sentidos" (VomSinn der Sinne $e^{8}$ ), publicado em 1935, o autor opõe, em relação à experiência sensível do espaço, a percepção à sensação, referenciado numa oposição análoga entre geografia e paisagem. Em relação a essa oposição, Jean-Marc Besse, no quinto ensaio de seu Ver a Terra', observa:

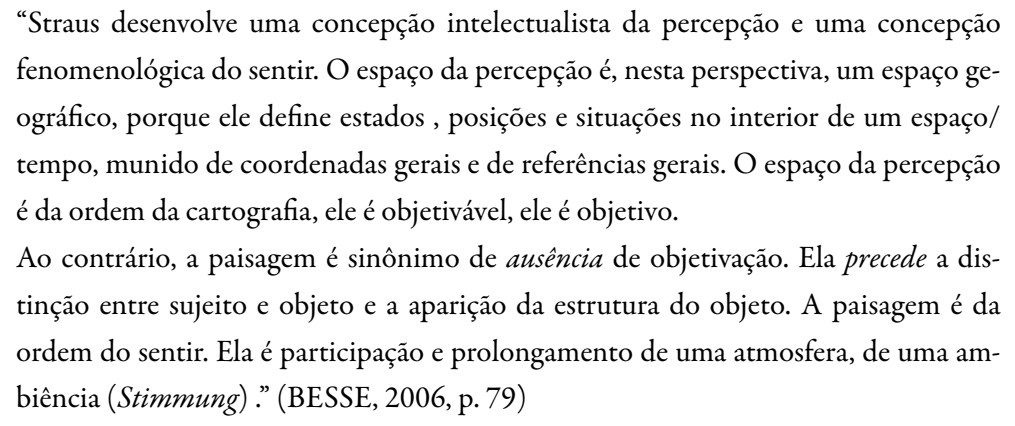

"Straus desenvolve uma concepção intelectualista da percepção e uma concepção fenomenológica do sentir. O espaço da percepção é, nesta perspectiva, um espaço geográfico, porque ele define estados , posições e situações no interior de um espaço/ tempo, munido de coordenadas gerais e de referências gerais. $\mathrm{O}$ espaço da percepção é da ordem da cartografia, ele é objetivável, ele é objetivo.

Ao contrário, a paisagem é sinônimo de ausência de objetivação. Ela precede a distinção entre sujeito e objeto e a aparição da estrutura do objeto. A paisagem é da ordem do sentir. Ela é participação e prolongamento de uma atmosfera, de uma ambiência (Stimmung)." (BESSE, 2006, p. 79)

8. STRAUS, Erwin. Da diferença entre o sentir e o perceber - texto correspondente ao capítulo VII de Le sens des sens. Contribution à l'etude des fondements de La psychologie. Trad. do original alemão por G. Thines e J.-P. Legrand. Grenoble: Jerome Millon (orig.: Berlim, 1935) In: PAISAGEMTEXTOS-vol. Trad. e org. Vladimir Bartalini. FAUUSP. São Paulo. 2013. p. 58-59

9. BESSE, Jean Marc, Ver a Terra - seis ensaios sobre a paisagem e a geografia - São Paulo : Perspectiva, 2006
Essa discussão reverbera a todo momento em nossa busca pela paisagem do rio Pinheiros: a princípio nossas paisagens parecem ocupar-se muito mais daquilo que Straus chamaria de percepção e de geografia do que da paisagem, o "sentir". Se uma atmosfera ou uma ambiência da luz está presente, é sempre em harmonia com os fatos da paisagem, ou talvez resultante de sua descrição. Assim, tendemos sempre a procurar um caminho do meio entre tais dualidades opostas. E, em nosso caso, uma fenomenologia mais adequada à percepção da luz e da paisagem seria aquela de Merleau-Ponty (2011, pp. 23-34), em que as noções de sensação e percepção não se excluem mutuamente. Para ele, a sensação já nos traz o percebido, pois o modo como as coisas se doam aos nossos sentidos já é percepção, e, por isso, já compreende uma síntese perceptiva anterior a qualquer reflexão e 
objetivação, revelando que as coisas percebidas possuem sentido e conteúdo no seu próprio modo de estar no mundo e de solicitar o nosso olhar, não sendo representações que delas constituímos na consciência; nem sendo uma sucessão de causalidades mecânicas que fariam de nossos sentidos, corpos, cérebros e percepções, meros feixes de funções físicoquímicas, fisiológicas, determinadas por fatos externos.

Por outro lado, ecos de uma outra oposição dual reverberam sobre a representação da paisagem e se colocam para a história da pintura: a da arte do Sul e do Norte da Europa. Diferentemente da pintura descritiva do Norte, a tradição narrativa, retórica da paisagem teria persistido na pintura italiana e, segundo nos conta Clark, a paisagem dos fatos teria desaparecido da Itália depois de Bellini e Pollaiuolo, voltando somente em meados do século XVII; "A paisagem devia conter qualquer associação literária, ou conter uma cenografia que intensificasse o efeito dramático." (1961, p.46)

A preponderância do efeito heróico no estilo renascentista italiano advinha da escultura antiga, colocando o corpo humano como "meio de expressão onipotente". Teóricos da arte enalteciam a importância moral ou histórica do tema na obra de arte, de tal modo que até Michelangelo teria sido um dos principais inimigos da paisagem, contrapondo-a ao seu ideal de arte baseado na escultura clássica, sem contar a rivalidade geopolítica com as invenções da arte flamenga:

“'Eles pintam na Flandres', disse ele a Francisco de Holanda, 'apenas para enganar a vista exterior, coisas que alegram e que são saudáveis. Pintam ninharias, tijolos e argamassa, a erva dos campos, a sombra das árvores, pontes e rios, a que eles chamam paisagens, com pequenas figuras aqui e ali. E tudo isto, se bem que possa parecer bom a alguns olhos, é na verdade feito sem razão, sem simetria ou proporção, sem o cuidado de escolher ou rejeitar'. Miguel Ângelo embebido no neoplatonismo e lutando perpetuamente por um ideal de arte tão forte e exaltado que os meros prazeres da percepção lhe pareciam desprezíveis, certamente encararia os prados floridos de Gherard David e os panoramas de Patinir como próprios para ( como ele próprio 
Resumidamente, Clark constrói o fio narrativo de uma história da "paisagem dos fatos" pela via da comparação entre a arte renascentista dos pintores do Norte em relação à pintura italiana. Um tipo específico de imagem, em que vemos a transcrição minuciosa do espaço e do mundo visto tomando a frente da retórica das imagens, passa a ser difundido e valorizado pela Europa. A perspectiva, como o próprio autor nos diz, não impõe seu peso histórico no modo de operar dos artistas flamengos. É certo que eles conheciam "perspectivas", e empregavam métodos de organização perspéctica do plano visual, mas estes conhecimentos eram para eles mais recursos de trabalho do que um sistema absoluto da construção espacial.

A hipótese de Clark é a de que um gosto singular, culturalmente enraizado, pela observação dos fatos e da luz, teria dotado a tradição holandesa de pintura de paisagem de uma intuição, uma relação "instintiva” coma observação da luz e das atmosferas. Pela observação direta do espaço e pela prática do desenho e da pintura dentro e fora do ateliê, o nível de sofisticação da linguagem poética de representação dos fatos da paisagem estruturou modelos empíricos que dispensam a perspectiva científica. Os resultados obtidos pelo olho e pincel flamengos superam os da construção perspectiva italiana em termos de ilusionismo, realismo e verossimilhança.

Entre outras razões, o desfecho da paisagem dos fatos ocorre, segundo Clark, quando as "topografias" desse olhar holandês, que teria atingido seu apogeu no século XVII, passaram a se tornar cada vez mais banais e inexpressivas, um mero "ofício de artesão", uma técnica auxiliada pelas lentes e processos proto-fotográficos em voga.

O que nos interessa aqui é analisar até que ponto se sustenta esta imbricação quase inescapável entre a suposta "invenção da perspectiva no renascimento" e a "invenção da 
paisagem". Para tanto, apoiaremo-nos em Svetlana Alpers ${ }^{10}$, que analisa um aspecto deixado de lado por Clark na sua categoria da paisagem dos fatos. Mais do que um gosto pela luz, pelas nuances e pormenores do visível, havia nas paisagens dos fatos holandesas o que Alpers chama de "impulso cartográfico", uma outra relação entre as imagens e o mundo visto.

\section{A paisagem como descrição}

É interessante notar que, no desejo pela paisagem, concorrem uma componente de liberdade e uma de dominação. Há nesse desejo um misto de entregar-se à experiência da natureza e de possuir uma porção da terra, sem necessariamente o desejo de habitá-la. O lugar contemplativo da paisagem pode estar em nos apropriarmos de particularidades de um território, reunindo-as e articulando-as em um suporte virtual, de modo que remetam a uma totalidade inabarcável.

Da mesma maneira, a contemplação da paisagem pode ser também o ato de sair de si, e se deixar passear pelo mundo cujas referências não conhecemos. A geografia, entendida no seu sentido de grafia, como inscrição ou escrita, comporta tanto o espírito da aventura, do encantamento pelo mundo, quanto a sua dominação, a demarcação do território e do habitat. É precisamente esta dualidade entre nomadismo e sedentarismo, que se expressa em exemplos da história da paisagem, desdobrada de uma infinidade de outras dualidades, que procuramos relativizar ao longo do fio condutor desta pesquisa.

O mote do registro, o intuito de abarcar uma certa extensão de território, descrevendo-a segundo vistas discretas, transparece nas imagens das margens do rio Pinheiros. Há um desejo expresso de mapear, ainda que sem uma cartografia sistemática, 
uma porção da paisagem que se dá em função dele. Os fragmentos dela, as vistas coletadas, relacionam-se entre si, não somente pelas suas semelhanças e assunto, mas por uma linha narrativa correlata a uma linearidade espacialmente configurada à margem do rio. E essa linha pode ser entendida como o todo de um "mapa", um plano de representação que contém informações mais ou menos gerais, específicas e variadas sobre um território.

Se há nas imagens da paisagem do rio Pinheiros um interesse explícito pelas especificidades da luminosidade, pelas texturas e pelos pormenores, ou seja, os "fatos" da paisagem, ele concorre com uma pretensão totalizante, a busca de descrever pelo acúmulo de tais "fatos" ou informações visuais, algo de uma qualidade geográfica específica que engloba esta paisagem.

Longe de buscar, nos exemplos da arte flamenga dos séculos XV a XVII, conceitos historiográficos convenientes à linguagem de um projeto artístico, debruçamo-nos sobre este episódio da pintura de paisagens no sentido de identificar traços da história da arte cuja sobrevivência se manifesta aqui e ali, em maior ou menor quantidade, nas imagens ditas "de paisagem" até hoje. Seja em relação às paisagens do rio Pinheiros, ou à arte contemporânea em geral, a história da arte nos ajuda a elencar critérios de apreciação para ler as imagens.

\section{O impulso cartográfico}

A respeito do que chama de "impulso cartográfico", Svetlana Alpers define tal conceito como a coincidência entre cartografar e pintar, baseada em "[...] uma noção de conhecimento e crença comum que deve ser adquirida e afirmada através da pintura." (ALPERS, 1999, p.241) Mais do que confirmar o que já vimos, o modelo é, ele próprio, uma imagem; as características descritivas são fundamentadas “[...] diretamente na na- 
tureza das atitudes para com um tipo particular de imagem e a linguagem a ela aplicada." (1999, p. 242)

As características cartográficas da arte holandesa do século XVII teriam, então, sido fruto de uma convergência no papel das imagens, reunidas em torno do propósito da descrição gráfica do mundo, em consonância com o protagonismo holandês no âmbito das navegações e do comércio exterior. A característica de expansão e difusão das técnicas gráficas colocou a Holanda em intercâmbio com estampas da arte oriental; havia uma cultura tipicamente burguesa das imagens em gestação, e esta seria uma das razões sócio-econômicas para a aproximação entre a cartografia, o texto e a pintura holandeses.

É evidente a presença de uma raiz desta atitude de registrar a coisa vista fundada no trabalho e nas necessidades práticas. As transformações na Europa do século XVI trazidas pelas operações militares, comércio e gestão da água impulsionaram a ilustração geográfica nos Países Baixos. Cresce a “[...] confiança nos mapas como forma de conhecimento e um interesse nos tipos particulares de conhecimentos a serem extraídos dos mapas." (1999, p. 254)

O louvor à cultura gráfica e cartográfica é exemplarmente expresso em $A$ arte de pintar de Jan Vermeer. Interpretada na história da arte como comentário sobre a vaidade e as preocupações humanas, a obra coloca, além disso, o mapa como uma “[...] peça de pintura por direito próprio" (1999, p.243). Se comparada a outras pinturas da época que também retratam mapas, nota-se que nela o mapa assume muito maior protagonismo, presença pictórica e riqueza de detalhes. Impresso com todas as técnicas gráficas presentes na época, o mapa era "Em tamanho, escopo e ambição gráfica, [...] uma súmula da arte cartográfica da época, representada na pintura de Vermeer.” (1999, p.244) 


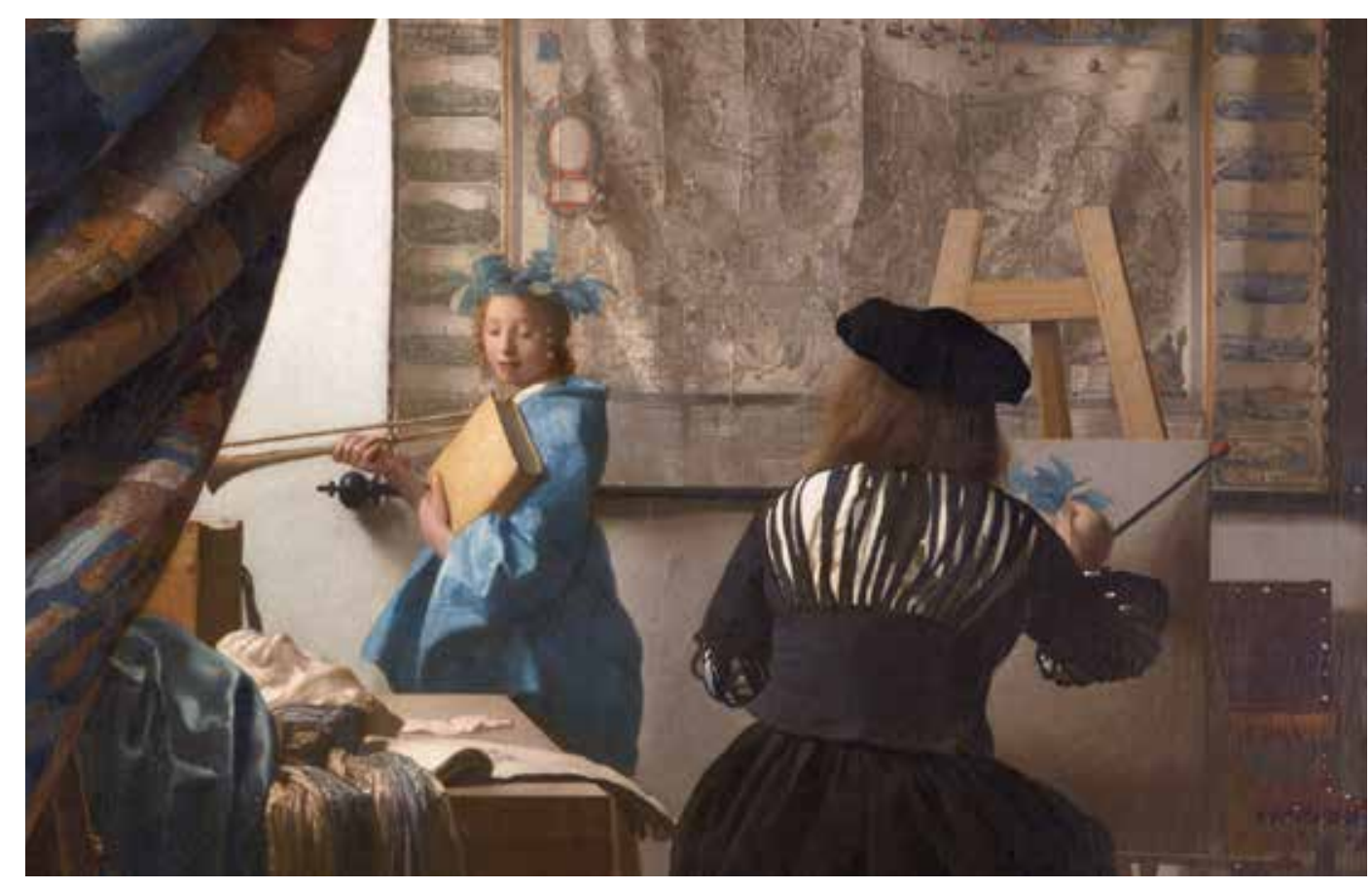

$\mathrm{Na}$ leitura de Alpers, nessa emblemática pintura, "tudo tem um estatuto paradigmático": o mapa apresentado como pintura corresponde a uma noção de pintura. A palavra "descriptio" aparece na borda superior do mapa: mapistas eram chamados "descritores do mundo", embora o termo, segundo a autora, nunca tenha sido aplicado às pinturas e pintores.

Ao lado [imagem 27], Jan Vermeer, $A$ arte de pintar (detalhe), c. 1666-1668, Museu de história da arte de Viena.

Fonte: https://www.wikiart.org/pt/johannes-vermeer/a-arte-da-pintura-1668
"O objetivo dos pintores holandeses era captar, sobre uma superfície, uma grande quantidade de conhecimentos e informações sobre o mundo. Empregavam também palavras com suas respectivas imagens. Como os cartógrafos, faziam trabalhos adicionais que não podiam ser compreendidos de um ponto de vista único. $\mathrm{O}$ deles não era uma janela, segundo o modelo de arte italiano, mas, sim, como um mapa, uma 
Segundo Alpers, a cartografia não seria apenas um análogo para a arte de pintar dos holandeses. Ela sugere "certos tipos" de imagens relacionados a "certas tarefas" a serem cumpridas pelos artistas. A famosa Vista de Delft confirma a reprodução de um “[...] esquema comum inventado para as vistas topográficas de cidades no século XVI[...] "Vermeer repóe a cidade pintada no contexto cartográfico do qual ela emergira, como um reconhecimento de sua natureza." (1999, p.249)

A propósito desta proximidade da pintura de paisagem com a criação de mapas, Alpers ressalta que há uma tendência contemporânea tanto no campo acadêmico quanto no artístico. A autora aponta que a história da arte de hoje inclui muitos artefatos cartográficos, além de obras tradicionais no seu estudo.A arte contemporânea traz inúmeros exemplos de mapas como obra de arte, além de pinturas que se inspiram em mapas, vide, por exemplo, a série de pinturas sobre o mapa dos EUA feitas por Jasper Johns. ${ }^{11}$

Um dos exemplos históricos desta convergência entre o trabalho do mapista e do pintor foi o empreendimento de mapear uma região dos EUA com litografias no século XIX: paisagens do oeste do país foram descritas para fundamentar as escolhas do plano da rota ferroviária:

11. Cf. HARMON, K. The map as art : contemporary artists explore cartography. New York : Princeton Architectural Press, 2009.
"Os mapas fornecem-nos a medida de um lugar e a relação entre lugares, dados quantificáveis, enquanto as pinturas de paisagem são evocativas e visam dar-nos certa qualidade da percepção que o observador tem dele. Um está mais próximo da ciência, o outro é arte. Essa visão geral, embora casualmente adotada - casualmente porque em geral não procura o fundamento filosófico possível - , é sustentada profissionalmente. Os cartógrafos constituem um grupo claramente distinto dos artistas, assim como os estudiosos da cartografia se distinguem dos historiadores da arte. Ou, pelo menos, era 
Os mapas decorativos, embora muito estudados e difundidos entre os cartógrafos, seriam dotados, segundo eles, de menor cientificidade devido a tal componente artística. Alpers demonstra que há indefinição entre o que é considerado científico e o não científico na concepção de tais geógrafos, pois eles não levam em conta o espírito científico da época, que guiava o empreendimento de um mapa como um todo, que incluía a sua componente decorativa em um objeto de caráter científico.

De maneira geral, segundo a autora, "Para os holandeses não haveria essa fronteira tão clara entre mapa e arte. Pois numa época em que os mapas eram considerados um tipo de pintura, e em que as pinturas desafiavam os textos como uma maneira fundamental de compreender o mundo, a distinção não era nítida."(1999, p.253) O que Alpers quer enfatizar é que os estudiosos da cartografia e os geógrafos deveriam se interessar mais pelas semelhanças e sobreposições entre as duas formas de registro do que buscar estabelecer as fronteiras que as dividem.

A autora nos traz a fala de Ronald Rees, de 1980, que ilustra tal concepção: “a execução de mapas como forma de arte decorativa pertence à fase informal, pré-científica da cartografia. Quando os cartógrafos não tinham nem o conhecimento geográfico, nem a habilidade cartográfica para produzir mapas precisos, a fantasia e a arte galopavam à rédea solta." (1999, p. 253)

A autora concorda em parte com o que diz Ronald Rees, mas com a ressalva de que tal declaração não compreende a “[...]cartografia pré-científica em seus próprios termos, no espírito em que ela era feita”. Há na fala de Rees um índice de uma visão teleológica da ciência, em que haveria uma razão proporcional entre a evolução da cientificidade e a sua cisão com as formas artísticas. A esse respeito, Alpers prossegue: 
"Enquanto os cartógrafos põem de lado o aspecto decorativo ou pictórico dos mapas, os historiadores da arte, por sua vez, fizeram o mesmo com o aspecto documental da arte. "Mera topografia" - em contraste com "mera decoração" - é o termo que se usa aqui. Ele é utilizado pelos historiadores para classificar as pinturas ou vistas de paisagens que sacrificam a arte, ou que talvez nunca se elevem a ela, em nome do registro do lugar." (1999, p.253)

A referência é feita ao discurso de historiadores da arte como Kenneth Clark, que manifestam certa predileção por uma qualidade pouco descritiva (ou topográfica) específica das pinturas de paisagem, consideradas por ele como matéria da verdadeira arte. Clark compreende que é à medida que o pintor se distancia da literalidade descritiva da natureza, que ele consegue alcançar o nível artístico da pintura de paisagem. É possível concordar com tal noção, se a olharmos pela perspectiva da construção moderna dos valores estéticos e pictóricos. Straus (2013) concordaria com tal concepção quando nos diz que

\footnotetext{
"A pintura de paisagem não representa o que vemos, particularmente o que percebemos ao considerar um dado lugar - o paradoxo é inevitável - ela torna visível o invisível, como algo que escapa, distante. Todas as grandes paisagens têm um caráter visionário." (STRAUS, 2013, p.58)
}

A imagem é rica de significado, porém, do ponto de vista da qualidade artística de uma ou outra atitude descritiva diante da paisagem, a ideia carece de abertura, é reducionista e generalizante Sua aplicação seria possível em uma comparação da paisagem pintada por um desenhista iniciante com o artista experiente que conhece de maneira desenvolta os seus meios de expressão gráfica e pictórica; o pintor paisagista talentoso e consciente de certos preceitos estéticos seria, assim, capaz de abster-se de gastar energia transcrevendo aspectos da natureza supérfluos, para poder concentrar-se naqueles mais evocativos e de 
maior potencial poético à pintura.

O problema da fidelidade cega ao fato visual certamente se aplica à prática pictórica e gráfica e é uma das grandes dificuldades da observação e representação da paisagem: os códigos gráficos referentes aos detalhes da natureza não resultam necessariamente em boas composições, e, muitas vezes, por mais fiéis e realistas que sejam, mostram-se pouco expressivos em termos de pintura. $\mathrm{O}$ aspecto fundamental a se destacar aqui é a presença inexorável de uma escola de pintura de paisagem que estrutura o juízo de valor e alcance artístico das paisagens pictóricas e gráficas. A abordagem de Alpers, que não se detém na questão dessa tradição, olha para tais características da descrição com outros olhos, relativizando o absolutismo da tradição moderna da paisagem.

É importante à nossa pesquisa determo-nos sobre esta questão: o que significa esta visão cristalizada na história da arte, culturalmente enraizada, de que o aspecto documental da arte a sacrifica, de que é à medida que o registro da coisa vista ganha importância, que o seu valor artístico se reduz?

Não somo capazes de dar à pergunta uma resposta única, mas é possível situar o gosto e a cultura flamenga como um dos lugares em que esta visão não é claramente justificável. Havia uma ambivalência entre a função "estética" e a função "descritiva” da imagem, e o registro do fato não era, para os holandeses, algo que se sobrepunha a um ideal de arte. $\mathrm{O}$ espírito inventivo das paisagens holandesas é fruto da mútua assimilação entre diferentes funções da imagem.

Poderíamos arriscar dizer que a pintura não estava imbuída, para os flamengos, de uma mesma "aura" presente da pintura italiana para os italianos. Mas esta comparação seria grosseira, por isso é mais interessante observarmos, por outro lado, que o valor dos objetos e artefatos artísticos seriam, para a cultura visual burguesa dos holandeses, algo mais uniformemente distribuído do que a concentração em torno do valor da pintura e da 
escultura para os italianos.

Nesse sentido, Alpers atenta, então, para a "aura de conhecimento" que cercava os mapas em geral. O mapa era objeto de prestígio e exigia um alto grau de habilidade e especialização para ser produzido, sendo um tipo de imagem muito específico, assim como uma obra de arte. "Noutras palavras, dá-se muita ênfase ao valor de uma imagem. Mesmo para a pessoa do lugar, ou para o viajante em Moscou, o mapa permitia ver algo que de outro modo seria invisível. Como as lentes, os mapas eram referidos como óculos que colocam os objetos diante do olho."(id., p.263) Uma cultura de imagens tidas como objetos que dão a ver o mundo de outra forma pode ser um forte indício de uma relação menos distante e contemplativa, ou "desauratizada", das pessoas com a arte. Ou então tratava-se de uma outra aura, uma aura de intelectualidade e ilustração. O fato é que a arte holandesa ocupava um nível cultural mais próximo das preocupações cotidianas, do comércio e do trabalho, da vida burguesa protestante.

A propósito destas questões, é interessante trazermos novamente Kenneth Clark e sua narrativa da paisagem dos fatos, pois Alpers compartilha, em parte, algumas das idéias de seu precursor. Na medida em que Clark afirma que a paisagem dos fatos holandesa preconizava a paisagem moderna, ou seja, a da tradição impressionista, ele nos indaga, então, qual seria a relação causal entre a paisagem dos fatos holandesa e a paisagem impressionista:

“[...] agora que o impressionismo terminou a sua evolução, qualquer pintor que acredite que a vida do homem está ligada à natureza deve mais uma vez nela procurar sua inspiração.

Chegamos agora à paisagem dos fatos, que diretamente influenciou e até criou a visão do século XIX, a paisagem do século XVII na Holanda. Não tem semelhança com a de Brueghel e os seus pontos de contato com os fundos de Bellini e Pollaiuolo dependem apenas de uma mesma intenção, pois os pintores primitivos italianos eram inteiramente 
Clark explicita que não há uma só resposta convincente, portanto sugere três pontos de vista diversos para tentar explicá-lo: o primeiro ponto de vista, de ordem sociológica, é o de que a paisagem dos fatos, como a arte moderna impressionista, é um gênero tipicamente burguês, "[...] que refletiu o desejo de ver retratadas experiências reconheciveis."(1961, p. 50)

O segundo ponto é de ordem filosófica, e aposta na liberdade para a curiosidade científica, possibilitada ao fim da Contra-Reforma religiosa. Uma outra liberdade para a curiosidade seria também compartilhada pelo olhar impressionista.O autor menciona também a paisagem como sintoma de uma calmaria depois das guerras religiosas. Seria a necessária "distração do homem contemplativo". Com o advento das lentes, o estudo da visão e a descrição como modo de cognição, “[...] a arte antecipava-se fortuitamente ao que a ciência começava a formular.” (1961, p.51)

O terceiro ponto estaria relacionado aos movimentos internos do próprio desenvolvimento da história da arte: com o esgotamento da paisagem maneirista entre os séculos XVI e XVII, reavivou-se a paisagem dos fatos renascentista, pois “[...] o gosto holandês pela representação da coisa vista nunca tinha sido completamente abafado e mantinha-se esperando para se tornar a expandir quando a pressão da moda abrandasse. Seria contudo, um erro supor que a paisagem holandesa é admirável em proporção com o grau de objetividade que contém." (1961, p. 51-52)

Esta última sentença endossa justamente aquilo que Clark considera decadente em termos de pintura de paisagem: o "grau de objetividade", que chega ao cúmulo no século XVII na Holanda, e é a causa para o esgotamento das paisagens dos fatos. Para afirmar seu ponto de vista, o autor indica que as obras de maior valor e reconhecimento eram as paisagens que ele chama de "ideais", que não se atêm tanto aos fatos e à literalidade 


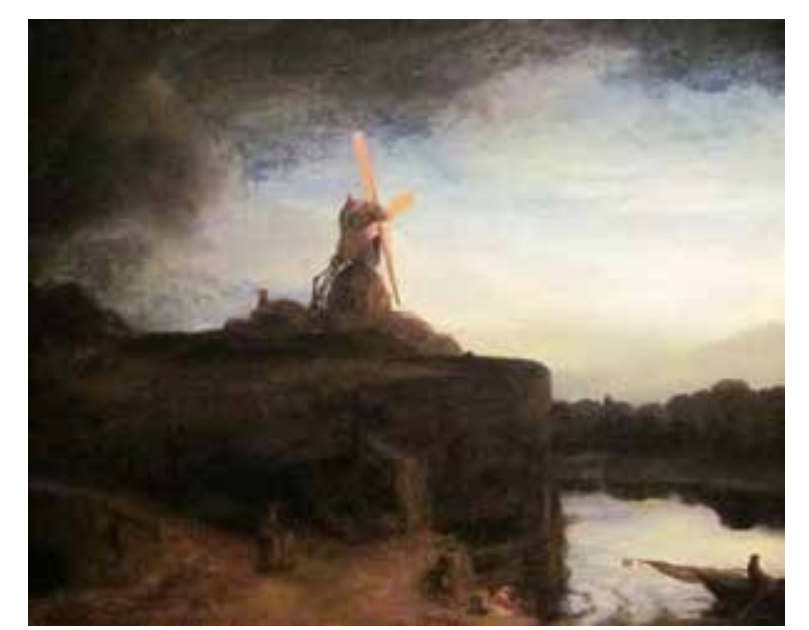

Acima [imagem 28], Rembrandt van Rijn. $O$ moinho.c.1645-48. National Gallery, Washington DC.

Fonte: https://en.wikipedia.org/wiki/The_Mill_ (Rembrandt) descritiva. Artistas como Van de Velde eram pintores de extração miniaturista, cujas paisagens concentram minúcias demasiado literais, em contraponto a pinturas como o Moinho de Rembrandt, considerada uma das melhores paisagens da época, e é, para Clark, uma paisagem ideal. Figura como grande influência o nome de Hercules Seghers, como o "grande descobridor do cenário holandês", para além de sua maestria como pintor e gravador de paisagens de fantasia, que consolidou uma tradição de paisagens de maior prestígio, pinturas livres do "vício obsessivo pelo detalhe".

A façanha de Rembrandt, entre tantas outras, seria a capacidade de abranger a paisagem factual com simplicidade, facilidade e desenvoltura sem igual, inscrevendo-a em ambiências e luminosidades atmosféricas altamente expressivas, o caráter ideal de que Clark nos fala:

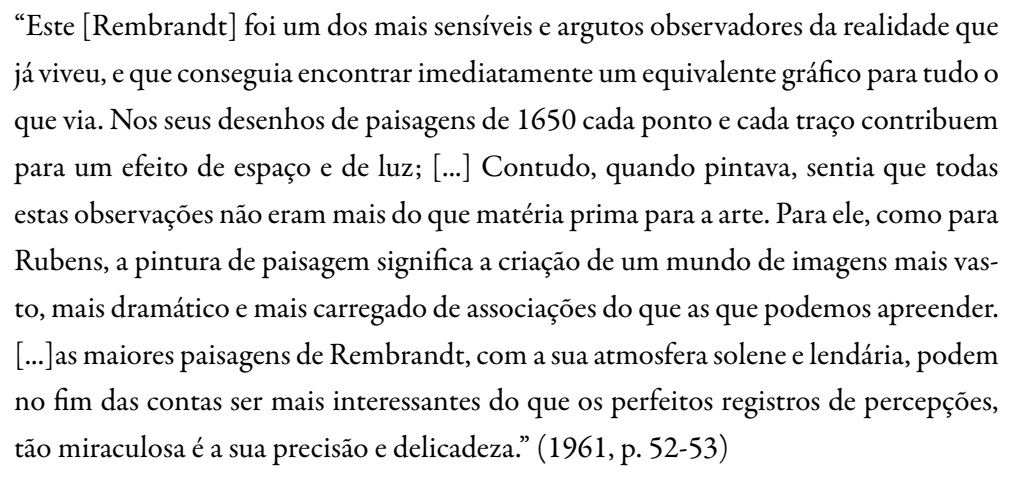

"Este [Rembrandt] foi um dos mais sensíveis e argutos observadores da realidade que já viveu, e que conseguia encontrar imediatamente um equivalente gráfico para tudo o que via. Nos seus desenhos de paisagens de 1650 cada ponto e cada traço contribuem para um efeito de espaço e de luz; [...] Contudo, quando pintava, sentia que todas estas observações não eram mais do que matéria prima para a arte. Para ele, como para Rubens, a pintura de paisagem significa a criação de um mundo de imagens mais vasto, mais dramático e mais carregado de associações do que as que podemos apreender. [...] as maiores paisagens de Rembrandt, com a sua atmosfera solene e lendária, podem no fim das contas ser mais interessantes do que os perfeitos registros de percepções, tão miraculosa é a sua precisão e delicadeza." (1961, p. 52-53)

Mais uma vez, a passagem indica que Clark qualifica, mesmo no desenho de Rembrandt, um interesse menor nos fatos e na topografia em sua vocação descritiva. Mesmo que Clark esteja correto na sua hipótese de que as paisagens ideais tinham maior prestígio, segundo podemos ler em Alpers, a mentalidade holandesa da época não compartilhava desta visão, que dissocia as qualidades descritivas do material poético das 


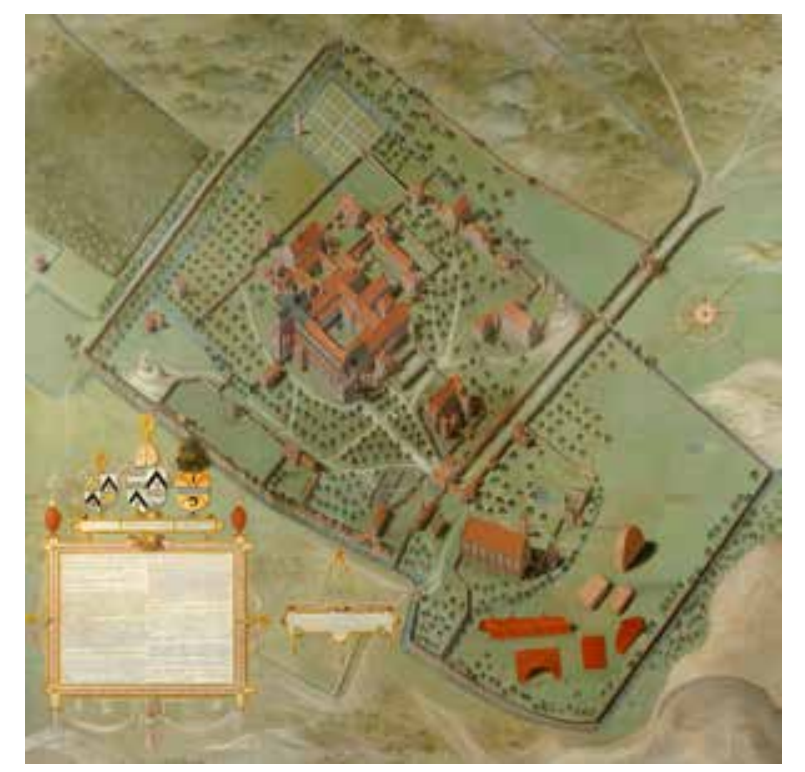

Acima [imagem 29], PieterPourbus, Mapa da abadia das dunas de Koksijde, c. 1580.

Fonte:http://vlaamseprimitieven.vlaamsekunstcollectie.be/en/collection/plan-of-the-abbey-ofthe-dunes-at-koksijde paisagens. Essa atitude artística, admirada em Rembrandt por Clark é uma construção de valores estéticos da arte moderna, e não necessariamente corresponderia a preferências ou juízos arbitrários do mestre holandês.

Insistimos em examinar este debate entre o caráter "descritivo e topográfico", e o "visionário e poético", para discutir a qualidade e a intenção presente em nossa pesquisa prática. Nossas paisagens do rio Pinheiros são fruto de um olhar que busca a via da conciliação entre ambos os lados. Por que uma imagem interessada no registro, demarcando um ponto de vista preciso e localizado geograficamente, seria incompatível com a qualidade poética da paisagem? Clark insinua reiteradamente que é só o registro apaixonado da luz, que dá uma razão de ser poética às paisagens dos fatos. Mas em que medida a representação desta luz se distingue do registro descritivo da facticidade das coisas que ela ilumina?

\section{Vistas topográficas}

Características pictóricas, gosto por detalhes topográficos, horizontes em mapas passaram a ser comuns nos mapas. A presença de artistas envolvidos profissionalmente na cartografia era cada vez maior. Artistas como Pieter Pourbus trabalharam para agrimensores, fazendo mapas essencialmente topográficos. Outros pintores cartógrafos foram Pieter Saenredam, Gaspar van Wittel, Claes Jansz, e a família dos Visscher, gravadores e desenhistas de mapas e vistas topográficas. Todos fariam forte referência a Pieter Brueghel e suas vistas de portos e batalhas navais.

O ponto discutido por Alpers nessa passagem é uma oposição entre um "modo cartográfico" e o que chama de "vistas particularmente dignas de registro". Os desenhistas holandeses tendiam a dissolver estas separações, na medida em que "[...] quando fazem 


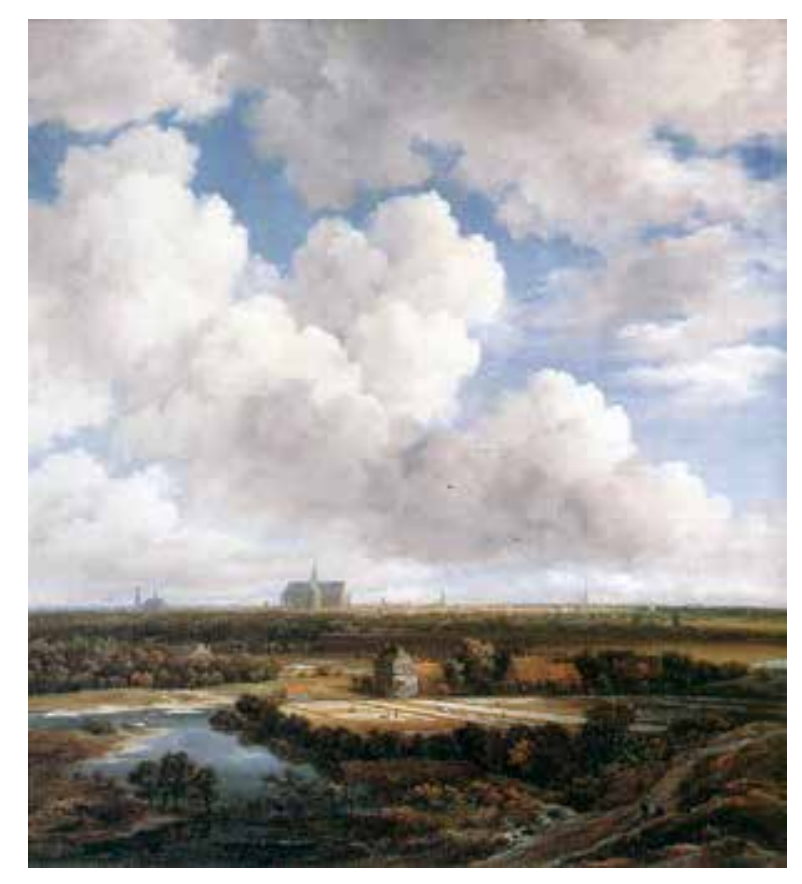

Acima [imagem 30], Jacob van Ruisdael. Vista de Haarlem. c. 1670-75, Mauritshuis, Haia

https://www.mauritshuis.nl/en/explore/the-collection/artworks/view-of-haarlem-with-bleaching-grounds-155/ anotações num desenho, indicam cuidadosamente o lugar vantajoso a partir do qual eles tomam uma vista, porque para eles o registro é inseparável da pintura. Distinguir o impulso cartográfico, como no caso de Ruisdael, não é insistir num único modo, mas marcar o começo de uma tentativa de chegar a um acordo com diferentes modos holandeses de representação paisagística.” (id., p.262) Compreende-se daí que o artista foi capaz de marcar justamente a proposição de um estilo que emprestasse suas qualidades dos diversos modos da paisagem da época. Mais uma vez fica explícito o caráter de conciliação de diferentes linguagens em um mesmo suporte, o que provavelmente contribuiu à inventividade das imagens holandesas entre os séculos XIV a XVII.

Tal caráter conciliador é caro à nossa pesquisa visual, e buscamos inserir a representação da paisagem no registro de uma anotação parcialmente “objetiva” do espaço, mas que dê vazão à sensibilidade "subjetiva”. A superação desta cisão é o que nos motiva em nossa investigação. Por que o detalhe haveria de estar subordinado à harmonia do todo? O detalhe remete ao todo na medida em que é um perfil dele, e só existe em relação à totalidade.

A opinião de Kenneth Clark (1961) sobre Ruisdael nos fornece o mesmo caráter conciliador de suas paisagens: os detalhes e pormenores aparecem em sua pintura ao mesmo tempo em que a dramaticidade e atmosfera geral da composição se afirmam, não havendo uma competição entre o detalhe e o todo. Ao falar de Ruisdael como o "maior mestre de visão natural antes de Constable”, o autor cita um sentimento patético que seria “[...] expresso, como em todos os grandes pintores de paisagem, através de efeitos de claro escuro, de tal forma que mesmo antes de uma observação cuidadosa dos seus quadros sentimos o seu significado dramático: só quando observamos mais de perto é que nos apercebemos que estão cheios de pormenores de observação. Mais uma vez a luz eleva esta observação a novos planos de realidade. Mas aqui, a luz tem um novo caráter. Já não 
é estática e saturante como em Bellini, mas sim movimento contínuo." (CLARK, 1961, pp.53-54) O movimento das nuvens seria então um motor de sombras dinâmicas, que atua como a chave para uma dramaticidade fundante na escola de pintores de paisagem que se estabelece a partir de Ruisdael até a Inglaterra de Constable, e assim por diante.

\section{Pintura, descrição, corografia}

Um ponto central à contribuição trazida por Alpers (1999) à nossa pesquisa é demonstrar particularidades etimológicas entre as noções de "descrição" e "grafia", que também revelam muito sobre o caráter cartográfico das pinturas de paisagem holandesas. A aproximação conceitual entre descritivo e gráfico é cara aos nossos propósitos, na medida em que pode indicar um modo de compreender a representação como escrita e inscrição física da paisagem em um plano de representação. A literalidade da noção de "grafia" se reforça ainda mais para nossa pesquisa pelo fato de que temos uma série de gravuras, em que a escrita da paisagem sobre um plano se dá em termos de gravação física, no sentido de incisão. Cava-se um relevo sobre uma chapa de cobre, em que se inscreve a experiência sensível da geografia.

A separação entre as "grafias" do mundo remonta ao pensamento geográfico de Ptolomeu. A Geografia de Ptolomeu, publicada e ilustrada na Renascença, constituiu-se em importante tradição. A visão de Ptolomeu já traz uma divisão entre as noções de geografia e corografia: a primeira, mais totalizante, generalizada e matemática; e a segunda mais descritiva, detalhista e particularizada. Já era muito precisa para Ptolomeu, a divisão entre o que era papel do geógrafo e o que era o papel do artista, ou "corógrafo". Mas a situação na Renascença já era muito diferente da época de Ptolomeu: as imagens pictóricas publicadas eram muitas e fomentavam a expansão do campo geográfico como disciplina. Datam do 
século XVI os primeiros grandes atlas, o de Mercator e o Civitates Orbis Terrarum de Braun e Hogenberg, que financiaram desenhistas para desenhar vistas das cidades de toda a Europa.

Ptolomeu definia o criador pictórico como Graphikos, o que remete à ideia da grafia, presente em geografia, corografia e topografia. O significado do sufixo é escrever, desenhar ou registrar. Mas os holandeses o traduziam por "pintura"(pictura, schilderij). Alpers conclui então que havia um interesse na especificidade gráfica nos registros geográficos ptolomaicos:

"Embora a palavra pintura seja introduzida, ela é inevitavelmente modificada, acompanhada ou substiuída pelo termo descrição - descriptio em latim, description em francês, beschryving em holandês. Todas essas palavras, naturalmente, dependem do latim, scribo, o equivalente do grego grapho “ (ALPERS, 1999, p.267)

A respeito da herança linguística do embaralhamento entre as noções de grafia, pintura e descrição, a autora aponta, contudo, que

“[... não era comum, na época, chamar uma pintura de descritiva, visto que descrição: ekphrasis, era o termo retórico usado para aludir a uma evocação verbal de pessoas, lugares, edifícios ou obras de arte. Como instrumento retórico, ekphrasis dependia especificamente do poder das palavras. Foi esse poder verbal que os artistas italianos da Renascença se empenharam em igualar em pintura, para rivalizar com os poetas. [ Mas quando a palavra descrição é usada por geógrafos renascentistas, ela chama a atenção, em suma, não para o poder persuasivo das palavras, mas para o sentido em que as imagens são desenhadas ou inscritas como algo escrito]. Ela chama a atenção, em suma, não para o poder persuasivo das palavras, mas para um modo de representação pictórica. A implicação gráfica do termo se distingue da implicação retórica. Voltando agora para Ptolomeu, devemos dizer que o seu termo grapho tanto poderia sugerir pintura quanto escrita." (1999, p. 267) 
Depreende-se desta passagem que, ainda que a descrição trouxesse algo de uma conotação verbal retórica, prevalecia um sentido de representação gráfica, de palavra escrita, grafada sobre alguma superfície, no discurso dos geógrafos da Renascença. Assim como a descrição era entendida como algo de caráter gráfico, a ideia de paisagem também comportava já uma ambivalência:

"A palavra landschap era empregada tanto para aludir ao que o agrimensor devia medir quanto ao que o artista devia representar." [...] "Descrição era um termo híbrido. Ainda que o único contexto pictórico em que a palavra está envolvida neste último período seja na literatura relativa aos mapas e à agrimensura, penso que ela sugere uma visão da pintura que aceita a cartografia como um de seus modos. Empregando o termo descrição, os textos geográficos aceitam a base gráfica de seu campo, ao mesmo tempo que relacionavam os seus registros com uma noção de produção de imagens." [...]

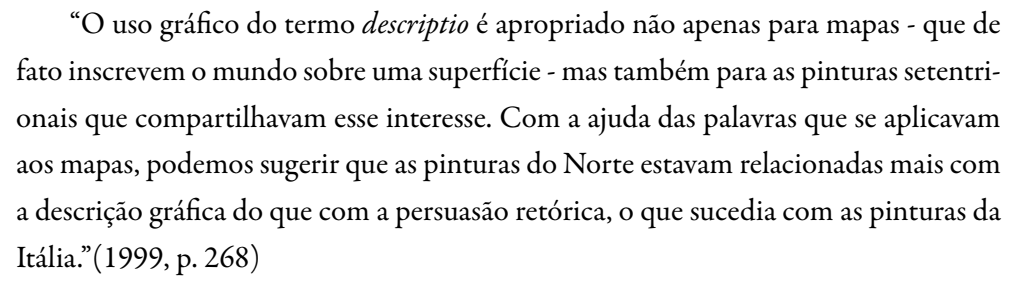

"O uso gráfico do termo descriptio é apropriado não apenas para mapas - que de fato inscrevem o mundo sobre uma superfície - mas também para as pinturas setentrionais que compartilhavam esse interesse. Com a ajuda das palavras que se aplicavam aos mapas, podemos sugerir que as pinturas do Norte estavam relacionadas mais com a descrição gráfica do que com a persuasão retórica, o que sucedia com as pinturas da Itália."(1999, p. 268)

Alpers nos informa que, para os holandeses, a compreensão do mapa como um dispositivo visual, no sentido em que a informação nele contida corresponde à visibilidade do mundo, contempla também a ideia de uma descrição, cujo código é gráfico e pictórico, da realidade. $\mathrm{O}$ mapa pertence a uma classe de artefatos da técnica que mediam uma experiência visual singular da realidade vista. 
“Os termos 'espelho', 'diante dos olhos' e 'óculos' eram aplicadas igualmente aos mapas e às pinturas na época. Norgate, por exemplo, continua sua passagem sobre a invenção da pintura paisagística com a seguinte caracterização: "a paisagem nada mais é que visões ilusórias, um meio de enganar nossos próprios olhos, com nosso próprio consentimento e ajuda por um estratagema de nossa própria imaginação." (1999, p. 299)

A autora nos traz a referência histórica ao uso da palavra "gráfico" do Oxford Dictionary: "Não é à toa que a palavra gráfico, abrangendo tanto o significado de "desenhado com lápis ou pena" quanto o de "visualmente descritivo ou natural”, é usada pela primeira vez nessa época. (id., p.299)

\section{A cartografia como hábito}

Assumindo que havia mesmo uma concepção pictórica singular na arte flamenga, é de se pensar em que medida ela interfere na relação da observação direta da realidade. Se Clark coloca tal aspecto como uma das razões para que, desde as miniaturas dos irmãos Van Eyck, já houvesse uma busca intuitiva pela luz saturante da atmosfera, Alpers observa esse fator já nas práticas da agrimensura. A paisagem dos fatos seria não tanto um afã de "realismo" quanto uma tradição cultural enraizada na relação prática com a terra.

Segundo Alpers, ocorreu na Holanda uma transformação do modo cartográfico em representação paisagística, o que seria diferente de um "nascimento do realismo" na representação. Trata-se uma "nova atitude para com a terra", partilhada por agrimensores, cartógrafos e artistas. A história refere-se a Hendrick Goltzius como o "primeiro” a realizar desenhos realistas ao ar livre, mas a autora ressalta que, profissionalmente, já se tratava de uma prática corrente, um hábito cartográfico.

Uma série de convenções da linguagem visual da tradição holandesa se afirma nas 
imagens, de modo que há diversas semelhanças formais entre pinturas e mapas da época: a relação com a perspectiva não se dá em função de um ponto de vista que situe o observador no espaço virtual da imagem. Trata-se de um outro mecanismo, o de transferir a terra avistada para o plano bidimensional, num raciocínio semelhante ao da projeção do mapa. Não há tanta ênfase em reproduzir a experiência visual, e o ponto de vista espacial do olho é relativizado:

\footnotetext{
“[...] como em toda a tradição das paisagens panorâmicas que se segue, superfície e extensão são enfatizadas às expensas do volume e da solidez. Notamos essa falta dos meios de enquadramentos usuais, familiares nas representações paisagísticas que servem para situar-nos e introduzir-nos, por assim dizer, no espaço. Olhamos a partir do que é normalmente, e um tanto falaciosamente, referido como vista geral. - frase que descreve não a posição de um observador real ou do artista, mas antes a maneira pela qual a superfície da terra foi transformada numa superfície plana, bidimensional. Ela não supõe o observador localizado." (1999, p. 276)
}

Em relação a este aspecto, para reafirmar seu ponto, a autora traz a citação de Hoogstraten: "ver o mundo a partir de outro mundo, graças ao desenho"; há aí uma noção abrangente de desenho, que remete também à ideia da descrição: da mesma forma que a cartografia não é só atividade de geógrafos, o desenho, enquanto acepção ampla, desempenha uma série de funções ligadas à vida prática cotidiana. Isto contribuía para que a arte holandesa estivesse menos impregnada de sentidos transcendentes e metafísicos, e mais ligada à experiência mundana e à empiria:

"Paisagens e cartografia estão ligadas na Holanda do século XVII pela noção do que é desenhar. Na teoria dominada pelos italianos do final do século XVI, o desenho (disegno) tinha sido exaltado até o ponto em que se tornou sinônimo de ideia (idea, em italiano) de arte, e portanto do próprio ato de imaginação. Hoogstraten, 
ao contrário, introduz o desenho como algo ligado às letras formadas na escrita, ao planejamento das manobras de guerra, à medicina, à astronomia, à história natural e à geografia. O desenho é tratado mais como uma arte de funções específicas, entre as quais estão a descrição, numa página, de diferentes fenômenos observados no mundo."(1999, p. 277)

Entre outros aspectos e códigos convencionais da linguagem cartográfica, é possível apontar que, como os mapas, as torres e os moinhos nas vistas topográficas passam a ser tratados "[...] como balizas, literalmente marcas sobre a terra - como para guiar os viajantes - , e não como evocações de coisas particulares"(id., p. 278). Outro aspecto seriam os horizontes altos, aparecendo como faixas estreitas, quase na extremidade superior das imagens, o que seria um recurso comum às vistas topográficas e alguns mapas. Esta qualidade formal específica se associa em alguma medida às nossas paisagens do rio Pinheiros, em que a faixa de céu sobre o horizonte também é estreita e restrita à faixa superior da imagem, o que as justificaria como legítimas herdeiras das vistas topográficas.

\section{Planaridade da terra e continuidade com o meio urbano}

Outro aspecto fundamental à força do impulso cartográfico holandês seria a planaridade dos Países Baixos. Certamente essa topografia contribuiu para que o território holandês fosse particularmente apropriada para a cartografia, além de ser relativamente aberta e desarborizada. Por isso mesmo, era muito comum que se subisse em torres ou pontos de vista artificialmente elevados para desenhar. As vistas a partir de torres são quase um subgênero dos desenhos holandeses. Tal aspecto contempla a componente urbana que se apresenta mesmo em vistas de paisagens rurais: há quase sempre a presença de edifícios e indícios de urbanização nas vistas topográficas holandesas, mesmo que vistos ao longe.

Nesse sentido, nos interessa reafirmar que a especificidade da linguagem de 
Ao lado [imagem 31], Rembrandt Van Rijn, $O$ campo de Goldweigher, 1651, NationalGalleryof Victoria, Melbourne.

Fonte:https://www.ngv.vic.gov.au/explore/collection/work/40165/ representação paisagística se funda sempre na materialidade do espaço, cuja morfologia se reflete, via percepção visual e espacial, em convenções formais. No caso dos holandeses, a experiência viva e cotidiana de um espaço plano engendra um "arquétipo" visual da paisagem, em que a planaridade de estreitas faixas horizontais de espaço se estende em direção à distância culminando em grandes céus descobertos. Tal forma é exemplar da maioria das gravuras de paisagem Rembrandt, entre outros.

Alpers nos traz uma amostra exemplar e interessante do modo cartográfico holandês, na gravura O campo de Goldweigher de Rembrandt, datada de 1651. "Rembrandt executa um tipo familiar de paisagem mapeada, que no entanto não toma nenhuma nota particular da propriedade. [...] Rembrandt registra a configuração da terra, suas igrejas, torres, árvores e relvas e, numa extensão muito menor, o seu produto - o uso que se faz do ar livre para estender o linho." ( 1999, p. 288-89) O contraste é feito com uma paisagem rural de Rubens, em que o assunto é mais a atividade humana do que a cartografia da terra. A caça, o trabalho, os artefatos e as casas das fazendas eram retratadas por encomenda dos proprietários de terra, que descreviam e expressavam as boas condições de seu patrimônio.

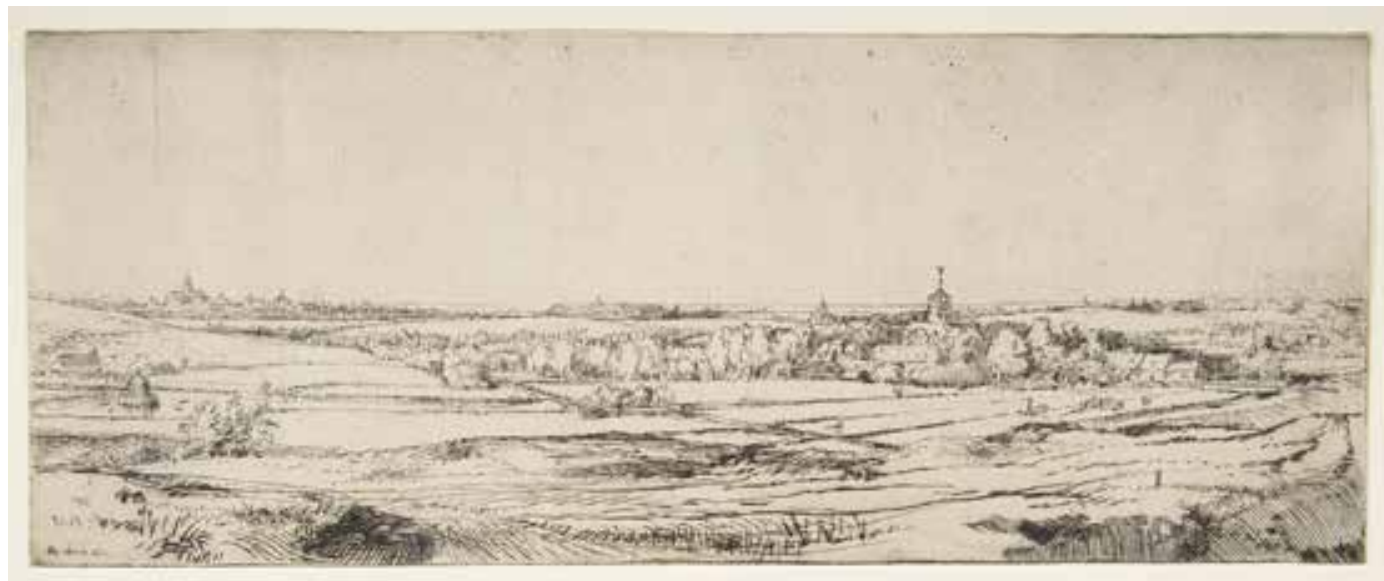


A autora atenta para um fator determinante, que transparece na gravura de Rembrandt, que é a presença da vista topográfica da cidade ao longe. A maioria das vistas cartografadas panorâmicas revelam torres de igrejas e a presença dos centros urbanos holandeses do século XVII.

"Essas pinturas, como os mapas de que elas estão próximas, oferecem-nos, isto sim, imagens de continuidade. [...] A orientação nitidamente urbana adotada tanto economicamente quanto socialmente, pela vida holandesa em terra parece inspirar essas obras. Como disse o historiador econômico Van der Woude num importante artigo, 'foram a cidade, os cidadãos e as instituições urbanas que tiveram de ajustar contas com a gente das aldeias"' (1999, p. 291-292)

No que se refere à modernidade do caráter urbano da concepção de paisagem holandesa, há, na fala de Van der Woude, uma interessante e quase irônica inversão em relação à ideia de Joachim Ritter, de que a paisagem surge como função estética de uma reconciliação entre a natureza e o mundo urbano. A imagem de Ritter é a do citadino que olha para fora de sua cidade para ver a natureza como paisagem; o que teria ocorrido na Holanda é, de certa forma, o contrário, pois é do campo que se olha para a cidade, e ela integra aquilo que se chama de paisagem. À cidade é concedido um lugar na paisagem, e há continuidade entre natureza e urbanidade, não uma cisão nostálgica.

A titulo de comparação, Kenneth Clark (1961) afirma que seria só a partir do século XVII que a escola holandesa de pintura de paisagem passa a incluir as cidades e edifícios. Tal movimento é por ele caracterizado como um "[...] estranho (e, segundo creio, inexplicável) renascimento dos princípios clássicos de composição, em oposição aos princípios maneiristas dos pintores de gêneros primitivos."(CLARK, 1961, p.54) Vermeer teria sido o principal expoente de tal renascimento, influenciando nomes como Hooch, Ter Borch, Metsu, Jan Steen, Saenredam, Berckheyde e White. 
Em relação à inclusão da cidade nas paisagens, Clark nos diz que "Os holandeses eram capazes de introduzir tantos pormenores quantos quisessem nas claras estruturas geométricas de Brunelleschi e Alberti sem nos incomodar com a sua trivialidade, assim como também são capazes de introduzir uma compreensão maior ou menor de atmosfera." (1961, p. 54) A atmosfera de que ele fala teria seu ápice de perfeição na Vista de Delft, de Vermeer.

Mais uma vez, coloca-se a questão do equilíbrio entre a trivialidade do detalhe e a totalidade atmosférica: a inclusão da cidade na paisagem, com suas construções repletas de pormenores, linhas e planos retos, tenderia a ser um vção da paisagem segundo o caráter "visionário" da ambiência que Straus e Clark defendem. Em nossa paisagem do rio Pinheiros, embora não estejamos em meio à profusão de informação do centro da cidade, há que se confrontar o elemento construído, cheio de fatos e pormenores de maior ou menor relevância, com o elemento propriamente "natural" e a luminosidade atmosférica. As paisagens das ambientações urbanas têm suas características singulares em relação às convenções da paisagem idílica e intocada. Nesse sentido, os holandeses foram precursores da paisagem moderna e contemporânea, uma vez que não tinham problemas em ver paisagens em meio à cidade, e concebiam o meio rural e o campo como integrados à urbanidade.

É lugar comum dizer que a Vista de Delft de Jan Vermeer é considerada algo sem precedentes. A única obra que se assemelha a ela seria a Vista de Zierickzee de Esias Van der Velde, pintada 40 anos antes. Para Alpers (1999), elas pertencem a um gênero comum, que remete ao Civitates Orbis Terrarum de Braun e Hogenberg. Houve outro atlas famoso à época, publicado em 1649, o Atlas Blaeu, que tinha um modo de representação mais distante do pictórico.

Há uma tradição de estampas topográficas em que a cidade é vista de perfil, muitas 


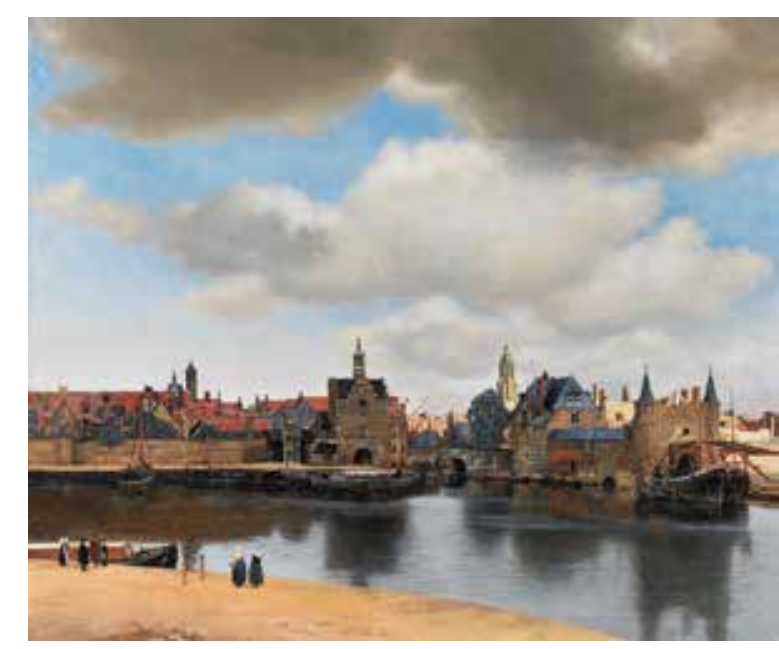

Acima [imagem 32] Jan Vermeer, Vista de Delft, 1660-61, Mauritshuis, Haia.

Fonte:https://en.wikipedia.org/wiki/View_of_ Delft vezes do outro lado de um corpo d'água, como a Vista de Nijmegen, de Hendrik Vroom, de 1615. Muitas vezes, essas vistas eram encomendadas pela própria cidade aos artistas, e a Vista de Haia de Van Goyen (1651), a Vista de Amsterdã de Rembrandt (1643) e a Vista de Delft de Vermeer se inserem nessa tradição. Mas a obra de Vermeer é de uma precisão sem igual, e parece mais tradicional, conservadora como maneira de ver sua cidade.

A análise de Kenneth Clark (1961) sobre a Vista de Delft não segue a via da tradição cartográfica que a encampa. No entanto, a perspectiva histórica que ela nos coloca toca outro aspecto teórico significativo que já aponta para o desfecho das paisagens dos fatos: a hipótese de que a técnica subverteu a relação dos pintores com a transcrição da luz, pela popularização da câmara luminosa:

"Vermeer não só possuía um sentido quase sobrenatural de tonalidade, como também a usava com uma frieza quase inumana. Não permitia que determinado ponto da cena absorvesse o seu interesse, e até procurava representar tudo com completa imparcialidade de foco. E é realmente essa a nossa primeira impressão da pintura e base de sua popularidade junto dos que normalmente não se interessam por pintura. Mas quanto mais estudamos a Vista de Delft mais a consideramos como obra de arte, mais notamos como a sua composição é cuidadosamente estudada, e mais consistentes todos os seus componentes."(CLARK, 1961, pp. 54-55)

A maestria e sutileza de Vermeer teria sido, como em outros grandes nomes da pintura, o que o tornou exceção em meio a um percurso de decadência do gênero mais "factual" das paisagens pictóricas. A paisagem como descrição topográfica da natureza, de sua luz e dos fatos dados, por si só não resistiria sem uma componente de genialidade artística:

"Pelos fins do século XVII, a pintura da luz deixou de ser um ato de amor e tornou-se um estratagema. A câmara luminosa já não era um objeto de espanto, mas acessório habitual do artista. Nem havia aquele sentido subjacente da importância da 
natureza na vida diária que deu origem àquelas afirmações da verdade das aparências da natureza.[...] A natureza, como disse Carlyle, tinha-se tornado um velho relógio que podia ser desmontado e montado de novo conforme o gosto. Não admira que a pintura de paisagem se tornasse simples trabalho de artífice, de acordo com certas fórmulas. E esse fato relacionava-se com a topografia." (1961,p. 55)

Em um desfecho em direção ao século XVIII, Clark afirma uma "impossibilidade da pintura naturalista”, e o explica a partir do exemplo de Gainsborough. O pintor em sua juventude nutria especial gosto pelas paisagens e pela observação dos fatos, mas aos poucos abandonou tais interesses em função de um estilo fundado mais em sua invenção dentro do estúdio. A opinião de Clark, baseada em uma carta a um cliente de Gainsborough em que o pintor se recusa a pintar uma encomenda de paisagens pintadas ao natural, é a de que não havia paisagens reais na Inglaterra que servissem de assunto a pinturas com qualidade equiparável à dos mestres antigos. Pode-se concluir daí que, para Gainsborough, a paisagem dos fatos havia se esgotado na medida em que se tornou mera topografia, e a história da pintura já apontava para outras direções. Tal exemplo serve de argumento à narrativa de Clark, de que a facilidade de reprodução do aspecto natural da paisagem propiciada pela protofotografia da câmara obscura acabou por tornar a paisagem dos fatos um estilo artificial e decadente.

A narrativa do historiador anuncia, com o declínio das paisagens dos fatos, uma nova etapa na história das paisagens, um olhar idealista e romântico que passará a estruturar a relação poética com as paisagens, onde não mais preponderam a exterioridade e o interesse pela descrição, mas sim uma sensibilidade lírica que dá sentido à paisagem não como fato visível, mas como expressão de afetividades e anseios mais profundos e sublimes da mente e da alma humana.

Podemos refletir sobre a crítica colocada por Clark ao excesso de detalhamento, 
à obsessão pelo factual na pintura de paisagens a exemplo, novamente, do pensamento de Shitao. O princípio geral da luz, que está ausente nas paisagens meramente topográficas, seria talvez um análogo ao que o pintor chinês chama de "Síntese do Um”. A “multiplicidade dos seres" e a apreensão do princípio sintético geral da paisagem se articulam numa dinâmica complexa. Trata-se de uma das muitas inflexões da ideia de uma "totalidade no particular", da busca por uma unidade da experiência da natureza, que, ao longo da história, se associou à paisagem, e que, de certa forma, é aquilo que a paisagem exprime e significa.

\section{"A substância da paisagem realiza-se alcançando o princípio do Universo.}

A beleza exterior da paisagem se realiza pelo domínio das técnicas do pincel e da tinta. Prendendo-se unicamente a essa beleza exterior sem levar em conta o princípio, o princípio encontra-se em perigo.

Prendendo-se unicamente ao princípio, desprezando a técnica, a técnica torna-se medíocre.

Os mestres da Antiguidade haviam compreendido bem esse perigo e essa mediocridade, e é por isso que se empenhavam em realizar a Síntese do $\mathrm{Um}^{12}$.

Se o Um não está totalmente apreendido, a multiplicidade dos seres torna-se obstáculo.

Se o Um está totalmente apreendido, a multiplicidade dos seres revela sua ordem harmoniosa.

O princípio da pintura e a técnica do pincel não são outra coisa que, de um lado, a substância interior do Universo e, de outro, a sua beleza exterior." (Shitao apud RYCKMANS, 2010. p.89)

12. Segundo nota do tradutor, o conceito do Um é presente em diversos momentos dos textos de Shitao, mas neste caso específico, "[...] ele é considerado sob o aspecto particular de síntese da aparência exterior e da substância interior, forma e conteúdo." RYCKMANS, 2010. p.91

A busca simultânea pela unidade e pelo detalhamento, o desejo de abarcar o mundo e todas as coisas sem que tal multiplicidade apague a identidade sensível da experiência, é talvez o enigma essencial da representação da paisagem. A linha tênue entre situar-se e perder-se na paisagem define um dos problemas essenciais à sua compreensão. Se foi o 
amor à visão da luz ou o amor à experiência do território o que propiciou um dos mais argutos espíritos paisagísticos, não nos cabe decidir. Mas é certo que nossa pesquisa empírica sobre a paisagem do rio se ampara sobre ambas expressões da afetividade. 


\section{CAPÍTULO 3}


3.

\section{Pirajuçara: uma imersão em um dos braços do rio}

Pinheiros

Na página seguinte [imagem 33], Pirajuçara, 2016. água tinta sobre papel de algodão, $30 \times 20 \mathrm{~cm}$,
Esta série de imagens descreve as vistas que temos ao subir o córrego Pirajuçara. Este córrego deságua no rio Pinheiros onde se inicia a série de vistas apresentadas no capítulo anterior. O que se esconde atrás daquela primeira vista da margem [imagem 16, p. 69] é justamente esta vegetação aparentemente densa que cobre a foz do córrego Pirajuçara. No caso específico desta vista, olhamos em direção ao rio Pinheiros, mas não o vemos, e tampouco vemos a água do córrego. O rio é visto em perspectiva, mas ela está obstruída pelo estrato arbóreo que protagoniza a cena.

Onde está, então, o córrego? O caráter ambíguo desta imagem parece ser explicado pela faixa horizontal que marca a porção inferior. A princípio, ela pode sugerir que vemos a margem oposta, como nas vistas das margens do rio Pinheiros. Das três faixas inferiores, a mais escura poderia representar a água, mas a representação é duvidosa, e a textura desta faixa sugere também a natureza dura, pétrea, do concreto das margens do canal. As faixas nos afastam da vegetação que se vê ao fundo, tal como um muro, parecendo conter o mato que avança, pesando sobre ele. As faixas inferiores parecem sustentar uma cena sobre um palco, e a massa arbórea, então, ocorre como apresentação, apartada para um "segundo plano", que quase se cola com o primeiro, que o invade em nossa direção.

Se o que vemos é a margem oposta, a faixa mais escura representa a água do córrego, mas a faixa mais clara acima dela parece muito regular, estreita. Seria então a faixa horizontal o muro de arrimo que sustenta a margem do córrego? Se sim, a água então não aparece na imagem.

Em um segundo momento, em relação às imagens que a sucedem, temos o córrego Pirajuçara sempre visto no sentido de seu curso, "perspectivado". Essas vistas do rio colocam-nos um outro olhar, que não é mais o das margens do rio Pinheiros. Não estamos mais vendo a margem oposta, mas, sim, as duas margens. Não estamos nadando no córrego Pirajuçara, mas pairamos sobre ele: estamos sobre algo como pontes, mas elas não são 
1. O córrego Pirajuçara nasce no município de Embu das Artes, passa por Taboão da Serra, e, em seus quase 18 quilômetros de extensão, compreende uma bacia de aproximadamente 120 outros riachos até desaguar no rio Pinheiros.

Na página seguinte [imagem 34], Pirajuçara I, óleo s/ cartão, 39x $64 \mathrm{~cm}, 2017$ pontes elevadas; é o córrego, na sua qualidade de duto, que passa sob a cidade construída.

Se o que vemos é o leito do rio correndo em perspectiva, em direção ao fundo, a faixa horizontal representa uma mureta, separando o plano da calçada da vegetação que faz fundo. O córrego, no entanto, está escondido sob o denso "matagal" que se põe diante de nós, deixando-nos entrever algo da luz do céu ao fundo, invadindo em fachos ocasionais o jogo de sombras contrastadas que se articula com a folhagem luminosa que vemos mais de perto.

Trata-se, de fato, da imagem menos "literal" que temos do córrego Pirajuçara, e ela inicia a série justamente trazendo a paisagem para uma escala reduzida, quase intimista, numa imagem de um riacho semi-oculto. Idealmente, córregos são corpos d'água estreitos, de pouco volume de água, cuja presença espacial é discreta, e na natureza seu fluxo de água se arrasta pelo relevo quase sorrateiro, sem produzir situações de divisão espacial como as dos rios. Nas cidades e no campo cultivado, mesmo sua forma canalizada reproduz algo de seu movimento silencioso e tímido, e sua forma visual se dá entre o ocultamento e a aparição. É da natureza dos córregos e dos regatos surgir, brotar aqui e ali, meandro a meandro, voltando a se esconder sob a vegetação, e é esta uma característica básica que torna a paisagem configurada ao longo dos córregos diferente daquela que configura os rios. Não é somente uma relação de escala; há uma qualidade diferente, o córrego não segrega tanto dois mundos entre suas margens quanto o rio, e suas margens, ao contrário,muitas vezes se tocam pelas copas das árvores, bloqueando parcialmente a luz do céu. Em alguns trechos, é possível perceber ambas as margens como um terreno contínuo: o rio corta a paisagem sem dividir tão marcadamente um "aqui" de um "lá".

Ocorre que nos trechos mais urbanizados do córrego Pirajuçara ${ }^{1}$, sua canalização produziu um leito relativamente alargado, e a amplidão da paisagem à sua volta chega a aproximar-se à de um ribeirão. Para além de deslocá-lo para um “subsolo", um nível abaixo 


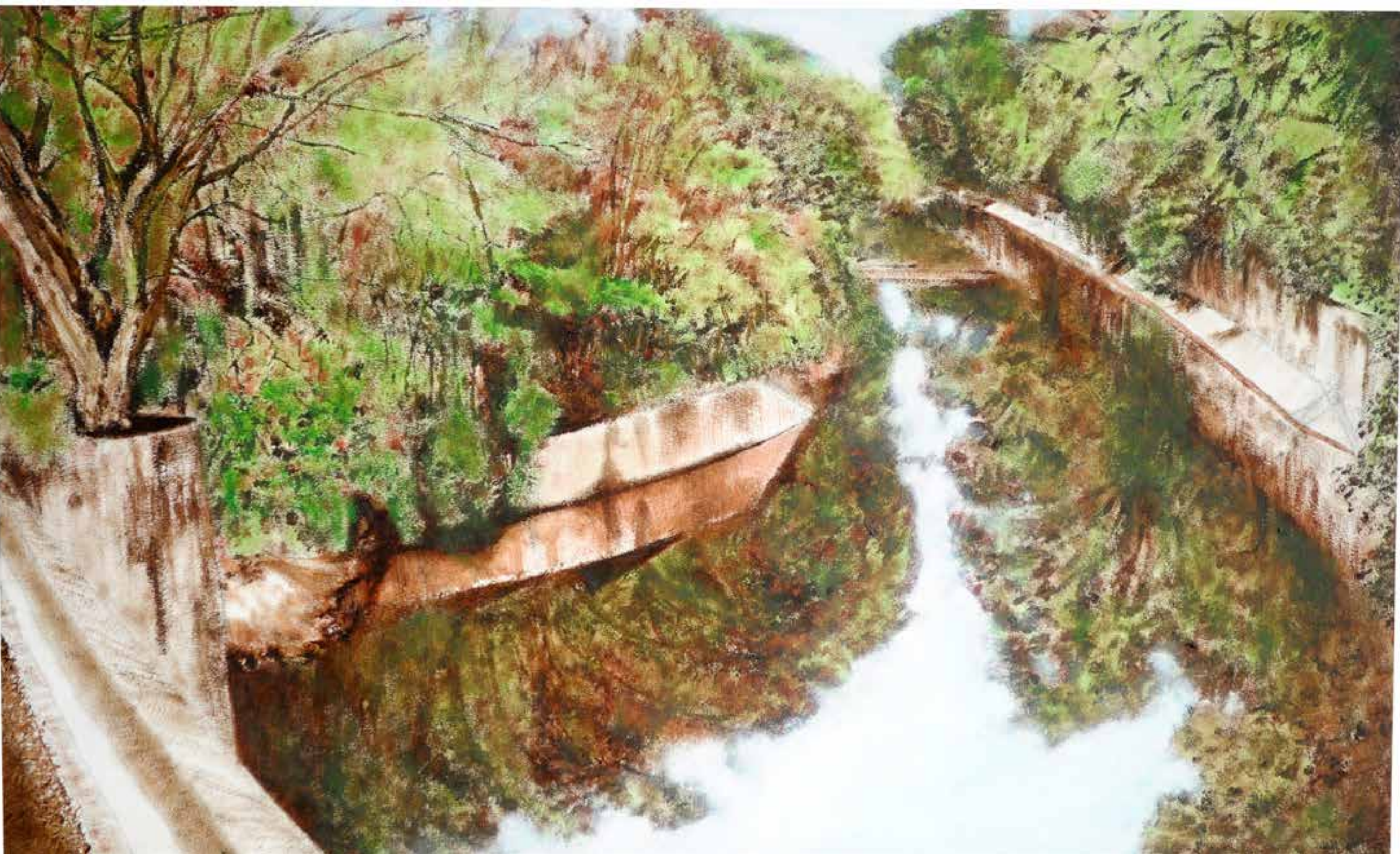


Na página seguinte [imagem 35], Paço Abandonado, 2012. Água forte e água tinta s/ papel de algodão. $29.5 \times 15 \mathrm{~cm}$. do das ruas, sua canalização nos mostra esse jogo de aparecer e esconder das águas sob a faceta rígida do planejamento da infra-estrutura. Há uma ordenação racional e um sentido prático que se sobrepõem a um projeto paisagístico no tratamento dado ao córrego. O desenho técnico característico da construção civil, que conforma o Pirajuçara, desloca nosso imaginário das paisagens para um terreno curioso: as margens que o conformam se parecem com galerias de drenagem, são de ordem tecnológica, e suas formas não têm razão de ser propriamente estética; mas há, por outro lado, uma estranha esteticidade na construção desse córrego, formas que nos remetem a algo do brutalismo, que se afigura às suas margens.

De fato, à medida que subimos o córrego, nos afastando de sua foz no rio Pinheiros, vemos que essas formas se ligam a uma mesma linguagem construtiva presente na Cidade Universitária, e o exemplo do anexo em ruínas do Paço das Artes, colado à margem direita do Córrego Pirajuçara, assim como o edifício da Academia de Polícia, à sua margem esquerda. A gravura nos mostra o interior das ruínas do anexo do Paço das Artes, que tem seu interior parcialmente alagado em seu nível mais baixo, no subsolo, por ocasião das chuvas de verão, formando um nítido espelho d'água dentro desse projeto abandonado, configurando um cenário cavernoso, grotesco, em que a luz do sol adentra pelas extremidades para iluminar, no reflexo da água, a regularidade cuidadosa das lajes do teto. A luz ilumina também a presença de uma vegetação que cresce ao lado do edifício, à semelhança da margem espelhada dos rios.

No plano da história da arte, tal imagem evoca também uma manifestação particularmente poética da ruína do brutalismo paulista. Temos uma quase irônica consumação fatal de uma intenção estética de criar arquiteturas em que a brutalidade das caixas de concreto se abre e se integra, ao nível do solo, à natureza, criando espaços abertos, em uma intenção de conferir organicidade ao racionalismo do espaço, com transições entre 


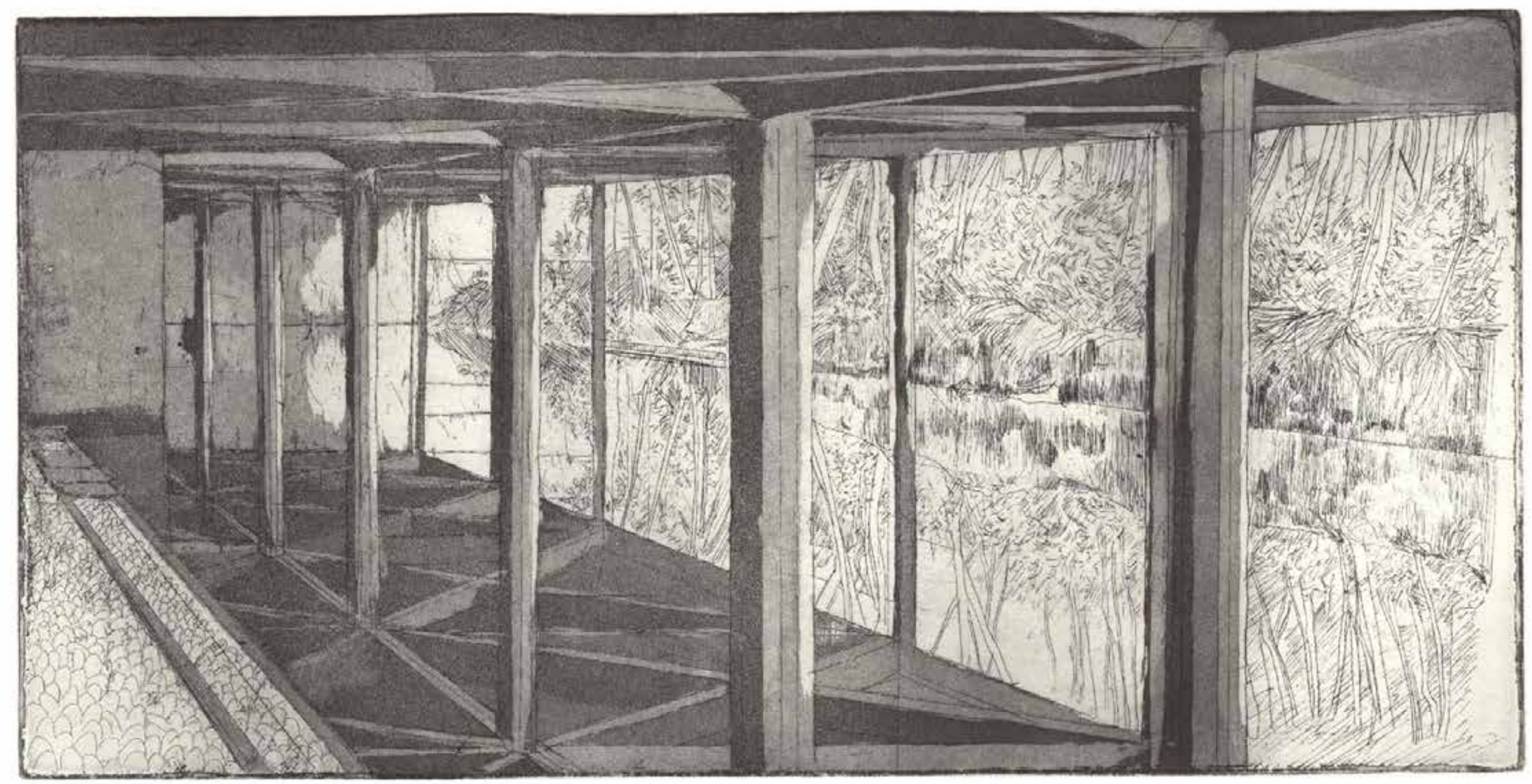


exterior e interior, que se expressa em uma série de ícones da arquitetura moderna paulista.

Há um caráter simultaneamente precário e engenhoso que dá forma a essa suposta "paisagem" do córrego Pirajuçara, que é também a paisagem das águas da Cidade Universitária, que é, por sua vez, uma breve viagem por uma braço da paisagem do rio Pinheiros. Evidentemente, essas formas não são exclusivas deste córrego, mas são as formas da construção civil da cidade de São Paulo. Há uma linguagem do concreto que permeia os empreendimentos da engenharia hidráulica e das pontes, que é a mesma que se vê nas margens dos rios Pinheiros, Tietê e Tamanduateí.

Da razão prática e utilitária de ser das margens que enformam o córrego, aflora talvez uma "linguagem visual" dos não-lugares criados pela engenharia, repleta de acidentes e incidentes que, em termos de visualidade, podem assumir um caráter acidentalmente ornamental. A superfície funcionalmente adornada dos muros de arrimo do córrego, em que blocos de concreto se extrudam, em que bocas e buracos se abrem aqui e ali. A superfície do concreto é cuidadosamente pintada de um tom terroso pela poeira, pelo limo e pela vida vegetal que adere às paredes e pelas suas próprias exsudações. Algo de um mistério, de uma curiosidade pitoresca, é visível no jogo entre a firme contenção do solo das margens e o ímpeto com que a vegetação se debruça sobre o córrego.

Não é só o fato de que as margens são artificiais e dotadas de alguma intenção paisagística que as torna singulares. Há nelas certa estranheza, que combina necessidades relacionadas ao plano urbanístico da Cidade Universitária, como a segregação lotes, cálculos de vazão, enchentes e normas de saneamento. Soma-se a isso uma improvável e tímida“vontade paisagística”de se preservar algo da vida de um córrego que já se foi, de sua organicidade de formas. Esta combinação de intenções e projetos de cidade engendra um cenário quase fantástico, em alguma medida distópico, decadente, que traz de princípio a falência assumida da função estética desta paisagem fluvial. 


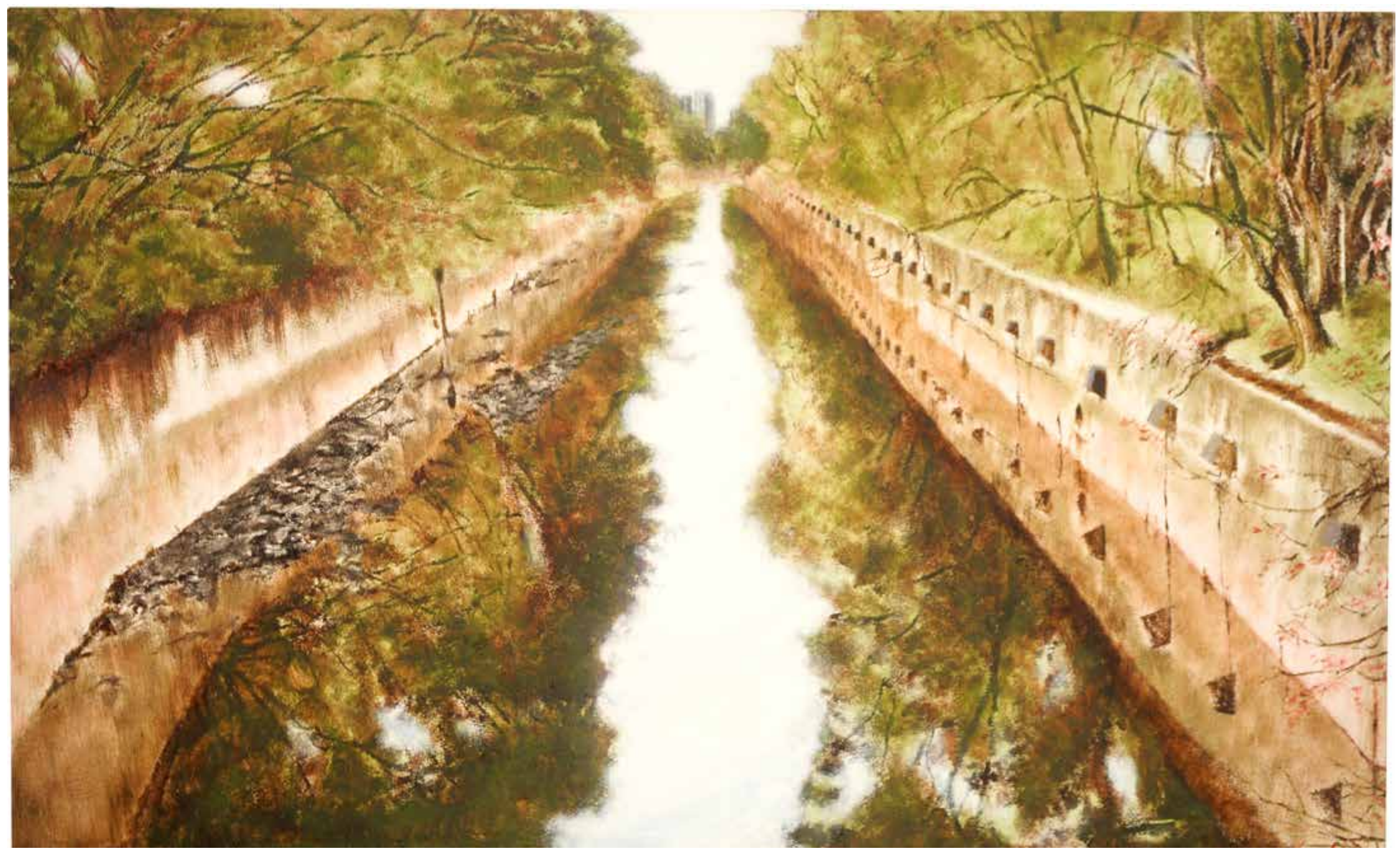


É manifesta nesta série de imagens uma conjugação entre imaginários históricos de paisagem. Em primeiro lugar, há um sutil caráter de paisagem romântica e ideal no tratamento dado à luz geral, aos contrastes entre luz e sombra nas plantas, e no tratamento das cores, que trazem uma construção de sombras por camadas de cor, mais terrosas e avermelhadas ao fundo do verde das folhas progressivamente iluminadas. Há uma dramaticidade exagerada na profundeza das sombras, mista à insolação de uma luz quente, que confere às paisagens uma atmosfera densa, abafada, como se o ar estivesse tomado pelo vapor da água do córrego. Em meio às pesadas sombras da vegetação despontam áreas iluminadas mais ou menos diretamente por um céu semi-obstruído, e um tom avermelhado se dispersa pela superfície dos fatos da paisagem, conferindo a eles uma carnação, um calor que emana das camadas subjacentes da tinta.

Em segundo lugar, transparece a sobreposição de um imaginário romântico de paisagem a uma figuração algo "futurista", partindo da estetização da cidade pósindustrial em suas manifestações decadentes, numa retórica visual que reafirma o fracasso inconfesso de intenções paisagísticas direcionadas a este córrego. Certa melancolia nostálgica transparece nestas imagens, principalmente nas pinturas, em que vemos um tratamento pictórico e uma fatura que nos remete, com o devido distanciamento histórico, às intenções visuais das paisagens anteriores à arte moderna. No entanto, os fatos e formas desta paisagem do córrego Pirajuçara, em sua singularidade, colocamnos diante de um cenário distante daquele do idílio ou da arcádia. Pelo contrário, afirma-se a paisagem no interior de uma história sem deuses e heróis, distante da universalidade primitiva.

Ainda assim, é visível uma intenção um tanto pitoresca, que persiste em olhar para este córrego com os olhos da paisagem ideal, e por mais que as formas construídas presentes às suas margens comuniquem-nos sobre o esgoto e os espaços residuais 


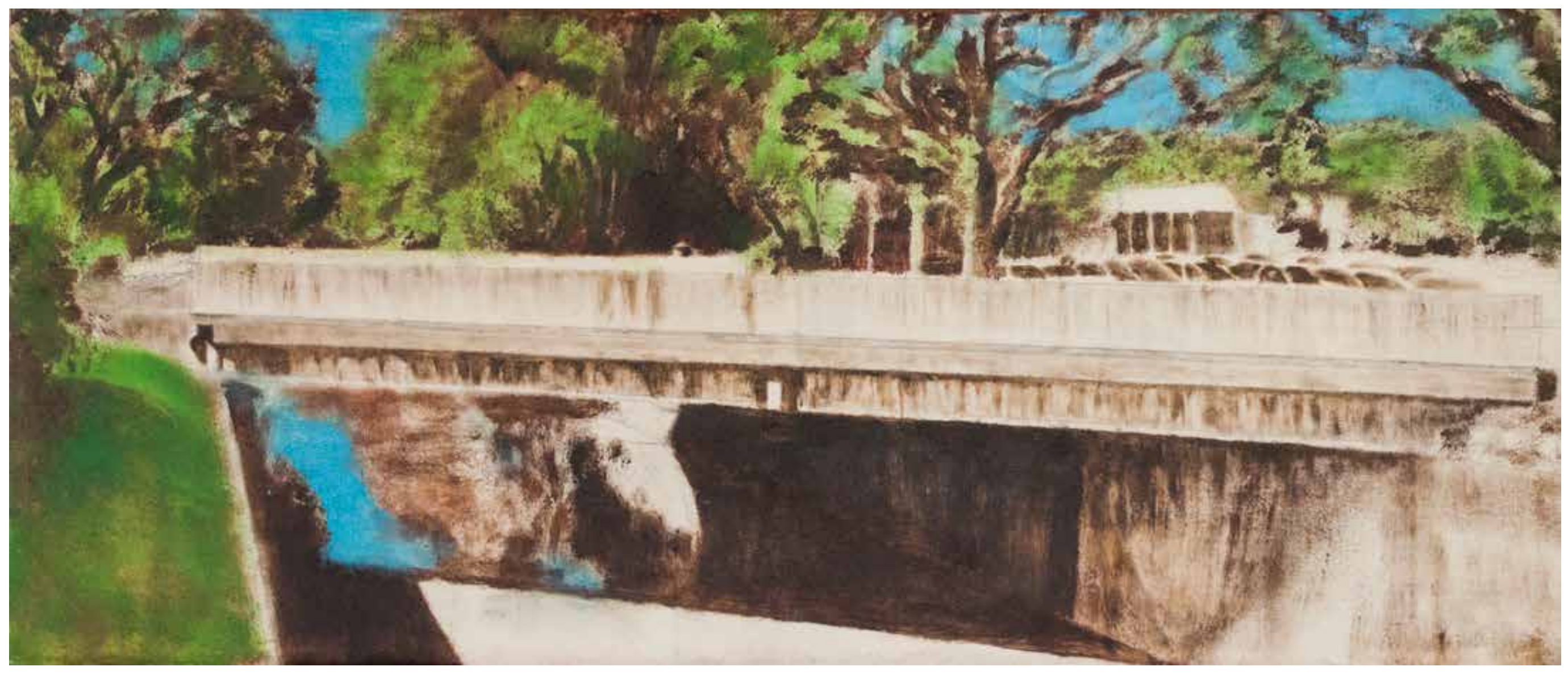


da cidade, nos é transmitido um encantamento romântico pelas cores, pela luz e pelo modo de se registrar graficamente as árvores e arbustos. Há nelas uma tranqüilidade, uma quietude, um bem-estar proporcionado por uma breve fuga da cidade, mas esta quietude é acrescida de certa dramaticidade simbólica: vemos sempre uma margem iluminada em frente a outra obscurecida, correspondendo a uma situação de luz natural, mas que, por meio da pintura, se revela idealizada, remetendo às paisagens ideais de Rembrandt, em que há um facho de luz solar em diagonal em meio a um céu de nuvens escuras.

É como se o córrego estivesse dentro de um parque que não realiza propriamente esta função (o que de fato se aplica à Cidade Universitária), pois as margens do rio não são habitadas por gente alguma, não são feitas para se estar, são muros, espaços públicos segregados, aos quais o acesso não é permitido. E, ainda assim, persiste a componente paisagística, em grande medida proporcionada pela vegetação que reveste a estrutura canalizada das margens do córrego, na maneira como a luz do céu se entrevê através das copas das árvores, e pela própria presença das águas e seu reflexo.

A componente de idealidade nas paisagens pintadas parece ser, antes de tudo, um atributo historicamente difícil de ser contornado. A presença de paisagens ideais no imaginário visual das paisagens está em nós cristalizada de tal maneira, que o mínimo índice de graciosidade e harmonia reconhecido como próprio do "belo natural" já nos leva a conceber representações de aspecto idílico. Mesmo que a cultura pictórica das paisagens tenha se desenvolvido de diversas formas ao longo da história, o referencial das paisagens ideais e românticas tende a povoar com maior preponderância as tentativas de se representar a paisagem, gerando a profusão de paisagens kitsch do artesanato e da ilustração, e, em alguma medida, mesmo na arte 


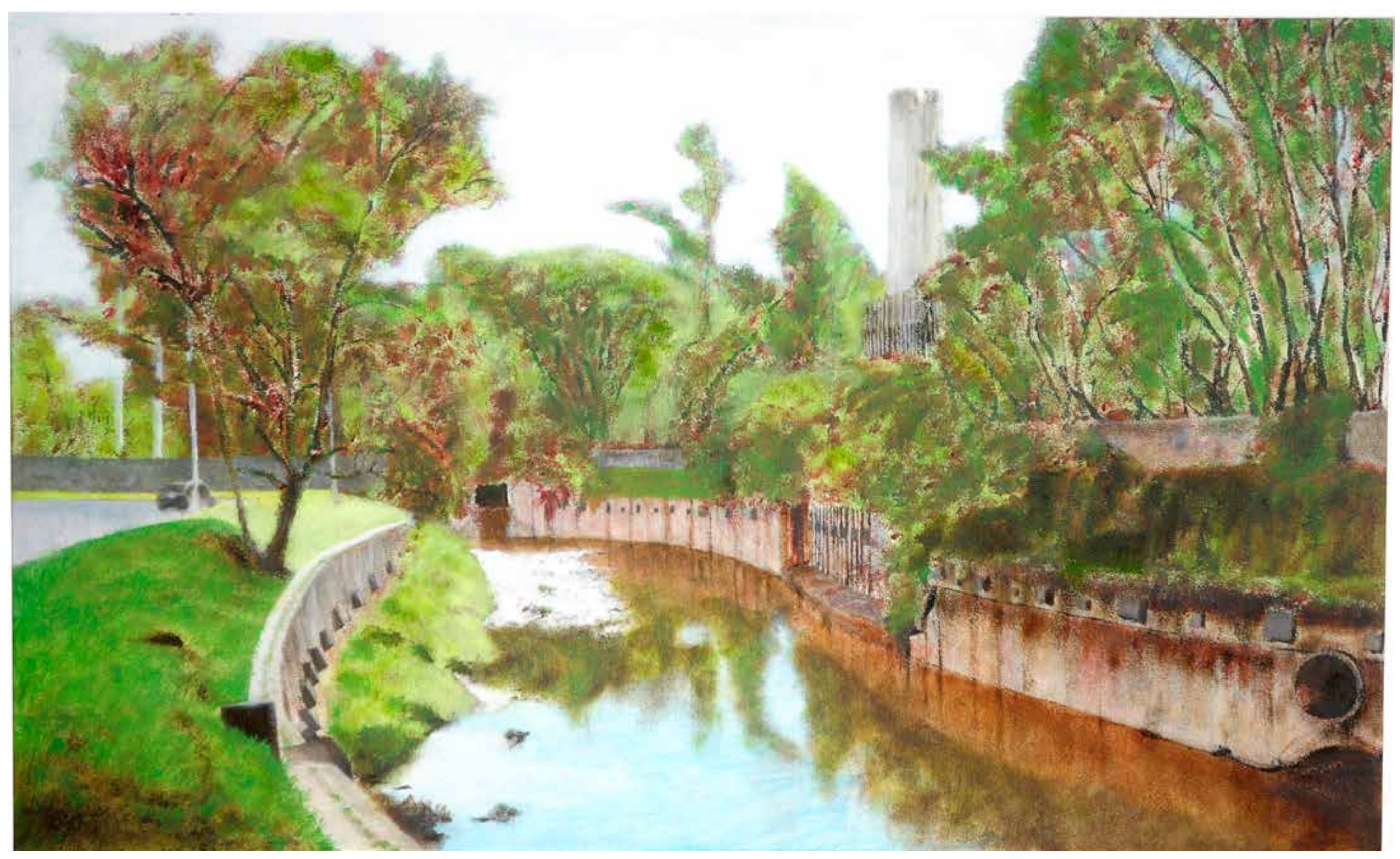


contemporânea institucionalizada. Em geral, se tentamos escapar desse imaginário paisagístico pictórico, acabamos reféns do imaginário visual fotográfico das paisagens do cinema, da televisão, da publicidade e do turismo.

Afora os aspectos até aqui expostos sobre a idealidade que se vê nas paisagens do córrego Pirajuçara, nos interessa examinar, a partir das definições de Kenneth Clark (1961), em que medida há nelas qualidades de composição e construção de imagem típicas das paisagens ideais, que nos aproximem um pouco mais da razão pela qual estas obras têm algo da linguagem visual de uma vertente específica da história da paisagem na arte.

\section{1.}

\section{$O$ ideal nas paisagens}

Na página seguinte [imagem 39], Pirajuçara $V$, óleo s/ madeira, $18 \times 31 \mathrm{~cm}, 2017$
Entre as categorias enunciadas por Kenneth Clark (1961) para distinguir diferentes atitudes artísticas diante da paisagem pictórica, se situa aquela que o autor define como "paisagem ideal". Ela não se distingue da "paisagem dos fatos" por um critério cronológico ou geográfico, mas sim como um conjunto de características presentes em exemplos particulares de pinturas, que surgiu na Renascença e que teria perdurado até o início do século XIX. Por vezes, um mesmo pintor, segundo o autor, teria produzido tanto "paisagens dos fatos", quanto "paisagens ideais" e "paisagens fantásticas" em sua carreira; assim como é possível reconhecer em uma mesma paisagem traços de uma ou mais categorias cunhadas pelo historiador.

Já de início, Clark nos diz que, nas paisagens ideais, a presença de uma narratividade lírica, no sentido do tema ou assunto, não é suficiente para definirmos uma paisagem ideal. Daí podemos depreender que há uma linguagem das paisagens ideais cujos parâmet- 


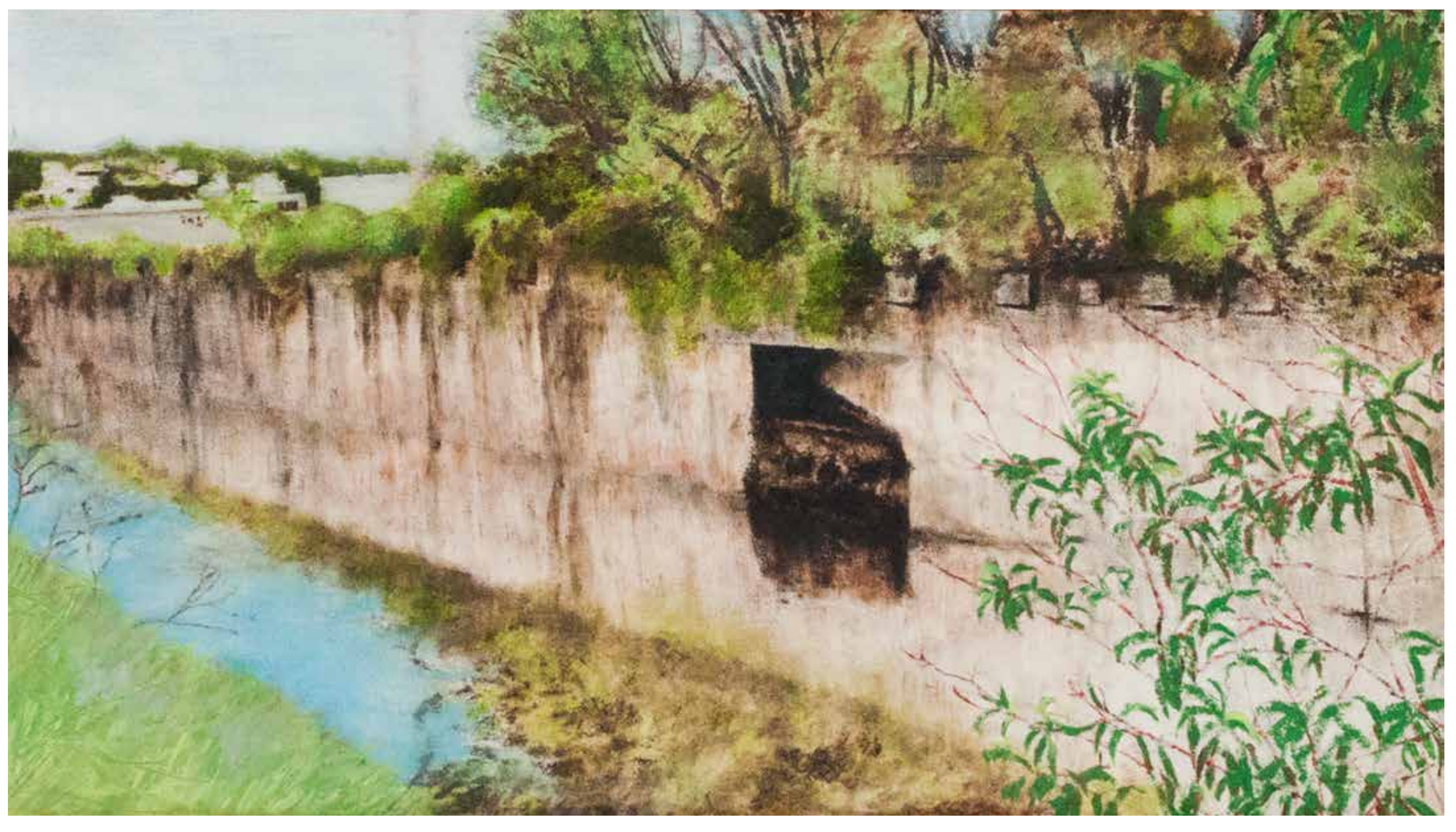


2. A atribuição de tal qualidade às paisagens de uma determinada tradição poderia ser explicitada talvez pela herança de uma concepção hegeliana da idealidade, expressa, grosso modo, em termos da relação entre a forma e o conteúdo na arte. Nos interessa aqui observar qual seria o sentido de tal adjetivo "ideal" para este olhar em relação à paisagem; busca-se a rearticulação das aparências da natureza de modo que expressem uma ordem do divino, de modo que a exterioridade das formas mostre a interioridade do conceito. Assim como cada elemento sensível do quadro converge para um princípio estruturador, em Hegel, a “Ideia”, enquanto conteúdo da arte, é a exposição sensível de um "Ideal Absoluto", que reconcilia o conceito com a objetividade. O ideal se particulariza nas formas e se singulariza na arte. Não é objetivo de nossa pesquisa provar a relação histórica do conceito de "paisagem ideal" com a estética de Hegel, mas sem dúvida há mais nesse conceito do que a simples referência a um imaginário idílico da beleza natural: a idealidade se expressa como pensamento visual. Cf. HEGEL, G. W. F., Cursos de Estética-vol. I- São Paulo : Edusp, 2001. pp. 165-187 ros são formais: uma sintaxe que preza pelas composições e arranjos harmoniosos do continente pictórico. Há nas paisagens ideais um sentido de equilíbrio no movimento visual que, como na harmonia musical, engendra cadeias de tensões e resoluções cuja dinâmica tende à elegância da forma e ao equilíbrio, o que não pressupõe qualquer simplicidade. Trata-se de um princípio harmônico da composição para o qual as forças endógenas do arranjo contribuem integralmente, não bastando a alusão a este ou outro tema da sensibilidade lírica classicista para que a idealidade seja atingida ${ }^{2}$.

Em relação às paisagens dos fatos, é como se nas paisagens ideais ocorresse uma depuração em que se rearticula a forma e a função de cada fato visual com a função de atingir uma determinada finalidade afetiva e poética. $\mathrm{O}$ caráter descritivo, o interesse pelos fatos paisagísticos por meio da luz não se impõe, como aos mestres flamengos; o tratamento específico dado a cada detalhe se subordina a uma luminosidade e a um colorido que contribui para o arranjo geral da cena, que expressa, ela toda, uma animação coordenada.

"Antes que a pintura de paisagem pudesse constituir um fim em si, tinha de se adaptar ao conceito ideal a que obedeciam todos os artistas e críticos de arte nos trezentos anos que se seguiram à Renascença. O prazer pela imitação que satisfazia $\mathrm{Al}$ berti e Bellini, não era suficiente para Lomazzo e Carracci.Tanto no conteúdo como na concepção, a paisagem deve aspirar àquelas altas espécies de pintura que ilustram um tema religioso, histórico ou poético. $\mathrm{E}$ isto não se pode conseguir introduzindo simplesmente um pequeno grupo de figuras representando a Fuga para o Egito ou a História de Eurídice, mas pelo espírito e caráter de toda a cena. (CLARK, 1961,p. 78)

Haveria um "primitivismo suave" correspondente às paisagens ideais, oposto a um “primitivismo duro", relativo à concepção das paisagens fantásticas. A evocação do mundo 

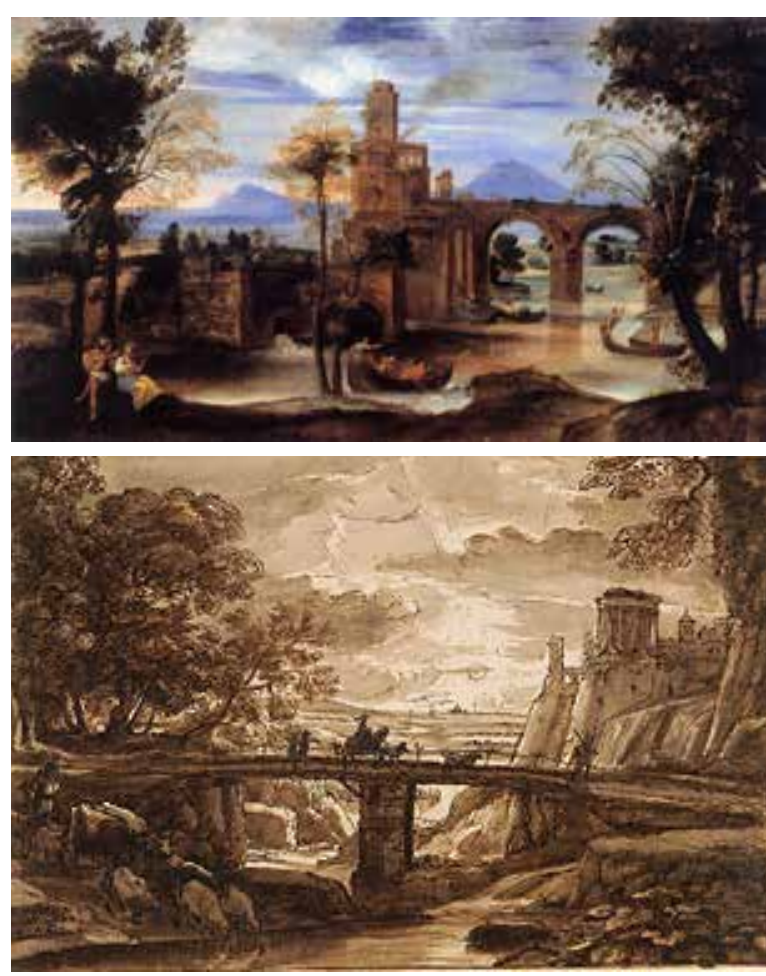

No topo [imagem 40], Annibale Carracci, Roman River Landscape with Castle and Bridge, 1595-1600, Oil on canvas, 73 x $143 \mathrm{~cm}$, Staatliche Museen, Berlim.

Fonte:https://www.wga.hu/html_m/c/carracci/annibale/2/romanriv.html

Na sequência [imagem 41], Claude Lorrain, Landscape with a Rider and an Idealized View of Tivoli, 1642. Pen and brown ink with dark brown wash on white paper, 25,4 $\mathrm{x}$ 19,7. The British Museum, London.

Fonte:http://oldmasterdrawings.net/2007/09/ claude-lorrain-landscape-drawings-british-museum-clark-art-institute/\#.XDOenSMrK_I antigo, nas paisagens ideais, cria cenários que tornam o paraíso palpável, provável e dotado de semelhanças verossímeis à beleza natural terrena, ainda que se afigurem neles seres fantásticos e personagens míticas.

O lirismo presente nas paisagens ideais de Giorgione (imagem 6, p. 61) e em algumas de Bellini é visível nos efeitos graciosos da luminosidade que tece os contornos das folhas das árvores. O arcadismo influenciou essa elegância clássica da qual a pintura italiana é o maior expoente. A riqueza do colorido veneziano, nas palavras de Sannazzaro, nos serve para descrever esta característica da paisagem ideal: "Era a hora em que o crepúsculo bordava em todo o ocidente centenas de variedades de nuvens, algumas violetas, outras azuis escuras, e outras carmezins; outras entre o amarelo e o verde e algumas tão rubras de fogo que pareciam a imagem do mais fino ouro polido". (1961, p. 81)

Para Clark, o verdadeiro herdeiro da poética ideal de Giorgione foi Claude Lorrain. Segundo o relato de seu amigo Sandrart, sabe-se que Claude pintava quase exclusivamente de observação, e a aparente simplicidade de suas obras traz uma profunda preparação por meio de esboços do natural que eram incluídos em suas composições. Na passagem que segue, Clark reconhece muito daquilo que compreende como qualidades modernas da pintura de paisagem, ou seja, impressionistas, no olhar de Claude: “ Por vezes são estudos cuidadosos do pormenor, por vezes são inteiramente impressionistas no sentido da luz. Por vezes têm uma delicadeza de expressão própria da pintura chinesa." (1961, p.88)

Tais desenhos de estudo de Claude teriam servido de modelo para os aquarelistas ingleses como Alexander Cozens e Thomas Gainsborough. A respeito das pinturas de Claude, Clark observa que há uma harmonia de absoluta perfeição, e toda a sua habilidade na percepção das aparências se subordinava à qualidade poética que almejava transmitir. Tal competência, em parte, se fundaria em esquemas de composição complexos, em que recursos específicos colaboravam para a transição de planos em profundidade com 
desenvoltura, ritmo e bom gosto.

“[...] Claude quase sempre se sujeitava a um sistema base de composição. Este consistia num grande bastidor num dos lados cuja sombra se estendia pelo primeiro plano, um plano médio com um grande volume central, geralmente um grupo de árvores, e finalmente dois planos, um atrás do outro, sendo o segundo uma daquelas distancias luminosas pelas quais sempre foi famoso, e que, como já vimos, pintava diretamente da natureza. É necessária muita arte para conduzir a vista de um plano para o outro, e Claude empregava pontes, rios, gado atravessando uma corrente e outros artifícios semelhantes;[...] Este método de compor em sucessivos planos que por vezes e à primeira vista parecem pouco mais do que silhuetas dá à forma das massas escuras um papel de uma importância pouco vulgar. [...] Apesar da sua extrema formalidade, não há nada em Claude que seja pura fórmula." (1961, pp. 89-90)

O trecho é particularmente interessante para compreendermos o que se poderia chamar de um "léxico" de formas da paisagem ideal claudiana. Em sua fórmula, há o que Clark chama de um "bastidor" que, de certa forma emoldura a paisagem dentro do próprio quadro, sem que se crie divisões de planos abruptas. A intenção de conduzir o olhar do espectador de um plano a outro é expressa, como afirma o autor, na presença de "artifícios", corpos que transpõem a paisagem plano a plano em direção à profundidade, como rios e pontes. A referência não poderia ser mais conveniente à análise de nossas pinturas do córrego Pirajuçara, uma vez que nelas também vemos composições com "bastidores", em que há uma "contenção" da paisagem, protagonizada por elementos verticais e horizontais em primeiro plano, à esquerda e à direita da imagem, sejam árvores ou elementos arquitetônicos.

As "massas escuras" e as "silhuetas" nos planos que se dispõem nas paisagens ideais são representativas de um modo de ver que, sem intenção prévia, se colocou nas paisagens do córrego Pirajuçara por conta das próprias formas particulares dos espaços construídos 

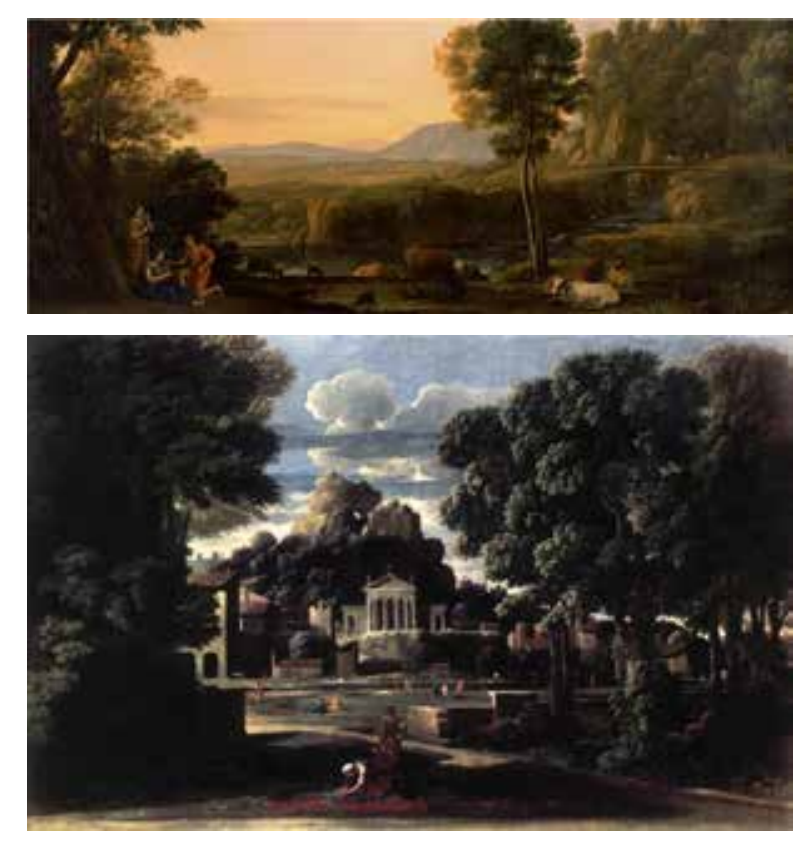

No topo [imagem 42], Claude Gelléé(Lorrain), Paisagem Pastoral, 1645. óleo s/tela $101.5 \times 134 \mathrm{~cm}$. The Barber Institute of fine Arts, Birmingham.

Fonte:http://barber.org.uk/claude-gellee-called-claudelorrain-about-16045-1682/

Na sequência [imagem 43], Nicolas Poussin, Landscape with the Gathering of the Ashes of Phocion by his Widow, 1648, óleo s/ tela. 116 x $176 \mathrm{~cm}$. Walker Art Gallery, Liverpool.

Fonte:https://pt.wikipedia.org/wiki/Ficheiro:Nicolas_Poussin_-_Landscape_with_the_Gathering_of_the Ashes_of_Phocion_by_his_Widow_-_WGA18325.jpg que o acompanham, assim como por escolhas relativas ao desenho e ao enquadramento para representar uma determinada percepção visual destes espaços e do rio.

O par oposto e complementar histórico do "[...] gentil e articulado Claude era o severo e cartesiano Poussin." O teor intelectual e simbólico de cada elemento em suas composições é atestado pela sua biografia amplamente detalhada, e, ao contrário de Claude, Poussin só passou a pintar "paisagens puras” em sua maturidade, e, como nos diz Clark, “[...] é caso para nos admirarmos que, tendo as opiniões que tinha sobre o caráter inerentemente moral da pintura tivesse tratado deste tema. Mas apesar das suas teorias, Poussin tinha grande gosto pela natureza, e podemos também supor que ambicionava conseguir uma conquista nova para o intelecto dando forma lógica até mesmo à desordem do cenário natural." (1961, p.91)

Esta última passagem de Clark nos reconduz, então, para um ponto importante, na medida em que toca o desenvolvimento da linguagem da paisagem em função da tentativa de ordenação do fenômeno visual, que estaria expressa em Poussin tanto quanto em pintores modernos como Cézanne e Seurat. Se, como nos mostrou Clark, havia nas pinturas do aparentemente "ingênuo" Claude, um sofisticado conhecimento empírico sobre o funcionamento da linguagem visual que permitiu ao pintor aplicar e experimentar variações de esquemas composicionais com grande desenvoltura e controle, também Poussin trabalhou em operações análogas, mas com uma mentalidade ainda mais formalista e maior rigor geométrico. O êxito desses artistas não se resume, é claro, somente ao rigor e disciplina de seu estudo da geometria, das técnicas de composição e aplicação da perspectiva, mas em alguma medida podemos observar que o ordenamento pelo desenho é indissociável das qualidades propriamente pictóricas e poéticas de suas obras.

A paisagem, como fenômeno visível, informa aos olhos de pintores como Claude ou Poussin um conjunto de relações visuais que podem se configurar em uma espacialidade 
3. "Poussin percebeu pois que a base da pintura da paisagem está no equilíbrio harmonioso dos elementos horizontais e verticais do desenho. Reconheceu que o espaçamento destas horizontais e verticais e as suas relações rítmicas umas com as outras podiam ter um efeito equivalente ao rítmico travée e outros processos harmônicos da arquitetura; e de fato dispôs essas horizontais e verticais de acordo com a assim chamada seção de ouro. A dificuldade principal de impor este esquema geométrico às linhas da natureza é, evidentemente, a ausência de verticais. A paisagem é essencialmente horizontal e as verticais que existem nem sempre formam ângulos retos com o chão. Para resolver esta dificuldade, Poussin, nas suas composições mais esquemáticas, gostava de introduzir a arquitetura, o que também contribuía para o seu objetivo secundário de dar um aspecto antigo ao assunto. Os grupos de edifícios são de grande importância pois dão um módulo, ou chave, ao esquema de proporções em que o desenho é construído, e por vezes, por meio de blocos de alvenaria de um templo arruinado, conseguia comunicar geometria pura a toda a composição. Para o desenho de Poussin era essencial que as verticais e horizontais se encontrassem em ângulos retos; de fato, se há uma linha que se afasta ligeiramente da vertical podemos ter a certeza de encontrar outra que se afasta ligeiramente da horizontal formando ângulo reto com a primeira."(1961, p. 92) percebida. Na tentativa de formalização desse arranjo do mundo visto, já está implícita uma discriminação de medidas sem metro, comparações de grandezas cujo critério é puramente sensível. Assim como o jogo de relações entre as formas vistas independe de uma geometria sistematizada, trata-se de uma outra geometria que, em um segundo momento, pode ou não ser mediada por um conhecimento teórico formal, como o uso da seção áurea, da perspectiva geométrica, de uma grade, ou simplesmente uma escala qualquer.

É interessante considerar que, para Claude e Poussin, os conhecimentos da perspectiva não são de forma alguma o recurso que garantirá uma boa pintura. A ilusão da espacialidade nas paisagens não se constrói pelo uso da perspectiva geométrica, ela é somente um recurso auxiliar; podemos observar que as paisagens ideais, tão cuidadosamente desenhadas, realizam a espacialidade ilusória com a disposição de faixas horizontais de matéria pictórica num embate com elementos de verticalidade. O que está "em diagonal" serve como parâmetro para cumprir a função de deslocar-nos de um plano a outro, de atravessar as faixas, ou de ligar o espaço mais distante ao mais próximo. Essas diagonais são discretas, normalmente singulares no conjunto, e dificilmente há diversas diagonais concorrendo em diversos sentidos na paisagem; quando isso ocorre, é comum que uma ou duas diagonais principais se imponham sobre a composição. Muitas vezes, as diagonais não são aparentes, mas se pronunciam por entre as relações com outros elementos visuais, sejam eles pontos, linhas, faixas horizontais ou elementos verticais.

Por si só, as estruturas compositivas de Poussin são uma aula de desenho³. Seu manejo da horizontalidade é rigorosamente controlado, e as dinâmicas de movimento de forças e pesos se orientam segundo a seção áurea; a arquitetura exerce o papel de recurso visual por excelência na organização da paisagem, equilibrando com linhas retas aquelas que não formam ângulos retos com a horizontalidade do chão. Sua compreensão de que a arquitetura funciona como módulo de ordenação do movimento visual, assim como a da 
Ao lado [imagem 44], Nicolas Poussin, Landscape with a calm, 1650-51. óleo s/ tela, $97 \times 131 \mathrm{~cm}$. J. Paul Getty Museum, Los Angeles

Fonte: https://www.pubhist.com/w5181

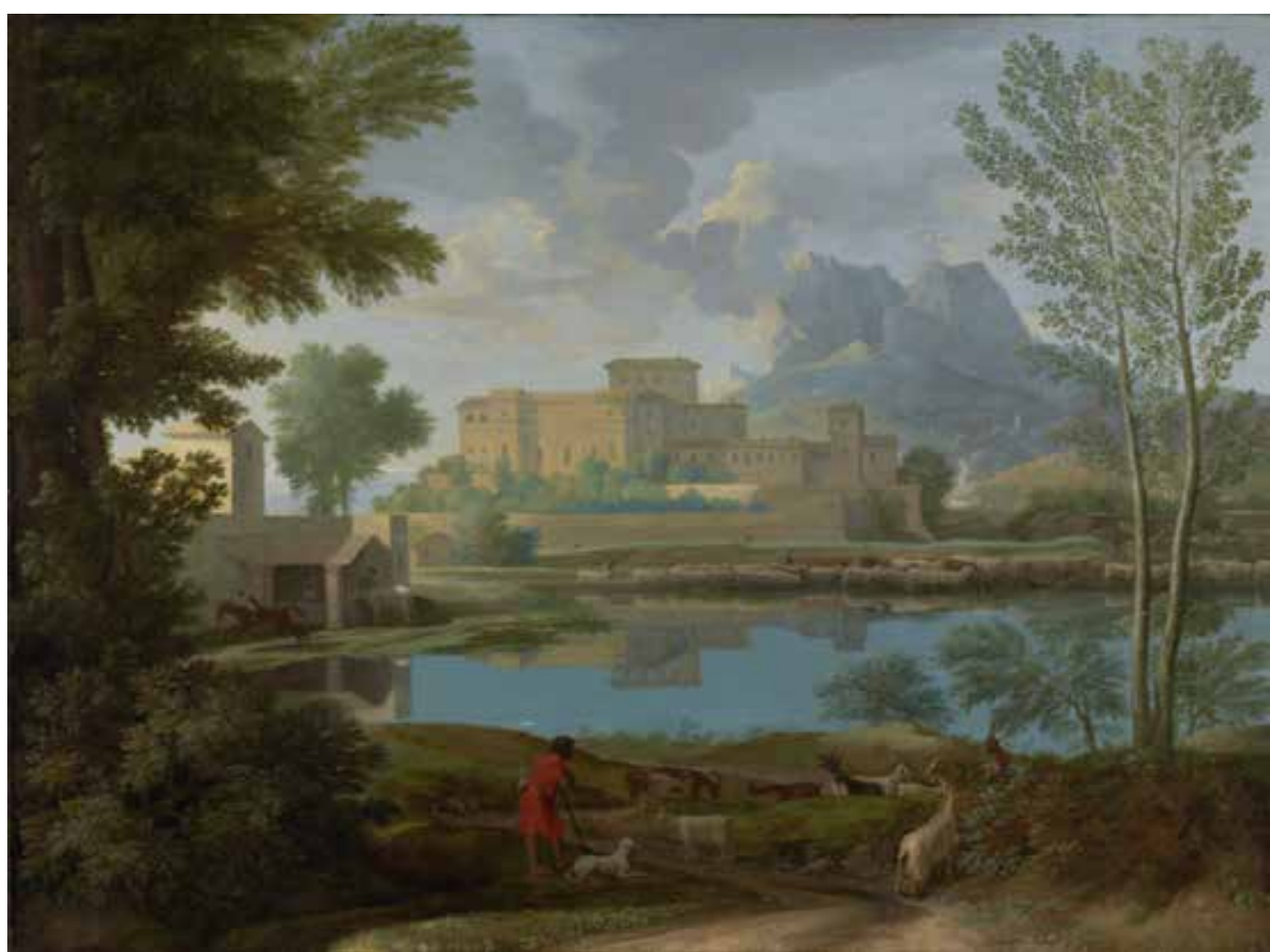

função que o ângulo cumpre à harmonia compositiva em meio à organicidade das formas naturais, contribui especialmente à nossa pesquisa sobre a linguagem visual da paisagem nas ambientações urbanas. Em Poussin, o emprego da arquitetura ainda contribuía à idealidade, sugerindo um aspecto antigo às suas paisagens.

"Esta insistência no ângulo reto só é possível quando o eixo principal da composição é paralelo ao plano do quadro, o que contribui para a frontalidade da paisagem de Poussin, uma condição tão diferente da nossa visão vulgar como das massas volumétricas em serpentina do maneirismo. Mas visto que a penetração do 
espaço é a essência da paisagem, Poussin tinha de arranjar um meio de conduzir o nosso olhar até a distância. Não há dúvida que a maneira mais apropriada ao seu espírito matemático era o ponto central de perspectiva, mas ele viu que isto era um meio demasiado rígido e artificial para ser mais do que uma solução ocasional ${ }^{4}$. Introduziu então dentro da estrutura de horizontais um esquema subsidiário de diagonais que, suave e ritmicamente, conduziam o olhar até o fundo." (1961, p. 92)

4. Na paisagem pura parece tê-lo usado apenas uma vez, na assim chamada Paisagem com Estrada Romana, de que a melhor réplica está em Dulwich, mas usou-a frequentemente nos fundos dos quadros de figuras $\mathrm{p}$. ex., O Rapto das Sabinas. ( N. do A.)
O autor nos aponta para a sensação de "frontalidade" das composições de Poussin, característica que parece ser comum a grande parte das imagens de paisagem. Parece haver uma correlação inversa entre a frontalidade, “[...] condição tão diferente da nossa visão vulgar [...]", e a “[...]penetração do espaço [que] é a essência da paisagem[...]”. Quanto mais nivelados e ortogonais nossos olhos se postam em relação à paisagem, menos podemos criar a sensação, percepção ou ilusão de espacialidade ou profundidade. Mas aos grandes pintores, como Poussin, tal dificuldade não se impõe como impeditiva, e é mais um desafio de desenho a ser graciosamente enfrentado.

A frontalidade parece ser a característica predominante nas nossas paisagens do rio Pinheiros, o que não vale tanto para as do córrego Pirajuçara. Em parte, elas resultam de um olhar em ângulo, com ênfase na perspectiva ditada pelo rio; mas parte delas colocam a frontalidade no plano de fundo, ao qual somos levados por uma perspectiva de ponto central, de modo semelhante ao que ocorre no plano de fundo da imagem acima. Há um desejo de ordenação clássica nas paisagens do Pirajuçara, por mais que a frontalidade absoluta não seja seu aspecto mais evidente.

Segundo acredita Clark, o precursor do caráter construtivo e geométrico que a paisagem de Poussin apresenta teria sido Bellini. Exemplos dessa atitude ordenadora estão em quadros como a Alegoria Sagrada. Essa ascendência artística pode ser muito significativa, pois nos informa sobre a presença, em pleno renascimento italiano, de um 


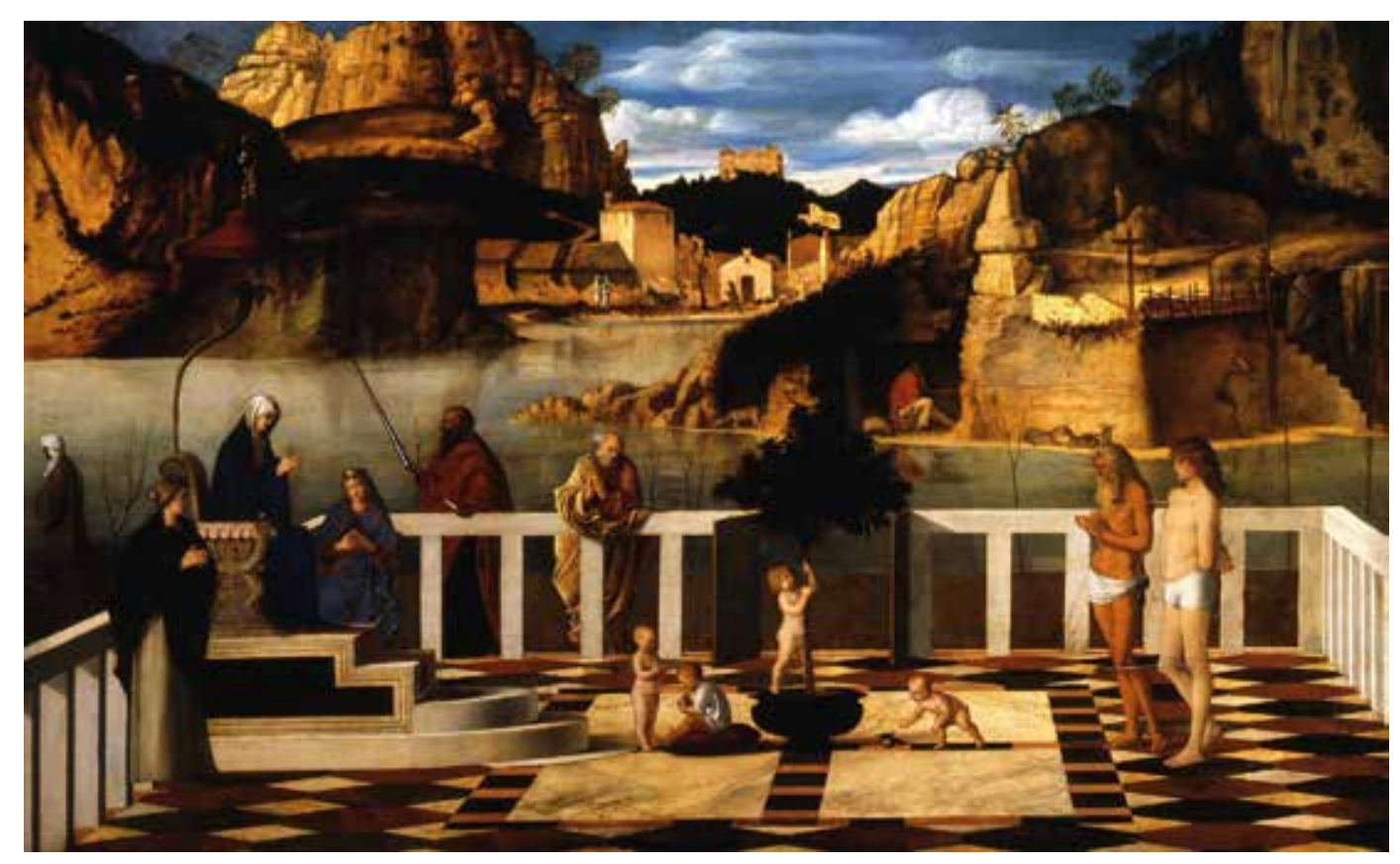

Ao lado [imagem 45], Giovanni Bellini, Alegoria Sagrada, 1490. Óleo e têmpera s/ madeira. 73x 119 cm. Galeria degli Uffizi, Florença.

Fonte:http://virusdaarte.net/giovanni-bellini-alegoria-sagrada/ sentido empírico de perspectiva, de uma linguagem paisagística geométrica e, no entanto, insubordinada à perspectiva albertiana. Quando essa perspectiva se coloca, em Bellini, ela ocupa somente um primeiro plano, e a paisagem ocorre atrás do espaço perspectivado. Trata-se de um argumento válido para sustentar aquilo que, desde o primeiro capítulo, vem sendo discutido: que o desenvolvimento, e mesmo o nascimento, da paisagem da Renascença ocorre também a despeito da invenção da perspectiva geométrica, e é muitas vezes a perspectiva que se adéqua a outras sintaxes formais preexistentes, cuja origem se dá no embate com a experiência e a tradição da representação de paisagens.

O desenvolvimento dos fundamentos empíricos da representação da paisagem até o século XVII de Poussin, Claude Lorrain, Rembrandt e outros mestres se aprofundou 
e internalizou de tal maneira, que tanto as melhores paisagens ideais quanto as dos fatos nada têm de uma estranheza perspectivada, de uma rigidez cartesiana. São, pelo contrário, espacialidades mais ou menos verossímeis, umas mais ordenadas que outras, todas plenas de naturalidade e fluidez, sem que se pareçam com uma reprodução do real; elas nada têm de "fotográfico". Como nos mostra Clark, o amadurecimento dessas faculdades de imaginação do espaço paisagístico foi tal que, ao final de sua carreira, Poussin havia relaxado sua pintura extremamente geométrica para seguir princípios compositivos mais livres, mas ainda calcados na sua imaginação geometrizada da natureza. Em uma citação de Hazzlit lemos que:

"[Poussin]Aplica a natureza aos seus próprios fins, pinta suas imagens de acordo com os modelos de seu próprio pensamento... e uma vez estabelecida a primeira concepção todo o resto parece brotar e ser assimilado a ela, pelo processo infalível da imaginação estudiosa" [...] sabia dar ao cenário das suas fábulas heróicas aquele aspecto incomparável da natureza original, plena, sólida, grande, luxuriante, repleta de vida e de poder”. (1961., p. 94)

Para Clark, seria “[...] esta compreensão sensual tanto da forma orgânica como da abstrata que tornam as últimas paisagens de Poussin tão perfeitamente agradáveis." (1961, p. 94) O autor põe a hipótese de que a influência de Poussin na história da pintura teria sido positiva relativamente à de outros mestres como Michelangelo, Rembrandt ou Ingres, uma vez que Poussin não esgotou seu estilo, não se tornou clássico de uma forma destrutiva, produzindo meros imitadores. "A influência de Poussin foi boa porque combinava de uma maneira perfeita o ideal com o real. O seu escrupuloso sentido de composição era alimentado pela observação; as suas visões mais exaltadas permanecem concretas." (1961, p. 96)

Cabe nos determos na reflexão presente nesta última passagem de Clark com 
atenção à oposição complementar entre o ideal e o real, a forma abstrata e a orgânica nas paisagens de Poussin: a qualidade de suas paisagens seria portanto fruto de uma conciliação entre duas abordagens opostas do imaginário paisagístico: se a paisagem do fatos era demasiado "realista" e, por isso, pouco poética, a paisagem ideal era exageradamente "idealizada", e ambos os pólos desta dualidade não seriam suficientemente representativos da experiência estética demandada pelo público e pela crítica.

Reafirma-se, na análise de Clark, que os meios-termos entre as dicotomias com relação à paisagem se colocam nos mais diversos níveis como a solução plausível para saciar o desejo estético pelas paisagens. A vontade de paisagem carrega um misto de intenções, que muitas vezes não resiste ao exercício do discurso e da racionalização; tampouco a sensibilidade pura e o lirismo poético sustentam todas as paisagens. É por esse motivo que a mentalidade holandesa do século XVII, segundo lemos em Svetlana Alpers (1999), permitia a convivência entre a ciência do espaço e a arte da paisagem, uma vez que a categoria da descrição do mundo não supunha uma cisão intransponível entre ciência e arte. Este foi um terreno fértil às paisagens, uma vez que ainda hoje elas ocupam em nossa cultura formas e funções difíceis de se definir conceitualmente.

A tentativa de se conceber a paisagem como dotada de uma ordenação plausível, movida pela busca de uma linguagem "gramatical" própria do fenômeno visual na natureza teria grande importância a partir do impressionismo e se desdobraria na arte moderna abstrata, mas o que Clark nos indica é que o fundamento desta busca intelectual da pintura de paisagens já se encontrava havia séculos em desenvolvimento, até que viessem as vanguardas artísticas. Entre os que se apropriaram das lições de composição de Poussin estão Bourdon, Gaspard, Millet, Corot e Pissarro “[...]muito antes de Cézanne ter feito um regresso mais espetacular aos seus princípios.” (1961, p.96)

Assim sendo, observa-se um indício de que a tentativa de se reconstituir visual- 
mente uma ordem paralela à experiência perceptiva, uma "abstração" da paisagem, pode ser uma característica inerente à ideia visual referida a ela. Em nosso próximo capítulo, tal discussão será retomada.

Em relação a esta genealogia poussiniana de que fala o autor, é interessante notar que, de certa forma, ela se restringiu à pintura francesa, que não por acaso foi o berço do impressionismo e da pintura moderna. Se a Inglaterra se notabilizou por criar uma escola de pintura de paisagem romântica e acadêmica de alto nível, esta escola não esteve em consonância com as aspirações das vanguardas artísticas do século XIX, estas sob a hegemonia da arte francesa e do norte da Europa. Conjectura-se se haveria uma relação entre o academicismo da paisagem britânica e uma não-aceitação do princípio que combina a sensibilidade e a intelecção diante da natureza vista, tão elogiado por Clark na obra de Poussin. Para Clark, a arte britânica carrega o legado propriamente lírico e arcádico das paisagens ideais:

5. É interessante traçar um paralelo da leitura de Clark sobre as lições de Claude com os princípios orientais da pintura de paisagem proferidos por Shitao, especialmente em relação à "segunda lição": há nela presente a ideia da subordinação geral a um princípio ordenador mais "abstrato", a um estado de espírito. Seria este estado de espírito algo, em alguma medida, análogo à apreensão do "Um" de que fala Shitao? Seria este princípio algo de ordem atmosférica da Stimmung, algo que se possa sobrepor ao arranjo geral dos fatos da pintura, ou seu sentido é inerente à organização geral da composição da paisagem, de modo que tal subordinação esteja prevista já no fundamento e na organização esquemática da paisagem?
"A ideia de que uma apreciação da natureza se pode combinar com o desejo pela ordem intelectual nunca foi aceite em Inglaterra, e Claude teria sido mais adequado ao gosto inglês com sua natureza gentil, [...] nos seus olhares melancólicos para uma civilização passada e na sua convicção de que a natureza podia ser moldada para deleite do homem como o parque de um nobre, que agradava especialmente aos amadores ingleses do século XVIII." (1961, p. 96)

Um exemplo de influência na pintura inglesa de paisagens seria o pintor Richard Wilson, que teria compreendido perfeitamente "[...] as duas lições principais de Claude: que o centro de uma paisagem é uma área de luz e que tudo se deve subordinar a um único estado de espírito.”s (1961, p. 96) A respeito desta afirmação de Clark podemos destacar que a iluminação característica das paisagens ideais tem seu ponto de expansão situado ao centro da imagem. 
Ao lado [imagem 46], Richard Wilson, Vista do Tamisa, s/ data. óleo s/ tela $61 \times 76 \mathrm{~cm}$. Tate, UK. Fonte: https://www.tate.org.uk/art/artworks/wilson-a-view-of-the-thames-n01889

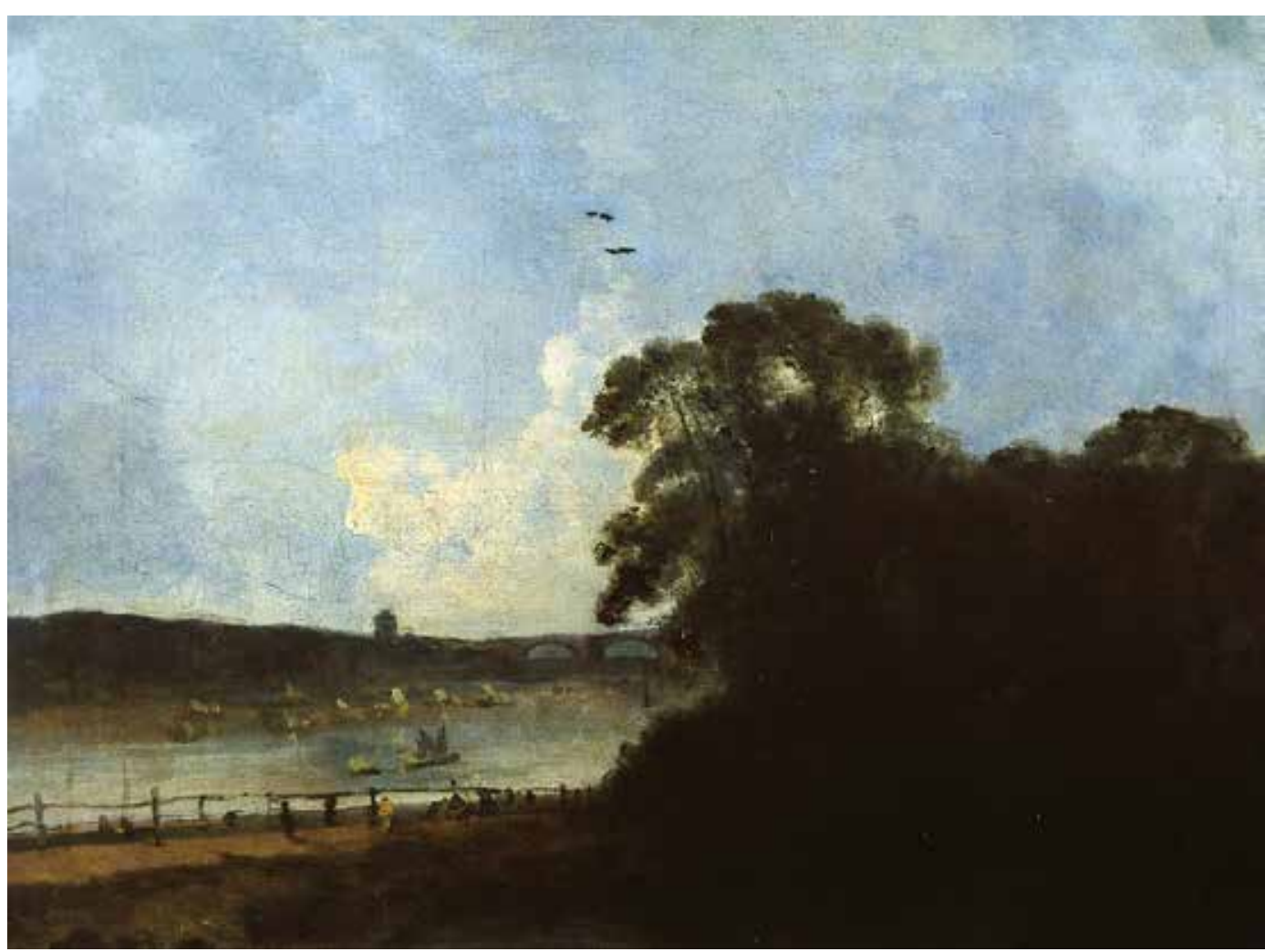

É curioso notar que, nas paisagens ideais dos exemplos mostrados, tanto quanto nas paisagens do córrego Pirajuçara, a região mais iluminada, normalmente o céu, também está mais próxima ao centro da imagem, entre duas áreas mais escuras. Como nos bastidores de Claude, a luz é vista por entre as massas de árvores, "emoldurada” por uma densa silhueta de folhas, vegetação e construção. Diferentemente das paisagens do rio Pinheiros, nelas não temos propriamente uma luz que incide "de cima” sobre as coisas, iluminando-as uniformemente. 


\subsection{Realismo, naturalismo e a} unidade da paisagem

Ao lado [imagem 47], John Constable. Flatford Mill from a Lock on the Stour, 1811, óleo s/tela $24.8 \times 29.8 \mathrm{~cm}$

Fonte: https://www.wikiart.org/en/john-constable/ flatford-mill-from-a-lock-on-the-stour-1811

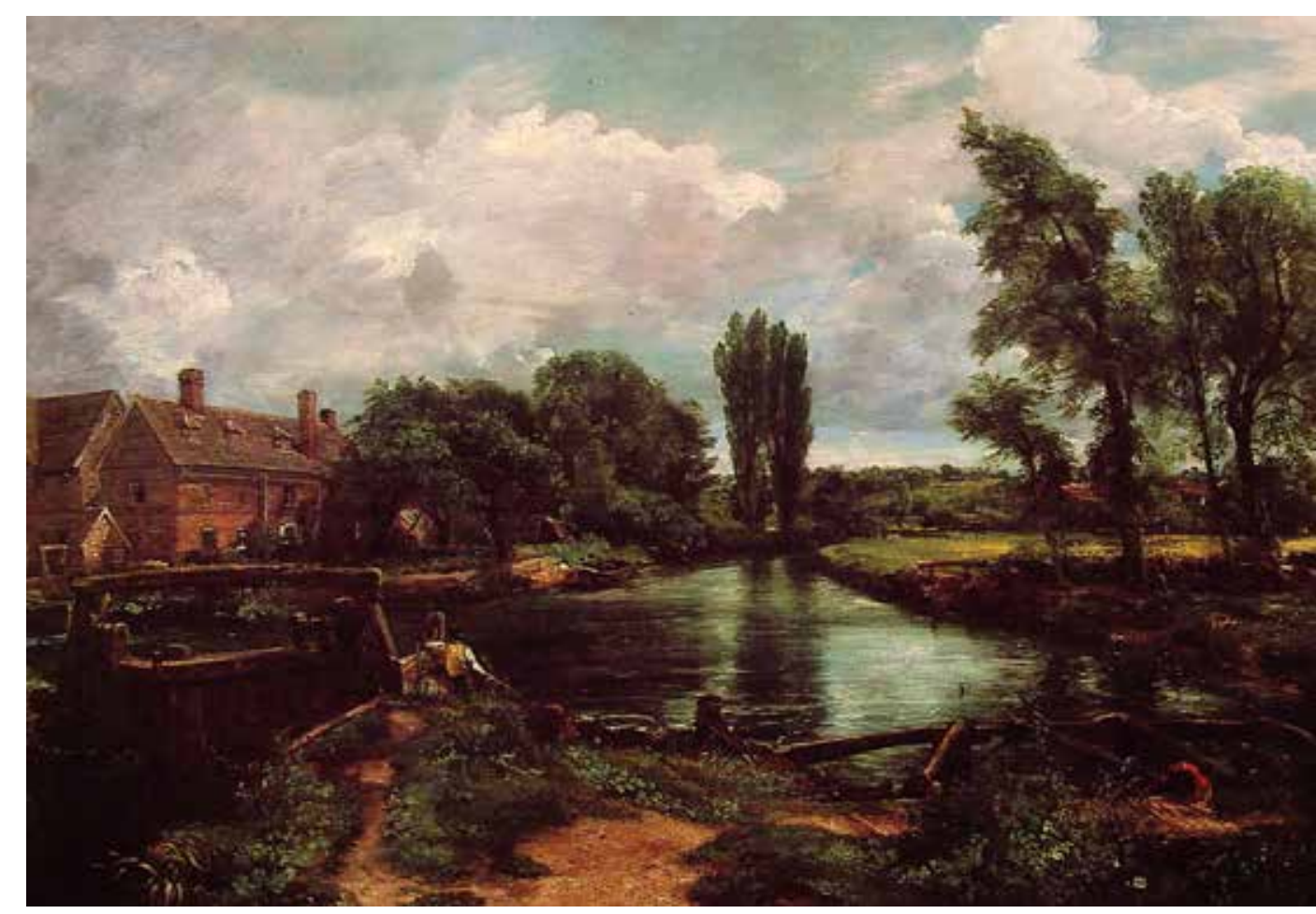

A comparação da série de vistas do córrego Pirajuçara com as características das paisagens ideais foi capaz de nos fornecer noções sobre as estruturas de composição e iluminação que se estabeleceram na pintura de paisagem. É óbvio que não se pode comparar o conteúdo de tais imagens do córrego ao conteúdo de pinturas de Claude Lorrain e Nicolas Poussin, mas podemos observar nelas características de modelos que historicamente se consolidaram, tendo grande influência na história das paisagens. Uma vez que as paisagens do córrego Pirajuçara têm uma intenção pictórica realista ou naturalista, em que se confia na visão da realidade em primeiro lugar para conceber a imagem, é frutífero 
observarmos os precursores desta tradição da pintura que viria a desencadear as paisagens modernas do impressionismo e do expressionismo.

Nas "paisagens ideais" dos séculos XVII e XVIII, se fundaram os alicerces da linguagem de pintores naturalistas tidos como românticos, como John Constable, grande expoente da paisagem pré-impressionista. Em sua série de pinturas sobre as margens do rio Stour, podemos entrever semelhanças com as pinturas do córrego Pirajuçara. Vemos nelas a mesma estrutura compositiva elementar, porém menos rigorosa e geométrica: o bastidor escuros de Poussin, em primeiro plano, combinado a uma mesma proporção de céus no terço superior da imagem, em que há centralidade da luz. Mas em Constable, como nas pinturas do Pirajuçara, não há aquela luminosidade mágica, repleta de cores, do paraíso terrestre e do primitivismo arcádico, assim como o rigor e a ordem da composição não têm a rigidez das paisagens de Poussin.

É visível que as pinturas de Constable são, como as da tradição de Claude, construídas em veladuras e camadas de cor, nas quais que a profundidade ainda se dá pela construção tonal de volumes em cores marrom-avermelhadas. No entanto, há uma maior liberdade e expressividade da pincelada, e os detalhes e pormenores como as folhas das árvores são cuidadosamente executados, mas com uma entidade menos individualizada e decorativa do que nas "paisagens ideais". Há uma humildade realista, em que a simplicidade da vida rural protagoniza cenários e temas carregados de uma dramaticidade que se acentua no colorido das sombras, e que nos faz vislumbrar uma pintura já eminentemente moderna, apesar de ainda estar presa à tradição.

Os céus contêm uma dramaticidade um tanto barroca e ocupam uma porção maior do continente pictórico do que pudemos ver nas "paisagens ideais". O tratamento pictórico dado aos detalhes como as folhas das árvores é ainda carregado de um sentido de padrão decorativo, como se cada folha expressasse sua identidade individual. Mas, em relação às paisagens de Claude 
e Poussin, temos composições menos previsíveis, perspectivas menos rigorosamente construídas e uma maior dramaticidade nas sombras. Tudo isso executado com alto grau de realismo, tanto no sentido da ilusão e da forma quanto do conteúdo da imagem. As vistas do rio Stour de Constable parecem uma pintura que há muito deixou de produzir cenários idílicos, mas que abertamente presta contas à tradição da paisagem ideal. Uma atmosfera densa de sombras pesa sobre a delicadeza pitoresca da pintura da vegetação e dos demais elementos, e é visível que a predileção de Constable, diante da tradição das paisagens, concentrou-se mais nos pintores do Norte como Rembrandt e Rubens, do que na pintura italiana.

Na reprodução seguinte [imagem 47], podemos ver o estudo realizado por Constable para a pintura da página anterior [imagem 46]. É interessante notar como a velocidade da pincelada e a agressividade da fatura com que o estudo foi feito preconizam uma pintura moderna, pois já é em alguma medida expressionista. A pintura final, feita em ateliê, traz muito da dramaticidade que o estudo inicial possui, mas o jogo de luz e sombras foi domado, seus contrastes atenuados e os volumes, profundidades e sombras construídos de maneira gradual, suavizada.

O início do século XIX marca a grande ascensão da paisagem enquanto gênero de pintura popularmente aceito e respaldado pela crítica. O "belo natural" na pintura de paisagem já havia se estabelecido no gosto popular como independente do conteúdo narrativo da obra. Uma grande quantidade de bons pintores se dedicaram ao gênero, em virtude de sua popularidade, de modo que podemos falar que o gosto do leigo pelas paisagens tendeu à indiferenciação, forçando aproximações entre o que Clark considera os verdadeiros artistas e os artistas medíocres.

Entre os mais importantes para a crítica contemporânea ao autor, estão John Constable e William Turner, no início do século XIX, preconizando aspectos pictóricos da arte das vanguardas como o impressionismo e o expressionismo. 
Ao lado [imagem 48], John Constable, Estudo para Flatford Mill from a Lock on the Stour ,1811. Óleo s/ tela 25x $30 \mathrm{~cm}$. Victoria and Albert Museum, Londres.

Fonte:https://pt.wahooart.com/A55A04/W.nsf/O/ BRUE-7YYNFQ

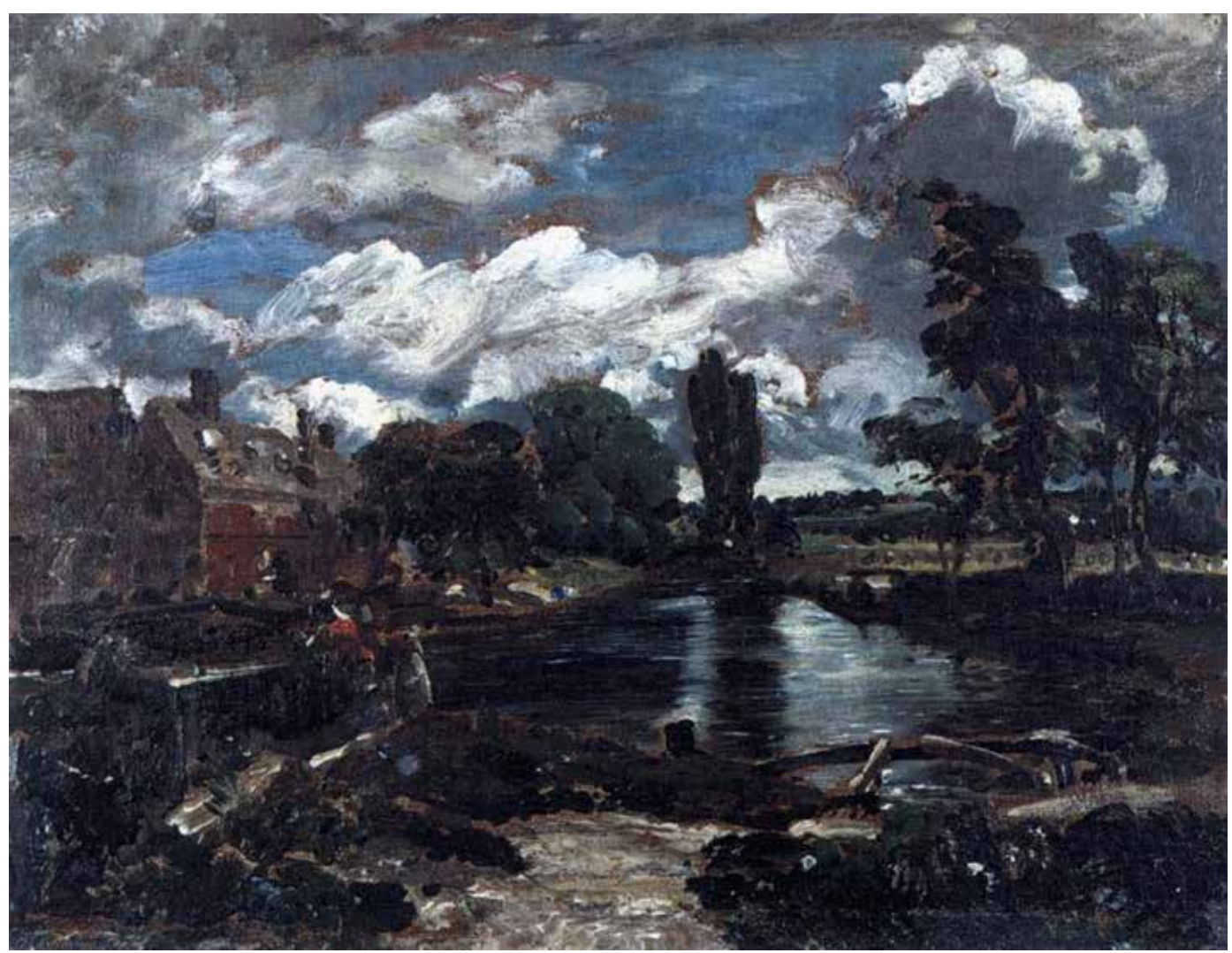

Constable seria o mais representativo daquilo que Clark nomeia o "naturalismo incondicional", uma espécie de realismo fundado em um pensamento ainda, de certa forma, romântico e idealista em relação à paisagem. Constable afirmava que " [...] ]sua arte poderia ser encontrada debaixo de cada sebe” (1961, p. 101), na crença de que não há no mundo paisagens mais ou menos especiais, e sim de que é a visão do artista que torna qualquer paisagem uma verdadeira pintura. A busca realista pela observação do natural seria o bastante para produzir grandes paisagens, não importando tanto a nobreza e o 


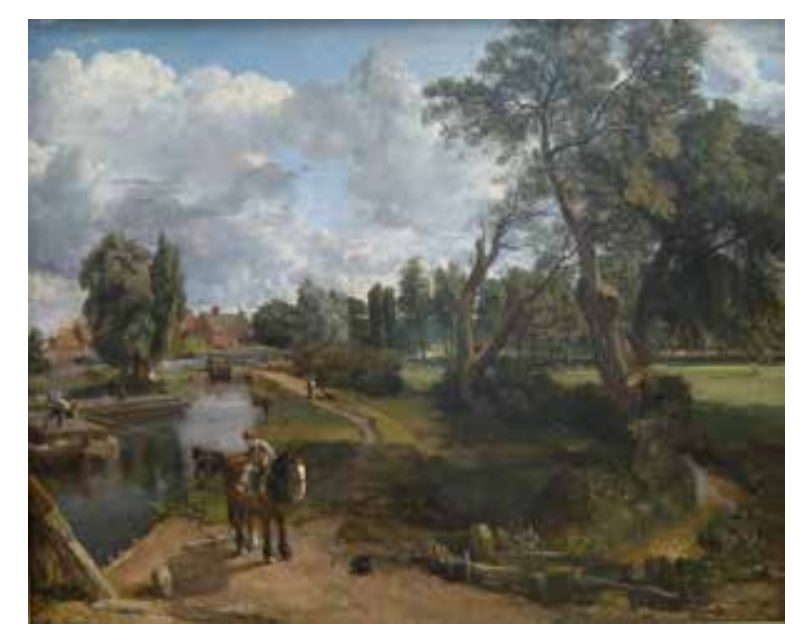

Acima [imagem 49], John Constable. Flatford Mill (Cena em um rio navegável), 1817, óleo $\mathrm{s} /$ tela 50 × $60 \mathrm{~cm}$. Tate Britain, Londres

Fonte: https://www.wikiart.org/en/john-constable/flatford-mill-1817 estatuto do motivo, ou o lugar a ser registrado. Em diálogo com as idéias da poesia de Wordsworth, o romantismo naturalista de Constable é definido por Clark da seguinte maneira:

"Na sua maior obra, o naturalismo é levado a um nível mais alto pela crença de que desde que a natureza é a mais clara revelação da vontade de Deus, a pintura da paisagem, concebida com o espírito da verdade humilde podia ser um meio de exprimir idéias morais." (1961, p.104)

No entanto, a atitude de Constable é profundamente diferente da dos pintores das paisagens dos fatos, e seu naturalismo coloca a centralidade naquilo que denomina o "claro-escuro da natureza", uma "unidade dramática de luz e sombra [que] deve sublinhar toda a composição da paisagem e dar o tom dominante do sentimento com que a cena foi pintada"(1961, p.102) Haveria em Constable o princípio fundamental de subordinação de todos os "fatos" da paisagem a uma ideia pictórica geral. Tal ideia é sempre reafirmada por Clark, no mesmo sentido em que fala do "princípio geral da luz", que orientaria as melhores paisagens "ideais" e "dos fatos". E ela nos leva ao que seja talvez uma das questões chave à nossa reflexão sobre a representação da paisagem: o que confere "unidade” a uma paisagem? Como apreendê-la e traduzi-la em linguagem em meio à multiplicidade de coisas e de outras paisagens?

A esse respeito, é importante analisarmos a seguinte passagem de Clark sobre os êxitos de Constable:

"É tanto por este sentimento de unidade dramática como pelo sentido de frescura da natureza que Constable se distingue de seus contemporâneos. Reconhecia como verdade fundamental que a arte se deve basear numa só ideia dominante e que a prova de um artista é a sua habilidade para realizar esta ideia, enriquecê-la, desenvolvê-la, mas nunca a perder de vista e nunca incluir quaisquer incidentes, por muito sedutores 
Clark compreende que as convenções clássicas e ideais ajudam o pintor a realizar essas tarefas, mas que a visão naturalista e a fidelidade ao real ou factual dificultam a subordinação de todos os elementos pictóricos a uma ideia geral.

Como reiteradamente nos questionamos ao longo da pesquisa, e que nos é constantemente compartilhado pela literatura, há na sintaxe visual das paisagens um constante jogo entre forças antagônicas de expansão e recolhimento, entre ação e retração das formas. Há algum equilíbrio a ser conquistado entre a particularidade e o todo, de modo que a unidade da paisagem tanto pode ser "perdida" em seus pormenores, quanto só se efetivar em função deles. De modo geral, esse embate entre parte e todo se trata de uma das grandes questões da pintura, das linguagens artísticas e de certa forma de toda a comunicação, mas é interessante verificar que, em relação à paisagem, há especificidades da linguagem visual que se confundem com a própria experiência da paisagem.

Poderíamos conceber esta "ideia pictórica" geral ou "sensação" estética a ser apresentada e desenvolvida nas pinturas, de que nos fala Clark, como análogo à própria unidade perceptiva da paisagem, como aquilo que a caracteriza, apreende e dá sentido à sua representação. O pintor, ao escolher seu motivo a partir da observação do mundo visto, inicia seu trabalho por uma primeira operação de síntese: criar o desenho em que insere sobre um plano o conjunto de coisas que vê, em função de suas sensações e percepções visuais, e em função da própria forma de seu suporte. Na tentativa de desenhar e pintar aquilo que se vê na paisagem "real", é criada uma espacialidade imaginária estruturada por um tipo específico de coesão, que é singular a cada paisagem pintada, correspondendo a uma experiência singular de cada olhar diante de um determinado local.

Ao escolhermos esta e não aquela vista para produzir uma paisagem, algo do fundamento desta "ideia pictórica" a que devemos ser fiéis, como supostamente foi 
Constable, já está desenvolvido. Por mais invisível, impalpável ou atmosférica que seja essa ideia geral, ela é fundada em um dado elementar da percepção visual. Se assumimos que, de certa forma, o pintor vê a paisagem à medida em que a pinta, ele não pode negar que, antes de começar seu desenho, viu algo que "se desenhou" em sua visão privada. Por mais que um artista intencione partir do acaso, sem um projeto, sem escolher motivos e vistas específicas para criar sua pintura, mas deixando que a ação da linguagem pictórica e gráfica dite os caminhos do olhar, ele viu "algo" que o moveu em direção à sua criação, ainda que o tenha visto dentro de sua memória visual, ou da própria imaginação.

Se formos mais a fundo na nossa hipótese, a característica unificadora, o princípio geral que delimita para o artista o que vem a ser a paisagem que constrói no quadro, se origina aquém de uma reflexão em que se possa racionalizar e deliberar sobre esta ou aquela qualidade da luz ou da sombra. É à medida que o artista constrói sua paisagem que ele pode apontar para uma ou outra qualidade visual, que dá unidade e sentido expressivo a uma sensação referida ao recorte de mundo que se quer paisagem. Essa qualidade unificadora provavelmente se alterará, em alguma medida, durante o trabalho de pintar, mas ela já está presente de alguma forma na configuração básica e nas primeiras escolhas do desenho. De maneira vulgar, poderíamos dizer que o próprio "enquadramento", ou "recorte" que se opera na composição das paisagens, já dá sentido a um princípio geral que se coloca à imagem. O que não quer dizer que o fundamento visual da paisagem seja somente seu arranjo formal e sua geometria. Como tudo o que vemos se faz ver pela luz, luz e sombras, como elementos unificadores, já estão presentes nesse primeiro "nascimento formal", que caracteriza as escolhas básicas do motivo, de seu enquadramento, de sua disposição espacial esquemática, esta última invariavelmente condicionada pela geometria do plano de representação.

O que se pretende sublinhar aqui é a enorme dificuldade que temos em precisar o 
que vem a ser o "princípio unificador" e a "ideia pictórica central" das paisagens, ao qual tudo o mais deve ser subordinado. A concepção de boa pintura de Kenneth Clark, que costuma convergir sempre para o princípio geral de luminosidade, parece ser evidentemente um dos aspectos centrais, mas ela deixa a desejar quando consideramos a multiplicidade de elementos gráficos de que se compõem as representações de paisagem, parecendo um tanto simplificadora para a tomarmos como principal critério de apreciação. Quando vemos uma paisagem de Constable, parece reducionista eleger uma característica fundamental e verbalizá-la com precisão. Tudo o que podemos dizer é que, se há um princípio fundamental ao qual todas as coisas pintadas nas paisagens de submetem, sua qualidade talvez não seja da ordem do conceito e das sensibilidades líricas ou literárias.

\section{A unidade atmosférica}

À unidade sutil que define as paisagens, em muitos casos equivale a noção metafórica de "atmosfera". O uso corriqueiro da palavra, que parece ser sempre empregada para designar algo pouco definível, dada a imprecisão de seu significado em termos visuais, em certa medida tornou-se um clichê. Em termos de um certo "realismo", atribui-se efetividade à representação da paisagem, de sua ambiência singular, ao dizer que se "captou a atmosfera", "captou-se aquele não sei o quê", que define uma paisagem. Contudo, o uso do termo para a paisagem é contingencial, na medida em que ele se aplica à pintura em geral, e confunde-se com uma série de outras qualidades", tais como o uso da "cor atmosférica" (em oposição à "cor local”), o "princípio unificador" ou "ideia pictórica" de que fala Clark.

No tocante à teoria da paisagem, o filósofo Georg Simmel (2013), no início do século XX, em seu estudo Filosofia da Paisagem ${ }^{7}$, colocou o problema da representação

6. Mais recentemente, assim como a própria ideia de paisagem, diluiu-se o significado metafórico da atmosfera: fala-se em atmosfera sonora, paisagem sonora etc.

7. SIMMEL, Georg - La tragédie de la culture et autres essais, Paris: Editions Rivages, 1988 - In: Paisagemtextos - vol.1, trad. e org. Vladimir Bartalini. São Paulo: Fauusp, 2013. 
da paisagem sob os termos de uma unidade que a defina. Simmel procura compreender a operação de delimitação inerente à paisagem, aquilo que a torna singular em relação à totalidade da natureza, o que, a princípio, parece contraditório;

"A natureza, que no seu ser e no seu sentido profundos ignora toda individualidade, é remanejada pelo olhar humano - que a divide, formando em seguida unidades particulares - em individualidades batizadas de paisagens." (SIMMEL, 2013, pp. 2021)

Simmel define esta singularidade de cada paisagem como uma característica atmosférica, algo que que lhe dá contornos efêmeros, invisíveis e acolhe a totalidade, o ilimitado, o infinito no finito. A operação do artista seria, portanto, uma depuração da infinitude de detalhes que se apresenta na natureza, a ação de "subtrair ao fluxo caótico e infinito do mundo, tal qual ele se dá, de imediato, um pedaço delimitado, apreendê-lo e constituí-lo como uma unidade que, a partir de então, encontra em si o seu próprio sentido e corta os laços que a ligam ao universo para atá-los mais fortemente a si” (2013,p. 22)

A essa unidade formal atmosférica da paisagem Simmel chama Stimmung, palavra alemã que remete à ideia de "estado de alma" ou "estado psíquico", da qual cada paisagem seria dotada e que, simultaneamente, se funda na subjetividade e afetividade de cada espectador desta paisagem. Por isso, Simmel compreende o sentimento subjetivo do espectador como uma realidade objetiva indissociável da formação objetiva da paisagem que o desencadeia. Desta forma, a Stimmung de cada paisagem se reportaria somente à sua própria unidade formal e a nada mais, sendo seu caráter intangível pelos "conceitos gerais da sensibilidade lírico-literária. A Stimmung autêntica e individual, própria de uma paisagem, não se deixa designar por tais abstrações, assim como sua própria visão não se deixa descrever com o auxílio de conceitos." (2013, pp. 26-27) 
A abordagem de Simmel, portanto, representa um ponto de inflexão caro à nossa pesquisa, pois investe o fenômeno paisagístico de uma coexistência fundamental com a subjetividade e a sensibilidade, caracterizando um movimento em direção ao sentido fenomenológico da paisagem, como meio de expressão e comunicação entre interioridade e exterioridade.

É difícil precisar se a origem do uso do termo por Simmel se funda na tradição da pintura de paisagem, mas tal hipótese parece provável. Nosso objetivo com essa informação é, contudo, refletir sobre o quanto são intercambiáveis as noções referentes às qualidades da pintura e as noções referidas ao caráter da paisagem. O debate estético parece insistir em submeter a paisagem à natureza indefinida das qualidades pictóricas, com a imprecisão de que falou Erwin Straus (2013, p.58). Certo é que a conexão entre a paisagem e a pintura parece de tal modo originária, que é necessário tomar cuidado e certo distanciamento crítico para saber sobre qual delas estamos falando.

\section{3. da sensação à impressão}

O episódio do naturalismo romântico em torno das figuras de Constable e Turner abriu as portas para uma experimentação cada vez mais livre em relação à técnica da pintura, de modo que a agilidade e desenvoltura do trabalho do pintor na busca pelo registro da percepção viva, em ato, da paisagem pôde trazer uma renovado olhar para a unidade e as qualidades da luz. A maneira como somos impressionados pela paisagem passou a nutrir uma busca pela sensação visual, o naturalismo da pintura de observação ao ar livre passou a ser cada vez mais valorizado. Pintores como Theodore Rousseau e 
Ao lado [imagem 50], Camille Corot, $A$ Ponte em Narni, 1826, óleo s/ papel montado. $34 \mathrm{x}$ $48 \mathrm{~cm}$. Louvre, Paris

Font: https://commons.wikimedia.org/wiki/ File:Jean-Baptiste-Camille_Corot_006.jpg

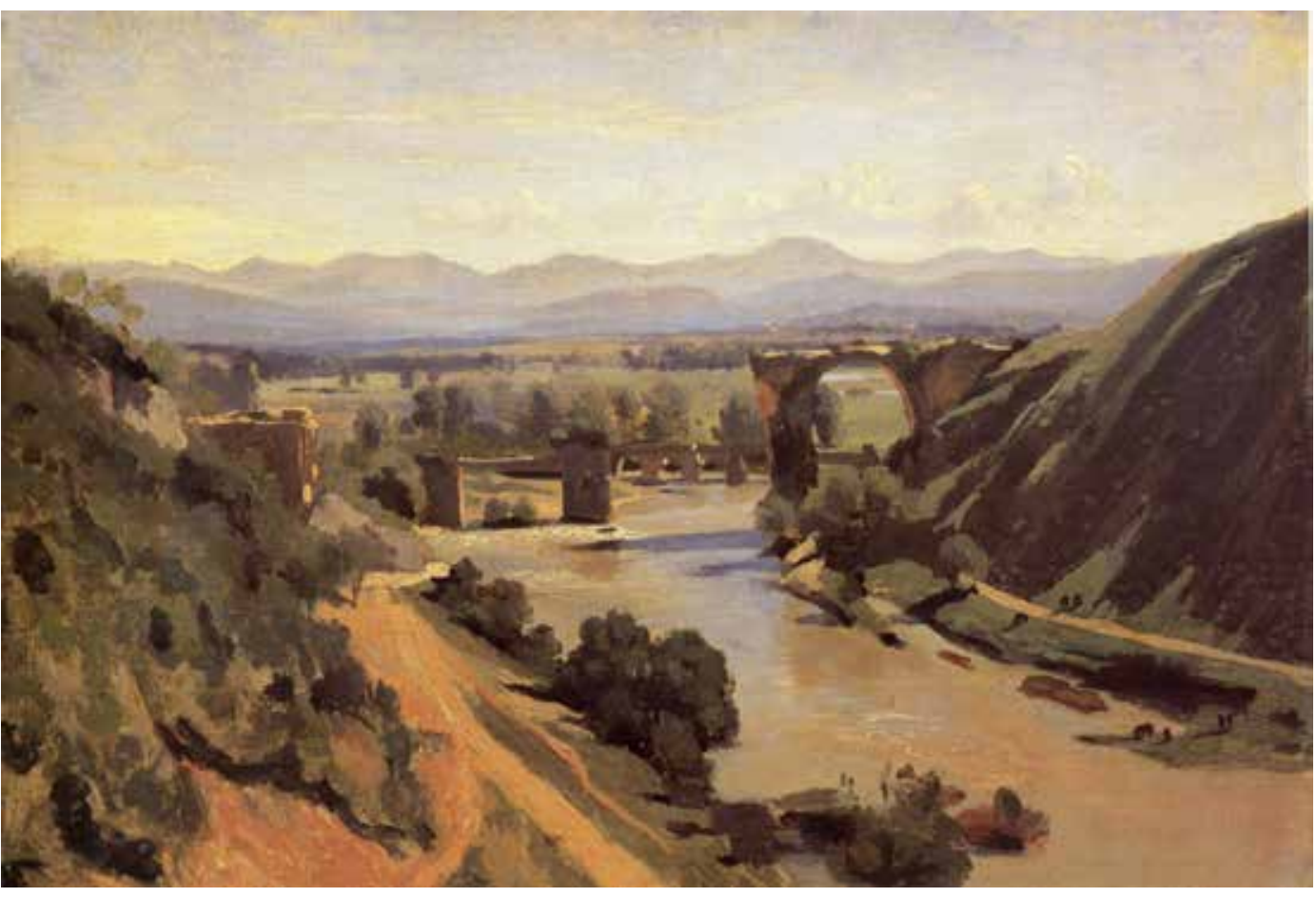

Camille Corot seguiram os passos de Constable no que toca à “crença absoluta na observação da natureza como base da arte.” Em escrito de 1856, Corot “[...] aconselha o estudante a confiar acima de tudo na primeira sensação: "Nunca abandonemos isso e ao procurarmos a verdade e a exatidão nunca nos esqueçamos de lhes dar aquele aspecto que nos impressionou. Não importa qual o lugar, qual o objeto; submetamo-nos à primeira impressão. Se nos sentimos realmente impressionados, a sinceridade da nossa emoção transmitir-se-á aos outros"”(1961, p. 111)

O mito de origem do impressionismo deriva de pronunciamentos como esse proferido por Corot, embora ele seja ainda um precursor desse movimento, e considerado 
mais como um "realista". Tratava-se de um contexto de dissidentes do academicismo, entre os quais se destacaram Honoré Daumier e Gustave Courbet. Este último particularmente acreditava fielmente no belo natural e o pintava com uma atitude quase devota. Uma de suas falas icônicas é referida por Clark:

"O belo está na natureza e encontra-se aí na realidade sob as formas mais diversas. Desde o momento em que é descoberto passa a pertencer à arte, ou antes ao artista que o sabe ver. Quando o belo é real e visível tem em si próprio a sua expressão artística. Mas o artista não tem o direito de ampliar esta expressão. Não lhe pode tocar sem se arriscar a desnaturá-la e, portanto, a enfraquecê-la. O belo, dado pela natureza, é superior a todas as convenções do artista."(1961, p.112)

Em divergência com o conteúdo temático classicista acadêmico, havia na pintura dos "realistas" também um temática da ética iluminista, democrática, que deslocava para a vida popular, do trabalhador rural e urbano a sua visão do belo natural. No entanto, o contraponto conceitual fundamental se dirigia à visão acadêmica da pintura, pautada na correção do natural ao sabor do ideal classicista. "Desenhar ou pintar o que se via era uma coisa simplesmente vulgar."(1961, p.112) A exclusão de pintores como Courbet e, posteriormente, dos impressionistas, dos grandes salões acadêmicos de arte atesta que a fidelidade ao realismo e à visão natural, sem idealizações, de fato demorou a ser aceita pela crítica de arte institucionalizada.

A pintura de paisagem moderna, ou seja, a impressionista, é consequência direta do olhar naturalista, combinada à iminente transformação da técnica da pintura, feita cada vez mais ao ar livre, sur le motif, e com maior velocidade, no intuito de se apreender a visão natural, a impressão do instante. Em meados do século XIX, a tecnologia propiciou aos pintores armazenarem suas tintas prontas em tubos, que lhes permitia pintar com maior desenvoltura no exterior do ateliê, sem que necessitassem tanta preparação quanto 

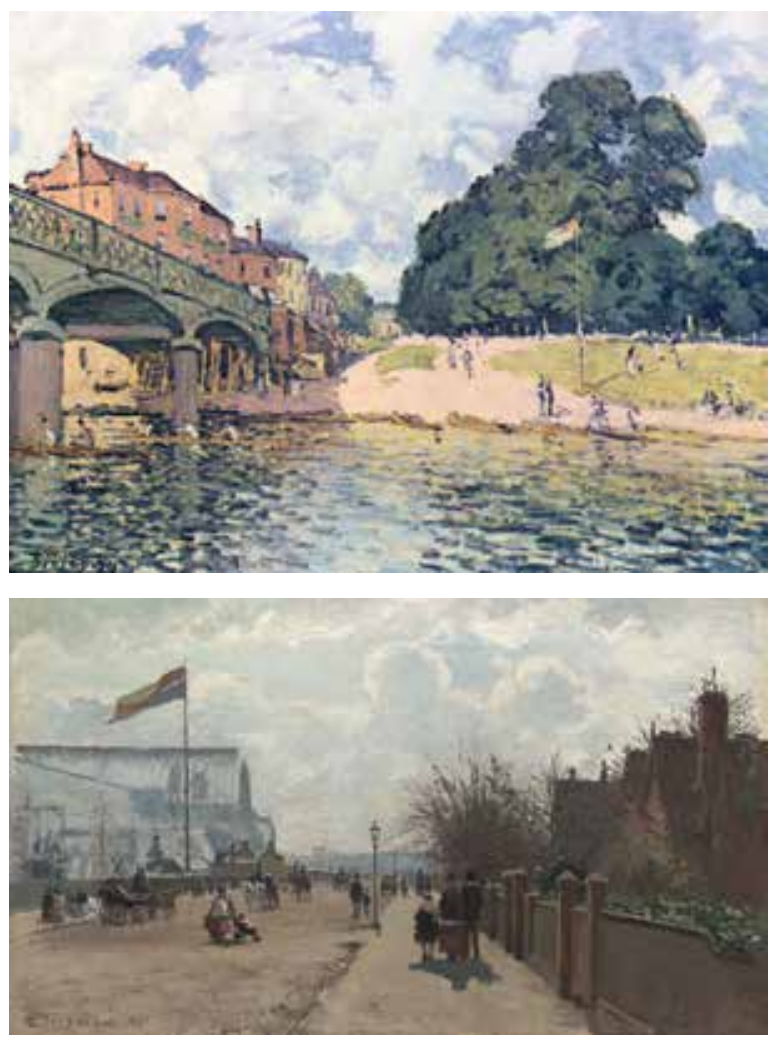

No topo da página [imagem 51], Alfred Sisley, $A$ ponte de Hampton Court, 1874. Óleo s/ tela $46 \mathrm{x}$ $61 \mathrm{~cm}$. Wallraf- Richartz Museum, Colônia.

Fonte:https://commons.wikimedia.org/wiki/ File:Alfred_Sisley_009.jpg

$\mathrm{Na}$ sequência [imagem 52], Camille Pissarro, $O$ Palácio de Cristal, 1871, óleo s/ tela. $47.2 \times 73.5$ $\mathrm{cm}$. Chicago Art Institute

Fonte:https://www.artic.edu/artworks/110541/ the-crystal-palace os antigos mestres. Se os pintores saíam para desenhar e pintar ao ar livre, o que realizavam in loco eram estudos e esboços que seriam reelaborados na pintura de ateliê. A pintura alla prima, que não se constrói pela sucessão de camadas de tonalidade e transparência, processo que caracterizava a pintura a óleo até então, aos poucos passa a ser executada com grande desenvoltura, ocupando o imaginário dos pintores com uma nova liberdade à pincelada, aos matizes de cor e tonalidades da luz. Uma maior leveza às massas de sombras, um frescor da visão que, a princípio, chocou o gosto da crítica. Mas, ainda assim, não podemos afirmar que a visão moderna da paisagem se deveu somente à prática da pintura ao ar livre. A este respeito, Clark nos questiona:

\footnotetext{
"Até que ponto esta frescura e este choque eram devidos ao fato de os pintores pintarem ao ar livre? As opiniões variam neste ponto. Houve uma época em que era usual atribuir grandes vantagens a este processo, e como reação, Sickert e outros recentes teóricos da arte, têm tentado defender a opinião de que toda a boa pintura é a feita no atelier, A verdade é que quando um artista desenvolveu um espírito pessoal consistente é difícil saber quando pintou diretamente da natureza."(1961, p.116)
}

$\mathrm{O}$ argumento de Clark é de que, em alguma medida, grandes pintores de paisagem como Claude Lorrain e Constable faziam muitos estudos ao ar livre para construir suas pinturas, e tal prática se deu em diversas épocas e lugares diferentes, mas o que criou a pintura moderna de paisagens era uma nova maneira de olhar. "Era portanto uma maneira de ver e não o fato físico de pintar ao ar livre que tornaram tão espantosa a escala de tons dos impressionistas"(1961, p.117) As pinturas de Sisley, Pissarro e Monet da década de 1860 apresentam uma qualidade de tons quase fotográfica e há possibilidade de que, inclusive, a recém-adquirida linguagem da fotografia já tenha influenciado a visão desses pintores. Para Clark, os impressionistas teriam, entre 1860 e 1874 , alcançado “[...] o naturalismo 
Ao lado [imagem 53], Benjamin W. Leader, Inundação defevereiro, c.1881.óleo s/ tela. 121.9 x 183 $\mathrm{cm}$. Birmingham Museums

Fonte:http://www.bmagic.org.uk/objects/1914P308

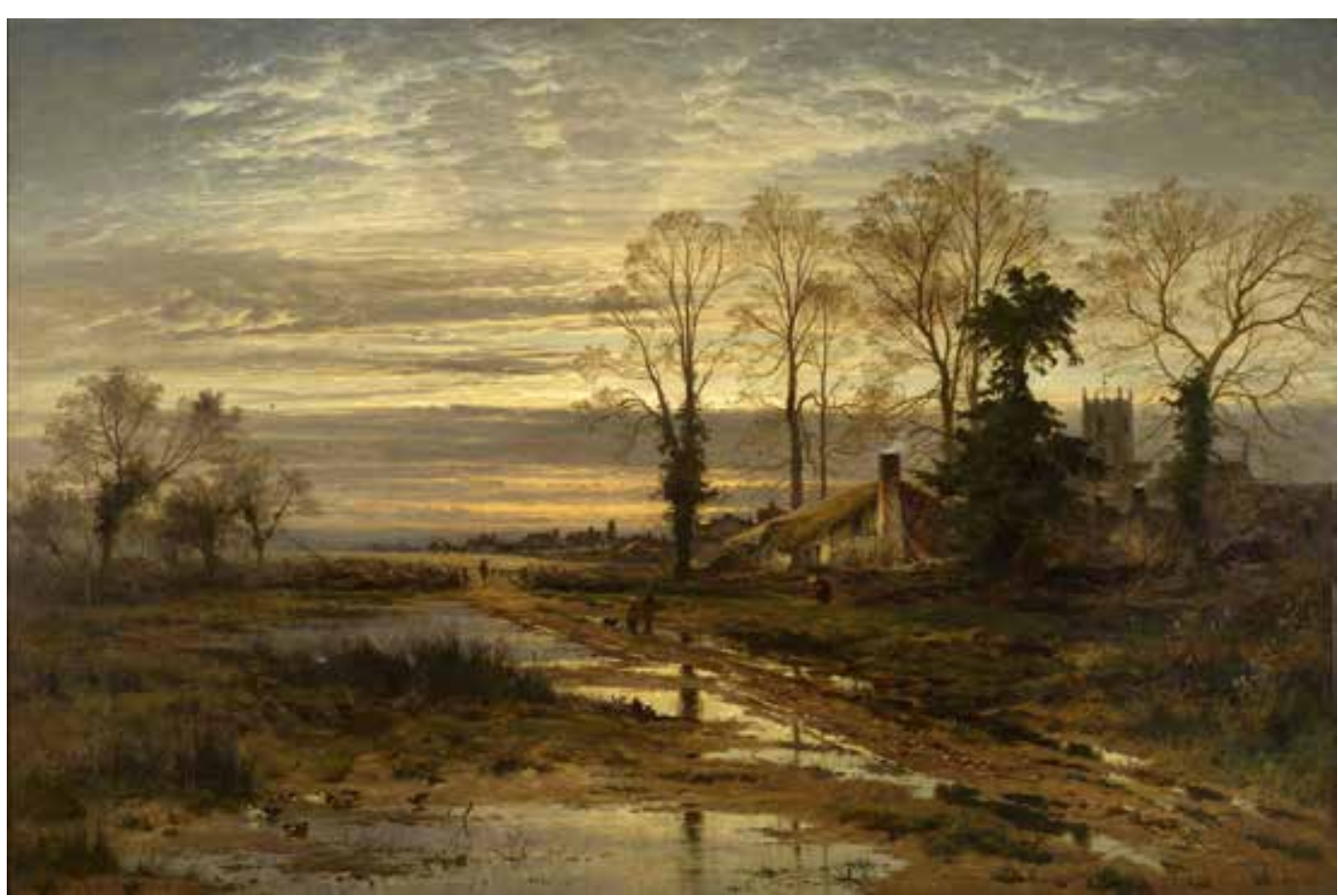

mais completo que foi realizado na arte" (1961, p.117). Para o autor, a produção de tais pintores nesse período seria tão próxima à impressão visual que superaria, pela vida e pelo brilho de suas luzes, a veracidade das paisagens dos fatos.

Ao falar dos maus exemplos da pintura naturalista, Clark cita o pintor B.W.Leader, que seria um bom exemplo do "falso naturalismo", e, novamente, nos deparamos com a relação entre o todo e as partes como elemento fundamental da tradução da experiência das paisagens:

“[...] a cor de Leader que é falsa e degradada [...] não há nela nada da unidade da atmosfera daquele invólucro geral da luz (para usar as palavras de Corot), que é a 
essência do verdadeiro naturalismo. Aí não há qualquer unidade. A natureza não foi compreendida como um todo, foi descrita pedaço a pedaço. Leader pensa ainda que o mundo é composto por um certo numero de "coisas" que têm de ser tratadas separadamente."(1961, p.118)

Comoàsvezesémais proveitoso estudarmos umaideia por seus exemplos negativos, nos detenhamos um pouco sobre esta pintura. Segundo Clark, "Os contemporâneos de Leader acreditavam que as suas paisagens eram tão verdadeiras quanto fotografias.” (1961, p.118) O exemplo acima nos mostra uma imagem em que temos de nos esforçar para distinguir mais do que alguns matizes de verde, tons terrosos e ocres, além do alaranjado róseo e o azul do pôr do sol. Em primeiro plano, todos os valores estão rebaixados, de modo que a paisagem assume uma unidade de tom e de luz convincente e expressiva quanto à atmosfera de sol poente. Contudo, há incongruências da luminosidade em meio ao excesso de informação visual e detalhes registrados, como se o pintor se houvesse sucessivamente apaixonado por alguns dos detalhes ou por uma determinada porção da pintura, e, à medida que passava da fatura de uma a outra, perde-se o sentido da expressividade que buscava transmitir.

O "falso naturalismo", segundo Clark, erra ao conceber a construção pictórica da paisagem como um dispositivo de coisas que se arranjam e encadeiam no espaço. Já o "verdadeiro naturalismo" seria, então, uma visão mais "holística", em que a paisagem pintada é construída de modo que seus elementos visuais se relacionam entre si, cumprem sua função na composição, mediados por uma qualidade específica que, por meio do modo de ser da luz, abarca toda a visualidade. Em outras palavras, trata-se de pensar mais a paisagem enquanto pintura, e menos enquanto "realidade", não pintando um arranjo de coisas do mundo visível segundo um ideal de paisagem. O exemplo de Leader nos mostra uma paisagem em que a luz não se pronuncia de modo convincente, e, de fato, há muito 
pouca luminosidade; há um foco de luz no reflexo da área alagada, mas a luminosidade do céu não corresponde a ele.

Nem todas as paisagens necessitam ter uma luminosidade uniforme, e é justo que poderia ser a intenção de Leader nos mostrar justamente a incongruência entre modos de aparecer da luz em sua pintura, mas trata-se de um grande desafio ao pintor realizar tal objetivo de modo que toda a pintura contribua para afirmar sua intenção. Neste exemplo da Inundação de Fevereiro, vemos justamente que, para além de questões de desenho e composição, a cor e os infinitos contrastes de luz e sombra são pouco eloqüentes e pouco se relacionam, pronunciando-se somente quando detemos o olhar sobre um ou outro detalhe. Se o pintor buscava mostrar-nos uma luz baixa, de poucos contrastes, ele não foi capaz de criar com sua pintura uma atmosfera de cor e luz que corroborasse expressivamente esta qualidade, e que conferisse sentido à forma como a luz incide sobre as casas à direita e sobre outros elementos formais do quadro. Por melhor que estejam pintados os detalhes e a textura da vegetação que margeia a enchente sobre a estrada, falta alguma vida e sentido à sua aparência, e eles em nada dialogam com outras áreas da pintura.

Há uma série de sutilezas da técnica e da poética da pintura cuja tradução literal é de tal modo difícil, que buscamos evitar maior aprofundamento da análise das razões pelas quais a pintura de Leader não atinge a qualidade paisagística "verdadeiramente naturalista”. Nossa intenção aqui é buscar compreender o que a crítica entende como maus exemplos de um mesmo objetivo em relação à paisagem. Se há algo de evidente, é que Benjamin Leader de fato é um artista menor em comparação à qualidade dos exemplos de naturalismo expostos até aqui.

O que interessa à nossa pesquisa é identificar critérios de apreciação que norteiam a representação da paisagem na arte, quais as formas e modelos estruturados ao longo da história, e de que maneira eles estão configurados em nosso imaginário paisagístico 
constituído, à medida em que analisamos as imagens produzidas em nosso estudo empírico. Se as paisagens do córrego Pirajuçara têm algo das paisagens dos séculos XVII ao início do XIX, elas se parecem muito pouco com a pintura impressionista, pois não captam uma sensação de luz instantânea e tampouco têm o frescor das cores e da pincelada impressionista. Sem nos adentrarmos nas razões técnicas desta filiação, limitemonos a dizer que nossas pinturas têm uma vocação naturalista, uma vez que efetuam um registro "realista" dos fatos e detalhes da paisagem, mas sem que se tornem propriamente fotográficas. A luz, as cores, a textura e a profundidade são construídas de modo que é impossível afirmar que registrem uma só impressão da luz, pois a luz nelas é demasiado ficcional. Se há efetivamente uma unidade na luz destas pinturas, ela funciona mais sob os termos da idealidade do que como verossimilhança à sensação óptica.

A crise do naturalismo impressionista teria sido desencadeada pelo esgotamento criativo, o lugar comum que a técnica e o olhar da "visão natural" de Monet, Sisley e Pissarro logrou conquistar. O desafio enfrentado por esses artistas é tamanho, que Clark não hesita em dizer que:

"A paisagem realista que os ignorantes creem ser a mais simples forma de pintura, é na verdade uma das mais inacessíveis em que o sucesso é mais raro e mais precário. Até mesmo um pintor tão bem dotado como Sisley, sofreu um declínio gradual de convicção. Monet e Pissarro, mais conscientes do seu dilema, tomaram um caminho diferente. Forçaram-se a ver na natureza aquilo que o olhar comum não pode ver, ou pelo menos não pode analisar - a rede de cores puras de que se compõe a luz. Teoricamente mantinha o princípio do naturalismo ou levavam-no ainda um pouco mais longe; mas na realidade rejeitavam as limitações da visão natural em favor de uma transposição que lhes permitiria maior liberdade criativa." (1961, p. 119)

Esta transição em que vemos o declínio do naturalismo em tais pintores marca o nascimento do autêntico impressionismo, tal como se notabilizou popularmente, na 
pintura madura de Monet e Renoir, em que vemos um brilho e uma fatura de pinceladas de cor pura nunca antes equiparada. Foi esse o impressionismo que mobilizou uma série de pintores já maduros como Manet, a dar uma guinada crucial no sentido da arte de vanguarda. O declínio do impressionismo se deu, segundo Clark, a partir da década de 1880, quando Monet e Renoir passam a dedicar-se a pinturas cada vez mais coloridas e obsessivamente brilhantes. A respeito dessa decadência, o autor nos fala de algo que diz respeito à arte em geral:

"Há poucas coisas mais repousantes na arte do que a satisfação numa técnica recentemente adquirida. A excitação com que os impressionistas conquistaram a representação da luz pelo uso da paleta de cores puras, é semelhante à excitação com que os florentinos do século XV conquistaram a representação do movimento pela fluência da linha. Mas a arte, que depende demasiado da alegria da descoberta, declina inevitavelmente quando a técnica é dominada." (1961, p.121)

Com o desenvolvimento de sua autonomia formal, a linguagem impressionista afastou-se do naturalismo, à medida em que se mostrou pouco útil à renovação de seus motivos. Eles se restringiram, no caso de Monet, à aplicação das qualidades de sua poética em temas em que a luz é a mais brilhante possível: "Apenas o sol sobre a água ou o sol sobre a neve podiam servir inteiramente a visão prismática e a pincelada brilhante.”(1961, p. 122) A "promoção de meios a fins", então, manifestaria a decadência nas artes, e o autor reconhece que o impressionismo teve pouca duração e já está historicamente muito distante da arte de nosso tempo. Contudo, a "conquista da luz" seria o maior êxito do impressionismo, por retomar a tonalidade mais clara e o uso de cores mais puras e frescas, que havia se perdido na pintura europeia desde o Renascimento.

É interessante o papel dado à decoração no juízo do autor sobre a conquista da luz ocorrida no impressionismo, como nos mostra a seguinte passagem: 
"Desde que Leonardo da Vinci tentou realizar cientificamente o relevo por meio de serem sombras escuras, os quadros sempre tiveram a tendência de serem zonas escuras na parede.[...] Sentimo-nos gratos pelos quadros que temos nas nossas paredes (e claro que é aí que os quadros devem estar, e não nas paredes dos museus) serem agradáveis não só pelo que neles observamos como pela sua função decorativa. (1961, pp.123-24)

Tal aspecto interessa especialmente à nossa discussão, uma vez que o colorido das pinturas do córrego Pirajuçara certamente está aquém dessa luz e do colorido impressionista. Há neles uma tentativa, como a de Leonardo, de se conferir profundidade ao espaço e conferir volume pela construção pictórica em camadas, que se erguem do mais escuro para o mais claro. O impressionismo muda a concepção da pintura de paisagem na medida em que abdica da corporeidade tonal para tentar exprimi-la pelas tonalidades do colorido. $\mathrm{O}$ uso do colorido nas pinturas do córrego Pirajuçara não comunica tanto pela cor quanto pelo desenho ou pelo jogo de luz e sombra. É talvez essa característica, que se explicita no âmbito da técnica, a que melhor explica o caráter algo historicista, idealizado e romântico nestas imagens.

Por outro lado, esse parece ser mais um desdobramento da antiga querela entre disegno e colorito. A liberdade conquistada pela visão e pela pintura na figura do olhar impressionista se ampara também no desenvolvimento da filosofia e da estética desde o Iluminismo. A filosofia idealista endossava um desnível hierárquico entre forma e cor, “[...] mantinha que a forma era uma função do intelecto enquanto que a cor era uma função dos sentidos." (1961, p.124) Portanto, o impressionismo foi uma reação a essa postura estética intelectualista, que concebia a cor como uma característica secundária à forma dos objetos, uma vez que ela é subjetiva, e sobre a sensação da cor não se pode fazer ciência clara e distinta. Os desdobramentos teóricos destes dualismos entre o desenho e a cor, como 
o "linear x pictórico" de Heinrich Wölfflin", estão ainda presentes também na estética da pintura moderna do século XX, de modo que a tradição de pintura estabelecida pelo impressionismo prevalece até o início da arte contemporânea. Um índice da degeneração deste estilo moderno, ou seja, de tradição impressionista, que privilegia a poética da luz e da cor, é que ela também se tornou acadêmica.

Por mais que Clark se distancie historicamente do impressionismo, o historiador é de uma geração que viu a pintura de vanguarda se desenvolver baseada, em parte, na emancipação da cor e no surgimento do abstracionismo. O espírito da pintura de vanguarda, grosso modo, é difícil de se dissociar da reação libertadora ocorrida no impressionismo, que, à época em que Paisagem na Arte, lançado em 1949, foi escrito, desembocaria no expressionismo abstrato. Por isso temos que compreender que há em Clark certa reverência à tradição de sua época, que está toda fundada sobre os pilares do impressionismo, e não é estranho que ele demonstre sua predileção pelas qualidades da luz impressionista ao longo de toda a história das paisagens que nos conta. Estaria já em Hubert van Eyck o germe desta luz unificadora na paisagem moderna do impressionismo.

Se o chiaroscuro e os volumes de sombra de Leonardo ainda sobrevivem como ideal técnico da pintura, isso ocorre nas escolas de pintura acadêmica (o que não significa que hoje elas não englobem todas as tendências estéticas modernistas, incluso o expressionismo abstrato, que se diluiu em uma pintura decorativa comercial). As pinturas hiperrealistas, neoclássicas e "neotradicionais", presentes na pintura contemporânea, em sua maioria, são feitas por praticantes ávidos pela técnica da pintura e pelo estudo das tradições perdidas, que estão à margem do grande mercado e da crítica institucionalizada da arte, exercida ainda por uma geração pós-vanguardista e saudosa da pintura moderna. 
rio Pinheiros e do córrego Pirajuçara estejam à margem da tradição impressionista e da pintura moderna. Não tratamos aqui somente de uma escolha estilística, mas de um modo visual de se representar a paisagem com uma intenção realista. Todavia, busca-se nessas paisagens resgatar de forma anacrônica um modo antigo de se pensar a luminosidade do visível, que não corresponde à natureza das imagens modernas e contemporâneas. Se fosse uma pintura emulando o olhar impressionista, seria também anacrônica, mas ainda próxima do imaginário da visibilidade contemporânea. Esta visibilidade é a da cultura de imagens cinematográfica, do vídeo e da fotografia digital. Com elas aprendemos a ver de um novo modo, em que valores tonais e matizes de cor se mostram mais saturados e comprimidos do que eram antes da industrialização. A fotografia nos vem ensinando a ver e a imaginar relações de tonalidade e de luz e sombra de um modo desconhecido à visualidade anterior à arte moderna. $\mathrm{O}$ imaginário visual constituído pela cultura da imagem técnica atua de modo a estruturar modos de percepção afeitos a novas relações entre luz, sombra e cor, diferentes daquela do cidadão do século XVIII. Essa transformação vem ocorrendo desde os primórdios da imagem fotográfica e o olhar impressionista é uma das manifestações bem-sucedidas da linguagem visual expressar este novo olhar. Segundo ele, o mundo se mostra em sua vibração luminosa, em que formas perdem contorno e definição e contrastes se atenuam, como se cerrássemos os olhos para ver o mundo, o cacoete típico da caricatura dos pintores de boina e paleta na mão.

Afora tais questões técnicas, o que nos interessa é aquilo que o olhar préimpressionista nas paisagens do córrego Pirajuçara nos diz sobre a representação da experiência paisagística contemporânea. Talvez captar a sensação luminosa em ato não interesse à construção pictórica dessas paisagens. Nelas, concebe-se o registro da experiência visual da paisagem como construção ou montagem de diversas impressões e olhares. Ainda que as pinturas pareçam conter uma coerência de um determinado 
momento, a luz e atmosfera de uma mesma visada, é difícil ver nelas um instante singular. A paisagem que elas registram não é a da fugacidade, mas a da luz lentamente construída, camada a camada, de uma solidez vagarosa, parecendo estar parada no tempo, decantada por ele. $\mathrm{O}$ modo de construção pelas massas de sombras não confere a elas hiperrealismo ou qualquer característica fotográfica. Se é lícito dizê-lo desta maneira, é irônico que elas tenham algo de fotográfico na medida em que parecem ficcionais, fruto de um raciocínio de colagem. Apesar de que se registre nelas o mundo em seus pormenores e detalhes, é difícil dizer que há nessas paisagens a intenção de nos trazer uma "visão natural", uma sensação "fresca" das cores e da luz. Pelos enquadramentos, denuncia-se que o uso da fotografia como registro e modelo para construção da imagem é essencial a elas, mas nem por isso há nelas uma tentativa de reproduzir as qualidades da imagem fotográfica. Elas se aproximam mais dos desenhos do que da pintura moderna e das fotografias.

Por mais encantadora que seja a pintura alla prima, en plein air, trazendo a percepção visual viva, natural do motivo, ela esbarra em seus próprios limites expressivos, de modo a afastar-se da experiência, tornando-se mais um dos estilos de pintura. Clark nos coloca a reflexão sobre a limitação da "visão natural” em meados do século XX ainda nos serve para indicar razões para uma negação contemporânea do olhar impressionista:

"Sessenta anos passados pode parecer-nos que esta confiança no mundo físico era uma fraqueza fundamental. A arte relaciona-se com todo nosso ser, o nosso conhecimento, as nossas recordações, as nossas associações. Limitar a pintura a sensações puramente visuais é aflorar apenas a superfície do nosso espírito. No fim das contas talvez esteja certa a doutrina idealista, somos mais impressionados por conceitos do que por sensações, como o demonstrará qualquer desenho infantil. A suprema criação da arte é a imagem compulsiva. Uma imagem é uma "coisa", e o impressionismo tinha por objetivo abolir as coisas; na pintura, as imagens mais simples e mais duradouras são coisas contornadas por linhas, e o impressionismo aboliu a linha." (1961, p. 125) 
Tal conclusão assume a oscilação de um pêndulo histórico, em relação à paisagem, do âmbito da sensação para o do intelecto, e vice versa. Entre objetivismos e subjetivismos, empirismos e intelectualismos, a paisagem segue historicamente se mostrando inapreensível diante desses dois modos dualistas de pensamento que procuram explicar sua experiência e a linguagem que dela se constitui. Se concordamos que o "[...] o impressionismo não se dirige à imaginação", como quer Clark, ele constitui hoje parte da história de um imaginário das paisagens, do qual o artista não pode simplesmente se desvencilhar, assim como dos olhares naturalistas, idealistas, descritivos e simbólicos que o precederam.

É importante reafirmarmos que um dos grandes valores da historiografia da paisagem na arte proposta por Clark é justamente a sua autonomia em relação a uma temporalidade cronológica. Cada atitude do olhar em relação à paisagem, descrita em suas categorias compreende a duração de toda a história da paisagem, ainda que possamos localizar a predominância de um ou outro modo de representá-la em um determinado recorte temporal singular. Mas essa predominância será sempre parcial e contingente a uma determinada finalidade historiográfica. A "paisagem dos fatos” pode estar presente nas paisagens naturalistas, assim como traços da "paisagem dos símbolos" podem se manifestar na paisagem romântica ou expressionista. É nesse sentido que insistimos em estabelecer intuitivamente nexos entre as paisagens produzidas em nossa pesquisa e as diferentes atitudes de representação que foram caracterizadas ao longo da história, pois compreendemos ser em função da sobrevivência da memória visual que as paisagens vêm exteriorizando e estruturando um modo de ser de nossa consciência sobre a experiência sensível do mundo. 


\section{CAPÍTULO 4}




\section{De volta às margens do rio Pinheiros}

\section{4 - De volta às margens do rio Pinheiros}

Podemos dizer que a série de paisagens em gravura em metal apresentada no capítulo 2 estabeleceu parâmetros de um olhar específico para as margens do rio Pinheiros. Esse olhar se caracteriza, em geral, pela ênfase na percepção de horizontalidade colocada pela visão à margem do rio, assim como pela frontalidade assumida no desenho. Tais condições de visão expressam aquilo que é essencial à paisagem de um rio qualquer: o contraste entre dois estratos materiais - água e terra - e a presença de alguma "marginalidade”, a natureza da "beira". Não basta a existência de dois estratos, é necessário que o limite de um toque o limite do outro. Trata-se de uma relação elementar de adjacência e paralelismo entre dois estratos espaciais distintos.

Em termos gerais, podemos dizer que o jogo de forças entre verticalidade e horizontalidade é necessário à paisagem de qualquer rio, uma vez que ele assume a característica marítima ou oceânica à medida em que o horizontal elimina totalmente o elemento vertical. Ainda que existam rios tão largos a ponto de não deixarem que vejamos a margem oposta, é difícil dizer que a paisagem que deles se depreende, no âmbito de um imaginário cultural, comunica aquilo que compreendemos como rio, pois ela se aproxima mais da amplidão do oceano e de uma geograficidade litorânea.

Se há nessas paisagens do rio Pinheiros algo do rio universal, há também algo do rio particular, que é sua característica específica: aquilo que talvez possamos chamar de a "sua paisagem", aquilo que o distingue da ideia de qualquer outro rio. Esse algo singular se expressa, em grande medida, pela frontalidade, pelo posicionamento de um olhar ortogonal à linha do rio. E o que o conjunto de paisagens do capítulo 2 nos dava a perceber é talvez a sensação de um movimento linear, uma experiência da paisagem que reforça a visão sucessiva de diversas porções de margem correndo paralelamente a um direcionamento. 
O conjunto dá a entender que o rio é visto em viagem, e não por alguém que habita ou repousa às suas margens. Esta característica expressa bem a condição urbana e artificial de tal rio: a canalização de seu leito, que uniformiza suas beiradas, mantendo mais ou menos estável a distância entre suas margens; assim como o fato de que estas margens não existem para o indivíduo estar, e sim para correr. Nessa paisagem, só o deslocamento é possível, e a lógica das vias expressas para carros que percorrem sua extensão se aplica também ao contato mais imediato com o rio: há uma faixa de espaço reservada para a linha de trem, que segrega a autovia da ciclovia, que é a faixa de espaço que nos proporciona a experiência visual expressa nas nossas imagens.

Se, num primeiro momento, as imagens se pautavam pela presença de um elemento de cruzamento ou travessia desse rio, protagonizada pelas pontes, colocando em evidência a situação espacial que resulta do embate entre dois sentidos de movimento, o desenvolvimento da série de vistas privilegia, num segundo momento, aquilo que a própria margem comunica, sem que haja a presença de um objeto construído, como a ponte, para que o lugar seja eleito como um ponto de vista que se faça notar. Ou seja, de certa forma, o ímpeto de registrar o "nó" paisagístico engendrado entre a margem e a ponte cede à planaridade da margem à medida em que o olhar passa a se aprofundar e a buscar ver a diferença naquilo que, à princípio, parecia indiferente, uniforme e de pouco interesse, como mera continuidade de um todo regular. Antes, era como se a margem, por sua aparente regularidade uniformizada, se diluísse em um espaço indiviso, em que somente uma interrupção brusca, como a ponte, justificasse um olhar paisagístico. À medida que a pesquisa se desenvolve, é, no entanto, nessa uniformidade da margem que passam a se mostrar os espaços singulares.

Quanto a esse aspecto, a gravura seguinte [54] marca a continuidade com uma ênfase radical na horizontalidade e na frontalidade da visada, que já se anunciava na última 
Na página seguinte [imagem 54], Parque do Povo (Córrego Iguatemi), 2017, água forte e água tinta sobre papel de algodão, $7.5 \times 31.5 \mathrm{~cm}$ gravura apresentada no segundo capítulo (imagem x, p. Xx). Ainda que haja a confluência de uma série de elementos cujo interesse visual justifica uma tentativa de agrupar e dispor tudo em uma mesma faixa de visão, tudo se dá em função de faixas frontais, e toda a imagem é construída em função delas. Salvo a exceção da boca do córrego Iguatemi, que deságua no rio no canto esquerdo da imagem, indicando brevemente uma perspectiva em direção à profundidade do subsolo, tudo é modulação de uma horizontalidade; contrabalançando-a, a barcaça levemente enviesada atracada à margem constrói alguma profundidade em direção ao primeiro plano. Mas tudo está contido na margem, não havendo concessão ao que não se mostra frontalmente e ao olhar que vê à distância; o céu não se mostra, senão como luminosidade, e qualquer visão longínqua está bloqueada.

Outro aspecto que expressa uma transformação no olhar dirigido às nossas paisagens do rio Pinheiros é um novo tratamento gráfico dado aos fatos da paisagem: ampliou-se a gama de cinzas que criam as sensações de luz na vegetação e nas superfícies, não mais havendo a profusão de hachuras que víamos nas primeiras gravuras. De certa forma, o tratamento se tornou menos "linear" e mais "pictórico". As linhas da gravura mostram-se cada vez mais apagadas, sendo integradas aos contrastes de cinzas granulados das manchas da água-tinta. Os contrastes de luz tornaram-se menos agressivos do que nas primeiras imagens, e a paisagem como um todo assume uma atmosfera luminosa mais escura, menos "solar".

Na gravura que segue a sequência cronológica, mas também narrativa e espacial (no sentido propriamente geográfico) colocada pela série, vemos a continuidade de um olhar que preza mais pela frontalidade: ainda que se trate de uma ponte, ela passa por cima de nós, além do que a imagem dá a ver, e o observador se situa sob a sua sombra. Do prolongamento e sentido de movimento dessa ponte, só podemos ver um breve índice, que é a área escura que se observa sob o vão da estrutura, um pouco à direita, fazendo uma curva 


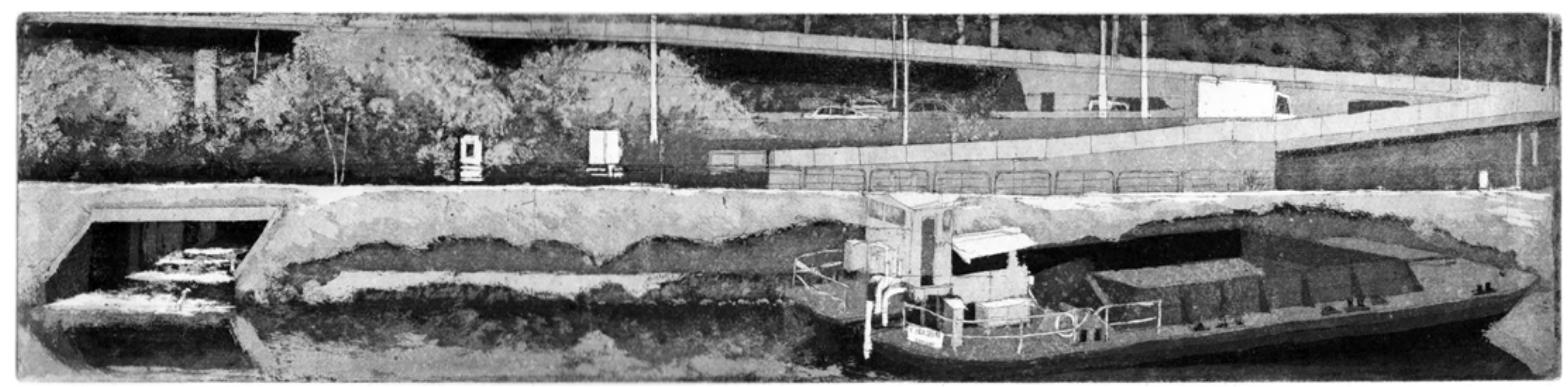


Na página seguinte [imagem 55], Ponte Estaiada, 2018. Água forte e água tinta sobre papel de algodão, $11 \times 30 \mathrm{~cm}$. no sentido de uma profundidade. O caráter singular desta visada é também o fato de ser a única em que se vê uma primeira faixa horizontal em um primeiro plano inferior, anterior à água do rio, nos mostrando a grama iluminada pelo sol, a zona mais clara da imagem. Este primeiro plano traz a sensação de uma maior distância entre o observador e a margem oposta, e temos aqui uma espacialidade um pouco alargada em relação às paisagens anteriores. Ainda assim, a ampliação do "campo visual” e da sensação de distância que se coloca é discreta, e o céu está bloqueado, senão no canto superior esquerdo, praticamente imperceptível.

Novamente, temos valores mais acinzentados, contrastes menos agudos entre tonalidades de cinza e branco, e uma maior autonomia das manchas em relação às linhas; as superfícies estão menos definidas graficamente e há uma sensação visual cada vez mais embaçada, granulosa, assim como no reflexo da água do rio, em que manchas bruxuleantes de preto e cinza, expressam uma liberdade de formas algo expressionista e ainda inédita à série. A característica eminentemente pictórica nestas gravuras se articula com um novo momento da viagem pela paisagem do rio, coincidente com a incursão pela paisagem do córrego Pirajuçara, caracterizando um novo olhar, e assim, uma nova série dentro de um conjunto maior.

Não se trata aqui de estabelecer uma hierarquia evolutiva da técnica no desenvolvimento da pesquisa, segundo a qual de um olhar gráfico se passaria a um olhar pictórico. É necessário compreender que as próprias qualidades e características das paisagens como gravura são o motor de uma transformação do olhar: de um interesse no contraste entre o concreto e o "mato marginal" que se apresenta junto às pontes que cruzam o rio, passa-se a ver cada vez mais o jogo de luzes, sombras e texturas da vegetação e da terra que revestem, como pano, um esqueleto de concreto sob o qual viajam córregos ocultos. Se as pontes engendram pontos notáveis em uma paisagem linear, o que se dá entre esses pontos “dignos 


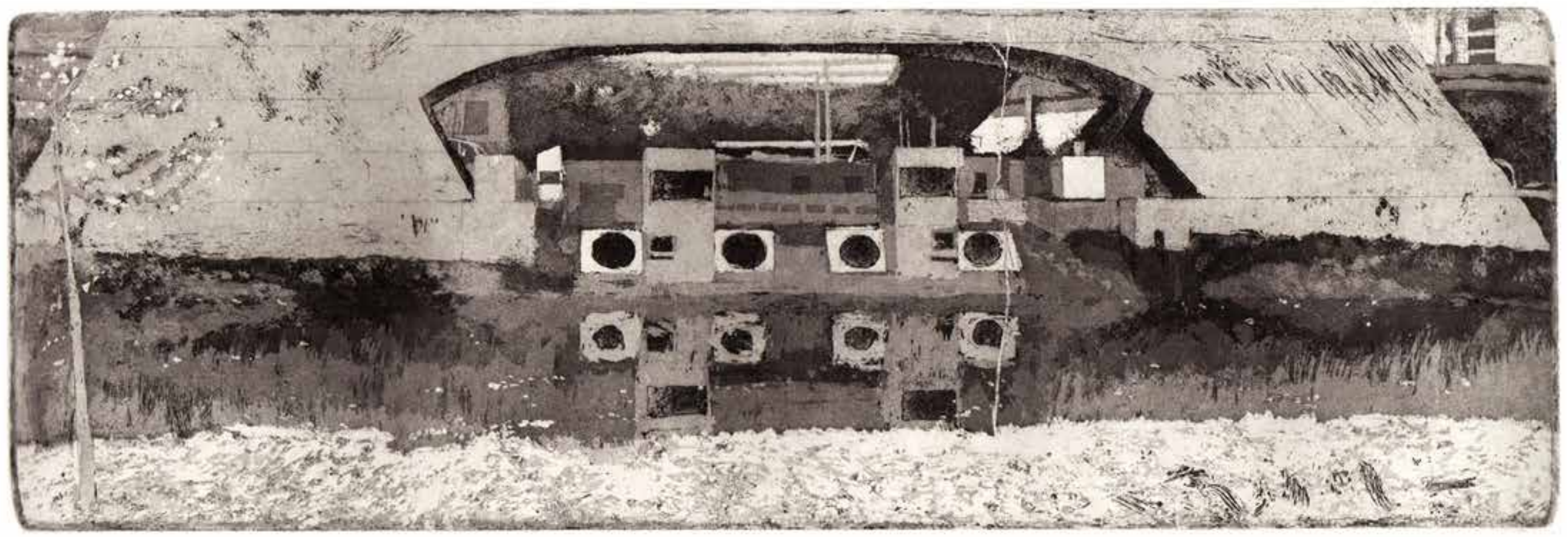


de nota" é, talvez, aquilo que caracterize primordialmente tal paisagem. Portanto, trata-se de uma sutil mudança de registro do interesse visual, e as últimas gravuras já trazem um prenúncio desse novo olhar, que encontra na pintura condições expressivas favoráveis à descrição de um outro foco imagético, que talvez não fosse satisfatoriamente exprimível pelos meios da gravura.

Por assim dizer, não nos interessa afirmar que de uma ou outra técnica resulte maior ou menor qualidade artística e adequação dos meios aos fins, nas paisagens apresentadas, mas que a combinação entre a experiência do rio empírico com a da sua representação continuada, em vistas seriadas, trouxe a necessidade de uma outra técnica. É por esta e outras razões que reafirmamos: nosso interesse nesta pesquisa é trazer à tona o quanto a paisagem como ideia é construída em função de seu modo de expressão, sendo sempre um meio termo entre o mundo que se dá a ver e a linguagem de quem o torna novamente visível; não há a paisagem puramente imaginada, sem qualquer referencial empírico, assim como não há uma paisagem "pura" e atual, fruto de uma experiência "imediata”. A paisagem se constrói entre a experiência e a linguagem, não existindo como algo "em si". O mundo visto, por si só, não equivale à paisagem, tanto quanto a paisagem não equivale à arte.

As primeiras paisagens pintadas do rio Pinheiros se articulam diretamente com as questões colocadas às últimas gravuras em metal: investiga-se a frontalidade total da visão, compondo uma paisagem da margem a partir da ordenação compositiva de elementos visuais singulares, como as bocas de córregos que confluem para o rio. Mas, como seria de se esperar de uma pintura, nelas as cores da vegetação assumem uma importância que não têm nas gravuras em metal, de modo que a própria vegetação se coloca também como evento singular em meio à "uniformidade" da margem. Há pontos em que, não de maneira acidental, vemos aglomerações de vegetação, uma intensificação da cobertura verde 
que coincide com elementos marcantes, como as bocas de córrego. Há um tratamento paisagístico desses pontos, e não se sabe quão intencionais, projetuais ou estéticas são as razões de tais ocorrências. É certo que há uma vocação natural para que a vegetação se intensifique e se aproxime ao redor dos corpos d'água, mas também é certo que o paisagista encarregado desta margem buscou, de alguma forma, dar maior "proteção" ao encontro das águas, revestindo a confluência do córrego enterrado com o rio de sombra, como a tornar tal "evento hidrográfico" menos abrupto, atenuando-o, civilizando-o com paisagismo.

Decerto que há um misto de razões, intencionais e fortuitas, para que ocorra essa intensificação paisagística em torno do escoamento dos córregos no rio; salvo algumas exceções, é uma característica que ocorre ao longo de todo o trecho que percorremos em nossa pesquisa; e desde a primeira imagem esta característica se mostra, na confluência dos córregos Pirajuçara e Jaguaré com o rio Pinheiros na gravura Cidade Universitária do capítulo 2 [imagem 16, pagina 69].

É desse modo que o projeto de paisagismo existente nestas margens se coloca como assunto, e uma das questões colocadas à pesquisa é a de ponderar até que ponto ele pode se tornar o protagonista destas paisagens. Não é nossa intenção analisar as qualidades ou, pior, tecer elogios à realização paisagística que adorna este rio. Pelo contrário, é justamente o fato de o rio ser tratado como uma paisagem que revela uma contradição significativa: trata-se de uma maquiagem, um paisagismo superficial que em quase nada se presta à sua condição fluvial e à reabilitação ambiental, seja enquanto vida ecológica e também quanto à função social deste rio urbano morto. Vende-se uma visão de rio esteticamente agradável em pontos discretos de sua extensão, coincidentes com as vistas que se pode ter a partir das estações da linha do trem, mas nada disso é capaz de torná-lo um espaço de fato menos decadente.

Em relação ao desenvolvimento da pesquisa, as pinturas das margens do rio Pin- 
Na página seguinte [imagem 56], Córrego Oscar Americano, 2018. Óleo s/ cartão eucatex, $97 \mathrm{x}$ $33 \mathrm{~cm}$ heiros coincidem com as do córrego Pirajuçara mais pelo tratamento pictórico e pela técnica empregada do que pela sua conformação visual. Ainda que ambas as séries de paisagens integrem, geográfica e hidrograficamente, um mesmo território, a percepção da forma e a sensação geral de luz que temos no córrego Pirajuçara é muito distinta daquela das margens do rio Pinheiros, e as pinturas assim o atestam. É claro que as gravuras até agora apresentadas já exprimiam um caráter paisagístico singular, inexistente na paisagem do Pirajuçara, mas a questão é que, pela pintura, podemos ter um termo de comparação mais preciso, para atestar de que modo da experiência proporcionada pelas diferentes configurações espaciais de uma mesma bacia hidrográfica resultam paisagens muito diversas, com qualidades de forma, cor e luminosidade distintas.

O esquema compositivo frontal das vistas da margem não permite a identificação com o das "paisagens ideais", naturalistas ou românticas, assim como a atmosfera luminosa é muito distinta. De fato, nesse aspecto elas remetem mais aos panoramas das "paisagens dos fatos" e trazem um componente de registro, descritivo, uma vez que são constituídas por uma disposição articulada de um grande conjunto de informações visuais discretas, lado a lado, sem que se faça presente um princípio ordenador, como um rio em perspectiva ou uma iluminação que assuma um direcionamento específico. Pelo contrário, nessas paisagens panorâmicas, a luz é geralmente difusa e a composição tem como princípio a pura frontalidade horizontal, fazendo com que a diferenciação dos elementos se dê por relações visuais mais próximas, em que a lateralidade assume o protagonismo.

Nas margens do rio Pinheiros, não há como sugerir a profundidade espacial com o uso de diagonais que caminhem pelos sucessivos planos. A horizontalidade coloca uma limitação de meios que muda a ênfase do movimento visual, e, nessas paisagens, não há nada que guie o olho de um extremo a outro da paisagem, mas sugere-se ao olho um outro tipo de movimento: um traslado horizontal, com pequenas flutuações verticais aqui e ali, 


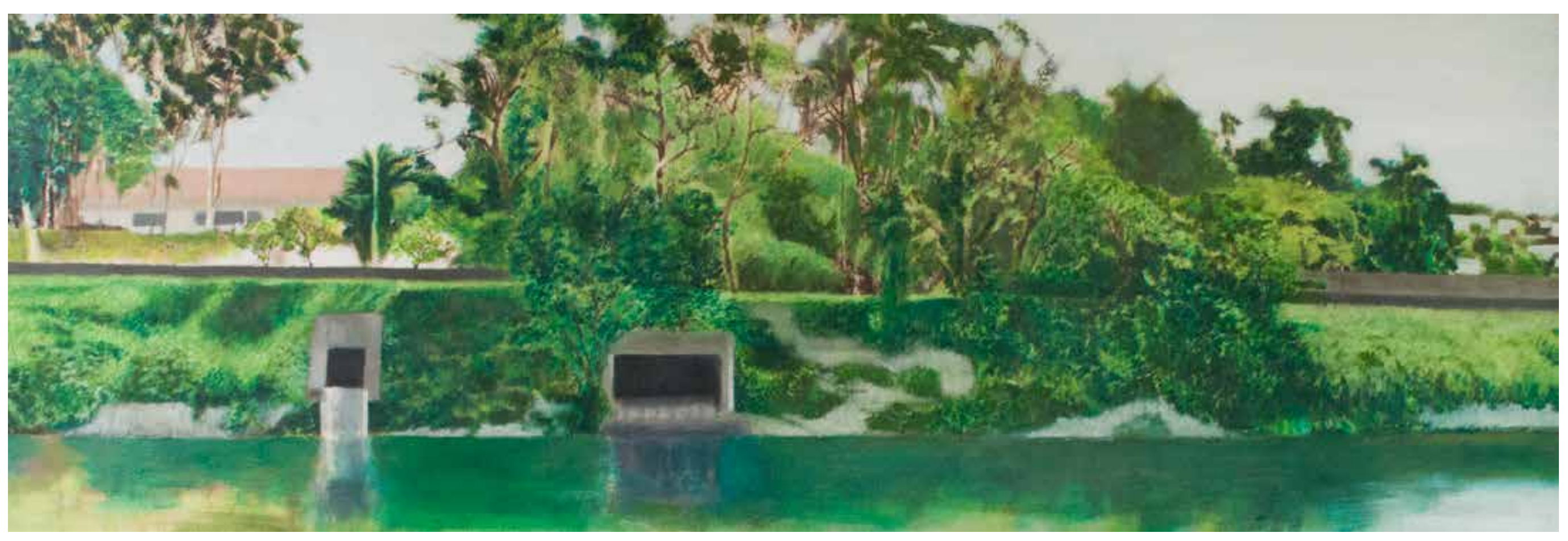


Na página seguinte [imagem 57], Margem sem reflexo (Jóquei Club). 2019. Óleo s/ tela montada em painel de madeira, $86 \times 14,5 \mathrm{~cm}$. o olho circula de um lado ao outro, visitando detalhes e pormenores sucessivamente dispostos lateralmente. A paisagem se mostra de um só ataque, está toda ali para se ver, e a visão está livre para deslocar-se sobre ela, sem hierarquias espaciais tão bem demarcadas. É em meio à planificação do plano pictórico que a diferenciação deve se dar, pela ordenação das faixas horizontais, ritmada pela distribuição vertical de pontos e linhas. É assim que a paisagem como vista frontal da margem do rio se traduz em exercício de ordenação e composição: a sutileza de cada relação entre formas, luzes e cores se individualiza mais em relação ao conjunto, pela relação desproporcional entre horizontalidade e verticalidade. O olho tem de se afastar muito de um pormenor para poder visitar outro que está na outra extremidade do quadro, fazendo com que a visão do primeiro se perca em função da visão do segundo. A paisagem é tão extensa, que não podemos contemplá-la como um todo sem perder a visão do detalhe, e isso pressupõe um movimento ocular de sucessivas aproximações e distanciamentos; ou se vê de perto, ou se vê de longe.

Do ponto de vista compositivo, há elementos centrais que engendram uma ordenação visual, como o jogo entre a massa mais clara de arbustos em forma de "couve-flor" e a torre levemente deslocada do centro que vemos na imagem acima.Essa paisagem não traz, contudo, qualquer desaguar de córrego ou boca de canal aparente, e somente uma reentrância do encontro entre a terra e a água marca o que poderia ser o equivalente a um “ponto central da imagem", logo abaixo da massa de arbustos citada anteriormente. Diferentemente da imagem anterior, nessa paisagem temos a horizontalidade o mais exacerbada possível, e os dois planos que antecedem o céu se dividem pela quase invisível presença do muro que divide o Jóquei Clube da via expressa: um primeiro, mais próximo, em que vemos a vegetação em fortes contrastes de luz e sombra; o segundo, mais distante, em que vemos, ao longe, numa região mais elevada, os morros que dão vista às casas do Morumbi.

Uma luminosidade quente, de sombras altamente contrastadas dá o tom à im- 


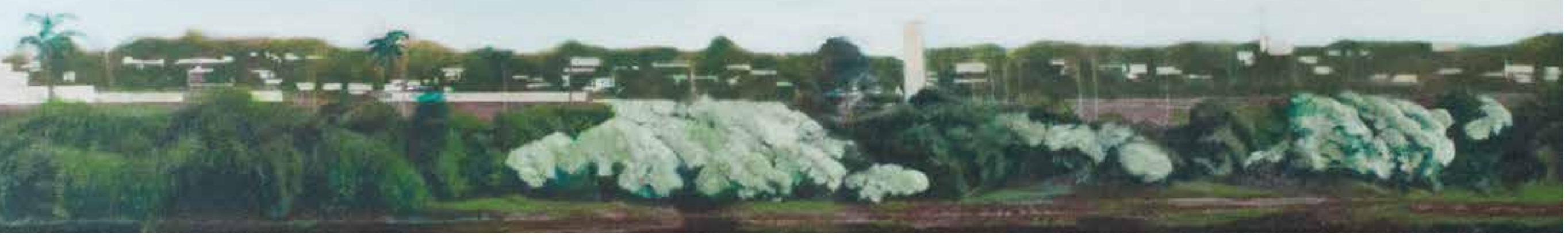


Na página seguinte [imagem 58], Margem Acidentada, 2019. Óleo s/tela montada em painel de madeira, $94 \times 20 \mathrm{~cm}$. agem, como se um sol baixo, de fim de tarde, incidisse sobre a vegetação e sobre as fachadas das casas nos morros ao fundo. Há uma atmosfera de imobilidade, uma calmaria estática, o vento não parece agitar sequer uma folha, e tal sensação se faz presente em quase todas as outras paisagens do rio Pinheiros: a de um tempo congelado, em que o ar, lento, quase repousa e as águas quase não correm, enquanto a velocidade da eletricidade e dos automóveis flui em um uníssono ruidoso pouco perceptível visualmente. Tudo o que se vê desse movimento são símbolos - torres e fios; e um ou outro carro atrás da espessa massa arbórea que esconde a via expressa à margem oeste do rio.

A segunda imagem desta série traz uma nova conformação da horizontalidade da imagem anterior. Temos uma visão um pouco mais próxima da margem oposta, entre duas faixas de espessuras quase iguais de céu e de seu reflexo. A maior aproximação nos dá a ver mais pormenores, e a margem traz uma maior ocorrência de variações de cor, texturas, reentrâncias e saliências. Há um evidente tratamento paisagístico, em que se distribuem arbustos de tonalidades mais quentes e mais frias, e a incidência do sol, também de fim de tarde, produz sombras projetadas e focos de luz ainda mais contrastados que os da imagem anterior. A porção central do terreno da margem parece agitar-se em ondulações, e o foco central da imagem nos dá a ver uma boca torta de um canal de drenagem que integra a área de influência do córrego Oscar Americano, como se houvesse se deslocado junto com a topografia acidentada ao seu lado. Uma árvore luminosa adorna essa boca circular, da qual não escoa água alguma. A boca, ainda que relativamente pequena, parece querer sugar todo o ambiente para si; como se a paisagem possuísse um olho ciclópico feroz, que mira reciprocamente em nossa direção. É interessante notar como esta imagem remete à terceira xilogravura exposta no primeiro capítulo (imagem $\mathrm{x}$, pagina $\mathrm{x}$ ), em que temos um ponto central para onde toda a horizontalidade parece confluir, um buraco negro que, lentamente, suga tudo ao seu redor. 


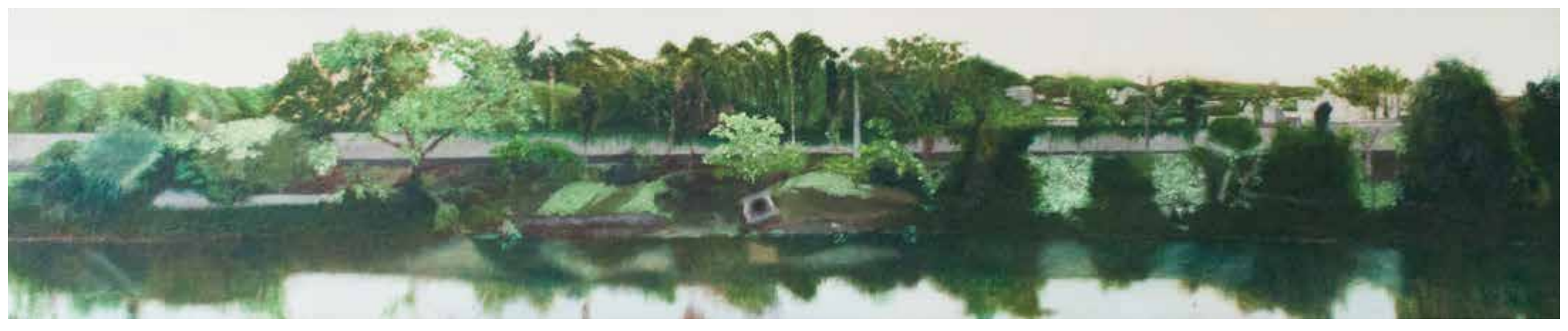


Assim como a boca de córrego divide a paisagem em um eixo central, a luz do sol incide mais sobre a metade esquerda do que sobre a metade direita da imagem, de modo que parece quase inverossímil. Temos assim um lado claro e um lado escuro da paisagem, e esse jogo de luz parece se repetir nestas três últimas imagens, de modo que a luz sempre incide da direita para a esquerda: tal direcionamento da luz coincide com o sentido de movimento visual que sugerem estas paisagens, sempre da esquerda para a direita, no sentido de leitura. Inclusive, se há nelas uma "perspectiva” geométrica, ela ocorre sempre, ainda que sutilmente, na porção direita da imagem, e é sempre este o lado mais distante do observador, em que a faixa que representa a margem do rio se torna progressivamente mais estreita. Nesse aspecto, as paisagens traem a frontalidade absoluta, evitando a neutralidade de um total equilíbrio compositivo horizontal: colocando algum sentido lateral de movimento, as paisagens ganham alguma vida, e se afastam um pouco do aspecto de elevação arquitetônica.

Na sua condição de vistas frontais, em sua rígida ordenação tripartida, não há um rio que perfure o quadro plano a plano em direção ao horizonte; tudo é ortogonal ao vetor do olhar, e só resta ao rio levar o olho de uma ponta à outra. Se o sentido desse movimento visual é sempre da esquerda para a direita, isso se deve, talvez, à cultura visual que nos ensina a ler imagens como lemos o texto. Se do lado esquerdo temos, no plano de fundo, somente árvores banhadas pelo sol, à direita temos uma porção mais distante de morros, menos iluminada, em que entrevemos casas em meios às árvores. É como se algo nestas paisagens do rio Pinheiros, especificamente em sua margem Oeste, retratada frontalmente em todas as pinturas desta série, nos demonstrasse sempre a proximidade à esquerda e a distância à direita. É como se a representação do rio como paisagem nos indicasse um sentido geográfico de seu movimento, ou melhor, como se a paisagem nos atraísse em direção ao Sul (lado esquerdo), colocando o Norte (lado direito) à distância. De fato, é em 
direção ao Sul que o sentido cronológico e espacial do deslocamento proposto pela série de vistas se dá, uma vez que a porção que segue em direção ao Norte ainda não dispõe de ciclovia que só chega à Ponte do Jaguaré. Ao Norte, o rio se encaminha para desaguar no Tietê; ao Sul, estão a Usina Elevatória de Traição e a Represa Billings.

Mas o que é mais importante lembrar é que as águas do rio Pinheiros, de fato, não correm nem para cá, nem para lá, e sua condição de rio morto nos coloca diante de um impasse: temos que procurar seu direcionamento, que parece oscilar a cada dia. Talvez não sejam as águas do rio Pinheiros que nos indiquem seu direcionamento, mas, sim, as suas margens. É à direção Sul que nossa pesquisa parece apontar, não por acaso coincidindo com a extensão da ciclovia que o acompanha. Ao sul também aponta a expressão mais evidente da transformação de sua paisagem, no sentido do desenvolvimento da infra-estrutura urbana e centralidade comercial e econômica que se instala à sua margem Leste, como pudemos ver nas últimas três gravuras em metal [imagens 19,54 e 55, pp. 79, 179 e 181].

A quarta imagem [59] que compõe esta série de pinturas é, talvez, a mais singular entre todas elas, uma vez que temos nela uma expressão da gênese da atual paisagem do rio Pinheiros. Esta imagem poderia pertencer a um outro tempo, anterior ao recente tratamento paisagístico dado ao rio, remetendo à "paisagem em obras" que o caracterizou durante o processo de sua canalização. A vegetação que cobria as imagens anteriores está completamente ausente, e a terra sobre o concreto não mais está parcialmente exposta, sob as falhas da cobertura vegetal, mas ocupa plenamente a margem. Temos então uma margem como que despida, como se sua pele estivesse esfolada, em carne viva, coberta por secreções, cascas e pus ressequido. Sobre ela as retro-escavadeiras estendem e retraem seus braços como parasitas que vasculham a epiderme em busca de alimento. E a barcaça coletora de lixo à esquerda, utilizada em uma eterna tarefa de desassoreamento, repousa à 
Na página seguinte [imagem 59], Margem em obras, 2019. Óleo s/ tela montada em painel de madeira, $94 \times 20 \mathrm{~cm}$. margem, como se encalhada, semi afundada no leito raso deste rio.

Outras barcaças, de cores mais vivas, operam à direita, trazendo a este setor da imagem alguma animação. Mas impera uma impressão de morosidade, como se tais objetos flutuantes, assim como os pequenos tratores sobre a margem, fossem animais antigos, como dinossauros, vagando quase sem sair do lugar, tomando sol e alimentando-se de restos de rio. Ao centro, duas fendas no solo parcialmente erodido sobre a margem criam, com o reflexo na água, uma forma que remete ao signo de um esqueleto de peixe, nadando da direita para a esquerda, contribuindo a uma certa "animalidade paleontológica" simbólica presente nessa paisagem.

A composição, assim como nas imagens anteriores,impõe uma ordem geométrica rígida sob aparente organicidade: vemos uma margem mais distante, implicando em uma sensação de amplidão inédita até então; a faixa central da margem é estreita, e a imagem se estrutura em três faixas de larguras semelhantes, em que a linha horizontal que separa o reflexo na água da "verdadeira" margem, divide o plano da imagem quase exatamente ao meio. Como nas paisagens anteriores, a maior massa de volumes e concentração de sombras está centralizada, e, ainda que este "centro" se espalhe horizontalmente, ele não chega às extremidades da esquerda e da direita. Na faixa horizontal mediana, a margem e seu reflexo, vemos três elementos visuais em primeiro plano (a barcaça à esquerda, as fenda escuras no solo e as barcaças à direita, respectivamente) que estruturam visualmente o ritmo de um movimento, espaçados lateralmente em distâncias equivalentes.

Trata-se de uma paisagem de aspecto menos sombrio, de uma luminosidade mais direta e centralizada, de um sol de meio dia. Apesar de o azul do reflexo na água sugerir um céu límpido, não há uma atmosfera luminosa de alto contraste, como se houvessem nuvens bloqueando parcialmente a luz do sol, o que é, de fato, uma característica da luz em São Paulo: mesmo em dias ensolarados, de céu azul, é difícil que, ao cair da tarde, algumas 


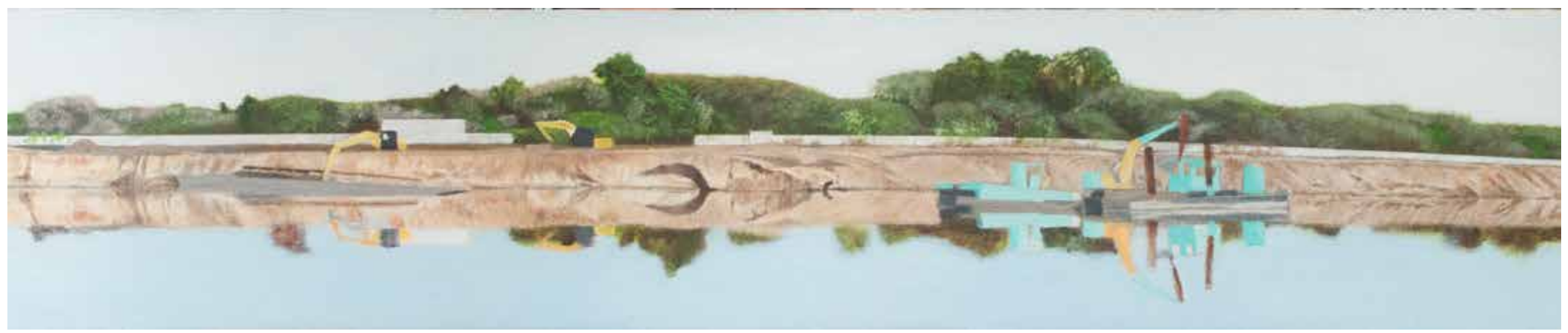


nuvens não apareçam para modular a insolação, trazendo uma constante alternância entre sombra e luz direta. Se há algo de uma luz característica de São Paulo que se mostra nessas imagensé justamente essa variabilidade, a inconstância de iluminação, em que nuvens sempre em movimento tingem de branco um céu que raramente está plenamente limpo e que, salvo em alguns dias de outono e inverno, nunca passa o dia todo azul. Quanto mais próximo da linha do horizonte, mais o céu se torna esbranquiçado e nebuloso, e pode-se afirmar, sem grandes ressalvas, que a característica geral da percepção que se tem do céu em São Paulo é mais a de uma luz pálida e ofuscante do que a de um céu plenamente azul. Nesta última imagem, contudo, temos a esperança de um céu azul de outono, que não se vê em nenhuma outra das pinturas. Trata-se de uma pintura inacabada, e o fundo vermelho aparente sugere, além da complementaridade de cor com o verde da vegetação, uma atmosfera de calor solar que coincide com o azul do céu.

Em relação às anteriores, esta imagem não explora tão radicalmente a sensação de horizontalidade, e temos um olhar mais próximo da margem oposta, mas ainda frontal. No entanto, tal frontalidade é quebrada pela presença da ponte em perspectiva, que realiza a transposição de uma linha de tensão de uma margem à outra, próxima à Ponte da Cidade Universitária. Esta imagem retoma o olhar que viu as primeiras gravuras, em que um evento de transposição interrompe a horizontalidade da paisagem, colocando-nos um sentido de profundidade em direção a um horizonte que não se vê. Como na última gravura apresentada, a Ponte Estaiada [imagem 55 , p. 181], esta imagem traz a visão da margem sobre a qual o observador se situa, em primeiro plano, o que confere uma maior sensação de proximidade, inserindo-o no espaço, situando-o de modo mais definido em relação à margem que se vê do outro lado. De certa forma, a visão da margem imediata confere às paisagens uma maior intimidade corpórea entre o observador e o mundo visto, que não mais se perde na margem oposta, como nas imagens anteriores, mas guarda um 


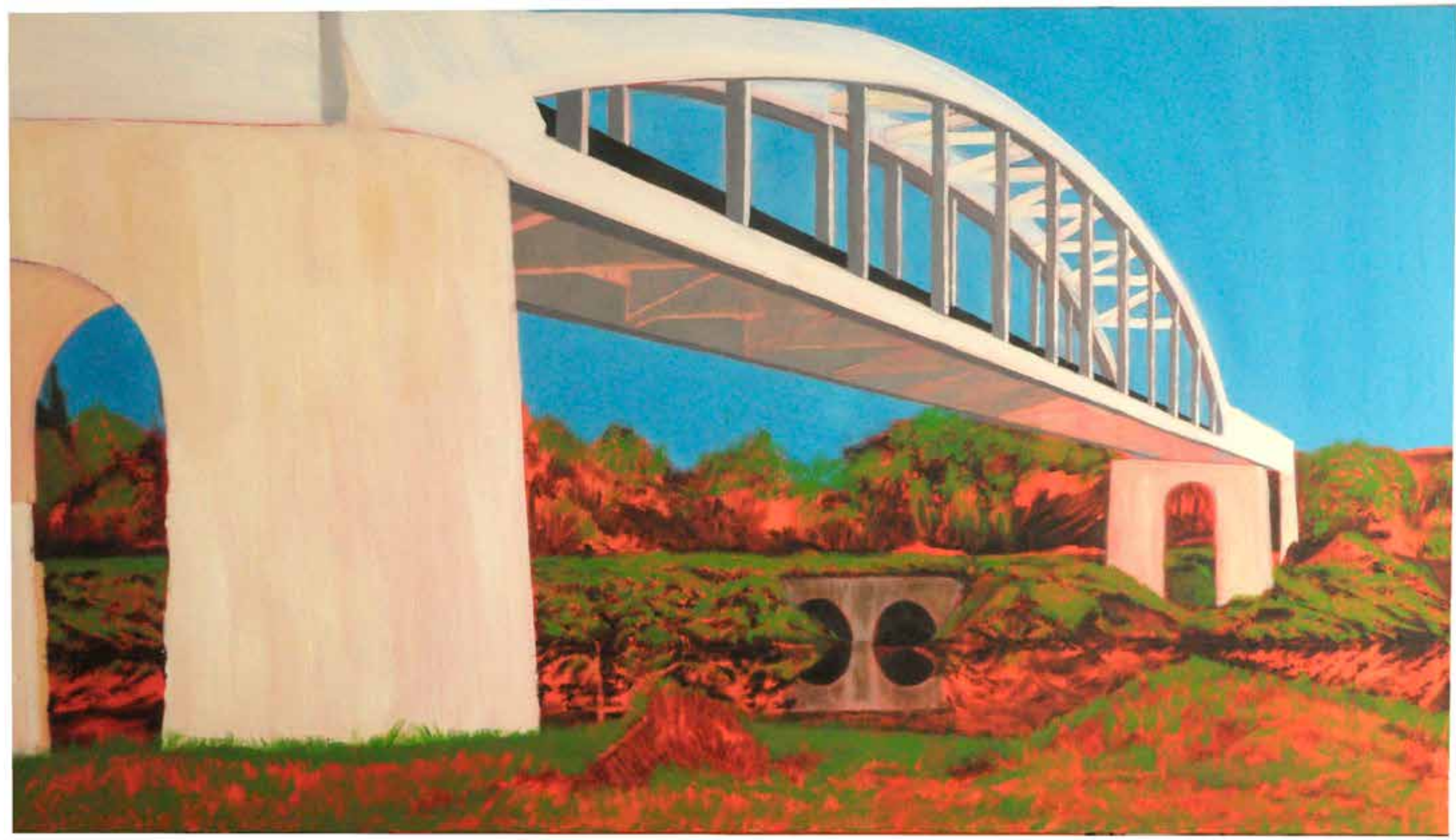


referencial melhor definido de onde o espectador se encontra.

Novamente, o sentido de movimento da paisagem é aquele que leva o olho da esquerda à direita, e a imagem tem seu centro nas duas bocas de escoamento em arco que trazem a água da área de contribuição dos córregos Pirajuçara e Oscar Americano. Como elemento compositivo, reitera-se a forma em arco das bocas de esgoto também nos pilares, à esquerda e à direita, que sustentam a ponte que transpõe a linha elétrica, assim como nos arcos sobre a ponte, que encerram a porção superior da imagem. Esta ponte, no entanto, não se parece tanto com as pontes das primeiras gravuras em metal do capítulo 2, mas tem um estatuto diverso. Ela simboliza uma das componentes mais importantes e presentes em toda a paisagem das margens do rio Pinheiros, que é a fiação elétrica, que vemos constantemente na série, com suas torres e fios percorrendo a margem do rio. A transmissão da eletricidade é, talvez, uma das principais razões práticas de ser dessas paisagens; ela ocupa um espaço privilegiado e segregado em relação à infra-estrutura de transporte, e esta ponte é uma das suas expressões mais significativas. Na coleção de corpos fossilizados, esqueletos e carcaças, os "seres" ou "personagens" que habitam a paisagem do rio, ela aparece como um animal quadrúpede monstruoso, com sua ossatura exposta, atravessando lentamente o rio.

Talvez esta imagem já inaugure um outro olhar, que não mais se dirige tanto à paisagem em sua amplidão horizontal e à sucessão de planos de cidade que se amontoam em perfis de elevação, como nas últimas pinturas apresentadas. Parece surgir, especialmente nestas duas últimas pinturas, um interesse em retratar, com maior proximidade, os "seres" que habitam esta paisagem, e assim afasta-se um pouco da ambição geográfica e do registro dos fatos, que caracteriza as imagens mais panorâmicas e horizontais. A presença e o protagonismo de tais "figuras" monumentais do rio Pinheiros traz uma nova dramaticidade, uma outra narratividade à paisagem, que de algum modo se sobrepõe à percepção 
de geograficidade e à descrição do espaço.

Entretanto, o que podemos constatar como característica geral desta última série de imagens se define mais por um certo formalismo do que pelo conteúdo lírico ou temático por meio de seus "motivos" ou "figuras". Há uma constante busca de articulação compositiva de elementos verticais em meio à absoluta horizontalidade, e a ordenação ritmada de balizas visuais que criam focos e blocos de relações plásticas em meio à frontalidade constante das paisagens. A sensação geral que se apreende é a de uma paisagem em repouso, quase parada no tempo, em que predomina a solidez e a imobilidade austera de todas as coisas, como se existissem na abstração de um projeto arquitetônico. A mobilidade, quando ocorre, é apartada da paisagem, e está nas singelas silhuetas dos carros, escondidas sob as massas de vegetação e por entre muros de concreto. Assim, temos uma representação da paisagem que se pode associar à dos jardins intramuros das paisagens simbólicas: talvez o sentido de ordenação, quase decorativa, a que se subsume toda a vegetação disposta lateralmente, com suas variações de cor, luz e textura, traga algo de um olhar paisagístico que encerra a paisagem dentro de um muro, contrapondo-se ao mundo que se vê ao longe, atrás dele. Esta série de imagens, mais do que as gravuras anteriores, mostram-nos a paisagem do rio Pinheiros em sua artificialidade de jardim, como espaço confinado e segregado da cidade.

A expressão dessa artificialidade se mostra em uma certa "beleza natural” em que vemos o misto de ordenação planejada com precariedade e decadência. Pela pintura, as coisas e fatos da paisagem se revestem de gravidade e de uma aparente imutabilidade, traduzindo, talvez, um desejo (in)consciente de investir de permanência aquilo que é precário e que vive sob a condição de marginalidade. Do ponto de vista formal, isso implica em uma vontade de ordenação e disposição espacial das coisas na paisagem de modo que se crie um conjunto harmônico enquanto desenho. Nesse sentido, esta última série se as- 
socia, de certo modo, à paisagem da arte moderna, no que ela compreende a representação pictórica do mundo visto como uma harmonia paralela ao visível, e não a sua imitação naturalista ou realista. Por mais que tais imagens possam conter algo de um naturalismo realista, o olhar que as representa como imagem se ocupa de uma escansão métrica da margem do rio, articulando o plano de representação como um sistema de equivalências visuais, que tende à abstração da entidade "natural" dos fatos paisagísticos e de sua articulação espacial. Talvez a paisagem da margem do rio Pinheiros, por sua própria característica de artificialidade, não nos possa comunicar mais do que uma abstração da natureza das margens de rio.

É por esta razão que, seguindo o desenvolvimento da história da paisagem na arte baseado em Kenneth Clark, nos dedicaremos à análise da atitude paisagística que o autor intitula de "O Regresso à Ordem”, uma expressão da pintura de paisagem que, às vésperas do modernismo, culminou em um desinteresse pela representação da paisagem visível. Esta teria sido subsumida a uma linguagem puramente abstrata e geométrica, em que a função estética da referência à natureza exterior se submete a um universo de natureza subjetiva e intelectual. Sob esta perspectiva, veremos como a representação paisagística retorna à baila após o contexto vanguardista, ainda sob os termos do binômio "figuração x abstração", cuja superação é expressa no exemplo da obra do pintor norte-americano Richard Diebenkorn. 
4.1

\section{Rumo à abstração: a paisagem moderna como sintaxe da per- cepção visual}

"Como o pintor ou o poeta nominaria outro evento que seu enlace com o mundo? Ora, a austeridade, a sucessão fantasmagórica das aparências e formas geométricas [...] exalam embora algum relento de vida, ainda que tímida ou desesperada." (MERLEAU-PONTY, 1980., p. 154)

A passagem proferida por Merleau-Ponty em $A$ linguagem indireta $e$ as vozes do silêncio é especialmente significativa para que iniciemos esta etapa de nossa reflexão. Discutindo a análise de Malraux sobre a crítica à objetividade na arte moderna, MerleauPonty nos aponta que o escritor vê na pintura moderna um "retorno ao sujeito", em oposição à exterioridade que dominava a pintura clássica, que buscava representar de modo "mimético" a experiência visual. O ensaio de Merleau-Ponty, no entanto, se ocupa de refletir sobre a linguagem, e o exemplo da pintura, ao qual o filósofo costumava recorrer para desenvolver sua fenomenologia, serve a seu projeto. À luz de sua reflexão sobre a linguagem, o filósofo, apoiado no pensamento de Malraux, demonstra como a concepção moderna, mais "subjetiva", da pintura já estava presente na tradição da pintura, e que a arte moderna apenas passou a teorizar sobre tal aspecto. Como nos diz o filósofo, os pintores clássicos,

"No instante mesmo em que, olhos fixos sobre o mundo, acreditavam perguntar-lhe pelo segredo de uma representação suficiente, exerciam sem o saber esta metamorfose de que a pintura mais tarde se tornou consciente. Não se pode definir a pintura clássica pela representação da natureza ou pela referência aos "sentidos", nem, portanto, a pintura moderna pela referência ao subjetivo. A percepção dos clássicos já estava imbuída de sua cultura e a nossa pode ainda enformar a percepção do visível. Não se deve abandonar o mundo visível aos preceitos clássicos, nem limitar a pintura moderna ao reduto do indivíduo. Não se trata de escolher entre o mundo e a arte, entre os "sentidos" e a pintura absoluta: imbricam-se mutuamente." (1980, p. 148)

A dinâmica acelerada das transformações na arte do final do século XIX é a chave 
1. A respeito dessa ideia, é significativo o comentário tecido por Maurice Merleau-Ponty, a partir de Malraux em La Création Estétique, em que se critica a atitude moralizante de alguns pintores modernos diante de uma verdade e uma pureza no emprego dos meios da pintura: “[...] Malraux nota com muita acuidade pintores que modernos que "conquanto não falassem nunca de verdade, diante da obra de adversários falavam todos de impostura". Rejeitam uma verdade que seja correspondência da pintura ao mundo. Aceitariam a ideia de uma verdade que expressasse a coesão da pintura consigo mesma pela imanência de um princípio único que conferiria a cada meio de expressão um determinado valor de emprego." (MERLEAU-PONTY, 1980, p.154) para que possamos buscar entender aquilo que virá a ser o imaginário contemporâneo da paisagem. A derrocada da visão naturalista e a curta vida do impressionismo são episódios especialmente significativos para vislumbrarmos as causas do desaparecimento da paisagem na arte das vanguardas do século XX. A paisagem voltará a ser um assunto artisticamente relevante somente após o fim das vanguardas, já no que vem a ser chamado de “arte contemporânea”. Isso não quer dizer que todos os grandes pintores tenham deixado de produzir paisagens, mas que diante da crítica e do mercado elas já não gozavam do mesmo prestígio e ênfase que as alçara à plena autonomia como gênero no século anterior.

Para Kenneth Clark, é, em grande medida, devido à especialização das atividades humanas que a "ideia das sensações estéticas puras" veio a ditar novos caminhos para a pintura. Esta ideia, segundo o historiador,

"Constitui claramente parte de um movimento geral, que se manifestou em cada setor da vida, desde a filosofia até aos sistemas de arquivo, durante os últimos cinquenta anos; pode designar-se por doutrina das essências ou por diferenciação de função."(CLARK, 1961, p.172)

Caminha junto a essa ideia uma reação artística ao distanciamento entre ciência e arte, consolidado no pensamento moderno, e o desejo de conferir às artes visuais uma linguagem estética "pura”, com uma sintaxe precisa, mensurável tal como a da música ou da arquitetura, em que a pintura, ao desvincular-se de uma referência ao mundo visto como tal, eleva-se a um grau superior de verdade ${ }^{1}$. Por meio deste modo de ver a construção da imagem, forma e cor perderiam o referencial mimético a uma coisa exterior para que fossem entidades visuais cuja beleza se faz por si mesma, assim como seus possíveis significados não se limitam a esse referencial natural. Clark aponta para uma origem platônica nessa ideia de pureza:"A dialética da arte abstrata é de fato inteiramente clara e lógica, muito mais do que qualquer explicação da pintura tradicional, tendo até uma origem mui- 
to respeitável." ( 1961, p.173) O autor refere-se ao Philebus, quando Platão relata a seguinte fala de Sócrates:

“Tentarei falar da beleza das formas, pelas quais não significo, como a maior parte das pessoas suporia, as formas das figuras vivas ou as suas imitações na pintura, mas sim as linhas retas e curvas e as formas por elas constituídas, pelo trono, régua ou esquadro. Não são belas por qualquer razão ou propósito particular, como as demais coisas, mas são eternamente e pela sua própria natureza, belas e dão prazer por si mesmas; e neste sentido as cores podem provocar um prazer semelhante." (1961, p. 173)

Esta fala do filósofo encampava conceitualmente ativistas e partidários do abstracionismo, e à época em que Paisagem na Arte foi escrito, a força deste enunciado era respaldada de modo convicto pela produção de artes visuais em geral. Apesar de Platão se referir à geometria, seu ideal da bela forma se desdobra para além das formas geométricas, e sua visão toca em outros pontos cruciais da representação e da pintura, que correspondem às necessidades de ruptura com a tradição da pintura naturalista. A "emancipação" da cor, da linha e das superfícies como entidades pictóricas, que nos informam uma visualidade que existe somente segundo elas próprias e suas relações, já era parte de um processo de transformação, e mesmo o impressionismo, com sua fidelidade à beleza natural, já realizava a mudança no sentido desse ideal autônomo da forma na arte.

Se a tese de que "a beleza eterna é a que pode ser medida ou aferida analiticamente por outros termos" (1961, p. 173), como bem resume Clark, fosse verdadeira, o sentido do espírito artístico teria realizado parte das utopias futuristas e do desenho modernista; a arte se tornaria, no limite, uma só linguagem, cujas infinitas variantes seriam a manifestação de uma mesma ideia. Seus termos de aferição e seu vocabulário seriam intercambiáveis entre os diferentes meios, que seriam, cada qual, uma forma especializada de uma mesma arte, ou seja, cada uma das formas de arte se ocuparia do atributo que melhor se 
2. Cf. GREENBERG, C. Modernist Painting. In: FRASCINA, F.; HARRISON, C. (Eds.). Modern Art and Modernism: A Critical Anthology. Thousand Oaks: SAGE Publications, 1982.; GREENBERG, C. Towards a Newer Laocoön. In: FRASCINA, F. (Ed.). Pollock and After: The Critical Debate. London: Routledge, 1985. adéqua ao seu meio material e à sua expressão, cada qual em seu posto: pintura é pintura; escultura é escultura; arquitetura é arquitetura, e assim por diante. De uma determinada qualidade escultórica, poderíamos apreender somente o essencial, a ideia, e traduzi-la em seus equivalentes termos musicais; a uma melodia, corresponderia uma forma exata, que poderia ser lida como uma partitura. A estética greenberguiana ${ }^{2}$ é conhecida por incorrer por esses caminhos demasiado rígidos em que opera a especificidade de cada meio artístico, e não é nada estranho que fosse ele um dos grandes entusiastas do expressionismo abstrato nesta mesma época em que escreveu Kenneth Clark. Como já dissemos, uma geração de críticos de arte como o americano Clement Greenberg, e Mario Pedrosa no Brasil, que ajudaram a fundar a reflexão contemporânea sobre a arte, foi formada em meio à explosão das vanguardas da arte moderna e da guerra total na primeira metade do século XX. A abstração, para eles, mais do que um modo da visualidade, se constitui em uma causa a favor do progresso e da liberdade.

Contudo, de volta ao ponto da narrativa em que nos situávamos, temos como dado que este caminho das paisagens em direção à abstração se deu, em parte, pelo expressionismo, que já em românticos como Turner viu novas possibilidades de cor, luz e forma, e em outra parte por um olhar singular que divergia do impressionismo, o olhar de artistas como Seurat e Cézanne. Ambos os artistas, como nos mostra Clark, compartilhavam uma busca pela ordem e pelo rigor na construção da visualidade. Contudo, o olhar impressionista era alheio a esta ordem, uma vez que “[...] como todas as genuínas formas de arte, criou a sua própria ordem, através da consistência da visão e da contextura. Era a unidade sensacional do olhar ou do instantâneo." (1961, p.143) A ordem e os esquemas compositivos aperfeiçoados por Poussin nunca serão capazes de explicar pinturas dos impressionistas, “[...] que os deviam ter considerado incompatíveis com a sua técnica. Em conseqüência não podiam realizar, nem a escala, nem o tom de permanência dos seus maiores predecessores." (1961, p.143) 
É também uma crítica ao "tom de permanência”, essa solidez em profundidade de que fala Clark, que se refere a reação abstracionista que preza pela planaridade como qualidade específica do meio pictórico. O impressionismo já é, portanto, um passo em direção a essa planaridade, desvencilhando-se da profundidade ilusória da pintura tradicional. Georges Seurat, por seu lado, era”[...]um grande mestre de leis matemáticas da harmonia, por meio das quais os maiores arquitetos do passado, e alguns dos maiores pintores, asseguraram seus resultados."(1961, p.145) E tão grande era a sua ambição de criar obras com a grandeza e solidez atemporal da pintura renascentista, que buscava fazê-lo por meio de um desenvolvimento científico das luzes e cores vibrantes do impressionismo. $\mathrm{O}$ método pontilhista, pelo qual o pintor é comumente conhecido, é só uma das características de sua pintura. O exemplo do Banho, segundo Paul Signac, nos mostra:

Ao lado [imagem 61], Georges Seurat, Um Banho em Asniéres, 1884, óleo s/ tela, 201 x 300 cm. National Gallery, Londres.

https://pt.wikipedia.org/wiki/Um_banho_em_ Asni\%C3\%A8res

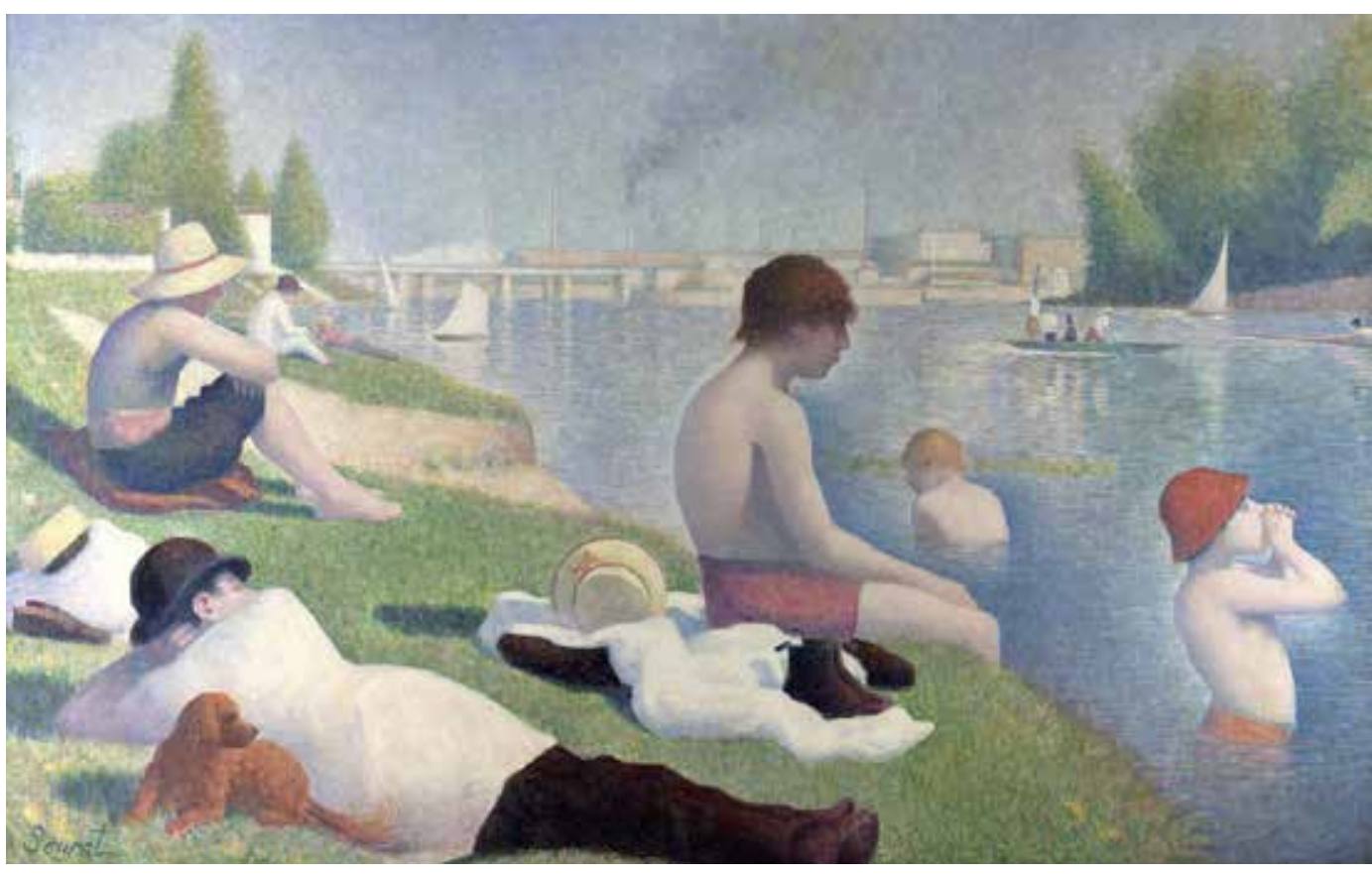



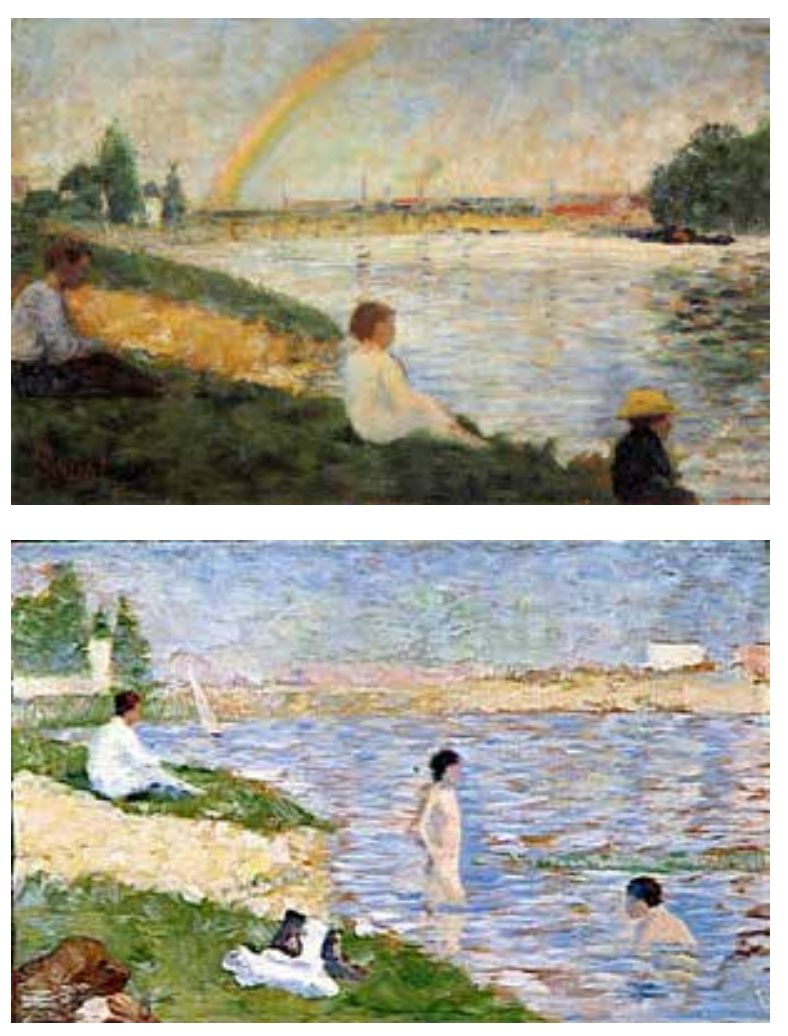

No topo da página [imagem 62], Georges Seurat, $O$ arco-iris: Estudo para 'Um banho em Asniéres',1883. Óleo s/ madeira $15.5 \times 24.5 \mathrm{~cm}$. National Gallery, Londres

Fonte:https://www.nationalgallery.org.uk/paintings/ georges-seurat-the-rainbow-study-for-bathers-at-asnieres Na sequência [imagem 63], Georges Seurat, Estudo para 'Umbanho em Asniéres', 1883 . Óleos/madeira $15 \times 25 \mathrm{~cm}$. Musée d Orsay, Paris.

htrps://ngagovau/Exhibition/MASTERPIECESfromPARIS/Default.fm?IRN=191249\&BioArtistIRN=16097\&MnuID $=$ SRCH\&ArtistRN $=16097 \&$ ViewID $=2$ “a compreensão das leis do contraste, a separação metódica dos elementos, luz, sombra, cor local e a interação das cores, o seu equilíbrio e proporção adequados, que conferem a esta tela a sua perfeita harmonia". (1961, p.147)

As figuras de Seurat são dotadas de um "ar de permanência" digno das figuras da arte acadêmica, e, segundo Clark, esta pintura demonstra um profundo conhecimento dos afrescos italianos do século XV, em especial de Piero della Francesca. Interessa-nos, sobretudo, destacar em Seurat o misto de uma intenção naturalista com a da montagem compositiva de ordem intelectual, que confere à paisagem certa semelhança às nossas pinturas do rio Pinheiros. Nelas, há também um tom de permanência e solidez que, por sua vez, não abdica totalmente da visão natural e do registro da sensação. Trata-se de pinturas em que a composição é construída com o desenho de observação e auxiliada pela montagem de fotografias. E é nesse sentido que buscamos compreender o que vemos, a exemplo da obra de Seurat: uma paisagem que, a um só tempo, diz respeito à sensação visual da luz viva e instantânea, e da corporeidade profunda do mundo visto. Não há na obra de Seurat uma justificativa técnica e poética para que a paisagem não possa ser representada tanto pela sua fugacidade quanto pela sua duração; sensação e intelecto, exterioridade e interioridade, objetividade e subjetividade estão unidas na paisagem, e não há razão para que não possam ser simultaneamente descritas e representadas. Os muitos estudos realizados por Seurat para esta obra nos mostram uma visão mais ágil, uma fatura mais veloz que seria digna de uma pintura alla prima impressionista.

O que Clark lamenta, corroborado por outros críticos, é que a pintura final de Seurat perde a tonalidade fresca de seus estudos feitos de observação do natural, o que é compreensível. E isso, no caso de Seurat, se agrava pelo seu método científico de aplicar a cor pela complementaridade, o que confere uma coloração pouco natural à sua pintura de ateliê. 
"É uma procura inteiramente intelectual da cor, baseada não na percepção, mas na convicção de que os efeitos de cor podem ser medidos cientificamente. O críticos de arte, desde os períodos clássicos, afirmaram sempre que a cor é o elemento sensível e emocional da pintura; pode-se perguntar se tentativa de Seurat não iria contra uma lei fundamental da arte. teria respondido com a afirmação de Sutter de que "as leis da harmonia estética na cor podem ser ensinadas como as da harmonia musical"; mas, para mim, as suas concepções científicas produziram o mesmo efeito que as teorias harmônicas de Schönberg, onde um vasto numero de instrumentos apenas conseguem produzir um barulho indeterminado, sem claridade ou ressonância." (1961, p.151)

Sua morte precoce em 1891, aos 35 anos, limitou o amadurecimento deste artista precoce. O rigor construtivo e o pontilhismo de Seurat acabaram por tornar sua pintura dotada de um certo academicismo e de uma cor neutralizada, que, diante das conquistas posteriores da pintura, o tornaram coadjuvante em um "pós-impressionismo" protagonizado em grande medida por Cézanne.

Uma das características principais que colocam Cézanne como um revolucionário no olhar para a paisagem residiria na sua limitada habilidade estilística na imitação da tradição pictórica e na sua dependência incondicional do modelo, uma vez que era incapaz de pintar "de memória". Tais características teriam fundamentado a sua pintura no primado da percepção, que iria muito além da sensação de luz naturalista dos impressionistas. A profundidade em Cézanne era construída por meio da relação entre sólidos planos, que orientavam segundo a sua percepção a relação entre o plano pictórico e suas formas. A concisa ordenação do espaço em Cézanne nada tem de tradicional ou erudita, sendo realizada por meio de uma geometria intuitiva, que nem por isso deixa de ser rigorosa. Em segundo lugar, como nos afirma Clark:

"Prefigura também uma das principais características que separam Cézanne dos impressionistas: a frontalidade do ataque. As poderosas horizontais que ocorrem 
paralelamente ao plano do quadro e apóiam as massas simplificadas, produzem um assalto imediato à vista, diferindo tanto dos cuidadosamente elaborados "eixos ortogonais" da paisagem barroca como da composição equilibrada clássica." (1961, pp. 153-54)

Esta passagem interessa particularmente à nossa pesquisa, na medida em que a frontalidade é também uma das características principais das paisagens das margens do rio Pinheiros. Para além do tratamento de sombras e volumes em camadas, que confere maior solidez à paisagem, temos em nossas imagens uma profundidade constituída pelo jogo de planos horizontais cuja separação é nitidamente demarcada. Os elementos construídos mistos à ênfase na linearidade das formas do relevo também contribuem para que as paisagens do rio Pinheiros adquiram esta ordenação "arquitetural", que as aproxima das paisagens ideais de Poussin e, de alguma forma, dos precursores da abstração.

O esquema composicional clássico ensinado nas escolas, nos informa Clark, era aquele em que uma estrada ou um rio caminham em diagonal em direção à profundidade. A frontalidade, por outro lado, ao invés de nos fazer percorrer um caminho até a paisagem, já nos dá diretamente a visão do motivo, o que implica numa menor margem para a construção da profundidade e do movimento visual. Desse modo, a profundidade da paisagem tem de ser expressa com maior ênfase nas relações de valor cromático, tonal ou de textura, entre os planos, implicando numa necessária ênfase na estruturação ou ordenação visual do espaço pictórico.

Os primeiros anos de Cézanne como pintor tornaram-no um disciplinado estudioso da tradição e da observação, em suas naturezas-mortas, e há relativamente poucas pinturas de paisagem desta época. Clark inclusive conjectura uma possível relação entre o estudo da natureza-morta e a singular frontalidade e solidez repousante dos objetos nas suas paisagens, uma vez que a natureza-morta é propícia à ordenação espacial de objetos, 
de uma espacialidade independente dos artifícios da perspectiva, além do fato de que as naturezas-mortas, “[...] livres de qualquer interesse dramático ou literário, obrigam o pintor a preocupar-se apenas com as suas qualidades picturais." (1969, p. 154)

Sendo assim, Cézanne tornou-se um desenhista de observação adepto de uma disciplina e de um rigor obsessivos, cuja percepção e poética visual escapava aos modelos de realismo ou naturalismo precedentes. Sua filiação ao grupo impressionista lhe rendeu recursos de linguagem e uma cultura pictórica, mas fica patente em suas obras deste período que sua investigação visual tirava do impressionismo apenas a pincelada interrompida e a vibrante fragmentação tonal da cor. Com sua autodisciplina e estudo autônomo, encaminhou-se para um amadurecimento como pintor que o afasta muito das sensações de luz impressionistas, pois sua intenção era a realização plena das formas, a densidade e a profundidade das coisas, segundo a latência de cor que traz à tona a experiência atual do visível. Nem o impressionismo, nem a tradição sustentariam totalmente a sua poética, e, como nos diz Clark:

"Reconhecera não poder exprimir esta concepção de mundo por meio de imagens, semi-inventadas, semi-recordadas dos antigos mestres; apenas o poderia fazer realizando com inteira verdade as sensações visuais nele despertadas pelos objetos naturais. A técnica dos seus amigos, os impressionistas, oferecia-lhe um meio para registrar cada tonalidade da sensação visual, mas durante um certo tempo Cézanne considerou encontrarem-se eles demasiado preocupados com a superfície das coisas."(1961, p.154-55)

Observemos então a obra a seguir para vermos a esse ponto a frontalidade não ortodoxa de um Cézanne em pleno desenvolvimento, após ter sido discípulo de Pissaro, mas já independente da fatura impressionista. 


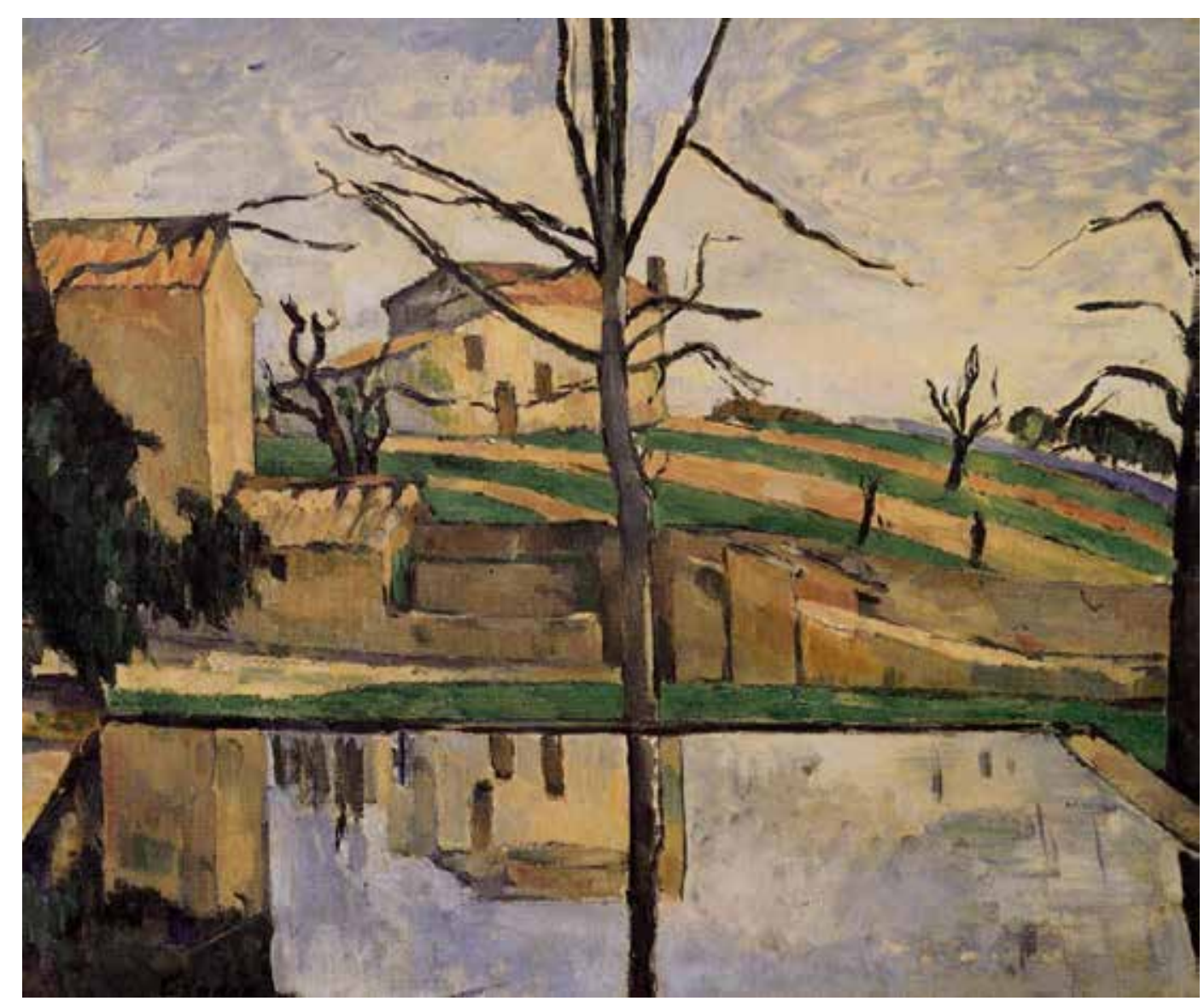

Ao lago [imagem 64], Paul Cézanne, Le Bassin du Jas de Bouffan en hiverc. 1878 . óleo s/ tela, $47 \times 56 \mathrm{~cm}$. Coleção Privada.

https://www.cezannecatalogue.com/catalogue/ entry.php?id=346
É comum às composições de Cézanne uma primeira faixa horizontal muito marcada, dividindo o primeiro plano do segundo, que contém por sua vez outras faixas horizontais, sempre moduladas por um elemento vertical forte e centralizado, como ocorre também no seu icônico $O$ grande pinheiro, o que seria considerado inadmissível na harmonia compositiva dos modelos acadêmicos. O pintor costuma, à inspiração de Poussin, 
3. A respeito deste assunto, o famoso ensaio de 1948 de Maurice Merleau-Ponty, intitulado $A$ Dúvida de Cézanne, elabora uma rica reflexão sobre a liberdade, que não precede dos psicologismos acerca da suposta esquizoidia de que o pintor padecia, para demonstrar que sua obra era um moto do seu próprio ser, correspondendo à necessidade de reciprocidade entre a vida e a obra. se utilizar dos elementos arquitetônicos à distancia para modular a horizontalidade dos primeiros planos. Mas Cézanne o faz com um olhar já não mais idealizado, e, sim, consciente de uma ordem moderna da paisagem, em que a frontalidade já se aproxima da paisagem da vida urbana, em que planos horizontais sobrepostos se escondem parcialmente uns nos outros, encobrindo o horizonte.

A ordenação proposta por Cézanne não é outra senão a de sua própria visão, assim como o são as distorções a que submete determinadas formas em função da composição. A má fama que teve de ser um desenhista pouco hábil se confunde em diversas ocasiões com uma série de hipóteses acerca de sua visão "incorreta" ou "distorcida" dos objetos. Muitos inclusive consideraram que tal fato se devia à sua estranha condição psíquica, e que era isso o que tornou seu olhar tão singular; mas tal tese é extremamente frágil e não nos leva a qualquer discussão construtiva acerca de sua obra. ${ }^{3}$ Se as deformações a que submetia as formas da natureza são intencionais ou intuitivas, nunca saberemos, mas sabemos, como nos informa Clark, que Cézanne "[...] mesmo no período do naturalismo triunfante, definia a pintura como uma harmonia paralela com a natureza.”(1961, p. 157)

À parte a questão das distorções da forma, as descobertas de Cézanne em sua linguagem pictórica passaram a tornar a pincelada interrompida dos impressionistas um recurso expressivo com um sentido renovado. Vemos no quadro acima que linhas retas são configuradas pelas pinceladas sucessivas que representam as folhas das árvores. Mas são retas que se interrompem aqui e ali ao serem entrecortadas pelos troncos e galhos, sem que seu movimento continue após à interrupção. Como afirma Clark, é uma estratégia para que não se quebrem a tensão e o movimento geral da pintura. $\mathrm{O}$ pintor,

Os recursos pictóricos e princípios compositivos de Cézanne, apesar de ricos e complexos, não consolidaram propriamente um estilo, sistema ou método a ser aplicado, uma vez que sua linguagem estava em constante mudança, como se a cada quadro 

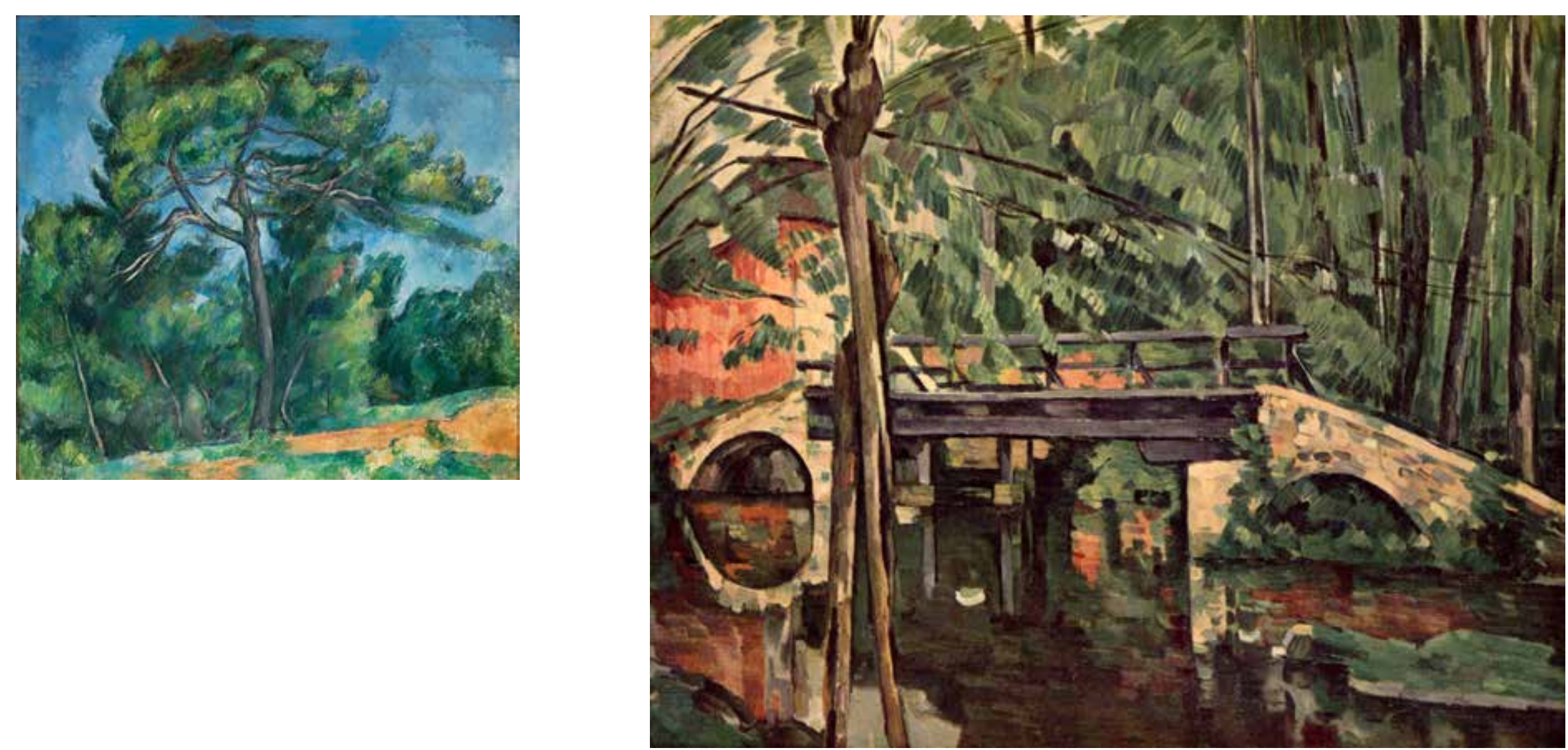

Acima [imagem 65], Paul Cézanne, $O$ grande pinheiro. 1890-1896. Óleo s/ tela $85.5 \times 92.5 \mathrm{~cm}, \mathrm{Mu}$ seu de Arte Assis Chateaubriand, São Paulo.

Fonte:https://masp.org.br/acervo/obra/ogrande-pinheiro

Ao lado [imagem 66], Paul Cézanne, $A$ Ponte de Maincy, 1879, óleo s/ tela 58 x $72 \mathrm{~cm}$. Musee d'Orsay, Paris, France

Fonte:http://art-cezanne.com/cezanne_1870_second_29.html

estivesse obstinado a aprender novamente a ver e a pintar a paisagem, o que não significa que ele tivesse a necessidade infantil de buscar uma fatura original para cada pintura. Ao contrário, sua busca era a de manter-se fiel à sua visão e à percepção, para assim levar sua linguagem e expressão arduamente conquistada a lugar algum, de modo que nunca se acomodou em um estilo ou técnica conquistada, rumando para a decadência de sua pesquisa, como costuma ocorrer com a maioria dos artistas após atingir a maturidade. 
A obra de Cézanne é de uma riqueza tal que não cabe aqui nos deixarmos levar pelo fascínio que ela exerce a qualquer estudioso da pintura. Enfatizemos então naquilo que nos compete: reconhecemos em nossas pinturas da paisagem do rio Pinheiros algo que se relaciona mais com a visão de Cézanne do que com a dos impressionistas, pela sua frontalidade, pela solidez das formas e pelo caráter arquitetural da composição. O que não quer dizer que haja qualquer semelhança entre elas na fatura ou na técnica de pintura, que é visivelmente diferente.

O sentido de tais comparações é sempre o de situar a representação de nossa paisagem empírica em relação à história das paisagens na arte, partindo da compreensão de que há no próprio ato de se olhar a paisagem uma linguagem decantada pela cultura visual, que se sobrepõe à percepção e à experiência da paisagem. Do estudo histórico fundado nestas aproximações, cujo critério intuitivo é o da semelhança visual, entendemos sermos capazes de depreender certas intenções cativas do imaginário paisagístico em direção à paisagem empírica, buscando não uma depuração destas influências, mas, sim, a constituição de um vocabulário que exprima verbalmente os critérios de apreciação de algo que nos é comunicado pelo mundo visto, sob os termos das sensações e percepções. Há, nessa operação, o risco de se incorrer em uma perda da "saudável ingenuidade" desinteressada da criação artística; mas é importante sempre reafirmarmos a autonomia da pesquisa prática em relação à paisagem do rio Pinheiros daquela, teórica e histórica, que é motivada, em função da produção pictórica, pela busca de uma consciência daquilo que pode nos informar este modo de contato sensível com o mundo, que se configura em paisagem.

De modo geral, podemos dizer que a ruptura com os impressionistas promovida por Cézanne, que deixa de lado o principio unificador atmosférico da luminosidade, reside na sua "arquitetura pictórica”. Segundo Clark, parece ser ela um princípio ou qualidade 
unificadora das paisagens cezannianas, que se desdobra no modelado prismático que viria a ser inspiração à invenção do cubismo. Para além de um caráter construtivo das formas, há em Cézanne uma cor atmosférica, conquistada por sua prática intensa e pelas lições de impressionismo que teve com Pissarro; mas há um outro caráter atmosférico que se pronuncia mais do que a luz e a cor nas suas paisagens: uma profunda tensão espiritual manifesta no jogo vibrante de suas pinceladas retas e interrompidas. Cada pincelada parece ser calculada em termos de um perturbação geral que agita suas paisagens e, diferentemente da pincelada interrompida de Van Gogh, cuja tensão é de vocação "expressionista”, a de Cézanne não se constitui nunca em um padrão gráfico, não se prestando a um caráter decorativo.

“É isto que distingue Cézanne dos impressionistas. O impressionismo também tinha uma maneira de dar a modelação contínua por meio da cor, que foi desenvolvida por Seurat; mas subjazendo a todo o impressionismo ficava a crença de que a unidade da pintura depende da atmosfera envolvente, dada por uma trama contínua de cores; enquanto que Cézanne procurava que as formas conservassem a sua identidade numa relação arquitetural. Para o conseguir, portanto, começou por escolher temas em que as formas permitissem este tipo de simplificação." (1961, p. 158)

A expressão mais madura da paisagem de Cézanne teria sido alcançada na passagem do século XIX ao XX, em que figuram suas vistas da paisagem de Aix-en-Provence, protagonizadas pelo monte Sainte-Victoire. Temos aí já uma linguagem visual em que se pronunciam igualmente a percepção visual e as sensações apaixonadas de uma visão mais imaginativa, que retoma uma intenção presente em imagens fantásticas do inicio de sua carreira. Cézanne “[...] realizara a sua própria definição de arte: criar uma harmonia paralela à da natureza. O fator unificador era o seu próprio temperamento.” (1961, p. 162-63). 


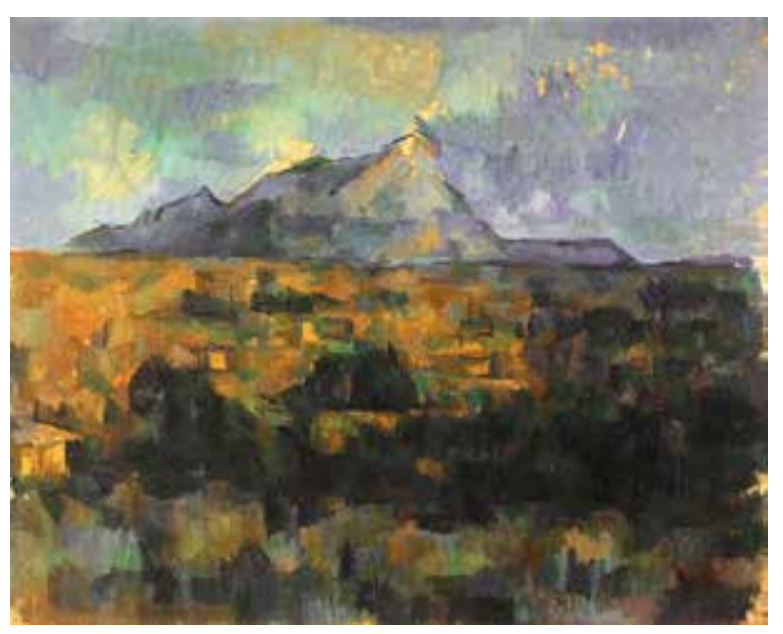

Acima [imagem 67], Paul Cézanne, La Montaigne Sainte-Victoire vue des Lauves, 1904-1906. Óleo s/ tela, $65 \times 81 \mathrm{~cm}$, Emil G. Buhrle, Zurique. http://www.cezanne-en-provence.com/en/gallery/the-sainte-victoire-mountain/

Ao lado [imagem 68], Paul Cézanne, La Montaigne Sainte-Victoire vue des Lauves, 1904-1906. Óleo s/ tela, 60x $73 \mathrm{~cm}$, Museu Puchkin, Moscou. http://www.cezanne-en-provence.com/en/gallery/the-sainte-victoire-mountain/

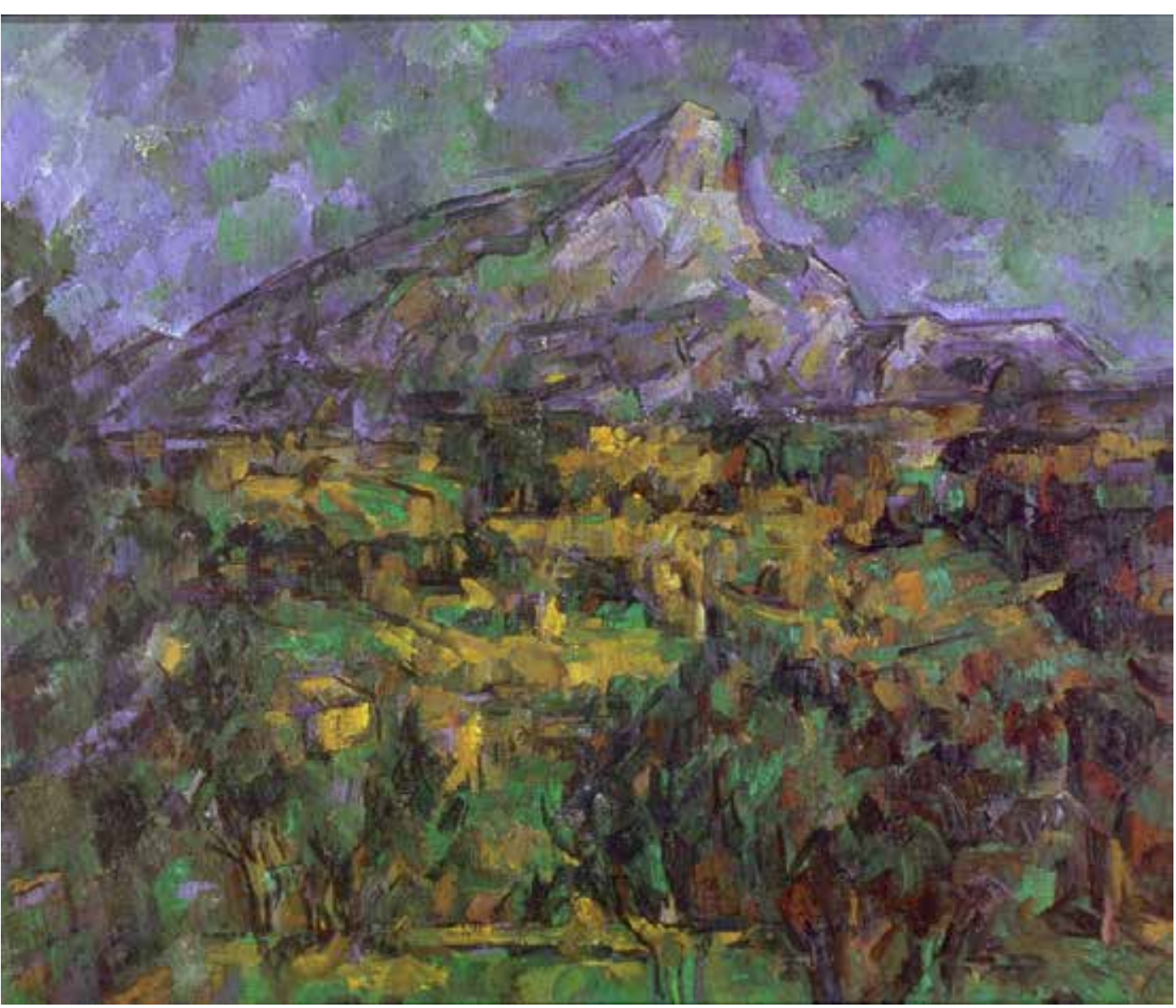

Ainda que a fidelidade à natureza fosse uma máxima para sua visão, os seguidores de Cézanne privilegiaram como legado a componente estilística construtiva de sua linguagem, apropriando-se do caráter eminentemente moderno de sua obra. Como bem resume Clark, a lição peculiar de Cézanne à pintura, que o liga mais diretamente à arte moderna e abstrata, “[...] consistia na realidade na sua crença de que o quadro deve ser 
visto em superfície e em profundidade simultaneamente e que a forma deve ser dada pela cor."(1969, p.163) É, nesse sentido, interessante apontar que, na poética de Cézanne, duas concepções antagônicas da imagem pictórica se articulam, ao invés de se excluírem: na tela, a paisagem é percebida tanto como superfície quanto como profundidade. Há aí uma filiação profunda à experiência perceptiva da paisagem, um sentido positivo de que, mesmo na arte, a natureza se vê em profundidade, e que esta profundidade não entra em conflito com a planaridade da superfície da tela. Para se efetivar enquanto linguagem autônoma, a pintura não necessariamente tem de ser só superfície, reconhecendo uma sua "limitação natural", atendo-se àquilo que lhe é pertinente e abandonando a representação de objetos em profundidade e em espaços reconhecíveis, como quer Greenberg. A autonomia da pintura moderna já está dada por seus próprios meios expressivos, e não é pela referência às aparências naturais que se torna mais ou menos elevada como arte.

\section{A destruição das aparências e a pureza estética}

Se a paisagem na arte, como queremos afirmar desde o início, surge e se transforma mais por razões internas à linguagem artística do que por razões externas a ela, por outro lado, o espírito filosófico de seu tempo tende a se refletir direta ou indiretamente sobre as questões técnicas da arte, e, por meio delas, incidir sobre a linguagem. A imitação da natureza, que permeou a arte européia desde o Renascimento até o final do século XIX, sempre enfrentou tendências de reação contrária a seu princípio mimético, mas a maior delas teve sua origem justamente quando o método criado para se imitar a natureza atingiu, na geração dos impressionistas, um grau inédito de elaboração, em que não mais estava vinculada a uma construção idealizada da experiência visual: a percepção 
visual passou a se impor sobre o espaço perspectivado, dando novo estatuto científico às experimentações de representação da luz e das relações entre figura, fundo e horizonte, tal como percebidas pelo olho. Como resume Clark, o aperfeiçoamento de cinco séculos de tentativas de se construir a luz resultou "[...] num método que criava a luz por meio de uma nova combinação da ciência com a sutileza da visão.” (1961, p.167)

A mais simples explicação para a perda de interesse na imitação das aparências naturais entre os séculos XIX e XX é a do surgimento da fotografia. No caso, uma razão interna também à própria arte. As primeiras fotografias já tinham vocação paisagística, e, à medida em que se tornaram mais frequentes e difundidas, as paisagens fotográficas contribuíram para o desenvolvimento de uma pintura de paisagem que tentava se afastar delas, ainda que com elas também tenha aprendido a olhar o mundo novamente. A pintura moderna procurava, então, uma outra forma de trazer a realidade da experiência do visível, e, de certa forma, a fotografia influenciou tal movimento positiva e negativamente: positiva por propiciar aos artistas um alargamento da experiência estética, para além das imagens gráficas e da observação da natureza; negativa por estabelecer um senso comum de que não haveria mais razão para que a pintura se ocupasse de produzir imagens do mundo externo, pois a fotografia esgotara tal possibilidade.

Clark sustenta a hipótese de que a fotografia tornou possível a criação de uma "arte de museu"no século XIX, que não mais concentrava o ideal clássico da arte que habitava os museus desde o renascimento. A arte de todas as épocas, da antiguidade e de países distantes da cultura eurocêntrica, passou a influenciar a busca estética dos artistas por um choque de visualidade, contraposto à solidez da tradição clássica. A arte primitiva ou da Idade Média seria dotada, então, de uma qualidade estética "pura”, cujo valor era muito mais profundo do que aquele da tradição clássica, e seria essa qualidade que mobilizará, por exemplo, Picasso a interessar-se pelas máscaras de tribos africanas. 
"A arte de museu, portanto, no sentido que estou a empregar, implica a existência da sensação estética pura. Implica que o valor da arte depende se uma essência misteriosa ou de um elixir que pode ser isolado, quase extraído do corpo ou da pele da obra. E este elixir só por si, vale a pena ser investigado.

Se o purismo é perigoso em todas as artes, é particularmente perturbador na pintura

de paisagens que dependem muito da atitude inconsciente de todo o ser perante o mundo que o rodeia."(1961, p.168)

Como nos conta Clark, é quase irônico que a fidelidade à experiência e à percepção do mundo visto, nutrida por Cézanne, tenha sido assimilada como algo tão cerebral e erudito quanto o cubismo. A tendência à simplificação de planos e a abstração das formas naturais era em Cézanne mais um meio do que um fim para poder exprimir em linguagem visual sua percepção da paisagem.

Sendo assim, a hipótese de Clark de que a fotografia propiciou uma arte de museus indica que ela não é culpada pela suposta morte das paisagens na arte moderna, mas sua influência passa por uma rede complexa de circunstâncias sociais e culturais que deram lugar a um novo estatuto da arte, em que o gosto popular e o gosto informado estão cada vez mais distantes. Em meio a tal ambiente, temos o ativismo vanguardista em prol da pintura "pura”, como no exemplo do teórico soviético Pável Floriênski. O modelo de pureza da pintura a ser seguido, para ele, seria o da pureza de cores e da construção geométrica da arte dos ícones russos medievais, uma pintura absolutamente intelectualizada, embora ainda "figurativa". Para Floriênski, quanto mais o pintor se afastasse da imitação da aparência natural, colocando à prova a sua invenção, fazendo com que o ícone fosse visto segundo o modo de ver de sua própria visualidade, maior era a realização deste artista. O que é importante depreender da defesa deste pensador é que a pureza estética prescinde, portanto, da abstração e da geometria pura; ela não faz distinção entre figuração e abstração. Mas esta sutileza não era compartilhada pela visão 
dos partidários mais ferrenhos do abstracionismo.

Para nos demonstrar o que estava em jogo na crítica às aparências naturais, Clark faz referência às palavras do historiador Alfred Barr: "Dado que a semelhança com a natureza é quando muito supérflua, e no pior dos casos, dispersiva, pode também ser eliminada”. $\mathrm{O}$ idealismo platônico que tomou conta da arte abstrata não poderia ser mais desanimador àqueles artistas que buscavam na experiência sensível uma fonte para sua pintura. Os princípios científicos da aplicação da geometria para a criação de obras arquitetônicas, de engenharia mecânica e da tecnologia em geral, que tanto impressionaram Marinetti e Le Corbusier como ideal a ser seguido para uma arte do futuro, passadas algumas décadas, mostraram-se pouco férteis à criação pictórica e gráfica, talvez pela negação exacerbada e intelectualizada da sensualidade e organicidade das sensações e da experiência visível. E a paisagem é uma forma privilegiada de se exprimir essa qualidade: "De todas as formas de arte, a pintura de paisagens encontra-se afastada tanto da geometria platônica como das artes da engenharia, que são uma aplicação elaborada dos mesmos princípios." (1961, p.174)

A paisagem como forma peculiar de se exprimir a experiência teve, assim, seu "fim" decretado em meio a um contexto histórico em que, tanto pelo avanço científico quanto pelas guerras totais, extrapolaram-se as concepções da experiência da natureza. $\mathrm{O}$ desenvolvimento científico do século XX nos mostraram imagens dos níveis subatômicos e intergalácticos do natural, que não nos são acessíveis pela experiência sensível. A história nos mostrou que a estabilidade da ordem natural terrestre fora abalada pela iminência das catástrofes e pelo comportamento da física no seu nível quântico. Dado o cenário, a perspectiva que se tinha para a paisagem na arte apos à segunda guerra mundial era pouco receptiva a uma assimilação positiva e harmônica da natureza.

A visão de Clark era a de que, se havia alguma possibilidade para a paisagem, era 
no campo dos "expressionismos", assumindo-se que a paisagem seria ainda um receptáculo para a expressão das emoções do indivíduo diante do espetáculo apocalíptico da sociedade e da violência natural. "Nas nossas novas guerras de religião esperemos vir a ter um outro Grünewald ou pelo menos outro Bosch. Mas serão aceites?”(1961, p.177)

Ao apontar para um olhar expressionista, no entanto, não é de uma regressão à expressão dos pintores modernos do Norte como Van Gogh, Munch e os artistas do Cavaleiro Azul. Do mesmo modo, podemos supor que, como historiador britânico, Kenneth Clark não nutria a melhor opinião sobre a pintura norte-americana ao final da década de 1940, e estava distante do meio em que viria a ser desenvolvida a última das grandes vanguardas artísticas modernas. Estaria ele de algum modo apontando para uma qualidade paisagística que se afiguraria no iminente expressionismo abstrato?

\section{2}

\section{A paisagem na pintura desde os anos 1950 - figuração $x$ abstração}

Diante da situação colocada na arte das vanguardas históricas, a paisagem da naturalista, da representação da experiência visual, foi colocada em cheque. A recorrente "figuração" e a representação mimética do espaço e do mundo percebido sustentam uma questão aparentemente não resolvida na pintura: a questão colocada pelo advento da fotografia em relação à observação direta como forma de contato que move a poética na linguagem pictórica. Há um dualismo que persiste, mas que já há muito se mostra datado e simplificador, e inúmeros bons exemplos o atestam, como a obra do pintor contemporâneo Gerhard Richter, que pinta a fotografia como um ready made, ao mesmo tempo em que pinta "abstrações" como gênero pictórico.

Não seria exagero, portanto, afirmar que, entre outras razões, a pintura sobreviveu 
à "crise do pintar" após as vanguardas artísticas com a superação de um paradigma dualista entre o figurativo e o abstrato. Por mais que seus postulados afirmassem o fim da figuração na arte, de algum modo o expressionismo abstrato, nos anos 1950, já continha implícito um movimento em direção a certa conciliação entre a radicalidade abstrata e a expressividade surrealista, esta ainda calcada em uma figuração. Uma “volta à pintura”, encabeçada pelos neoexpressionistas alemães nos anos 1980, seria a primeira manifestação recente do "regresso figurativo", dando à pintura um novo fôlego que até hoje, de certa forma, perdura. Em meio a esse contexto de renovação, a produção de pinturas de paisagem alimenta e constitui parte significativa da obra de grandes pintores contemporâneos, que não hesitam em transitar livremente entre uma representação de ordem "mimética" do mundo percebido e uma pintura mais construtivista, abstrata e geométrica. Para além da superação de um paradigma formal dualista, vemos na presença da paisagem na pintura contemporânea um forte caráter historicista, de citação da tradição em uma reinterpretação da pintura histórica, que observamos em artistas alemães como Kiefer e Richter; assim como a presença de uma paisagem em que não mais se busca a atualidade da experiência, mas, sim, a componente da memória que reveste a noção de paisagem.

Depois de um exame das considerações de Clark sobre o declínio da visão natural e a consequente ordenação abstratizante da arte moderna, nosso intuito, daqui em diante, é caracterizar uma linha sucessória da atitude moderna diante da paisagem, os novos olhares que surgem no contexto contemporâneo. Pretende-se, assim, subsidiar a discussão acerca das qualidades visuais presentes nas nossas paisagens do rio Pinheiros, na medida em que identifiquemos, nas obras de dois pintores, Diebenkorn e Paulo Pasta, aspectos da linguagem que se traduzam em critérios de apreciação sobre a paisagem na pintura pós-vanguardista, situando-nos historicamente quanto à questão posta desde Seurat e Cézanne, o "regresso à ordem" de que nos falou Clark. 


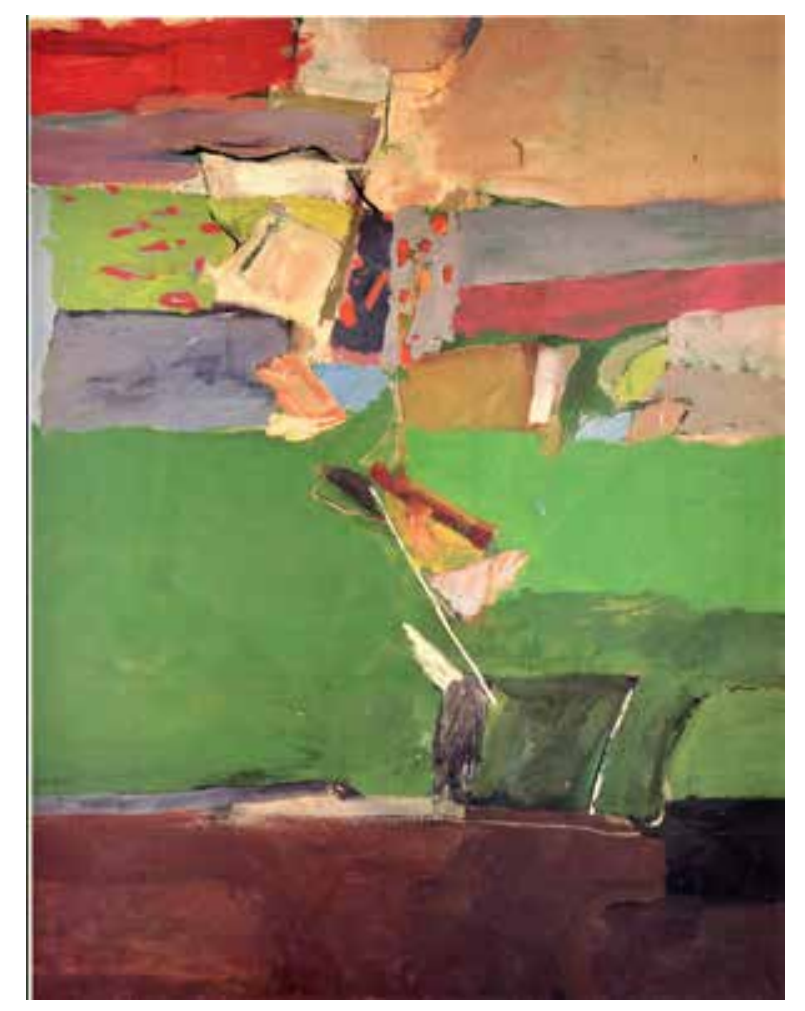

Acima [imagem 69], Richard Diebenkorn, Berkeley \#13, 1954, óleo s/ tela, 176 x 138cm. Diebenkorn Foundation Berkley.

Fonte: https://collection.diebenkorn.org/objects $/ 112 /$ berkeley-13?ctx $=$ f5e $53009-338 \mathrm{a}-474 \mathrm{a}-$ 9338-47419816bc0e\&idx $=0$

\section{O exemplo de Richard Diebenkorn}

Nos prenúncios da pintura tida como contemporânea, à sombra do surgimento da pop art e da radicalidade heróica do expressionismo abstrato, surge uma rejeição aos imperativos da abstração, ainda nos EUA dos anos 1950. Tal rejeição vem possibilitar um retorno à figuração ainda investida de expressividade: nas obras de pintores de vulto como Richard Diebenkorn (1922-1993), vemos uma clara ênfase na paisagem para a constituição de sua linguagem. O pintor que, no início da carreira, notabilizou-se como integrante de uma vertente "lírica" do expressionismo abstrato, em um segundo momento afastou-se da academia e passou a integrar um conjunto de pintores da costa oeste norte-americana, protagonizado por David Park. Numa guinada "figurativa" em meados dos anos 1950-1960, em que registrou as formas e vivas cores da atmosfera litorânea da Califórnia, Diebenkorn integrou o Bay Area Figurative Movement. Já nos anos 1970, verifica-se, na maturidade do pintor, uma nova síntese abstratizante, geometrizada segundo uma decomposição cromática fortemente matissiana, daquilo que se coloca nas paisagens de sua fase "figurativa".

Richard Diebenkorn foi um exemplo de pintor em que é impossível não ver a influência da percepção do ambiente. As variações em sua obra coincidem com a mudança da paisagem que ele via ao seu redor: a cada vez em que se mudava, o aspecto de sua poesia visual tomava novas cores e formas, e a ênfase dada à localidade e à atmosfera luminosa e cromática de onde as obras eram produzidas era tal, que a maioria dos títulos de seus trabalhos é formada pelo nome da cidade onde foram feitos, seguido de um número referente à série que compõem. Ainda que este tipo de título possa ser simplesmente uma formalidade, seguindo uma tradição já vigente em outros artistas seus contemporâneos, em poucos casos foi adotada de maneira tão sistemática quanto por Diebenkorn. Tal ca- 

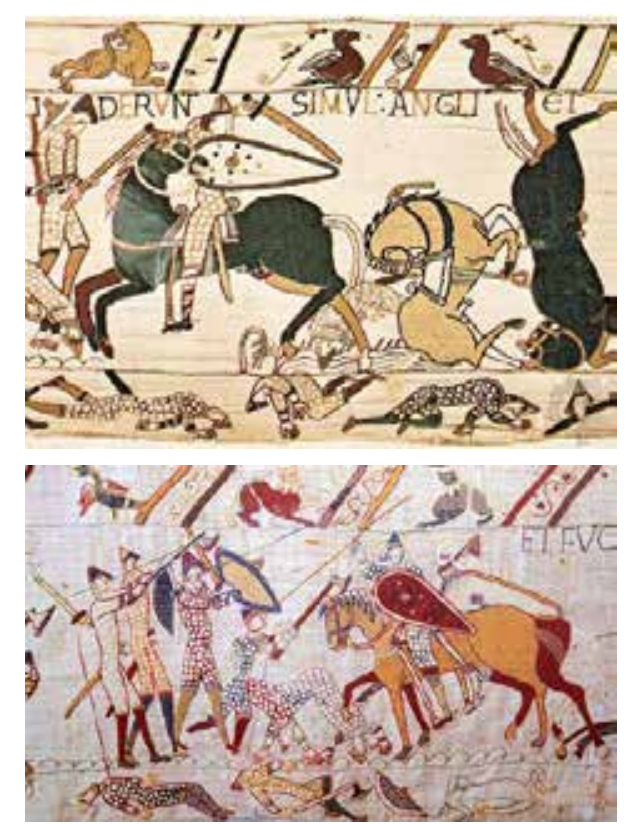

No topo da página [imagem 70] e na sequência [imagem 71], Autoria desconhecida, detalhes da Tapeçaria de Bayeux, que tem no total $70 \mathrm{~m}$ x $49.5 \mathrm{~cm}$. Giraudon/ Art Resource, Nova Iorque.

Fonte:https://www.britannica.com/topic/Bayeux-Tapestry

4. "Richard Diebenkorn: Known and Unknown" palestra proferida em 07/09/2013 por Timothy Anglin Burgard, curador encarregado do Ednah Root American Art, do Fine Arts Museums of San Francisco, na ocasião do Richard Diebenkorn Symposium, realizado em função da exposição the de Young Richard Diebenkorn: The Berkeley Years, 1953-1966, que durou de 22 de junho a 29 de setembrode 2013).

Acessado em: https://www.youtube.com/watch?v=W$7 \mathrm{gObLxwd} 2 \mathrm{k}$ racterística pode ser apontada como indício de uma intenção paisagística específica, que associa a criação pictórica diretamente à cidade em que ela se realiza, por mais que não haja nestas obras a indicação explícita de um registro dos fatos, no sentido "topográfico".

Interessa-nos, então, apontar em sua obra o protagonismo da paisagem. Mais do que dar continuidade a tradições da arte moderna como a de Bonnard, Matisse, e do expressionismo abstrato, Diebenkorn criou espacialidades mentais, imaginárias, simultaneamente abstratas e figurativas, cuja fundamentação se deu no mundo visto, de forma que sua obra mostra-se indissociável de uma identidade paisagística da costa oeste norte-americana, onde passou a maior parte de sua vida como pintor. Por mais que, segundo relatam pessoas próximas, quase todas as suas pinturas de paisagem tenham sido feitas a partir de invenção, ou "de memória", há nelas uma veracidade de cores, de luz e de atmosfera que demonstra uma percepção apurada do mundo visto como paisagem, que nos deixam desconcertados em pensar que não há nelas nenhuma intenção de registro do visível.

Não só nas paisagens de Diebenkorn, mas em suas pinturas em geral, vemos uma estrutura visual tripartida, um mise-en-scene em que se tem sempre um primeiro plano mais próximo, seguido de um espaço que se estende à distância com fortes diagonais e faixas horizontais, seguido por um terceiro plano, mais distante, uma faixa mais estreita que costuma corresponder ao céu. Nem sempre, no entanto, a relação entre as três partes é explícita, e, principalmente em sua primeira fase abstrata (até meados dos anos 1950), cada uma dessas três faixas conserva certa independência em relação às outras. Segundo a hipótese do crítico e curador Timothy Burgard ${ }^{4}$, há indícios de que esta estrutura visual estivesse presente no imaginário de Diebenkorn desde a adolescência, uma vez que sua avó, que foi a maior fiadora de sua vontade de se tornar pintor, o presenteou com uma série de cartões postais com as tapeçarias de Bayeux, relatando a conquista da Inglaterra pelos normandos no século XI. O artista tinha grande estima por essa coleção de postais que 


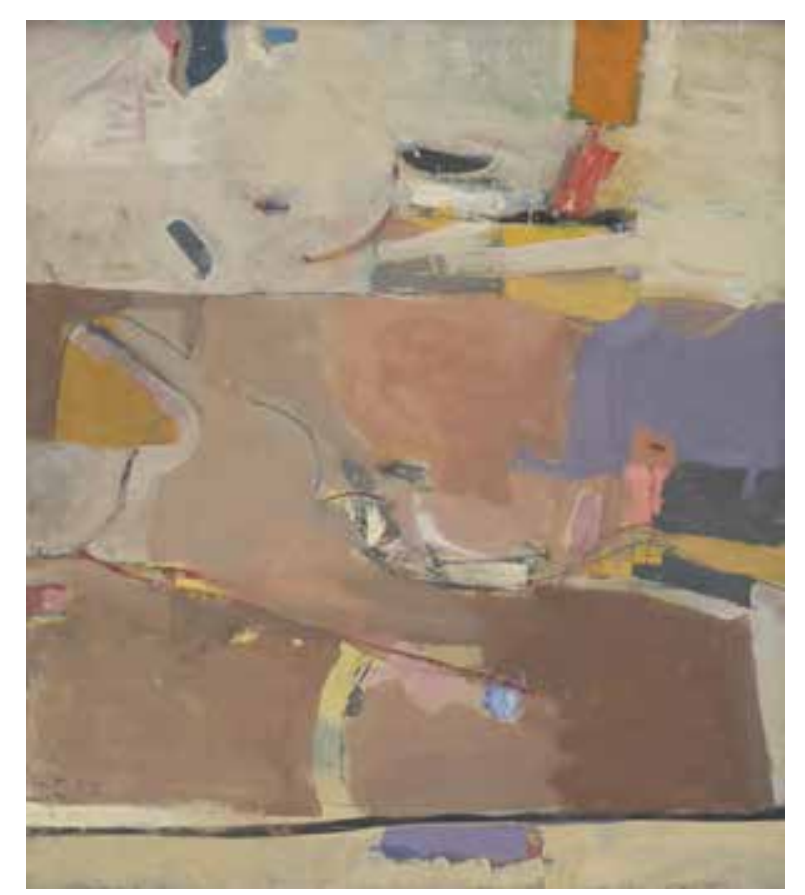

Acima [imagem 72], Richard Diebenkorn, Berkeley \#1, 1954, óleo s/ tela, $153 \times 134 \mathrm{~cm}$. Phillips Collection, Washington, D.C.

Fonte:https://collection.diebenkorn.org/objects $/ 100 /$ berkeley- 1 ?ctx $=27432$ d3c-f843-4d03b9f6-4060de25c912\&idx=3 teriam estruturado uma gramática visual em seu repertório.

Como podemos ver nas imagens, há nessas tapeçarias sempre três planos em que se apresentam cenas e narrativas correlatas, mas visualmente independentes entre si. Comparando-as com suas pinturas da série de Berkeley, temos as três faixas horizontais paralelas, como se fossem diferentes estratos topográficos ou geográficos reunidos em uma só visão. Na tapeçaria de Bayeux, as faixas superior e inferior são menores que a faixa central, e, mais do que cumprirem uma função puramente decorativa, realizam um comentário ou uma visão simultânea e alternativa à narrativa que ocorre ao centro: são desenhos em que há contrapontos entre tempos e espaços simultâneos, e este princípio teria se tornado central na poética de Diebenkorn, revelando-se, com maior ou menor ênfase ao longo de toda a sua carreira, como uma forma "arquetípica" de suas imagens.

A exemplo da obra desse artista, o exame da estrutura visual tripartida, tão comum aos esquemas paisagísticos, pode nos trazer elementos para compreender como a experiência da paisagem como espacialidade é representada. À parte a força simbólica da tríade e do elemento ternário à cultura visual, a divisão do espaço em três estratos ou planos é, também, significativa de uma estrutura perceptiva. $\mathrm{O}$ sentido de profundidade e a relação fundamental entre o aqui e o lá que se tem nas paisagens engendra um sistema ternário.

É possível dizer que a relação perceptual que em geral se tem com a paisagem se configura em, pelo menos, três estratos de espacialidade: um mais próximo, correspondente à imediatez física, o espaço do movimento possível; um mais distante, aquele que se vê ao longe, inacessível ao movimento; e um terceiro, que pode se desdobrar em tantos outros, que é aquele, mediano, que há entre o espaço mais próximo e o mais longínquo. Essa talvez seja uma estrutura constante na representação espacial, e ela se verifica com alguma precisão em quase todas as representações de paisagem: o primeiro plano, o plano 
5. A contradição entre elas se dá justamente em relação à presença do horizonte, que, a rigor, não seria compatível com uma projeção paralela como a da cartografia. Como já demonstramos do capítulo II, esta combinação já se efetivava nas vistas topográficas no renascimento flamengo, em que uma cidade era vista tal qual um mapa, mas seus edifícios não eram planificados, e, sim, dotados de volumetria. Assim como o horizonte e o céu se apresentavam no topo da imagem. Esta tentativa de unir, em uma só visada, o olhar "de cima para baixo", ortogonal ao plano do solo, com uma visada frontal, em que o horizonte

e o céu se mostram, corresponde a um desejo de ampliação da visão, uma vontade de produzir imagens maiores, menos restritivas e recortadas. No entanto, o que ocorreu com a naturalização do enquadramento fotográfico, da imagem cada vez mais recortada do mundo, parece ir na contramão desse desejo de amplidão, que encontra outras propostas, como na obra de Diebenkorn. médio, e o horizonte que divisa com o céu. A questão é, portanto, avaliar como os artistas articulam os elementos dessa estrutura de modo a produzir novas imagens, ou de forma a ressignificar esta estrutura tal como ela se apresenta em outras imagens e representações do mundo visto. No caso da hipótese de Timothy Burgard sobre Diebenkorn, uma representação medieval, de ordem simbólica, traduz-se em uma inovadora expressão pictórica do espaço, que consolidou-se como referência para uma percepção contemporânea da paisagem, dada a influência desse artista na pintura de nosso tempo.

À medida que Diebenkorn consolidava sua própria poética, em meados dos anos 1950, afastava-se da influência de artistas como Willem de Kooning, Clyfford Still e Mark Rothko, pertencentes ao círculo nova-iorquino, a vanguarda do expressionismo abstrato. Suas obras passaram a se tornar cada vez mais paisagísticas, ainda que o artista conscientemente tentasse se afastar de qualquer intenção declarada a esse respeito. É claro que não é possível inferir com certeza qualquer significação literal a essas obras, uma vez que de fato, são abstratas. No entanto, o que propomos aqui é uma aproximação a elas sob a ótica da linguagem visual paisagística, que tanto se reafirma no conjunto da obra desse artista.

Sendo assim, arriscamo-nos a dizer que os espaços mentais das obras deste período de Diebenkorn sugerem um olhar em que se fundem duas vistas comumente tidas como contraditórias": a vista aérea- a "vôo de pássaro"- e uma visão perspectivada, em que se localiza a posição de um espectador em relação a um horizonte em profundidade. As manchas e zonas de cor que compõem as pinturas nos remetem às paisagens do campo cultivado, às estradas, às topografias e relevos entrecortados e trabalhados, evocando a construção dos artefatos humanos, em sua relação com um terreno natural que se vê de cima, em direção a um horizonte distante. Como na tradição das paisagens, há sempre algum elemento linear, diagonal ou não, que corta transversalmente o plano mediano, guiando o olho do plano inferior, mais próximo, ao plano superior mais distante. Para 
além da organização esquemática, há nestas obras um uso da cor que sugere colorações orgânicas, do mundo natural: por mais que se apresentem, aqui e ali, cores industriais, há o predomínio das cores que se aproximam dos tons terrosos e os esverdeados da vegetação; explora-se o potencial cromático com grande riqueza, com áreas de cor sempre contrastando o plenamente iluminado com a cor matizada pela sombra, como se incidisse sobre eles uma luz solar.

Nos seus inícios como estudante de pintura, a característica estrutura tripartida já se evidencia sob a configuração aparentemente comum às visadas paisagísticas. As primeiras paisagens de Diebenkorn carregam forte inspiração nas obras de Edward Hopper, como podemos ver nas imagens a seguir:

À direita [imagem 73], Richard Diebenkorn, Palo Alto circle, 1943, óleo s/ tela, 51 x $51 \mathrm{~cm}$. Santa Cruz island Foundation.

Fonte:https://curiator.com/art/richard-diebenkorn/palo-alto-circle

À esquerda [imagem 74], Edward Hopper, Early Sunday Morning, 1930. Óleo s/ tela. $89.4 \times 153$ $\mathrm{cm}$. Whitney Museum, Nova Iorque.

https://www.edwardhopper.net/early-sunday-morning.jpp
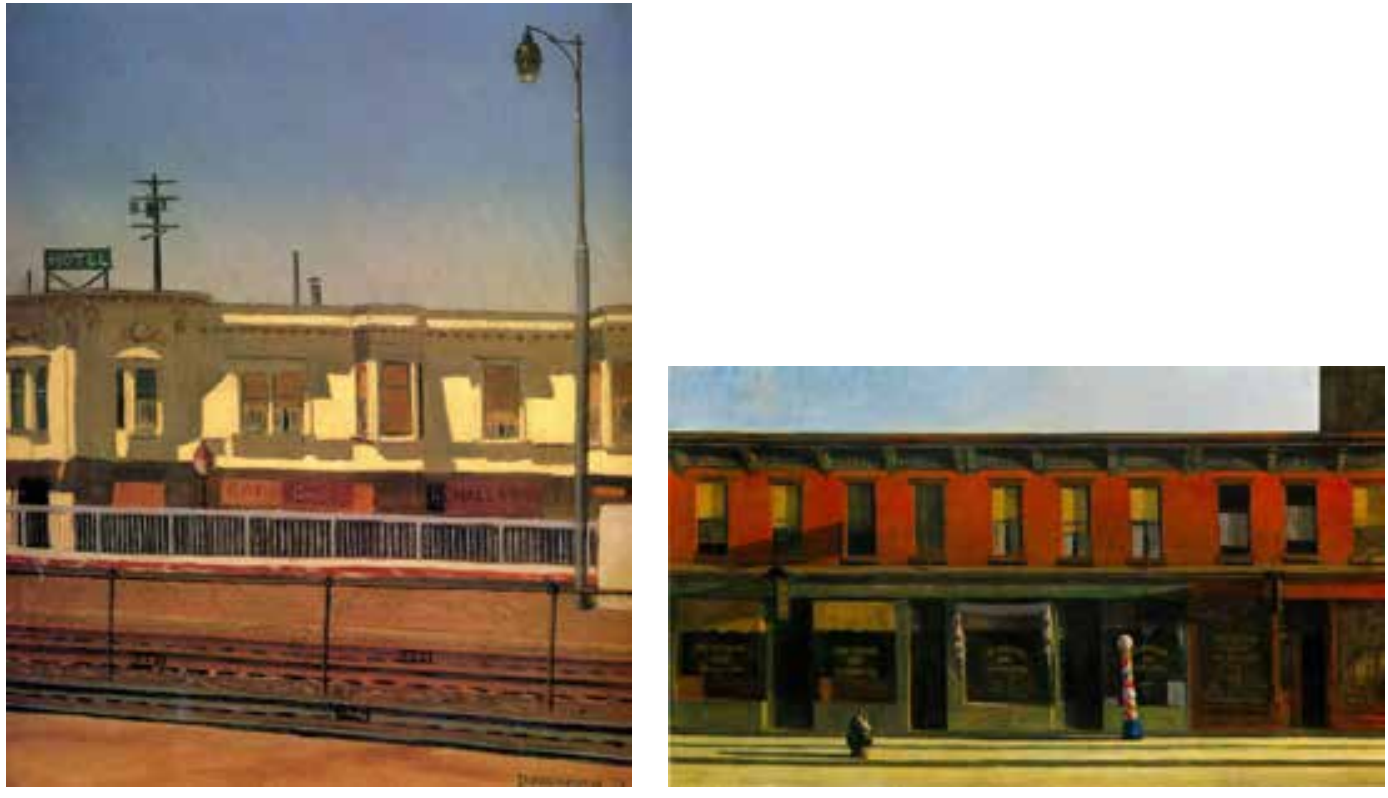
O principal aspecto a se destacar em relação à filiação de Diebenkorn à desolação das paisagens de Hopper é uma intenção semelhante quanto à descrição do espaço: vemos uma certa ênfase na frontalidade de um ambiente urbanizado em que a incidência da luz produz desenhos de sombras projetadas em contraste com as superfícies de cor saturadas pela luz solar. O jogo cromático entre a luz do sol direta e as sombras projetadas foi executado com maestria por Hopper, e é uma das principais lições absorvidas por Diebenkorn na sua fase mais representacional ou figurativa. Diebenkorn deu continuidade à tradição figurativa de Hopper de modo a ampliar o repertório da interação da cor a um cromatismo matissiano, em que temos a realidade e verossimilhança da luz "natural" expressa em termos de um colorismo inventivo e de grande expressividade.

Não podemos deixar de notar que esta mesma frontalidade do jovem Diebenkorn, que marca também suas paisagens figurativas mais maduras, é compartilhada por nossas paisagens do rio Pinheiros, especialmente nas pinturas das margens expostas neste quarto capítulo. Há, inclusive, uma mesma estrutura tripartida, de faixas horizontais paralelas de larguras semelhantes em que linhas retas, sutilmente inclinadas em relação à horizontalidade do quadro, realizam o jogo entre reentrâncias e saliências de luz e de sombra, à medida em que se interrompem e continuam, balizadas por elementos verticais discretos como postes de luz, estacas de uma cerca, ou placas de rua. Nota-se a mesma estabilidade e solidez, por meio de volumes sólidos e precisos que, ao contrário da anti-gravidade cézanniana, se assentam de maneira grave sobre o solo. São paisagens que sugerem a dinâmica e o movimento mais pela sua horizontalidade e pela agilidade das linhas paralelas, do que pela flutuação vertical dos objetos e volumes que se recusam a flutuar.

Entre outros aspectos, é por essa qualidade sólida e precisa que pinturas como Palo Alto Circle, (imagem x) ainda são muito distantes do Diebenkorn maduro, e não se adequam ao expressionismo abstrato ao qual ele iria posteriormente aderir, no qual a 
6. Richard Diebenkorn: Beginnings, 1942-1955, palestra proferida em 8 de setembro de 2018, no Museu de Arte de Portland, por Scott A. Shields, Ph.D., diretor associado e Curador Chefe do Crocker Art Museum, em Sacramento, por ocasião da exposição homônima. Acessado em:

https://www.youtube.com/watch?v=DpXShCkGuo gravidade e o peso material das paisagens dissolve-se em composições abstratas de corpos flutuantes, em que o jogo entre verticais e horizontais torna-se menos constrangido, livre de amarras e de peso, expandindo-se para o espaço além da tela.

Da mesma forma com que, na história da pintura moderna, a gravidade se esvai das paisagens, o caráter representacional da pintura é, aos poucos, abolido pela crítica de arte em meados dos anos 1940. É nesse ambiente que Diebenkorn se forma como artista, lendo revistas como a Dyn, entre outras. O “fim da figuração" foi, já em 1944, uma questão da pintura acadêmica nos EUA, e é nesse contexto que a vanguarda do expressionismo abstrato se estabeleceu. A arte dos museus, com as obras de Braque, Matisse e Picasso e o contato com a história da arte moderna, fizeram com que Diebenkorn rapidamente se adequasse aos novos padrões artísticos, e é a partir daí que sua carreira como artista profissional se inicia. Após o serviço militar, ele ingressou na escola de belas artes da Califórnia e, em 1946, todos os seus professores estavam produzindo abstrações e a instituição vinha se tornando cada vez mais iconoclasta e vanguardista.

No entanto, a paisagem não havia ainda sumido completamente de sua produção, e o artista registrou as bases militares onde serviu à época da Segunda Guerra, além de ter servido como desenhista de mapas pelo serviço da Marinha. É interessante ressaltar que, apesar de seu péssimo desempenho como topógrafo, como nos informa o historiador Scott A. Shields ${ }^{6}$, Diebenkorn pode ter absorvido algo deste caráter de mapista na sua produção expressionista abstrata: a associação de suas pinturas de Berkeley com a visão aérea dos mapas é quase impossível de se negar, ainda que sua produção à época em que trabalhou como desenhista de mapas na Marinha fosse de inspiração cubista e surrealista. Da mesma forma, o artista sempre foi interessado no estudo da tradição das artes visuais e da história da arte em geral, o que o diferenciava entre seus colegas mais aguerridos aos ideais das iminentes referências norte-americanas, a elite nova-iorquina da abstração. 


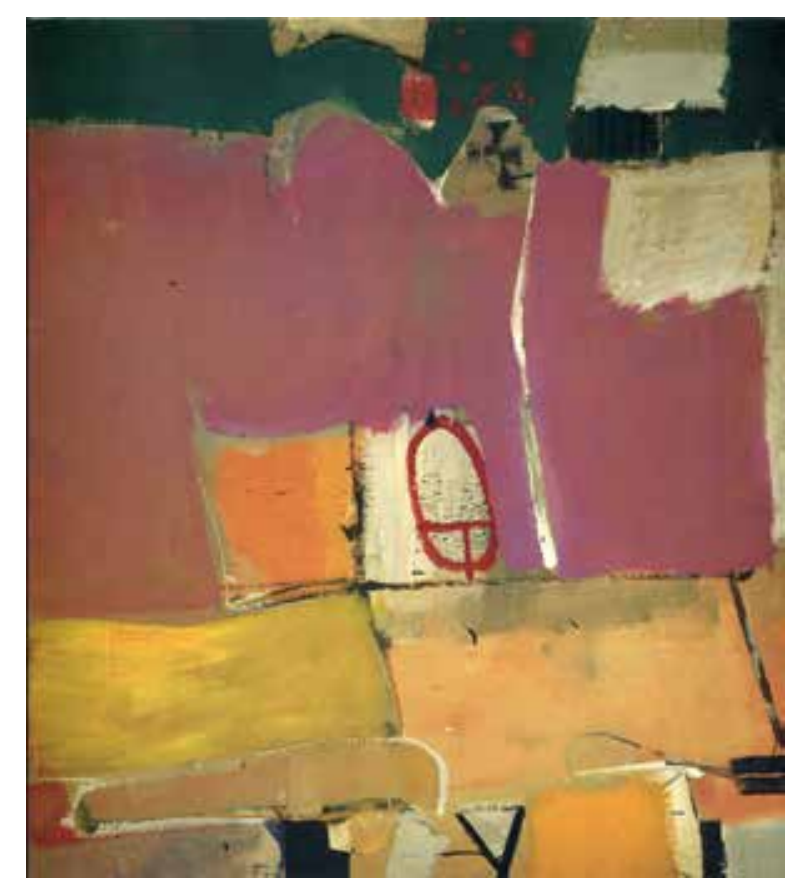

Acima [imagem 75], Richard Diebenkorn, Albuquerque \#4, 1951, óleo s/ tela, $128.9 \times 116.2 \mathrm{~cm}$, Saint Louis Art Museum, St. Louis.

https://www.wikiart.org/en/richard-diebenkorn/ albuquerque-no-4

7. Id., 2018
Segundo nos conta Shields, a pintura de Diebenkorn começou a reconciliar-se com a figura, enfim, assumindo a possibilidade do "assunto" ou "motivo", quando o artista se mudou para Albuquerque, no Novo México, em 1950, por ocasião de um mestrado. As cores mais arenosas, o avermelhado e os tons terrosos do ambiente semiárido, assim como os verdes brilhantes da vegetação, sob uma atmosfera empoeirada, passam a acrescentar notas paisagísticas em suas telas, aproximando-se mais de sua identidade pictórica madura, a que o alçou à fama. A estrutura tripartida e a sensação de vista de sobrevôo já se afiguram nessa fase de maneira convicta. Realiza-se uma plena abstração; no entanto a paisagem é o assunto.

Retomando a análise de obras dessa fase, na porção superior desta pintura, podemos ver o índice visual de uma cruz, que se acredita ser a evocação da Igreja de São Francisco de Assis, em Ranchos de Taos. Segundo Shields, Diebenkorn dizia que pintava paisagens depois de haver estado em presença delas, mas não pintava a paisagem como registro específico. Em uma anotação de próprio punho, o artista escreveu em 1956: "I see nature only when I haven 't looked at it for a while." (informação verbal) ${ }^{7}$

Em relação às vistas aéreas, de fato o artista foi impactado pela sua primeira viagem de avião, retornando de Albuquerque para a Califórnia, em 1951. Em relação a esta experiência, Diebenkorn comentou:

"[...] I guess it was the combination of desert and agriculture that really turned me on, because it has so many things I wanted in my paintings...I mean, it was all like a flat design - and everything was usually in the form of an irregular grid." (Diebenkorn apud Shields, 2018)

Ao mudar-se para Urbana, em Illinois, em 1953, Diebenkorn continuou sua guinada em direção à figuração. Apesar de não apreciar a paisagem da cidade, o artis- 
8. Passagens das notas de Diebenkorn de cerca de 1956, do acervo da Diebenkorn Foundation: https://collection.diebenkorn.org/objects/10815/ artists-writing?ctx $=$ d939b2f8-c08b-4d2f-99da0030da1a5ad9\&idx $=7$

"For me the representation of physical facts such as are found in "landscapes", "interiors", or "figure pieces" has become one of the properties of painting. [...]

In abstract painting I worried about the limited range of possibilities that as time went on became increasingly important to me. I wanted to express or deal with differences that an all-over paint and canvas "presence" neutralized. The common denominator of all the elements I would use, mainly paint and its somewhat consistent handling as well as its manifest adherence to the surface, proved too strong for the shift in emphasis that I wanted in my work. I found that a somewhat literal reinforcement of the differences I sought, such as, outside beside interior, sunlight opposed to gloom, the presence of person opposed to emptiness, made the balance a better one and maintained the kind of differences that I sought. [...] ( Diebenkorn,1956) ta passou a pintar, de invenção, abstrações quase paisagísticas. A icônica pintura Urbana \#5(Beach Town) nos mostra uma paisagem de cidade litorânea, em que uma avenida em perspectiva nos guia em direção à praia, onde vemos o mar ao longe, misturando-se com o céu. O curioso é que o desejo pela praia, muito distante da paisagem desagradável de Urbana, moveu a imaginação do pintor para uma paisagem "meio abstrata, meio-figurativa" cuja composição nos remete a outras pinturas de sua carreira.

A volta à figuração entre os expressionistas abstratos a partir dessa época foi protagonizada por David Park na Califórnia, seu mais estimado professor, mas também por Willem de Kooning. Esta perspectiva se articulava com as aspirações poéticas de Diebenkorn e trazia especial liberdade à sua expressão, que naturalmente já vinha relativizando o imperativo ideal da abstração. Entre os anos de 1953 e 1955, período em que viveu em Berkeley, as telas de Diebenkorn começaram a atingir valores maiores e tal período corresponde ao seu estabelecimento pleno como pintor diante do mercado e da crítica. É curioso notar que, justamente quando acabara de garantir seu lugar no mercado, Diebenkorn se sente compelido a abandonar a abstração, que lhe havia rendido o status de artista reconhecido.

A inspiração para sua reinvenção como pintor passou, então, pelas saídas para visitar museus e para olhar a paisagem, e a primeira pintura de paisagem declaradamente figurativa, intitulada Chabot Valley, data de 1955, dando início a uma fase que duraria pouco mais de uma década. Foi quando Diebenkorn estabeleceu-se como liderança no movimento figurativo da Bay Area, antes protagonizado por seu professor e amigo David Park.

As palavras do próprio artista ajudam-nos a compreender melhor as razões para sua guinada poética, e as palavras externadas em suas anotações de $1956^{8}$ parecem ser parte de uma tentativa de entender e lidar com seus próprios desejos em relação à pintura. Nelas 


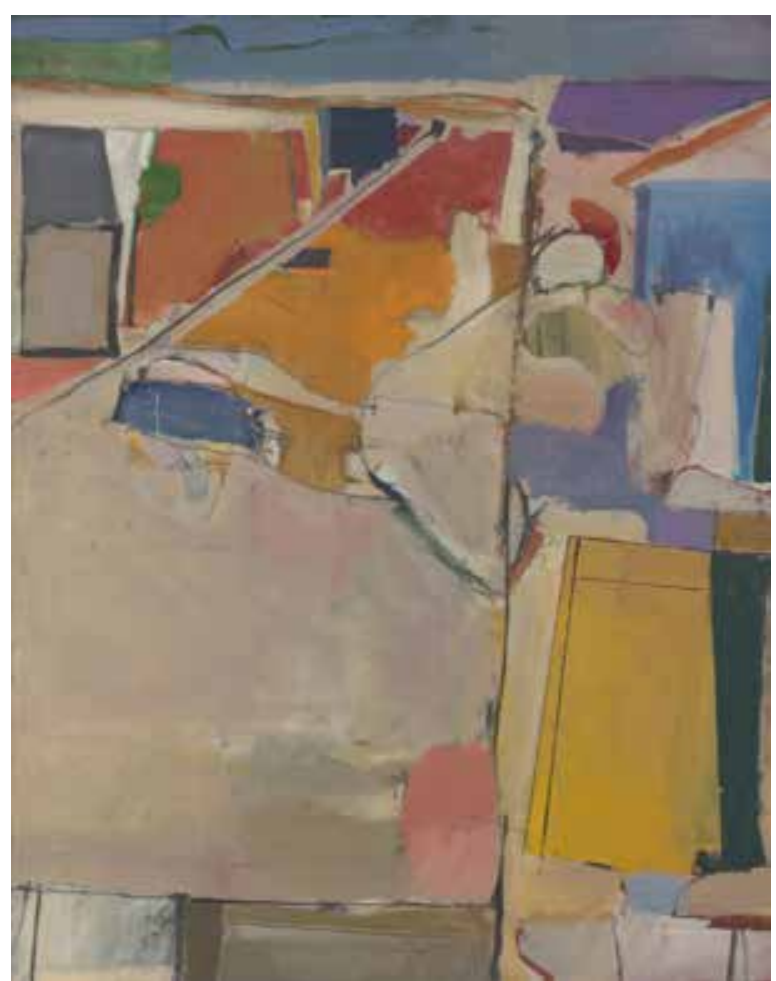

Acima [imagem 76], Richard Diebenkorn, Urbana \# 5 (Beach town), 1953, óleo s/tela, 172 x $136 \mathrm{~cm}$. Diebenkorn Foundation, Berkeley

Fonte:https://collection.diebenkorn.org/objects $/ 98 /$ urbana-5-beach-town?ctx $=27$ af5f75 $7 \mathrm{e} 09-49 \mathrm{f} 9-\mathrm{bc} 8 \mathrm{~d}-4 \mathrm{dbdbc1a3b6c \& idx=0}$ o pintor explica que a necessidade que sentia de expressar "diferenças" em suas obras, seria reforçada pelos contrastes entre o "espaço exterior e o interior, a luz do sol oposta à penumbra, a presença de uma pessoa oposta ao vazio", contribuindo para alcançar um maior equilíbrio entre as diferenças que buscava exprimir. Ou seja, os recursos representacionais mostraram-se uma forma de expressar relações que o princípio da "all over painting" do expressionismo abstrato, acabavam por neutralizar. Os princípios que norteavam a pintura de Diebenkorn até então, segundo suas próprias palavras, eram: a criação de ambigüidades espaciais; a exposição clara, decodificada, "soletrada" da intensidade; e a infinita "sugestionabilidade" das formas, um dos princípios chave de um abstracionismo puro.

"Just as I once believed that spatial ambiguities, intensity spelled out, and infinite suggestibility were necessary properties of painting I now believe that the representation of men, women, walls, windows and cups are necessary." (DIEBENKORN FOUNDATION, 1956)

É interessante notar como, em termos de fatura, composição e do uso da cor, a pintura figurativa de paisagem de Diebenkorn é muito semelhante às suas abstrações expressionistas anteriores. As vivas e violentas pinceladas e a cor fauvista que Diebenkorn absorveu da tradição matissiana incorporaram-se a um novo tipo de realismo no tratamento dos fatos, luz e cores da paisagem, que traz a indefinição de linhas e volumes de um olhar que não vê pormenores, mas sim a impressão geral da luz, sem, no entanto, recair na fragmentação dos espectros de luz impressionistas. Há uma unidade geral de indefiniçãao e de embaçamento da forma em Diebenkorn, que não é produzida por um artifício de pincel, como o sfumato (utilizado, na arte contemporânea, no fotorrealismo das paisagens de Gerhard Richter, por exemplo), mas pela pincelada bruta que, com camadas de cor sobrepostas, sucessivos apagamentos, raspagens e recobrimentos, conferem às formas 


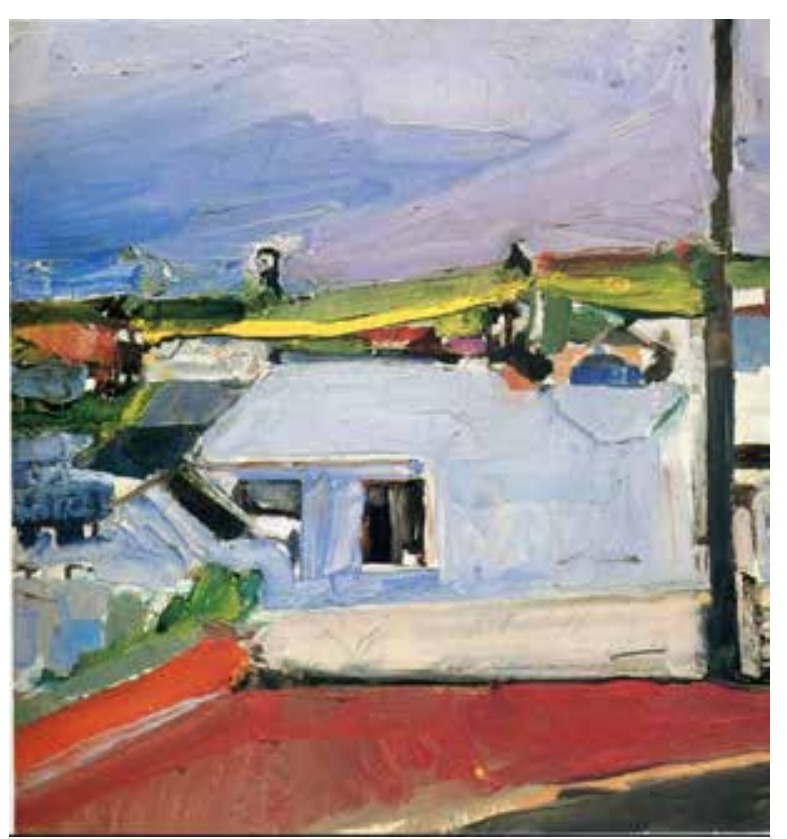

Acima [imagem 77], Richard Diebenkorn, Chabot Valley, 1955, óleo s/ tela. $19^{1 / 2} \times 18$ 3/4 in.

Fonte:https://www.wikiart.org/en/richard-diebenkorn/chabot-valley uma vibração dinâmica, resultante das incongruências entre vários perfis concorrentes de uma mesma forma. Esta característica é reforçada pelo desenho de linhas retas que são retas somente em potência, pois acabam indefinidas pela pintura e cadenciadas pelo encontro com tantas outras linhas vacilantes, sutilmente tortas, diagonais sutis e vacilantes, que contribuem à sensualidade do mundo visto por Diebenkorn, em que as formas retas e construídas parecem ganhar vida e movimento, sem que se crie uma identidade caricata, ou uma animação forçada aos corpos inanimados.

A composição das paisagens de Diebenkorn tenciona sempre as linhas de força que imprimem profundidade e perspectiva ao espaço: as diagonais são violentas e dramatizam o movimento do olhar em direção à distância, havendo nelas um sentido algo "entrópico" da percepção visual. No entanto esse jogo agressivo de linhas em movimento se dá nas entrelinhas de uma horizontalidade, parcialmente neutralizado em uma ordem frontal, que confere certa harmonia às composições.

As paisagens de Diebenkorn do final dos anos 1950 interessam sobretudo à nossa comparação com as paisagens do rio Pinheiros, uma vez que há nelas um sentido específico de ênfase na interação de forças na paisagem. Vemos nelas um conflito de linhas em movimento, conjugando a água, a construção da cidade, o relevo e a vegetação, que trazem à tona um olhar especialmente representativo do que vem a ser a paisagem nas ambientações urbanas. A coloração naturalista da natureza no meio urbano é, também, a mesma de nossas paisagens: sombras marrons em profundidade, recobertas por tonalidades diversas de verde da vegetação e os brancos acinzentados do concreto, matizados pelos ocres e amarelos da terra, da poeira e da luz solar; o azul celeste ocupando a faixa superior. É sobretudo uma questão de restrição ao cromatismo na pintura, ter de enfrentar a auto-evidência das cores naturais. Depois das conquistas do colorismo e da autonomia das cores puras na arte moderna, é um desafio ao pintor ter de lidar com a paleta relativa- 
Ao lado [imagem 78], Richard Diebenkorn, Freeway and Aqueduct, 1957. óleo s/ tela, $64.7 \times 75.5$ cm. LACMA, Los Angeles.

Fonte:https://collections.lacma.org/node/252097

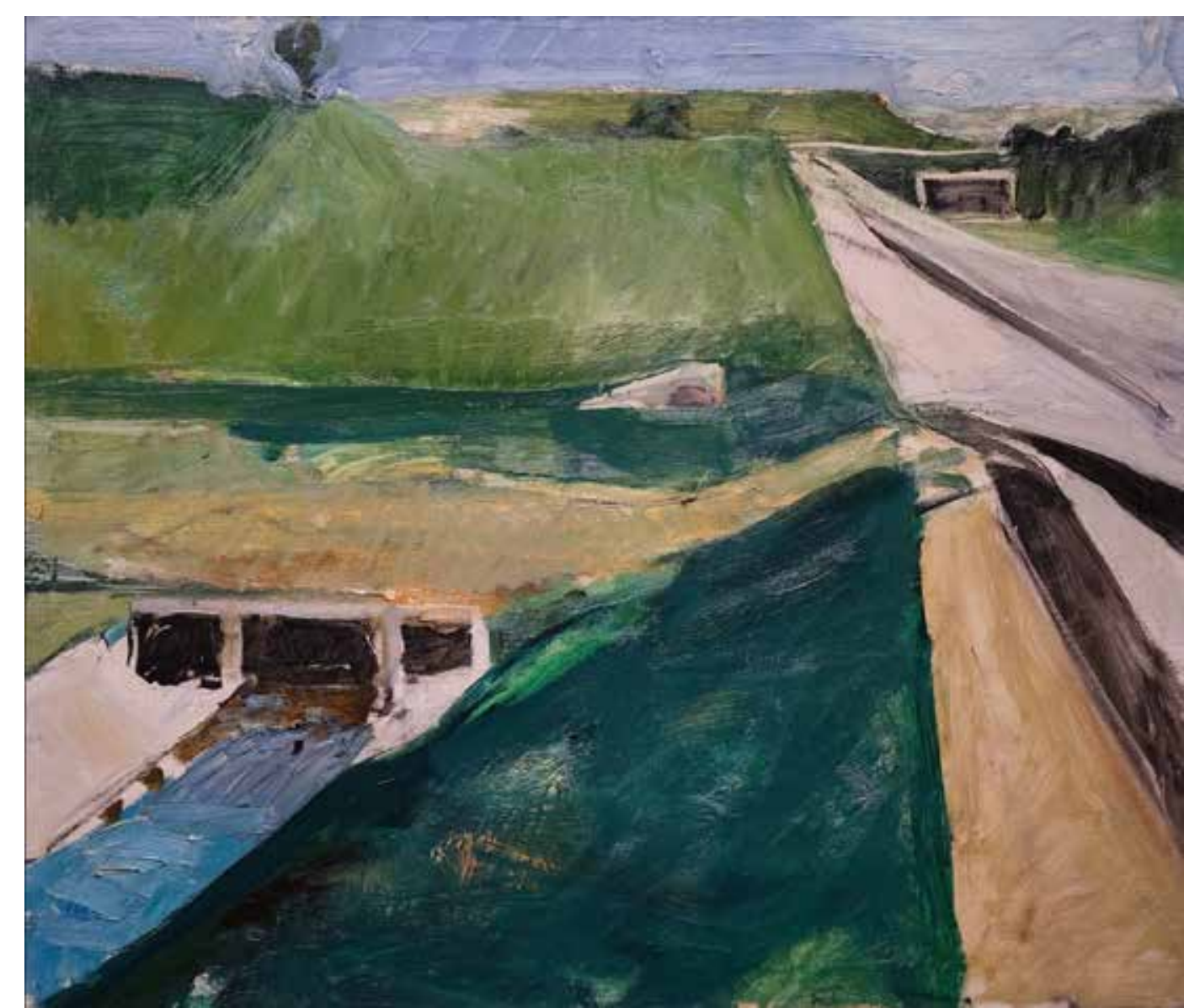

mente "restrita" de cores "naturalistas". A paisagem-natureza das cidades parece resultar em quadros sobrecarregados de verdes, cinzas e marrons, que parecem cromaticamente óbvios e pouco frutíferos aos ideais da pintura moderna. A estranha interação entre o verde das folhas, o azul do céu, e o amarelo da luz solar, uma vez que a primeira cor é resultante da mistura das outras duas, é uma "pedra no sapato" do pintor, que não pode recorrer à complementaridade dessas cores, sendo muito difícil usá-las de modo não mer- 
Ao lado [imagem 79], Richard Diebenkorn, Seawall, 1957. óleo s/ tela, 50.8 × $66 \mathrm{~cm}$. Fine Arts Museums of San Francisco.

Fonte:https://www.wikiart.org/en/richard-diebenkorn/seawall amente ilustrativo, resultando em cores localizadas, sem uma atmosfera que as unifique. A maneira como Diebenkorn o realiza em suas pinturas do final dos anos 1950 demonstra uma maestria tal, que as torna singulares em meio a um grande contingente de tentativas pouco expressivas de se apreender de modo "naturalista” as cores da natureza urbana.

É possível que parte do sucesso do pintor nessa empreitada se deva ao modo como setoriza espacialmente a predominância de cada uma destas cores, que são unificadas por uma camada de cor marrom-avermelhada subjacente, como faziam os pintores paisagistas da tradição clássica. Este modo de construir a cor nas pinturas, como podemos verificar numa análise cronológica da evolução de suas pinturas, é fruto de toda a sua trajetória de experimentação no expressionismo abstrato, com a especificidade de que este pintor sempre atentou às tradições pictóricas para construir uma pintura nova, destacando-se

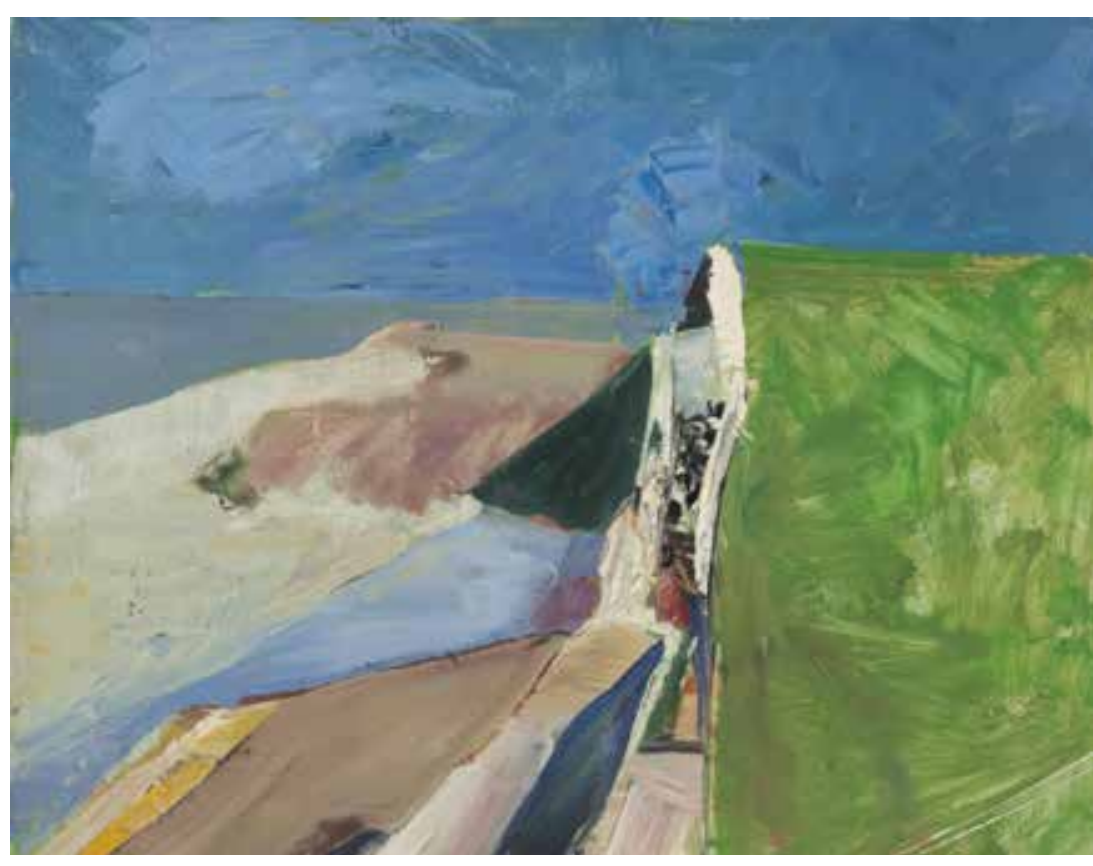




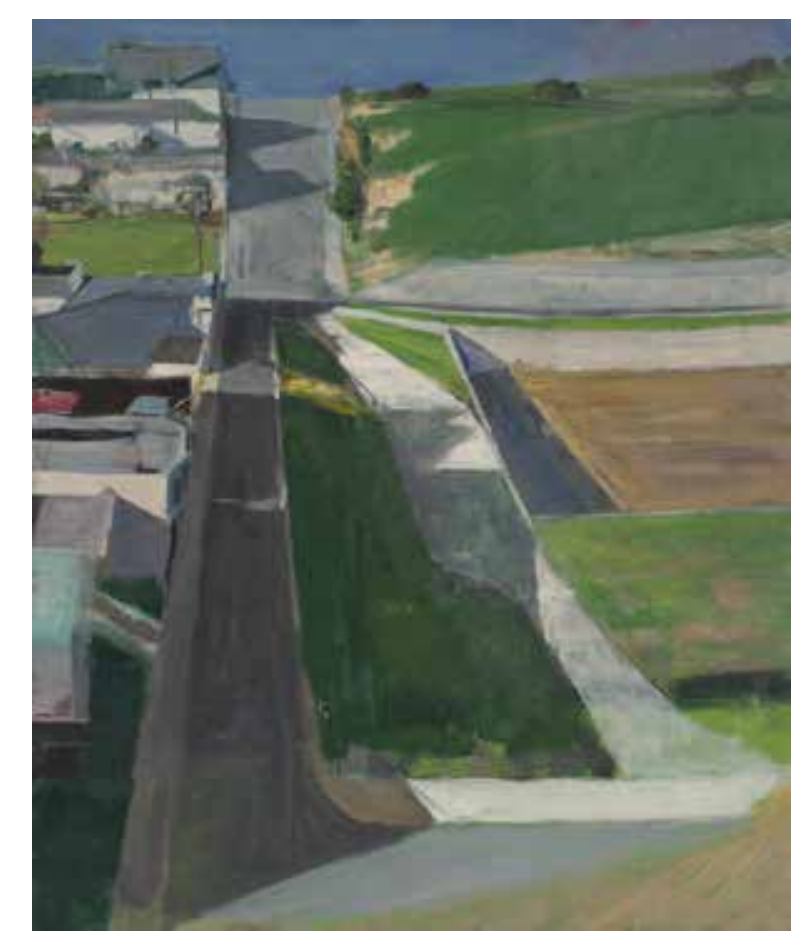

Acima [imagem 80], Richard Diebenkorn, Cityscape I, 1963. óleo s/ tela, $153 \times 128.3 \mathrm{~cm}$. San Francisco Museum of Modern Art, Califórnia. Fonte:https://collection.diebenkorn.org/objects $/ 378 /$ cityscape- 1 ? ctx $=9$ ad5a823-25e1-407eb417-602dda9a14ea\&idx $=0$ do vanguardismo de ruptura de seus contemporâneos. A identidade de cor da paisagem nas ambientações urbanas, assim como sua atmosfera luminosa singular, não poderiam ser construídas de maneira tão convincente e, ao mesmo tempo, livre de esquemas de realismo, senão pelo aprendizado proporcionado pela dialética entre abstração e figuração que caracterizaram a obra de Diebenkorn. A superação de tal dualismo é, talvez, a conquista que proporciona uma sobrevida da paisagem em sua pintura.

Nesta Cityscape I, podemos observar a continuidade, uma década depois, do esquema compositivo presente na sua paisagem de praia Urbana \#5 (Beach Town). Uma rua em perspectiva nos leva à profundidade, ladeada por blocos de cores distribuídos paralelamente em linhas horizontais. A rua é,portanto, o eixo central em um esquema geral claramente ordenado, que nos coloca uma divisão de três planos horizontais; as casas à esquerda, a rua e a área verde sombreada ao centro os loteamentos vazios e áreas verdes à direita. A harmonização do movimento compositivo é visível, por exemplo, no equilíbrio entre linhas diagonais paralelas no plano mais próximo e no plano superior, marcado por uma forte linha horizontal que divide a área de cor verde intensa da área alaranjada, à direita do quadro.

A composição cromática engenhosa cria um jogo de contrastes paralelos entre o amarelo esverdeado em primeiro plano e o céu azul, nas faixas superior e inferior da tela, inserindo uma grande área de cor terrosa alaranjada no plano médio, que atua como cor complementar ao azul do céu ao fundo. Esta tríade de faixas contrapõe-se ao predomínio de áreas verdes no quadro, que se articulam entre os brancos e acinzentados nas áreas sombreadas e iluminadas do eixo vertical central da tela. Com esta composição, o pintor cria um esquema composicional de blocos de cor e luz separados por faixas brancas e acinzentadas de luminosidade. Os valores cromáticos estão setorizados, mas isso não resulta um desenho rígido; pelo contrário, há fluidez e naturalidade no arranjo, construindo um 


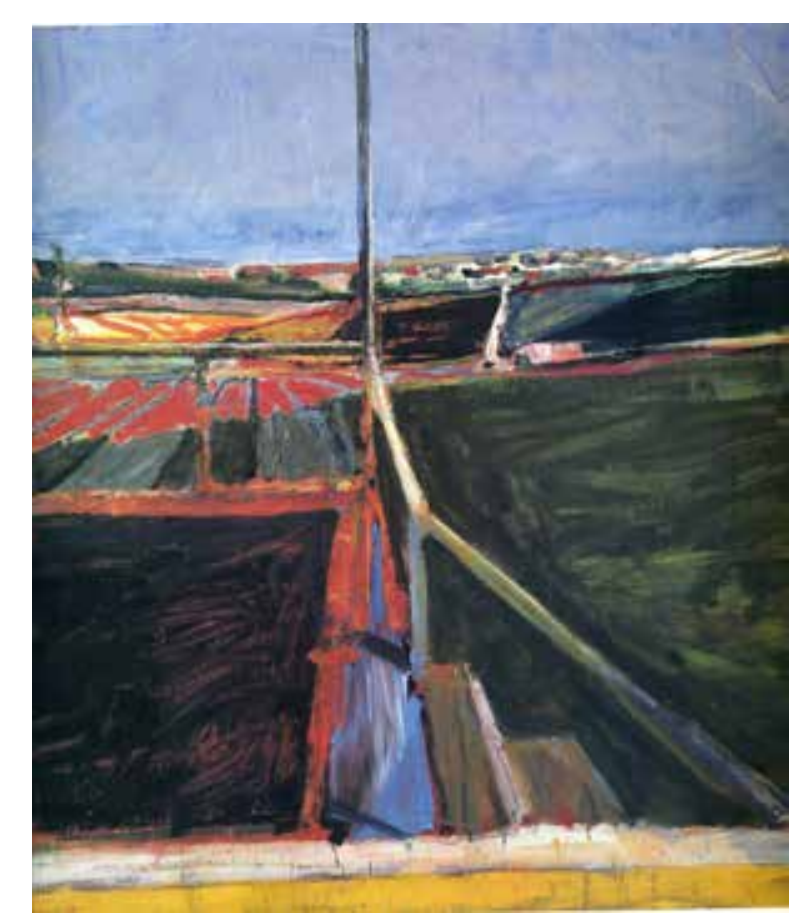

Acima [imagem 81], Richard Diebenkorn, View from the Porch, 1958. Óleo s/ tela, 177.8 x 167.6 $\mathrm{cm}$. Diebenkorn Foundation, Berkeley.

Fonte:https://collection.diebenkorn.org/objects $/ 277 /$ view-from-the-porch?ctx $=47 \mathrm{e} 100 \mathrm{~b} 8$ cd95-4337-a47c-b56b344b429d\&idx=3 desenho de um realismo convincente, sem que o tratamento pictórico o faça de um modo convencional.

A fatura agressiva e brutal característica da action painting dos expressionistas abstratos cria uma representação visual da paisagem de grande verossimilhança e realismo pela vivacidade dos contrastes de luz e sombra e pela luminosidade geral, sem que o pintor tenha que se ater a qualquer minúcia de detalhamento dos objetos que compõem a cena. Como em quase todas as obras de Diebenkorn, uma tensão geral resulta do peso de seu pincel, que unifica expressivamente o quadro, neutralizando o rigor compositivo em um modo fibrilante de ver as formas do mundo: as superfícies estão em constante agitação e as linhas de força sutilmente encurvadas proporcionam uma sensação visual de expansão e retração dos planos, de modo que nada parece estático ou cristalizado. Diebenkorn desenvolveu um olhar que busca, como os impressionistas, a vibração viva do modo de aparecer da luz, mas o executa sem o peso da busca científica pelo brilho do instante; ele cria uma outra luz natural segundo sua invenção e seu imaginário, dotada de grande leveza e vivacidade, sem que a construção desta luz tenda ao atomismo da pincelada impressionista, levada ao limite por Seurat.

O elemento narrativo nas paisagens de Diebenkorn carrega uma temporalidade de difícil classificação. Não é fácil dizer em que medida elas comunicam mais a permanência e a duração, do que um lampejo de visão; a luz parece mover-se junto às sombras, assim como se traduz nos índices do próprio fazer processual da pintura, os pentimenti, que nos dão a sensação de que a imagem continua a ser pintada à medida em que dela nos aproximamos, num processo de construção da paisagem que se deixa ver e que põe a ver sua continuidade. Suas paisagens, aparentemente ordenadas e geometrizadas, dão a ver as coisas como organismos cuja pele vibra em sutil convulsão. Se é possível traçar um paralelo com a física, a poética de Diebenkorn propõe uma luz que nos irradia os olhos mais 


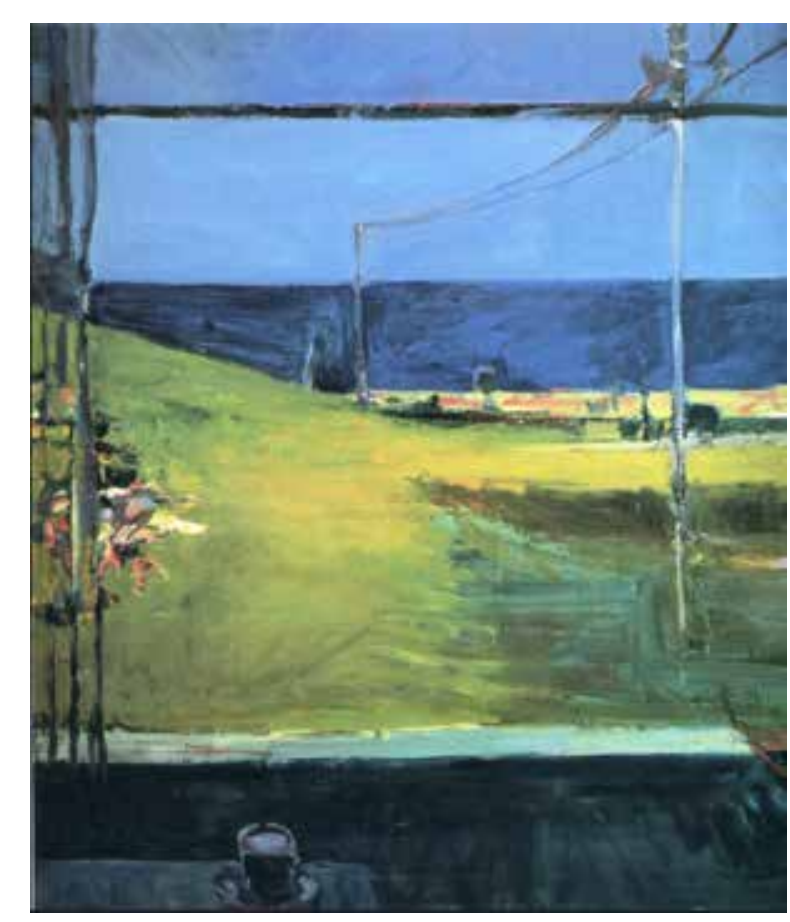

Acima [imagem 82], Richard Diebenkorn, Ocean from a window. 1959. Óleo s/ tela. 177.8 x 162.6 $\mathrm{cm}$. Diebenkorn Foundation, Berkeley.

Fonte:https://collection.diebenkorn.org/objects/267/ocean-from-a-window?ctx $=\mathrm{a} 0076 \mathrm{f} 22$ 637b-4af6-a45a-bbe8ef152055\&idx=2 como ondulatória do que como partícula - o modo impressionista de produzir a sensação luminosa.

Assim como em outros pintores de paisagem cuja vocação é a da ordenação do espaço, as paisagens da fase figurativa de Diebenkorn possuem um aspecto cênico, um "palco" em primeiro plano, sobre o qual vemos alguma figura humana ou objeto, cujo tratamento pictórico não deixa que a personagem se individualize de maneira dramática; são figuras sólidas, mudas, contemplativas como as de Seurat, que não se destacam da paisagem, integrando-a. As figuras costumam sugerir uma certa melancolia, sob um invólucro estático, de uma frieza solitária, como as figuras de Hopper, mas com um menor apelo sentimental, pois elas são ainda mais herméticas, menos eloquentes que as do seu predecessor. Como pintor que se dirige sempre à história da pintura, a influência de Hopper se funde à referência simultânea às janelas de Bonnard e Matisse, reafirmando-se na recorrente presença da janela em primeiro plano, que recorta como moldura a paisagem para o exterior.

Nesse caso, as janelas cumprem a função de bastidores, em paralelo aos terraços voltados à paisagem que servem de proscênio, como na imagem seguinte [83]. Na imagem da página seguinte [84], pela perspectiva "acelerada" pelas diagonais de luz e sombra com que Diebenkorn, é como se uma outra paisagem, por meio da luz, se criasseno espaço interior, conferindo grande profundidade à cena interna.

À medida que avançam os anos 1960, as paisagens de Diebenkorn passam a ganhar contornos cada vez mais definidos, rumo a uma geometrização progressivamente abstratizante. A fatura perde algo de seu expressionismo, a pincelada passa a ser menos agressiva, e vemos paisagens cada vez mais dominadas por uma unidade compositiva intelectual. Após mais de uma década voltado para uma pintura mais representacional e atenta à expressividade da percepção do espaço e da sensação de luz, o caráter construtivo 
Ao lado [imagem 83], Richard Diebenkorn, Woman on a Porch, 1958. Óleo s/ tela. 182.9 x $182.9 \mathrm{~cm}$. New Orleans Museum of Art.

Fonte:https://collection.diebenkorn.org/objects/248/woman-on-a-porch?ctx=c24de4d09db4-4e0b-853e-ccd1e9f3758e\&idx=1

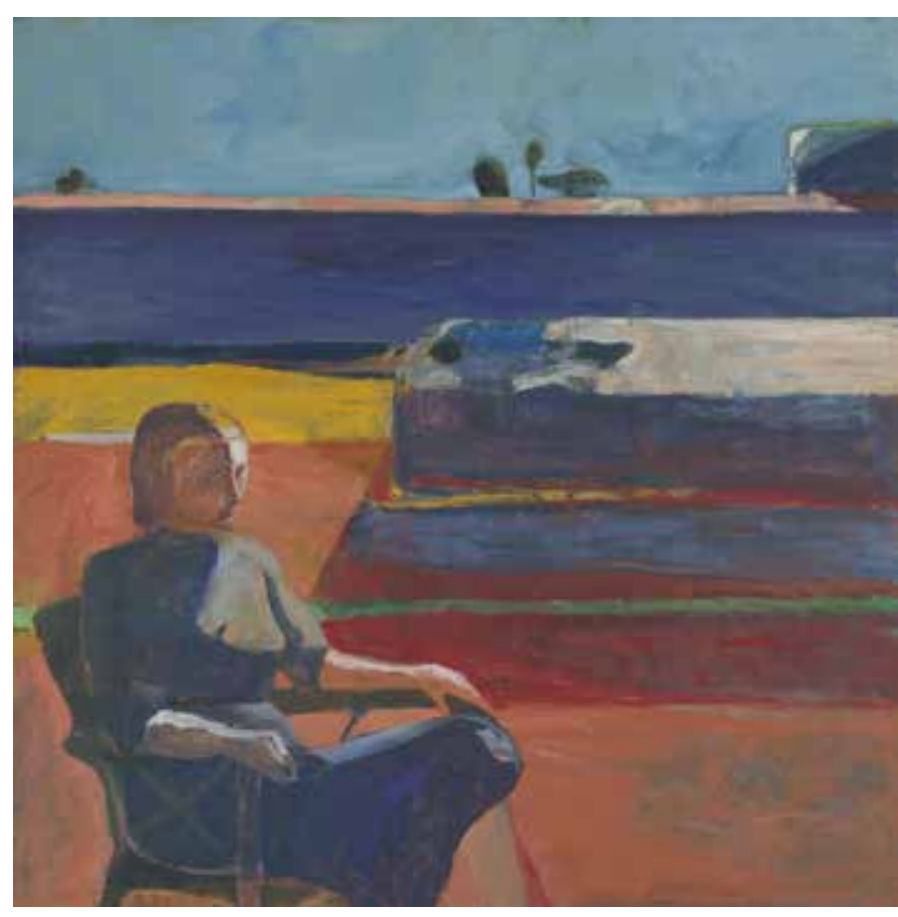

e cromático de sua pintura se impõe, indicando uma expressão madura, de um pintor cujos ânimos menos agitados encontram na pintura a busca de uma identidade singular cada vez mais sintética e rigorosa. Diebenkorn tem uma trajetória sobretudo coerente ao longo de sua carreira, em que é possível notar um desenvolvimento que se orienta sempre em busca de um mesmo princípio visual, e sua última fase, de um abstracionismo puro e sem concessões, não deixa de conter a essência paisagística e o desejo pela organização de espaços mentais inspirados nas cores, luzes e formas do mundo visto. É como se, durante uma década, o pintor estivesse estudando e experimentando, pela figuração do mundo, uma linguagem de formas abstratas cujo vocabulário só se poderia traduzir da visão exterior para a visão interior. Suas últimas paisagens figurativas já transmitem uma 
Ao lado [imagem 84], Richard Diebenkorn, Interior with View of Ocean, 1957. Óleo s/ tela, $125.7 \times 147 \mathrm{~cm}$

Phillips Collection, Washington DC.

Fonte:https://www.wikiart.org/en/richard-diebenkorn/interior-with-view-of-ocean

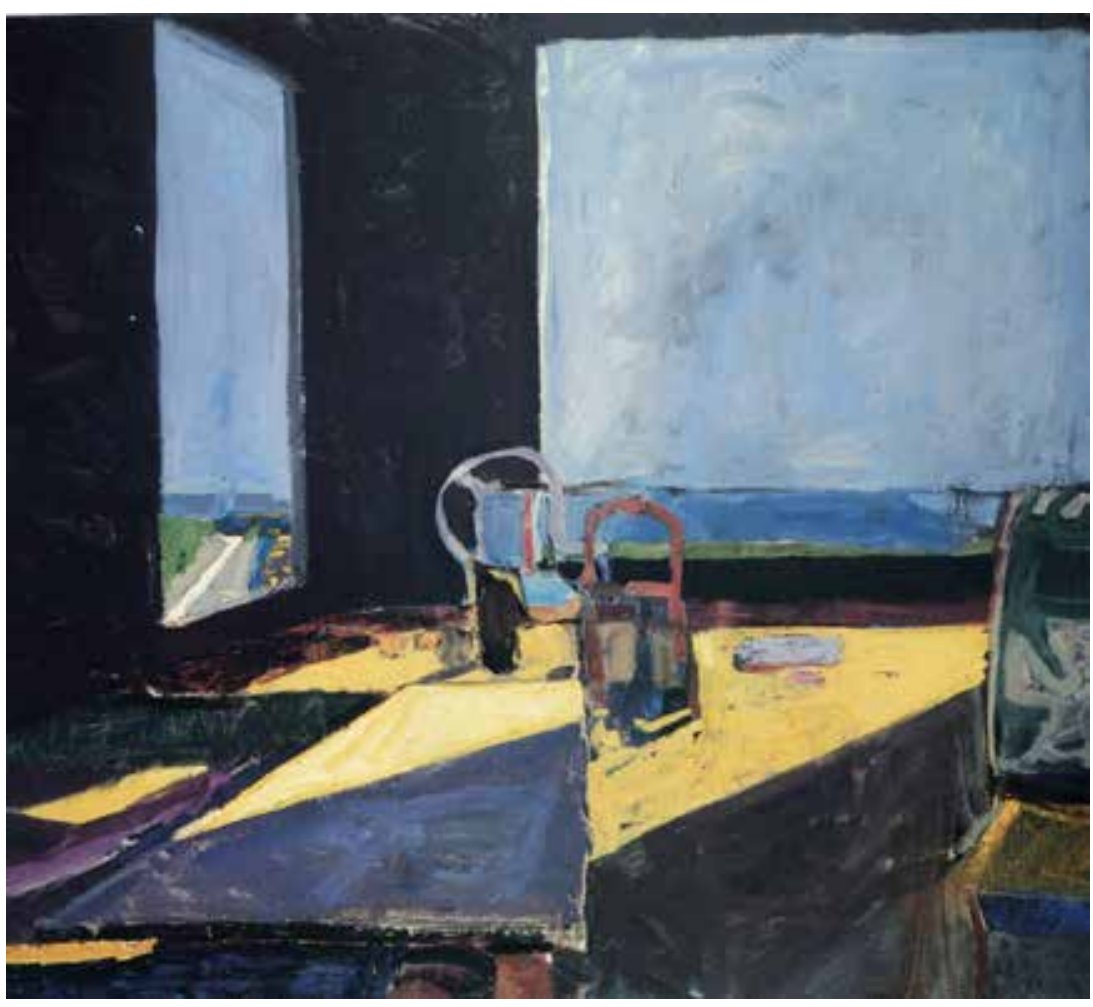

solenidade e um silêncio que não mais busca a animação e o frêmito da luz, mas sim uma ordem cromática e composicional, na decomposição da paisagem em blocos e faixas de cor cada vez mais sutis em seus matizes. O espectro de tonalidades tende a uma gama cada vez maior, com menos cores puras e mais cores pasteis, numa pesquisa que força as cores até seus limites, como veremos na sua última fase.

As formas retilíneas da cidade colocam-se cada vez mais como unidade básica de sua pintura, e, mais uma vez, esta transformação da linguagem coincide com a mudança do pintor para uma nova localidade, a cidade de Santa Monica. A série de pinturas de 


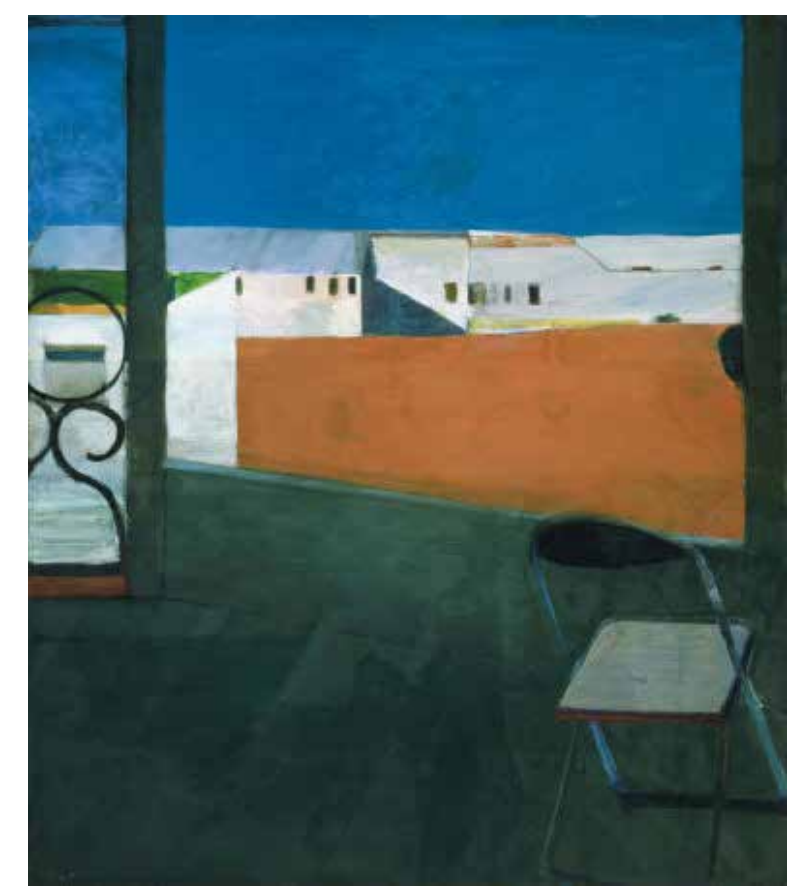

Acima [imagem 85], Richard Diebenkorn, Window, 1967. Óleo e grafite s/tela, $233.7 \times 203.2 \mathrm{~cm}$. Stanford University

Fonte:https://customprints.sfmoma.org/detail/465961/diebenkorn-window-1967
Ocean Park, que consagrou o pintor e perdurou até o final dos anos 1980, quando ele passa a dedicar-se somente à gravura, já não possuindo condições de saúde para pintar suas grandes telas a óleo.

A fase final de Diebenkorn sinaliza um retorno intimista do artista à invenção de espaços partindo da referência à vista da janela de seu ateliê. A investigação, que se inicia com a representação abstratizante de uma janela semi-aberta para a paisagem externa se desdobra, aos poucos, em um extenso estudo de composição em que há quase sempre um estrato de espaço interno com uma janela aberta para o horizonte em uma das laterais da porção superior do quadro. Desse esquema fundamental, cuja referência a Matisse não poderia ser mais evidente, surgem quase duas centenas de pinturas em que paisagens abstratas se constroem com faixas predominantemente horizontais articuladas com linhas e faixas em diagonal, geralmente em relação com a porção do quadro que corresponde à “janela" e ao mundo exterior.

Talvez esta seja uma leitura demasiado simplista e generalista de tais obras, e muitos considerariam um ultraje propor um exame literal de uma obra abstrata de tamanha complexidade. Contudo, uma vez que partimos da hipótese de que é a intenção representacional que gera a poesia visual abstrata deste pintor, não poderíamos seguir outro caminho que não o de procurar ver paisagens nas pinturas de Diebenkorn. Sob essa ótica, a abstração nada mais é que um modo de ser do raciocínio figural, mas que evita as associações sígnicas da forma a um assunto ou motivo: mas, ao que nos indica a obra de Diebenkorn, tal exigência pode tornar infrutífera a necessidade que têm os artistas de comunicar e expressar sua experiência visual do mundo.

Nestas últimas obras de Diebenkorn, podemos indicar a façanha, arduamente conquistada, de produzir paisagens em que se transcende uma oposição entre interioridade e exterioridade: o olhar do pintor vê, de dentro de seu estúdio, das suas paredes, 
Ao lado [imagem 86], Richard Diebenkorn, Ocean Park \#32. 1970. Óleo s/ tela, 236.2 x 205.7

Fonte:https://collection.diebenkorn.org/objects $/ 450 /$ ocean-park-32?ctx $=2 \mathrm{~d} 08483 \mathrm{e}-\mathrm{d} 65 \mathrm{~b}$ $4 \mathrm{fe} 4-97 \mathrm{~cd}-\mathrm{e} 56 \mathrm{cb} 22 \mathrm{f} 2 \mathrm{~cd} 9 \& \mathrm{id} \mathrm{x}=0$

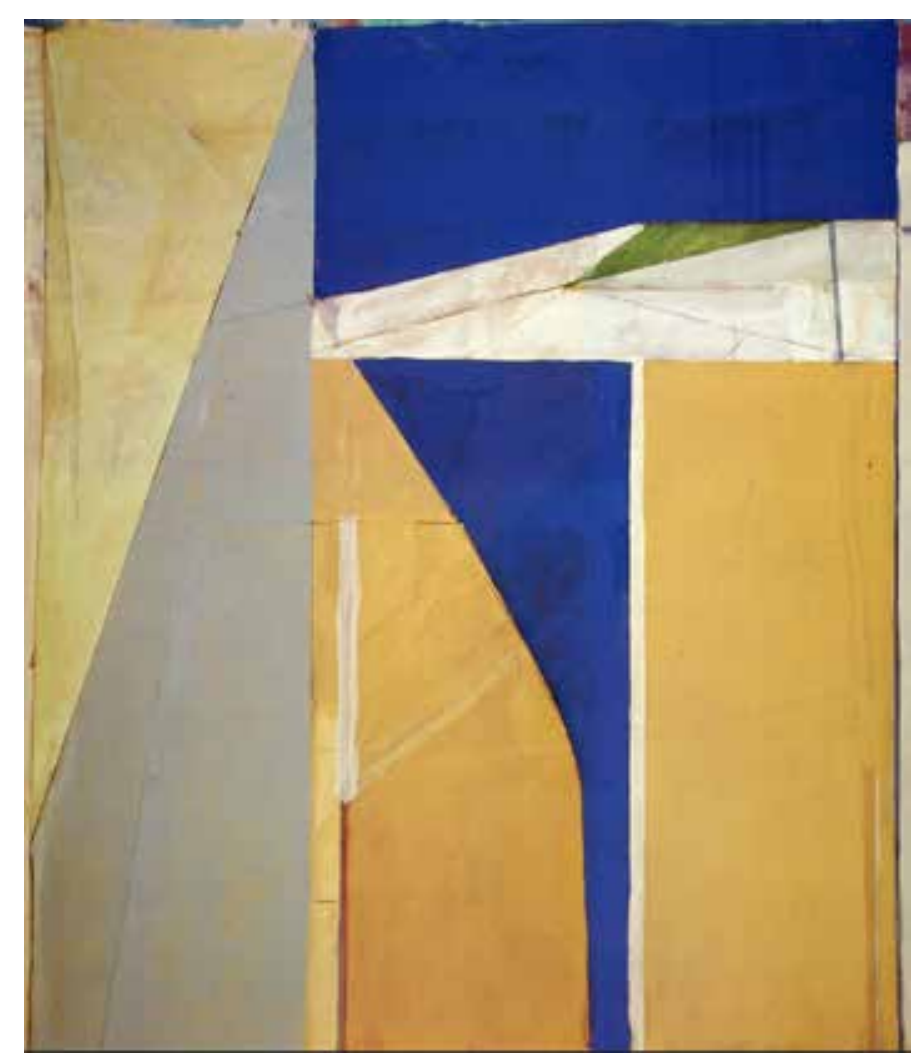

janelas e de suas próprias pinturas, uma espacialidade nova, que se mistura à paisagem e ao horizonte que se vê lá fora. Um recolhimento característico ao avanço da idade proporcionou ao artista o aprofundamento da consciência de sua experiência poética em direção aos seus fundamentos e princípios centrais. A título de comparação, acima à direita, temos um desenho de observação em papel da vista que o artista de fato tinha de seu estúdio em Ocean Park, à mesma época.

Na imagem que segue, vemos o que poderia ser uma “depuração” de suas paisagens 
À esquerda [imagem 87], Richard Diebenkorn, Studio Window- Ocean Park, 1970, óleo s/ tela 213.4 x $182.9 \mathrm{~cm}$. Diebenkorn Foundation, Berkeley.

Fonte:https://collection.diebenkorn.org/objects/455/ studio-window--ocean-park?ctx=75fff209-62df-4882a5f3-1f5a097b190d\&idx=5

À direita [imagem 88], Richard Diebenkorn, Untitled (View from the Studio), 1969, guache, carvão e nanquim s/ papel $43.2 \times 34.9 \mathrm{~cm}$. Diebenkorn Foundation, Berkeley

Fonte:https://collection.diebenkorn.org/objects/814/ untitled-view-from-studio-ocean-park?ctx=81e16b23$3 \mathrm{ff} 7-430 \mathrm{f}-\mathrm{b} 3 \mathrm{f2}-2 \mathrm{fc} 84 \mathrm{c} 2848978 \mathrm{idx}=5$ da década de 1960, em que uma varanda ou terraço em primeiro plano convidam o olhar a percorrer o território urbano em busca da distância, num percurso de formas que evocam o imaginário da cidade construída, da vegetação urbana, dos arruamentos, até que se chegue a algo que poderia ser o mar, o triângulo invertido em azul marinho, no canto superior esquerdo da tela. Sobre ele, uma fina faixa de céu azul, que habita grande parte das paisagens de Diebenkorn, é encimada por uma linha preta,que poderia ser simplesmente a alusão ao limite superior de sua janela.

A trajetória deste artista nos coloca diante da evidência de que a paisagem esteve sempre no centro de sua poética, ainda que o artista evitasse assumir uma adesão declarada à vocação de pintor paisagista. Em tempos de ruptura programática e de vanguardas no campo das artes visuais, Diebenkorn, foi declaradamente um tradicionalista, e não sentia
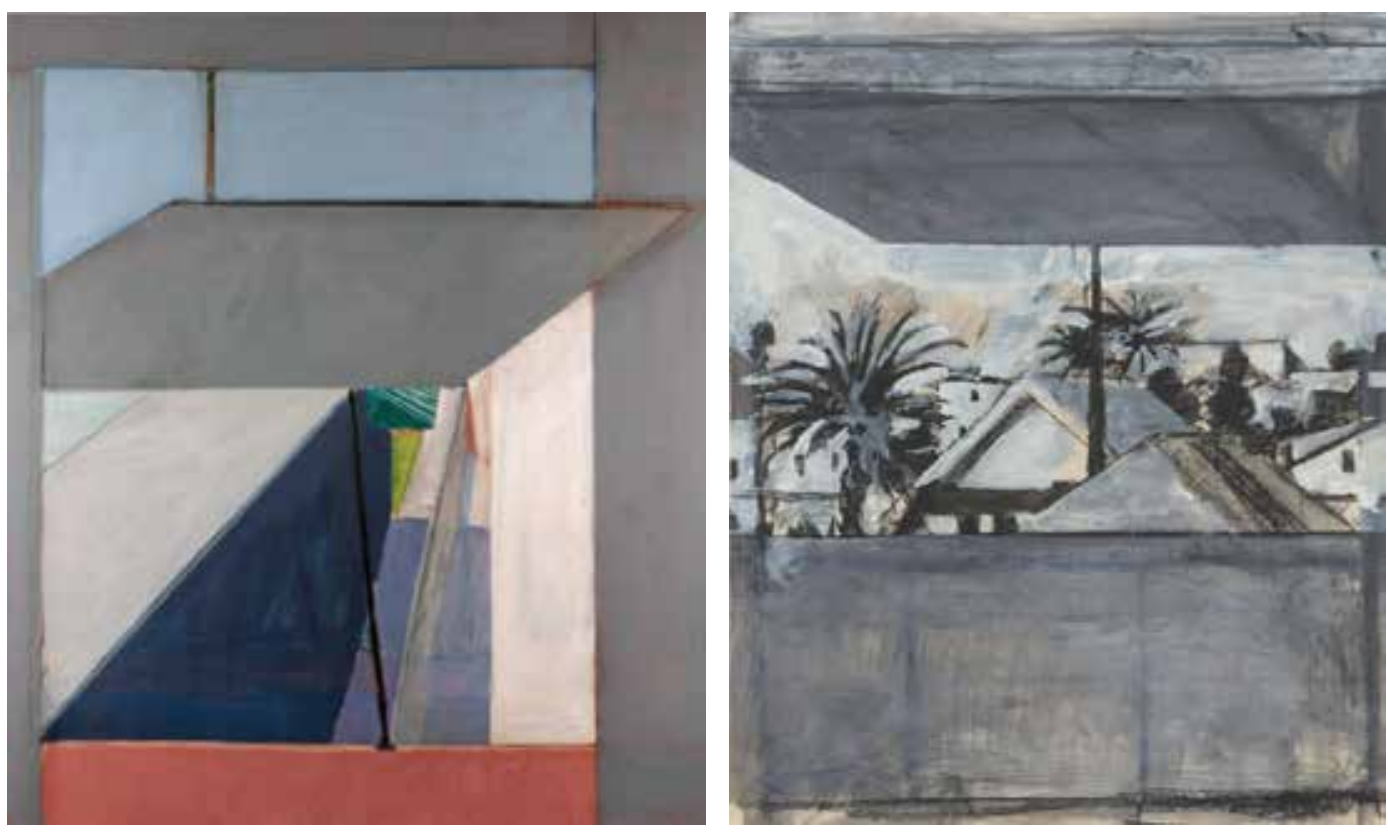
qualquer constrangimento em levar adiante as conquistas de gerações de pintores anteriores à sua. Isso em nada diluiu o caráter inovador de seu olhar, assim como fez com que seu desejo pela paisagem transparecesse de forma não cristalizada e temática em seu trabalho, mas guardando uma liberdade sugestiva e uma universalidade que permitiu a seu estilo transitar por entre diferentes registros de uma mesma intenção: a de manter-se fiel, como quer Merleau-Ponty, ao seu "enlace com o mundo".

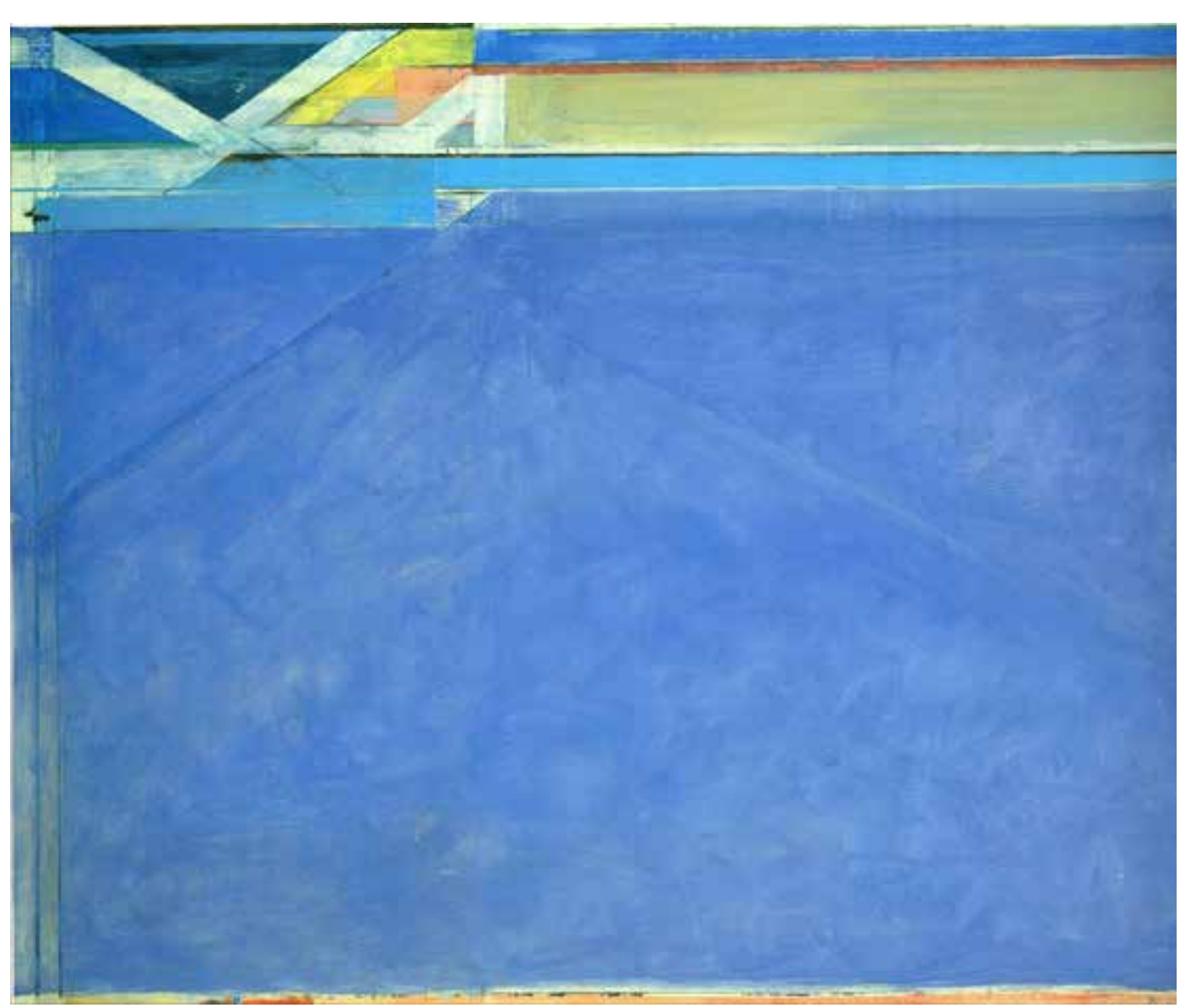
Park \#129,1984. Óleo s/ tela 167.6 × $205.7 \mathrm{~cm}$ https://collection.diebenkorn.org/objects/563/ ocean-park-129?ctx $=04081$ f64-8464-49b4-a9dae165f43bc069\&idx $=75$ 
4.3

\section{Em direção às paisagens contemporâneas}

A imersão na obra de Diebenkorn intencionou, além de apontar em sua linguagem aspectos formais de um diálogo com as paisagens do rio Pinheiros, indicar um possível desdobramento da historiografia proposta por Kenneth Clark com seu "retorno à ordem" na paisagem moderna. Nesse sentido, propusemos a continuidade dessa narrativa sobre a representação da paisagem com um episódio em que a relação poética com a paisagem passa a ser encampada por uma atitude artística que tende, historicamente, à da contemporaneidade. A paisagem, então, já não é refém de pretensões científicas, românticas ou heróicas em relação à realidade da experiência, mas está imbuída de uma fruição mais livre do caldo de formas, signos, sensações e memórias do que vem a ser uma experiência paisagística do mundo.

Mas, como pretendemos demonstrar, a sobrevivência da paisagem como representação bidimensional, seja pictórica ou gráfica, foi questionada e criticada nas últimas décadas do século XX, de tal modo que a problemática da abstração versus figuração deixou de ser uma questão para a arte dita contemporânea.

Diante do espraiamento conceitual e da consequente dissolução semântica da acepção de "paisagem" a partir do século XX, uma paisagem do mundo urbano contemporâneo nos parece algo complexo de se ver, de se definir e de se representar. Some-se a isso uma tendência homogeneizante e uniformizadora da urbanidade globalizada, que solicita ao olhar estético um antídoto à indiferenciação nas paisagens contemporâneas, que não mais podem ser apreendidas somente por um olhar pitoresco. Sobre esse aspecto das paisagens contemporâneas, Alves" afirma que "[..] seu interesse atualmente escapa à formalização de modelos pictóricos tradicionalmente estabelecidos e a valores associados ao idílio, ao sublime e ao belo natural.“ (ALVES, 2001, p. 67)

A questão da paisagem na arte passa necessariamente por uma revisão no final do século XX, e o rebatimento da filosofia contemporânea na arte conceitual imprime suas 
marcas sobre os novos olhares para a paisagem. Diante desse debate, as paisagens de um artista como Diebenkorn, por mais que sejam autônomas em relação ao modernismo, que insiram a paisagem-natureza no meio urbano e que, historicamente, se situem no período dito contemporâneo, não correspondem ao ideal da arte contemporânea que se reporta à paisagem, e seriam consideradas por muitos um olhar paisagístico retrógrado. Em grande medida, isso ocorre por sua natureza pictórica e, de certa forma, representacional. No entanto, o mérito dessa crítica é pouco relevante aos nossos objetivos. Nos interessa, contudo, a constatação de que a paisagem se manifesta em meio ao contexto das contemporâneo de modo a colocar novos assuntos e estruturas e visuais, e examinar se isso se afirma em nossa produção de paisagens do rio Pinheiros.

Nas páginas que seguem, em direção a um desfecho de nossa narrativa histórica, introduzimos aspectos dessa nova arte das paisagens, dirigindo-nos ao contexto da arte de hoje, em relação situaremos a pintura de paisagens com o exemplo do pintor brasileiro Paulo Pasta.

Em seu "Paisagens Urbanas", Nelson Brissac-Peixoto, ao nos introduzir ao movimento histórico de alargamento conceitual do espaço antes circunscrito ao recorte da janela, desdobrado do interior da própria noção pictórica tradicional de paisagem, nos demonstra que "A paisagem então deixa de ser aquilo que se oferece lá ao fundo para se converter no campo, plano e extenso, em que se articulam todas as coisas: uma grade."(PEIXOTO, 1996, p. 10).É da cidade que ele fala, na medida em que não podemos delimitar sua extensão, ela nos escapa.

"Horizonte saturado de inscrições, depósito em que se acumulam vestígios arqueológicos, antigos monumentos, traços de memória e o imaginário criado pela arte contemporânea. Esse cruzamento entre diferentes espaços e tempos, entre diversos suportes e tipos de imagem, é que constitui a paisagem das cidades.

O olhar hoje é um embate com uma superfície que não se deixa perpassar. Ci- 
Por isso, para Peixoto, a crise do moderno levou a paisagem na arte à tarefa de lidar com a questão do entrelaçamento entre linguagens e com a da relação da obra com seu entorno. Seu argumento é o de que a a arte teria hoje a função de construir novas imagens da cidade, imagens que viessem a fazer parte, elas mesmas, da própria paisagem urbana (1996, p. 13), e que, portanto, é difícil um olhar paisagista "construído para horizontes passados". No entanto, ele, ainda assim, não exclui a pintura dessa função artística.

A dinâmica de transformação no debate paisagístico imporia à paisagem como criação pictórica um impasse; e assim, talvez lhe impusesse também uma nova função estética diante da produção de conhecimento sobre a paisagem e o fazer paisagístico. Por outro lado, as novas formas de arte da paisagem distanciavam-se cada vez mais dos problemas da pintura. Em relação aos processos de artializaçã $0^{10} \mathrm{da}$ natureza, o advento da imagem fotográfica e sua massificação deslocaram o debate acadêmico sobre a experiência sensível da paisagem, na segunda metade do século XX, para níveis do discurso estético predominantemente conceituais, centrados no movimento e na estetização dos deslocamentos e do caminhar. Tais deslocamentos, por si só, configurariam uma forma de escritura do corpo sensível sobre o território, em um alargamento crítico da ideia de representar a paisagem.

Foi significativo o papel que tais poéticas do caminhar e a land art tiveram em relativizar o caráter contemplativo, dominador, idealizado e passivo que a tradição da pintura de paisagem na arte impõe; entretanto, reivindicar radicalmente a relação de presença ativa, operante e atual na paisagem como algo específico dela, como uma descoberta exclusiva dessa nova arte da paisagem, como se ela já não constituísse parte fundamental do trabalho de muitos dos pintores tradicionais ou fotógrafos de paisagens, acarreta uma 
10. Roger, Alain (1997) apud Alves 2001, 67. “[...] para ser paisagem, um território deveria ter uma apreciação estética favorável. É o processo que Alain Roger (1997) define como artialização: conquistar os territórios para a paisagem através de um processo de artialização, ou seja de transformar o espaço visível através de uma apreciação estética positiva." problemática iconoclastia conceitual, anti-representacional.

Protagonizada por artistas como Robert Smithson, Richard Long e Hamish Fulton, a negação da linguagem visual de representação na arte paisagística, na qual preponderam poéticas do caminhar e a land art, revela, no entanto, certo caráter paradoxal e contingente, uma vez que imagens fotográficas, desenhos e cartografias são ainda as principais referências e meios de difusão dessas obras de arte, quando não o seu fim material implícito. Considere-se também que, além disso, o desenho artístico, no caso da land art de Smithson, Christo e Jeanne-Claude, entre outros, constitui papel fundamental em sua concepção e projeto. A veiculação imagética de tais obras demonstra que não resulta delas, de fato, uma ruptura estética radical, uma tabula rasa da ideia artística de paisagem proveniente da pintura, e que, em grande medida, os artistas da land art ainda concebem a experiência da paisagem como evento deslocado da realidade das ambientações urbanas.

Os pressupostos conceituais da land art propõem uma ruptura com a representação da paisagem, fazendo da paisagem real seu plano poético, assumindo como verdade absoluta que a verdadeira experiência da paisagem não se imiscui de qualquer caráter representacional. Contudo, nosso intuito é refletir sobre a paisagem enquanto fenômeno da linguagem e verificar que a dualidade oposta entre experiência e representação, e seus desdobramentos nas "artes da paisagem" são construções históricas contextualizadas, que não se sustentam se analisadas com rigor as suas manifestações. Nesse sentido, compreende-se que, como forma de contato, o caminhar estético sobre a paisagem seja, de certa forma, autoevidente, momento anterior incontornável, como um tipo de pré-requisito à singularidade da experiência paisagística. A qualidade estética dos registros das obras da Land Art evidenciam que a produção de imagens ainda constitui a efetivação dessa experiência enquanto linguagem. E que ela não pode prescindir de um esforço de formalização para que se faça comunicável, para que se constitua em expressão, estruturando percepções e 
povoando o imaginário paisagístico.

\section{$O$ percurso às margens do rio Passaic}

A preponderância de Robert Smithson em relação aos diversos aspectos e manifestações da land art se deve, junto ao seu pioneirismo, à profundidade e competência artísticas com que coloca a questão do caminhar e do percurso, sem recorrer somente a discursos vazios e negativos de ruptura, mas propondo um novo olhar para a paisagem urbana e produzindo textos de alto valor literário e sensibilidade. A ressonância de suas ideias nos anos 1960 foi tal que, até os dias de hoje, os artistas interessados na paisagem das ambientações urbanas bebem na fonte de seus escritos. Segundo Careri ${ }^{11}$, é com Smithson que a inovação protagonizada na viagem de Tony Smith vai além do aspecto de escultura minimalista (o objeto) e o percurso (o não-objeto): é pensada em termos de uma nova concepção de paisagem, associada a uma espacialidade prolongada, que envolve a estrada, em direção à ideia de território ou extensão.

No contexto da publicação do texto de Tony Smith na Artforum em 1967, já se colocava a centralidade e vigor teórico de Smithson, endossando e desenvolvendo as idéias de Smith. Introduzindo uma nova abordagem da ideia de paisagem, de forte viés conceitual, Smithson sugere que os "[...]lugares remotos, como Pine Barrens, em Nova Jersey, ou as planícies congeladas do Pólo Norte e do Pólo Sul, [...] podem ser reconsideradas como formas de arte que poderiam usar o território atual como medium". A abordagem de Smithson é a de que a paisagem ou o espaço podem ser lidos como texto, e o naturalismo “[...]é substituído por um sentido não-objetivo do espaço. A paisagem começa então a mostrar-se mais como uma carta em três dimensões do que como um jardim rústico" ${ }^{12}$

A publicação de The Monuments of Passaic, um dos trabalhos mais célebres de 


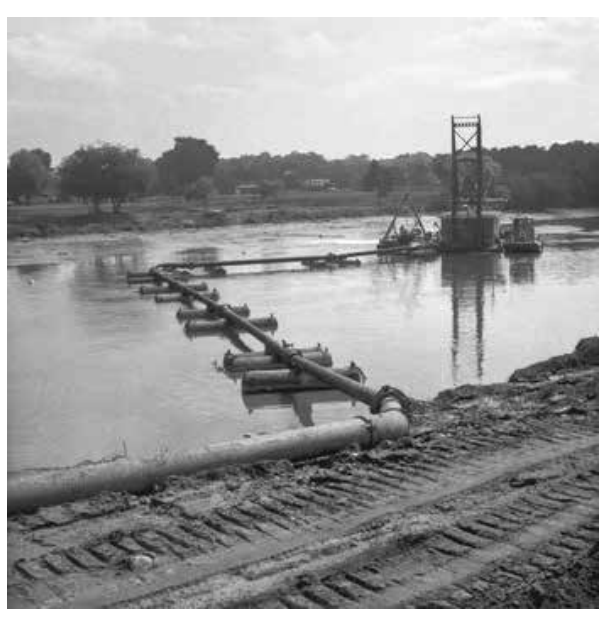

Acima [imagem 90], Robert Smithson - The Great Pipes Monument - 1967.

Fonte:https://www.robertsmithson.com/photoworks/monument-passaic_300.htm)

11. CARERI, Francesco.Walkscapes: o caminhar como prática estética. São Paulo: Editorial Gustavo Gili, 2013.

12. Smithson, R. "Aerial Art," Studio international, fevereiro-abril de 1969, republicado em The Collected Writings, 116
Smithson, em dezembro de 1967, na mesma Artforum, foi acompanhada de uma mostra na galeria de Virginia Dwann, em que foram exibidas 24 fotografias e uma cópia de um mapa da região. Smithson propunha uma ressignificação da área industrial e periférica das margens do rio Passaic, num percurso em que narra a descoberta de uma paisagem povoada por escombros do resíduo industrial, cujo caráter escultórico é revelado por sua sensibilidade estética inovadora. Os "monumentos" resultam de um olhar que empresta das novas descobertas estéticas uma linguagem expressiva singular, em uma atmosfera de atemporalidade resultante da marginalidade e esquecimento ao qual a região estava abandonada.

As imagens do rio Passaic produzidas por Smithson dialogam diretamente com o olhar que guia nossa visão à paisagem do rio Pinheiros, havendo nelas um interesse semelhante à monumentalidade escultórica daquilo que chamamos anteriormente de "figuras", "seres", ou "personagens" que habitam as margens do rio Pinheiros. É claro que Smithson não está interessado especificamente em construir imagens visuais de uma paisagem, e investe sua poética de recursos mais literários e conceituais da representação. Mas a concepção de paisagem que encampa seu empreendimento com o rio Passaic diz muito acerca daquilo que podemos considerar a paisagem nas ambientações urbanas contemporâneas, que, no nosso caso, vem a ser a das margens do rio Pinheiros. Uma mesma teatralidade da ruína urbana, a desolação e a temporalidade esquizofrênica, deslocada, que se apresenta em meio aos escombros que anunciam um território sempre em obras, se vê nitidamente no trabalho de Smithson, o que o reveste de especial interesse à nossa pesquisa.

"Smithson define a viagem como uma odisséia urbana, uma epopéia pseudoturística que celebra como novos monumentos as presenças vivas de um espaço em dissolução, de um lugar que trinta anos depois será chamado não lugar."(CARERI, 2013, p.138) 
Haveria, para Careri, sinais de uma paródia da linguagem dos relatos de viagem do século XIX, ou seja, um componente irônico implícito no ensaio de Smithson, quando ele cita o artista viajante do romantismo, deslocando-o para um cenário oposto ao da ruína turística romana: um cenário da precariedade e degradação das periferias urbanas. Mas, certamente, não é a ironia o maior êxito de seu trabalho, tampouco a originalidade da escolha do tema; de certa forma, a estetização da ruína industrial urbana seria uma atualização do pitoresco ${ }^{13}$ no século XX, e artistas gravadores como Charles Meryon, entre outros, já no século XIX se interessaram por este caráter expressivo da degradação das áreas abandonadas da cidade e suas transformações.

Ao lado [imagem 91], Robert Smithson - The Fountain Monument - Bird`s Eye View - 1967 Fonte:https://www.robertsmithson.com/photoworks/monument-passaic_300.htm)

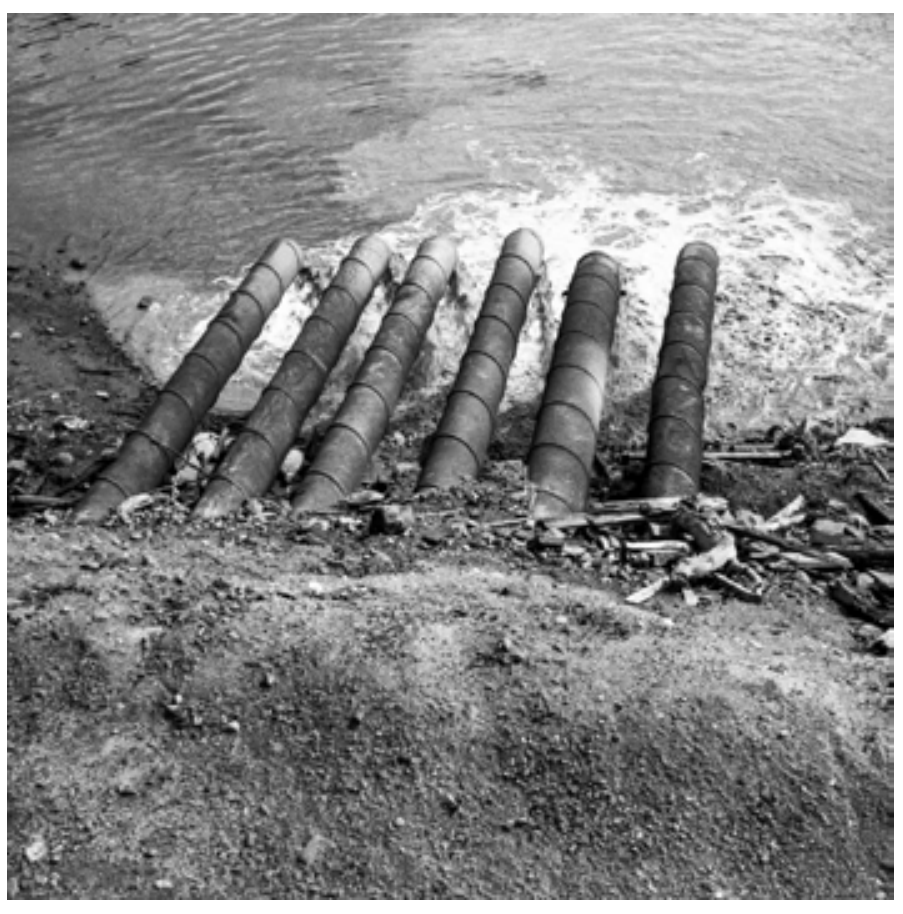




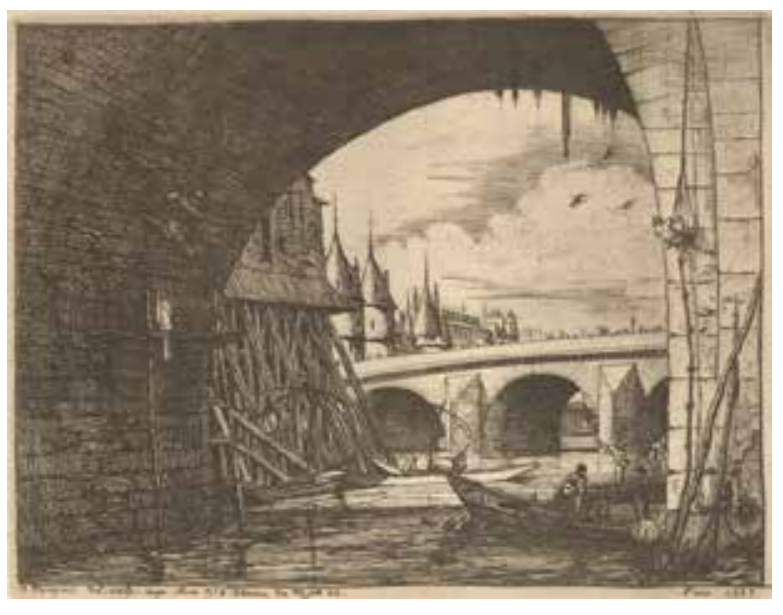

Acima [imagem 92], Charles Meryon, Bomba d'agua de Notre Dame - 1852.

Fonte:https://www.artgallery.nsw.gov.au/collection/works/DO1.1963/)

13. SILVA, Sued F., CRUZ, Luciana S.F., MEDEIROS, Ana E, 2016, "Para Price o pitoresco se dá na singularidade, rusticidade, incerteza, variedade, aspereza, deterioração, fragmentação e no intricado, características que o situam entre o sublime e o belo. Já Ruskin compreende o pitoresco como uma subcategoria do sublime, a Sublimidade Parasitária, consubstanciada pela ação do tempo e por qualidades estéticas acidentais ou externas, "linhas angulares e quebradas, oposições vigorosas de luz e sombra, e cores escuras, profundas, ou fortemente contrastadas".
Há diversos ensaios visuais em séries de gravuras evidenciando um olhar para a marginalidade da ruína urbana, que é diferente da ruína clássica que tanto interessou artistas como Piranesi e John Ruskin; no caso de Meryon, retrata-se Paris em vias de ser reconstruída sob a gestão de Haussmann, e podemos sinalizar um olhar próximo ao dos "monumentos" da precariedade de Smithson.

O grande êxito de Smithson, que o distinguiu de seus colegas britânicos, foi a capacidade de, por meio de uma imaginação estética sensível à materialidade escultórica do objeto industrial, somada a um olhar muito familiarizado com os dispositivos fotográficos e mídias de seu tempo, formalizar uma obra simultaneamente literária, conceitual e visual por meio de uma habilidade discursiva e narrativa notável. Nas palavras do próprio Smithson, temos uma caracterização precisa de suas proposições em relação ao que deveria ser a linguagem da paisagem contemporânea, numa crítica direta ao anacronismo de um olhar pictórico e às utopias e abstrações do modernismo:

\footnotetext{
"Como vemos, o passado do mundo está condicionado pela pintura e escrita. Hoje em dia, nossas percepções e condição social estão determinadas aos filmes, fotografia e televisão.[...] O artista deve sair do isolamento de galerias e museus e proporcionar uma consciência concreta para o presente como ele realmente existe, e não simplesmente apresentar abstrações ou utopias...devíamos começar a desenvolver uma educação artística baseada em relações aos sites específicos. Como vemos as coisas e lugares não é uma preocupação secundária, mas primária." (Smithson apud Vivacqua, 2012,p. 20).
}

A leitura de Careri, contudo, privilegia o êxito relacional e conceitual do Monuments of Passaic. Nesse sentido, ele nos pergunta, retoricamente: "Assim, a obra consiste em ter realizado esse percurso? Ou consiste em ter conduzido outras pessoas ao longo do Passaic River? A obra está nas fotos expostas na galeria ou nas fotos que os 
visitantes tirarão? A resposta é que a obra é todas essas coisas juntas." (2013, p.140)

Trata-se, portanto, de uma interpretação conceitual e relacional de arte, que leva em conta a ideia de obra aberta, como realização total, multidisciplinar que, em potencial, abre margem para infinitos desdobramentos. Contudo, quando descemos ao solo das realizações materiais, em busca de uma caracterização da linguagem da paisagem na arte contemporânea, é necessário nos atermos àquilo que, de fato, foi produzido pelas mãos do artista. E em quais aspectos sua produção, no que se materializa, difere, ou se identifica, dialoga e se contrapõe às produções de outros ditos artistas da paisagem. A vocação literária e a competência teórica de Robert Smithson merecem destaque e, aliadas à consistência de suas proposições escultóricas, fazem dele uma figura singular em relação aos seus colegas da land art. Destaca-se também a sua sensibilidade para o elemento residual e periférico e para a temporalidade anacrônica expressa por ele na condição urbana contemporânea.

O risco que se corre com a negatividade da ideia de que a experiência estética da paisagem não se exprime como linguagem comunicativa, não sendo representável, é o de recairmos num niilismo subjetivista que cultua personalidades artísticas acriticamente. As obras de arte sobre a paisagem, uma vez que se reportam à experiência atual e ao mundo percebido, nos falam de conteúdos que nem são apenas exteriores e objetivos, nem só interiores e subjetivos. Portanto, não podemos nos fiar só em intenções artísticas e crer na singularidade da experiência do artista, sem levar em conta o valor estético daquilo que ele realiza, em termos de linguagem, para que tal experiência se faça comunicável. Uma vez que alguém se coloca como artista, é necessário grande esforço prático para transmitir algo de valor singular da sua experiência, para que outros transformem sua própria experiência a partir do que lhes foi transmitido. É aí que sempre esteve a relacionalidade da arte.

Vale lembrar que os artistas da land art expressaram anseios de transformação na 
linguagem da paisagem historicamente justificados, cujo legado artístico é incontestável, tendo ampliado significativamente as possibilidades de ação do artista paisagista. Colocar novamente em evidência a importância do caminhar e do corpo sensível no espaço era uma necessidade verdadeira da arte naquele determinado momento.

Nosso intuito é relativizar o dualismo que opõe experiência e representação, entre outros desdobramentos dessa oposição: frutos de um momento datado de ruptura, conceitos negativos sobre a impossibilidade da representação confundem e dificultam o reconhecimento e assimilação das contribuições trazidas pelas diversas formas de arte sobre a paisagem. O desenvolvimento artístico da paisagem deve caminhar, sem negar sua própria historicidade, na perspectiva de que, diferentemente da realidade bruta da natureza, solo no qual estamos fincados, a paisagem existe na medida em que se faz, por nós, sensível e comunicável.

Após esta breve descrição do episódio conceitual da paisagem na arte contemporânea, a última etapa de nossa narrativa passa, então, pelo exame de parte da obra de Paulo Pasta, pintor brasileiro contemporâneo e que se filia diretamente à linhagem de Diebenkorn, conhecido por uma obra de caráter construtivo e abstratizante, mas cujo desejo pela paisagem se expressa insistentemente.

Será importante demonstrar em que medida certas contribuições da arte contemporânea foram por ele assimiladas, no sentido de que sua relação com a paisagem se pautará pela busca de uma linguagem e de uma ordem paralela à da natureza, assim como em Diebenkorn e os modernos, e pela construção de espaços mentais em que se reconhece tanto a geografia quanto a tradição artística e as afetividades da memória. 
A recente produção de Paulo Pasta concentra um grande número de paisagens em que as cores da memória afetiva se fundem à invenção e ao registro fotográfico da zona rural paulista. Em exposição realizada no Instituto Figueiredo Ferraz, em Ribeirão Preto, o pintor realizou seu desejo de expor as paisagens pela primeira vez no território que elas tematizam, implicando na expectativa de um reconhecimento por parte dos que o habitavam.Posteriormente, expôs a série de pinturas na Galeria Millan, que o representa em São Paulo.

Em um depoimento à revista Serrote vol. 14, o pintor paulista nos conta sobre sua reconciliação com o motivo da paisagem, assunto pictórico que sempre o interessou, embora o tenha deixado de lado em meados dos anos 1980, e se tornado conhecido por uma pintura de vocação construtiva. Pintando a partir da memória, o jovem Paulo Pasta buscava sintetizar e idealizar a luz incidente nas diversas estações do ano e horários do dia nos canaviais que se estendem pelos arredores de Ariranha, sua cidade natal, no interior do estado de São Paulo. Desse período, são mais conhecidas as pinturas a pastel e lápis de cor, entre outras, que aludem a cenas mais explicitamente urbanas, mas que ainda se distanciavam em muito do trabalho maduro do pintor.

Segundo Pasta, a leitura recente de uma biografia de Vincent Van Gogh o colocou em contato com a obra de alguns pintores de paisagem que desconhecia, o que o motivou fortemente a pintar paisagens novamente. No entanto, é curioso que o pintor tenha feito a opção de pintá-las de uma forma aparentemente tradicional; são paisagens que pouco remetem à sua produção pictórica mais conhecida. Seria lícito esperar de Paulo Pasta uma síntese geométrica da paisagem, feita com grande rigor e elaboração no calibre de tonalidades e cromatismo; no entanto, são paisagens com "cara" de paisagem, que, para o olhar 


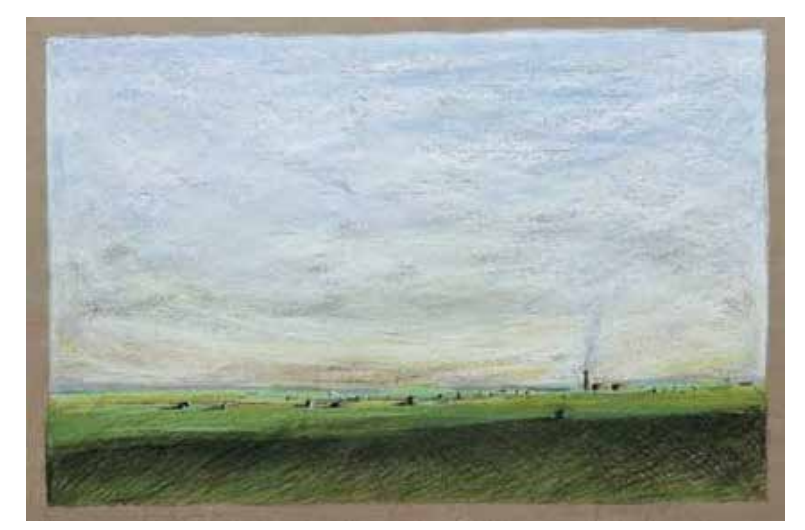

Acima [imagem 93], Paulo Pasta, Da série Canaviais - Lápis de cor sobre papel - 33 x $48 \mathrm{~cm}, 1984$ Fonte:https://alinehannun.blogspot.com/2014/05/ paisagem-e-redescoberta-na-obra-de.html apressado, não colocam qualquer questão clara ou novidade ao contexto visual, e que de forma alguma teriam sido feitas por um pintor como ele. E é esse o primeiro ponto a ser discutido acerca de suas paisagens.

O que leva um pintor maduro a assumir uma face pictórica aparentemente tão distante daquela de sua investigação consolidada, a encarnar um heterônimo artístico? Seria demasiado óbvio dizer que o pintor simplesmente precisa extravasar, relaxar, soltando as rédeas do controle que sufoca sua pesquisa mais “séria” para reencontrar algum lazer, alguma alegria, uma leveza que o aproxime novamente do prazer espontâneo de seu ofício; outra resposta fácil poderia ser a de que ele precisa da alternância para sair de sua segurança, de sua "zona de conforto", colocando-se novamente diante das dificuldades e inseguranças elementares do embate com sua linguagem, podendo assim nutrir-se de algum frescor, do brio criativo que lhe dê forças renovadas para enfrentar a sua pesquisa. Em entrevista ao IFF ${ }^{14}$, na ocasião da abertura de sua exposição em Ribeirão Preto, onde primeiro expôs essa nova vertente de seu trabalho, Paulo Pasta não invalida nenhuma das duas hipóteses. Ao iniciar seus estudos, o contato literário com a experiência de um Van Gogh revelou a Pasta pintores de paisagem pouco conhecidos, das Escolas de Haia e Barbizon, o que já foi suficiente para trazer a ele um interesse renovado pelo motivo.

"O que eu sinto é um prazer enorme em fazer, isso eu sei. Parece que eu virei criança de novo, pintando...um prazer incrivel de pintar. $\mathrm{E}$ isso talvez não me deixe parar... eu não parei, eu continuo fazendo, né? E eu gostaria muito que, esse prazer, [...] eu conseguisse passar para o observador. Sabe? E gosto quando as pessoas falam "Puxa vida, que bonito, que gostoso, que vontade de pintar...isso é compensador pra mim, isso é bom." 15

A fala do pintor parece nos validar a primeira hipótese levantada, o que nos revela 
14. A entrevista contém trechos gravados durante a montagem da exposição "Fábula da Paisagem", que durou de 16 a 20 de maio de 2015, em Ribeirão Preto - SP, no Instituto Figueiredo Ferraz. Os trechos foram transcritos por mim a partir do vídeo disponível em https://www.youtube.com/watch?$\mathrm{v}=\mathrm{HdDQ} 1 \mathrm{S3}$ owIo a despretensão e desenvoltura que tem o pintor ao se libertar de uma certa preocupação constante em produzir “Arte”. É sintomático que, em relação à sua pintura “comum”, esta pintura de paisagens seja mais acessível ao público em geral, e que a transmissão da "vontade de pintar", que ele sentiu ao rever as paisagens, seja algo que o pintor almeja alcançar. $\mathrm{O}$ que, no entanto, ainda nos diz muito pouco sobre suas intenções e a relação que estabelece com seu trabalho reconhecido.

Em outro trecho da entrevista, Paulo Pasta nos coloca a centralidade da memória no desejo pelas paisagens, antes uma necessidade autobiográfica do que a da apreensão ou registro de algo, numa revisão do seu embate inicial com a paisagem, trinta anos antes:

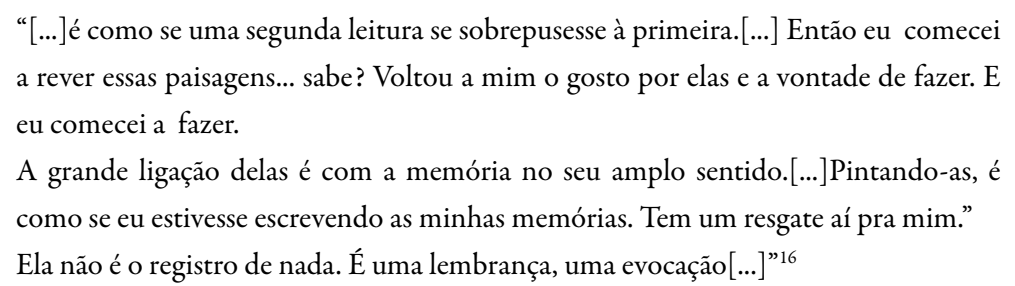

Em seguida, alguns índices de um contraponto interpretativo que o próprio pintor faz com sua "outra" pintura começam a surgir, na medida em que empresta de um pensamento do "corpo" fenomenológico a questão da promiscuidade entre uma interioridade e uma exterioridade. Nesse sentido, as paisagens seriam, para ele, um outro perfil, exterior, de seu próprio corpo, cuja face interior identifica com sua pintura mais conhecida. Uma referência literária à poesia de Francisco Alvim, em um verso do poema “O Corpo", publicado no livro O Sol dos Cegos, serve de apoio à sua fala:

“'Há um fora dentro da gente, e fora da gente, um dentro...’ sabe, é fenomenologia, mas a poesia diz duma maneira mais bonita, né? Mais simples.

[...] Sempre pensei que estou tentando construir um "dentro", nesses meus trabalhos 

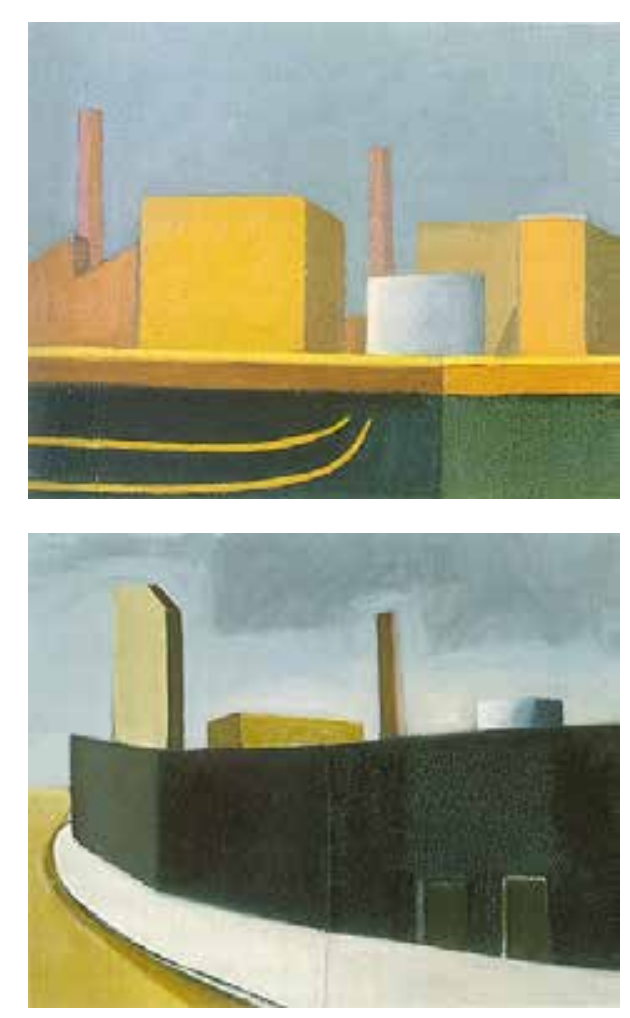

15. Idem.

16. Ibidem.

17. Ibid.

No topo da página [imagem 94] Paulo Pasta. Sem titulo, - óleo s/ tela, 40x50 cm, 1986.

Fonte: http://enciclopedia.itaucultural.org.br/

Na sequência [imagem 95], Paulo Pasta, Sem título

- óleo e areia s/ tela, $40 \times 50 \mathrm{~cm}, 1986$.

Fonte: http://enciclopedia.itaucultural.org.br/ comuns. [Os trabalhos] Têm uma interioridade, uma luz interna. E isso eu vejo, aqui, fora, nesse "fora"das paisagens também. Sabe? Esse dentro e esse fora, se revezam. É um revezamento desse dentro e desse fora, mas é a mesma questão. É um mesmo núcleo." ${ }^{17}$

No trecho seguinte de sua fala, o pintor nos dá pistas daquilo que talvez possa nos elucidar com maior precisão, ou seja, o que é fundamental e comum às duas vertentes que se revezam em sua nova fase: a cor como ator principal na construção de uma espacialidade pictórica, de um "lugar" em si verossímil. Neste trecho, Paulo Pasta toma um posicionamento que contraria o senso comum que se faz sobre suas pinturas, afirmando sua convicção de não ser um pintor "abstrato":

"No meu outro trabalho, [...] eu sempre estou pintando um lugar, eu não sou abstrato. $\mathrm{O}$ que tem ali é a construção de um lugar, então a cor também ajuda a construir esse lugar. A cor é um lugar, e o lugar é a cor, né? Aqui, eu acho que tem mais claro, nas paisagens, a construção verossímil desse lugar. Agora, como dizia o Braque, “o verossímil não é o verdadeiro[...]" 18

De maneira geral, por mais ou menos imprecisas, subjetivas, e até evasivas, que possam ser as declarações que um artista publica sobre o seu próprio trabalho, julgamos que há nelas uma espontaneidade, que, tomado o devido distanciamento, nos possibilita conjecturar criticamente sobre as motivações que trouxeram de volta a paisagem para o seu trabalho. A convicção que o fez retornar às paisagens de sua infância, às suas origens, recolocando-o em contato com um frescor que, provavelmente, sua obra madura não é capaz de lhe trazer, é a de que há uma autêntica afetividade que dela aflora. De fato, o embate com a memória associada à sua paisagem natal talvez preceda qualquer intenção formal, qualquer posicionamento artístico em direção a um diálogo com a historicidade e 
a geograficidade específica dessa paisagem.

A necessidade de um resgate afetivo pela memória da paisagem poderia ser, de maneira um tanto pejorativa, associada à chegada da velhice e de um consequente "relaxamento" trazido por uma "terceira" maturidade. Maturidade tal que não mais teme ser criticada por expressar determinadas fraquezas e anseios afetivos, nem a responder a demandas das novidades, ativismos etc., ansiando pela aprovação de seus pares. Não se trata aqui de endossar ou negar absolutamente tal hipótese; como seria de se esperar, ainda que admita a centralidade do sentimento evocado pelas paisagens, para Paulo Pasta, esbarrar na romantização dessa memória, em um sentimentalismo associado à perda da infância, à vida provinciana e a um contato mais próximo com a natureza, é a maior insegurança em relação a essas pinturas:

"Para mim o verdadeiro está no sentimento que essas paisagens evocam, e na maneira como eu construo isso. Agora, eu não posso ligar só no sentimento...Por que senão fica piegas, fica romantizado. E eu não quero isso."19

Como escapar, então, à "pieguice" de uma memória sentimental no contato com tais pinturas? Cabe a nós elencar aqui critérios de apreciação que levem a uma leitura das obras tendo em conta a questão da memória das paisagens sem que, no entanto, resvalemos no terreno de um sentimentalismo kitsch; como evitar o "insuportável mau cheiro da memória” de que nos fala Drummond? Em seus versos, o poeta nos fala de figuras do aspecto residual da memória, que talvez sejam nela o que há de mais incômodo e mais insistente. Contudo, nas paisagens de Paulo Pasta, como procuraremos demonstrar, não vemos o acúmulo de resíduos de uma tentativa de pintar com os olhos deste ou daquele histórico pintor paisagista; nem uma retórica conceitual sobre a (im)possibilidade de uma pintura como mídia dos nossos tempos de imagens digitais. Pelo contrário, o estranha- 
mento que elas nos causam se dá pela ausência de significações óbvias que contêm, pela fatura de uma pintura que parece aludir a uma tradição não muito precisa, e sem que a citação tome o primeiro plano no discurso da imagem. São paisagens que não contêm personagens, mas que, enquanto conjunto, sugerem uma característica personalidade, um "estado de alma".

Em artigo publicado na Folha de São Paulo em 2016², Alberto Tassinari se debruça sobre a obra de Paulo Pasta tendo em vista suas novas paisagens. A via de entrada escolhida pelo crítico é a que denomina como o "primado do motivo":

"Há uma atenção, na sua pintura, em não comunicar nem mais nem menos do que o motivo exige. Sua pintura é exuberante mas também serena. Como Braque, Paulo Pasta gosta da emoção corrigida pela regra. E basta, para comprová-lo, olhar suas magníficas pinturas com motivos arquitetônicos básicos com arcos, colunas, pilastras e lajes, que se encontram e se desencontram, formam cruzes e as desformam, para avaliar o quanto o motivo arquitetônico conduz sua pintura e a eleva." (TASSINARI, 2016.- p.1)

Para o crítico, uma mesma relação com os motivos arquitetônicos de sua outra produção nos dá a dimensão construtiva das paisagens. A noção da paisagem como construção, que nos leva à questão fundamental do "mito moderno da paisagem intocada" ${ }^{20}$, não poderia aqui ser melhor empregada: ela exprime a essência material do que seria a característica do cenário do interior paulista e o projeto do pintor:

"Paisagens também são construções. O quadrante do Estado de São Paulo definido desde a capital para o oeste e, num giro em sentido horário, para o norte, cobre boa parte de suas terras de boa qualidade. São terras, em geral, planas e manejáveis o bastante para o plantio de diversas culturas.Onde havia a natureza selvagem surge outra, cuidadosamente construída ao longo de geraçôes. A mata 
atlântica que a constituía atualmente só mostra aqui e ali manchas de mato ainda intocado. [...] Esse espaço que se avista da estrada, e do qual a estrada também é parte, espaço meticulosamente construído, foi o motivo escolhido por Paulo Pasta para as suas paisagens recentes. Espaço de sua infância e juventude, décadas depois o pintor o revisita. E com uma quase missão: mostrar pela pintura uma paisagem ainda a ser vista." (2016, p.1)

A construção mental de uma paisagem pictórica se dá pela delimitação de um campo plástico, de uma forma bidimensional no interior da qual será construída a paisagem. Nesse sentido é interessante que as de Paulo Pasta preservem as relações de enquadramento tradicionais à paisagem, assim como suas telas arquitetônicas, mas com a diferença de que suas paisagens são todas a óleo sobre papel, o que implica em uma flexibilização do corpo pictórico que constrói em relação à rigidez ortogonal do chassi das telas. Tal aspecto confere às paisagens bordas indefinidas, numa interface "solta" e orgânica entre as camadas de tinta e o branco do papel que as "emoldura", como numa estampa de gravura, deixando explícita a espessura das camadas e do processo de construção da pintura.

Outro aspecto fundamental, ao qual atenta Tassinari, é a consciência espacial que tem o pintor ao abordar as dimensões concretas de sua construção a favor das necessidades do motivo: há desde pinturas pequenas, confinando os espaços à ordem de grandeza do livro e do material impresso; dimensões médias, mais próximas às da pintura tradicional; e há as grandes dimensões que colam a espacialidade da pintura à escala do corpo. Sobre este aspecto, o crítico nos diz:

20. Cf. DIEGUES, A.C. (2004) O mito moderno da natureza intocada. São Paulo, HUCITEC/ NUPAUB/CEG
"As passagens entre diferentes solos se acumulam em camadas, nos quadros grandes, pintadas de modo mais liso, enquanto nas de motivos menores são mais irregulares. E, quando a paisagem não é a do campo lavrado, mas trechos de ruas de cidades pequenas, os muros interrompem a vista e o pintor diminui assim as dimensões. Não aumenta o que é singelo, embora, um tanto como um Goeldi à luz do dia, deso- 
A curadoria e edição do catálogo da exposição, muito acertadamente, foi capaz de apresentar as paisagens de forma a constituir com elas uma certa narrativa, o que já podia ser lido no titulo "Fábula da Paisagem". A narrativa, no entanto, não foi a princípio pensada pelo artista, e tampouco se desdobra em relação a uma cronologia da produção da série, realizada entre 2013 e 2015. Optamos, nesse caso, por apresentar as imagens todas em sequência destacadas do texto, diferente do que fizemos ao longo da dissertação, como por exemplo em Diebenkorn, privilegiando o sentido narrativo segundo o qual tecemos nossa análise.

Passando agora a uma leitura das paisagens de Pasta tais como aparecem no catálogo, o que podemos observar é, no início do livro, a predominância de uma luz matutina, de um céu nunca limpo, nunca ofuscante, que, aos poucos, passa a ser tomado por nuvens cada vez mais densas. Conduzindo-nos ao início da tarde, a sombra das nuvens atenua o colorido do solo nos planos inferiores, e avista-se ao longe uma chuva que dura pouco, não chegando a molhar o observador. Rapidamente, o céu chuvoso se dissipa, e, ao cair da tarde, somos levados a uma maior proximidade com o plano inferior do quadro, num rebaixamento do horizonte em relação ao observador. Nele vemos índices isolados de uma urbanidade provinciana: um telhado, uma casa atrás de um muro no sol poente. E então, no céu ainda claro, a noite se anuncia pela presença de uma lua ainda quase invisível. À medida que anoitece, vê-se mais céus carregados, novamente as chuvas ao longe e, por fim, a noite iluminada pela lua cheia entre nuvens esparsas. 
Se há alguma personagem reconhecível, além da própria paisagem e da luminosidade em movimento, é a icônica chaminé da usina canavieira, às vezes mais próxima, às vezes soprando fumaça nas nuvens, que já marcava presença nos canaviais de Paulo Pasta nos anos 1980. A composição das pinturas varia pouco, com um horizonte que ora se desloca um pouco para baixo, ora para cima, o céu tomando a maior porção do campo em quase todas pinturas. A perspectiva se anuncia amiúde na fuga diagonal de estreitas estradas de terra, mas, predominantemente, por faixas horizontais de variação de cor e tonalidade que sugerem, por vezes, um terceiro plano, mais próximo ao observador, subdividindo o plano inferior do solo.

Nesta série, não se vê os canaviais pintados com a mesma ênfase de antes: há uma dissolução da definição dos planos cromáticos do solo que sugere, por vezes, o modelado retangular da superfície da cana alta, por vezes o amarelo da palha da cana, remetendo à melancolia das paisagens de Van Gogh, ora à desolação de Edward Hopper, mas predominando o verde das pastagens e o avermelhado da terra. Nas palavras de Tassinari, temos uma leitura interpretativa que vê como positiva a solidão desoladora e sublime que o conjunto das paisagens nos evoca, que não a restringe ao artifício romântico e sentimental:

"Essa desolação das casas perto da estrada de pequenas cidades de interior, seus muros, seu isolamento, não é diversa da solidão que os vastos espaços dos canaviais transmitem. E, mesmo que os observemos desde a estrada, num dia de sol abrasador, ou na tempestade que no horizonte se anuncia e escurece céu e terra, mesmo assim é espaço demais para gente de menos. Essas solidões que Hopper pintou das paisagens americanas também já lavradas e construídas são as antecessoras mais condizentes que encontro das pinturas do interior de uma região por Paulo Pasta. Embora em Paulo Pasta a figura humana esteja ausente.Como se fosse a própria paisagem a solidão que carrega.

Sinal, talvez, de que monoculturas tão vastas não são obras da natureza, não são pastagens naturais, mas a substituição de algo que já não existe.Não há assim nada 

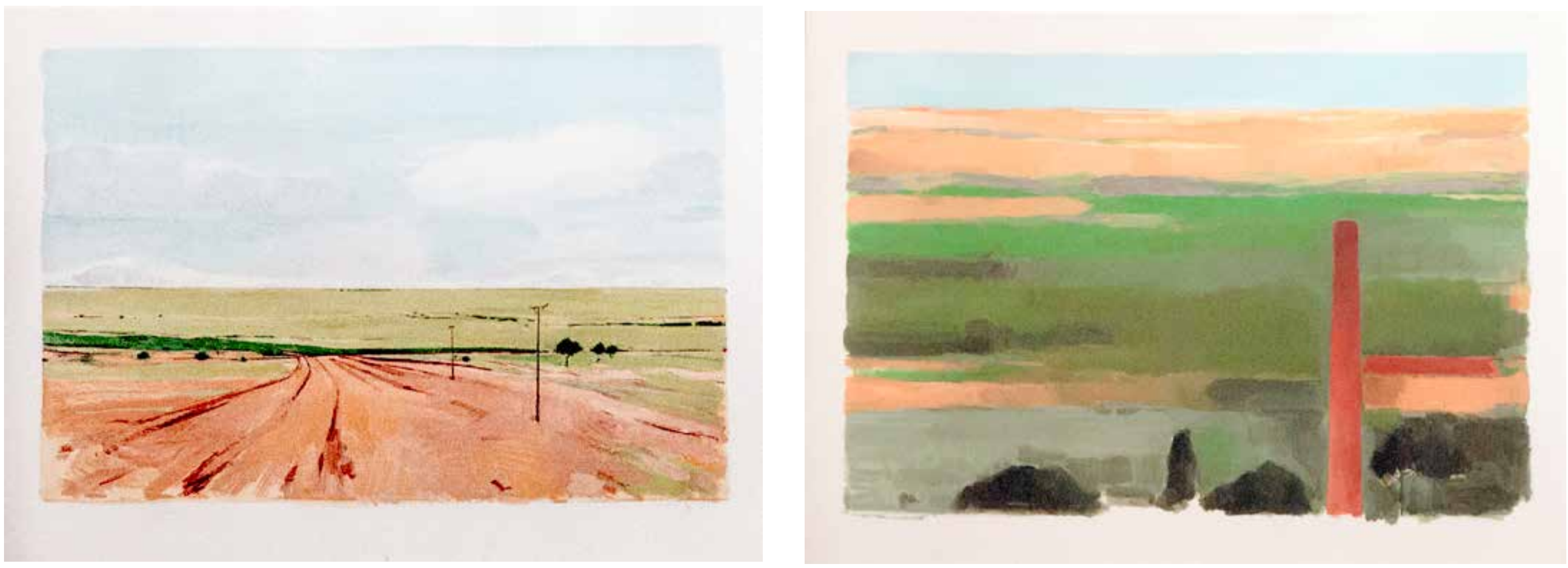

À esquerda [imagem 96], Paulo Pasta. Sem titulo, óleo s/ papel, 150 x $206 \mathrm{~cm}, 2015$.

Fonte: PASTA, 2015.

À direita [imagem 97], Paulo Pasta, Sem titulo,

óleo s/ papel, 150 x $206 \mathrm{~cm}, 2015$.

Fonte: PASTA, 2015. 

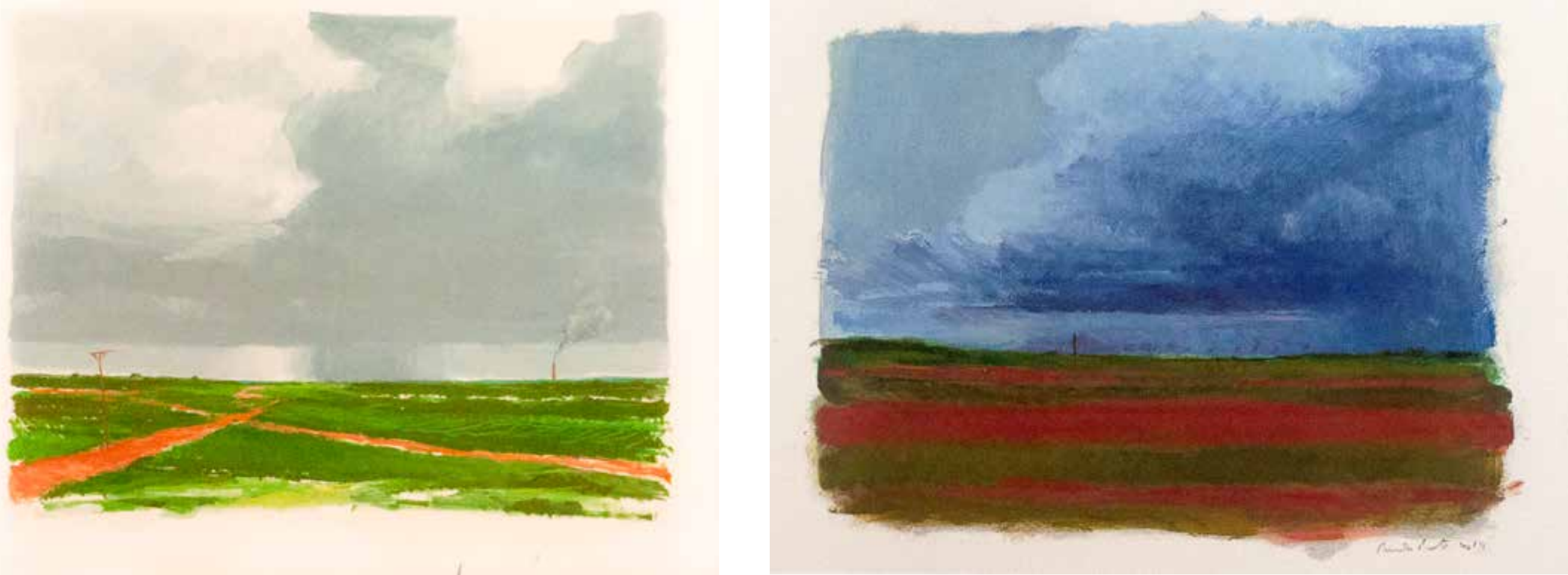

À esquerda [imagem 98], Paulo Pasta. Sem titulo,

óleo s/ papel, 150 x186 cm, 2015.

Fonte: PASTA, 2015.

À direita [imagem 99], Paulo Pasta, Sem titulo,

óleo s/ papel, 24 x 33 cm, 2014 .

Fonte: PASTA, 2015. 

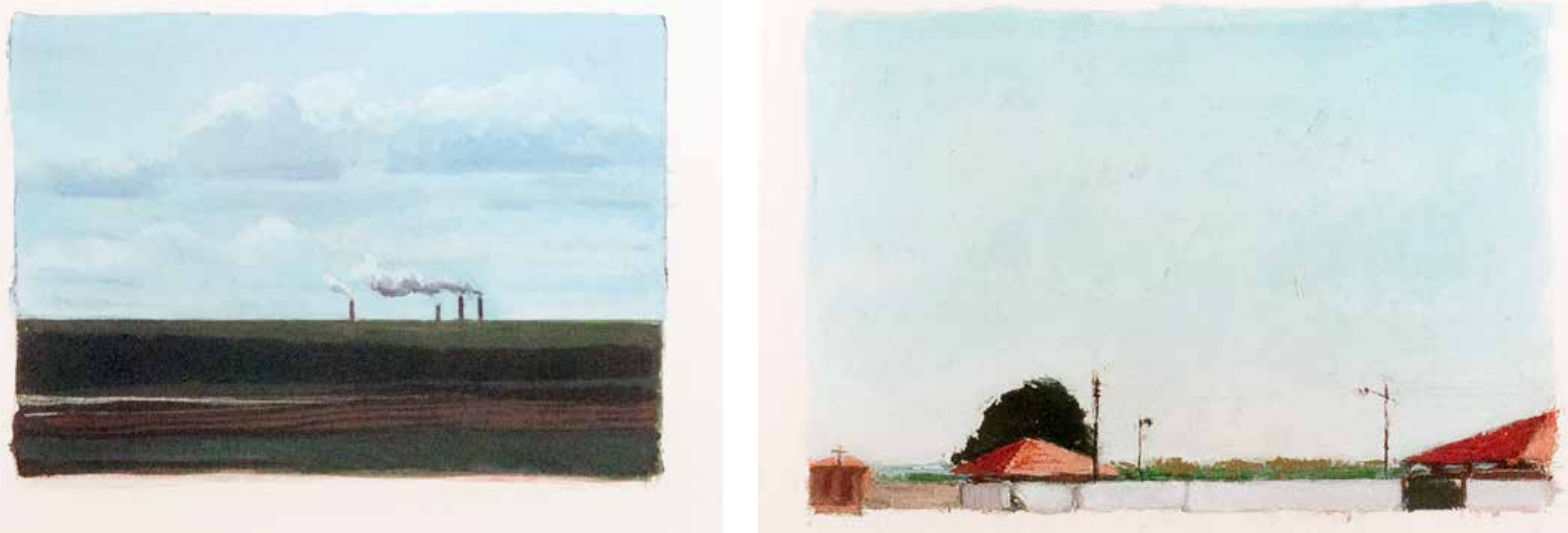

À esquerda [imagem 100], Paulo Pasta. Sem titulo,

óleo s/ papel, $53 \times 78 \mathrm{~cm}, 2015$

Fonte: PASTA, 2015.

À direita [imagem 101], Paulo Pasta, Sem titulo,

óleo s/ papel, $24 \times 33 \mathrm{~cm}, 2013$.

Fonte: PASTA, 2015. 

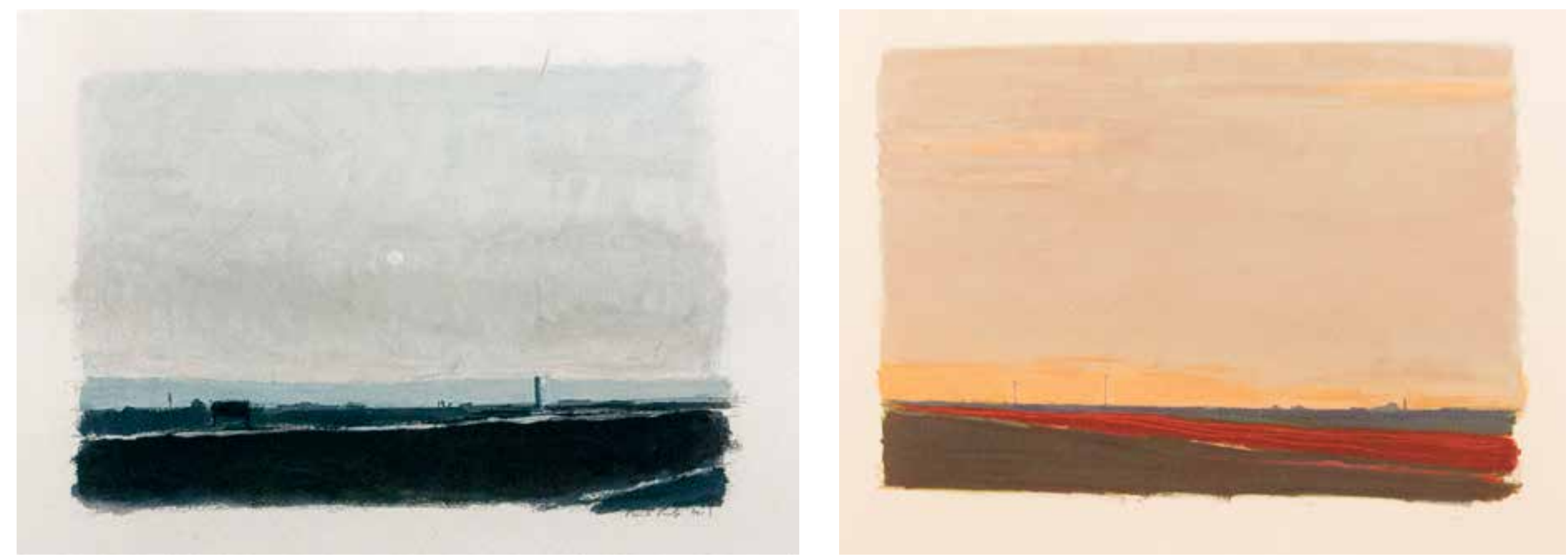

À esquerda [imagem 102], Paulo Pasta. Sem titulo, óleo s/ papel, 24x33 cm, 2013.

Fonte: PASTA, 2015.

À direita [imagem 103], Paulo Pasta, Sem titulo,

óleo s/ papel, 50x65 cm, 2014.

Fonte: PASTA, 2015. 
Ao lado [imagem 104], Paulo Pasta, Sem titulo, óleo s/ papel, 24x33 cm, 2013.

Fonte: PASTA, 2015.

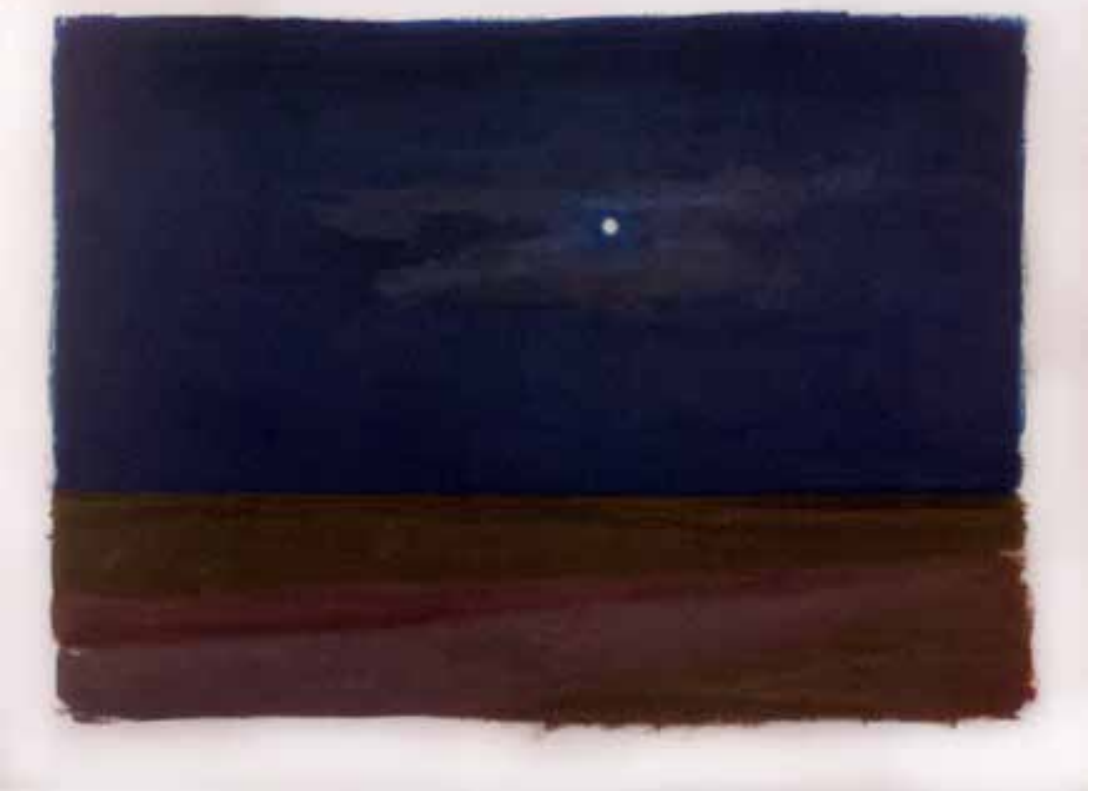

de bucólico ou pitoresco nessas paisagens.Nem são propriamente belas. São mais da ordem do sublime, que apraz tanto quanto dói." (2016, p .1)

Não há qualquer traço de carros, pessoas ou animais, reina uma ausência que sugere uma sutil melancolia, mas que não recorre tampouco a qualquer "figura" simbólica do vazio: a pintura é cheia, não há quase espaço para o branco do papel e o equilíbrio da composição é garantido por certa unidade de uma "liberdade contida" de sua pincelada. A fatura evita, a um só tempo, a virtuose de uma gestualidade expressiva, viciada, unidirecional; a ênfase em um "primitivismo" do traço; e a dissolução esfumaçada, embaçada da pintura fotorrealista ou da pintura clássica.

É visível uma síntese cromática, que confere unidade às pinturas, sem que haja 
uma simplificação fácil da forma. Nota-se aí a qualidade adquirida pela prática do pintor em sua sólida pesquisa cromática e compositiva, que traz às paisagens um aspecto distante da imagem fotográfica, mas ainda assim muito verossímeis, sem que se apele para uma tentativa de reprodução mimética ilusionista, hiperrealista da visão. A aparência de "veracidade" é abordada de forma que nem o detalhe e nem a sua síntese sejam buscados a priori. A intenção de um registro en plein air, da observação direta e a apreensão alla prima da fugacidade do momento não se impõem; não há hierarquias bem definidas na fatura do detalhe e no tratamento dos planos. Talvez por serem feitas, em grande medida, a partir de um misto de memória e invenção, com o apoio eventual da anotação fotográfica. Uma vez que o embate com a imagem fotográfica não é, para Paulo Pasta, uma questão fundamental como o é para outros pintores contemporâneos como Gerhard Richter e Luc Tuymans, é possível para ele tomar emprestado dela a sua objetividade com uma certa desenvoltura de desenhista.

Quanto à forma, ressoam ecos da fase figurativa de Diebenkorn, pintor declaradamente admirado por Pasta, que se mostram na frontalidade e na organização de faixas horizontais de cor, embora no esquema geral, a estrutura compositiva de Pasta seja diferente, privilegiando os vastos céus como nas paisagens holandesas. A fatura tem algo de semelhante a Diebenkorn, pela liberdade da pincelada, ainda que a de Pasta seja menos expressiva, mais dócil. Também as linhas em diagonal que aparecem em algumas das pinturas lembram as diagonais aceleradas da perspectiva do pintor norte-americano.

Quanto à associação com nossas paisagens do rio Pinheiros, também observamos semelhanças pela frontalidade e pelas faixas horizontais, assim como pela presença de discreta de elementos verticais finos como postes e torres, que dão ritmo às composições. Os céus, porém, ocupam uma faixa muito maior e contêm grande dramaticidade, ao contrario dos nossos céus do rio Pinheiros. Fica evidente que a percepção do céu no interior agrário 
totalmente diferente da que se tem na metrópole, mesmo quando se trata da paisagem do rio, que é menos obstruída verticalmente. A quantidade e densidade de elementos visuais da cidade cria uma certa gravidade que puxa o olhar para baixo, o que não ocorre com a mesma intensidade na placidez do interior: nessa paisagem, a organicidade entre o solo e o céu é maior, e a visão do horizonte está quase sempre disponível, o que nunca ocorre nas grandes cidades.

Agora, nos debrucemos sobre o aspecto da memória e da história em sua relação com a experiência a paisagem: a ponte que Paulo Pasta estabelece entre o registro da experiência e as necessidades de sua linguagem pictórica é o que resulta nessas paisagens, que tão fielmente nos trazem a singularidade e sutilezas de uma impressão luminosa e cromática, de uma atmosfera (Stimmung), no sentido de Simmel, do fato que retratam, mas ainda preservando autonomia poética em relação a esse referencial. Nesse sentido, é relevante o que o próprio pintor escreve em seu depoimento à Serrote em abril de 2013, quando iniciava a produção da série:

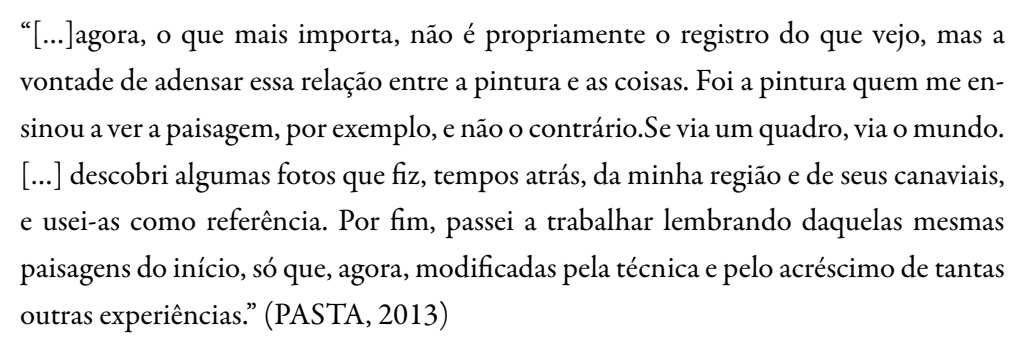
vontade de adensar essa relação entre a pintura e as coisas. Foi a pintura quem me ensinou a ver a paisagem, por exemplo, e não o contrário.Se via um quadro, via o mundo. [...] descobri algumas fotos que fiz, tempos atrás, da minha região e de seus canaviais, e usei-as como referência. Por fim, passei a trabalhar lembrando daquelas mesmas paisagens do início, só que, agora, modificadas pela técnica e pelo acréscimo de tantas outras experiências." (PASTA, 2013)

No mesmo depoimento, o pintor relata, talvez com certo desapontamento, que aquilo que o comoveu nas paisagens de Corot e Daubigny, admirados por Van Gogh, e absorvidos por ele em sua leitura, estava vivo e presente nas suas paisagens do interior paulista. $\mathrm{O}$ traço historicista de sua percepção da paisagem aí estava, impregnado, em meio à 
memória afetiva e a experiência "imediata" da paisagem:

"Quando olhei para o conjunto que elas formaram, na parede do atelier, constatei, um pouco encabulado, que estava, ainda uma vez, descobrindo a mesma coisa: de novo, era por meio da pintura que os arredores de uma cidade do interior paulista conversava com o campo francês, e que a luz do interior do Estado encontrava correspondência com o céu da Holanda. É a pintura que proporciona, para mim, essa união entre o ontem e o hoje, o desejo e o real. Ela foi e ainda é essa ponte, que comporta momentos de fluxo e de interrupção" (2013)

Este ponto de seu depoimento é central à nossa discussão, uma vez que a memória de sua ligação profunda com tais paisagens talvez possa ser "de-romantizada", "dessentimentalizada" pela noção de que a estruturação da sua percepção da paisagem se dá entre a experiência do real e a da pintura. Investe-se, assim, a pintura "figurativa", "mimética" de paisagem, de genuína atualidade: é por meio dela e da história da pintura que se faz ver a paisagem do interior paulista. O que não quer dizer que aquele que não a pinta não a possa ver com igual propriedade; mas o que se quer ressaltar aqui é que a pintura de paisagem pode ser atual e efetivamente se reportar à experiência paisagística sem que esta seja idealizada ou romantizada. Trata-se, contudo, de uma empreitada arriscada, e são poucos os que de fato a realizam. Mas, por mais que resistam nela traços de uma função mimética, representacional, e que esteja revestida de um olhar historicista, tais características não necessariamente a destituem de atualidade e interesse artístico.

Como nos diz Alberto Tassinari: "Que sua pintura se volte nesse tempo para paisagens tem numa espécie de interpretação arquitetônica da paisagem sua razão de ser." (TASSINARI, 2016) Em resumo, pela análise formal, pudemos identificar nas paisagens de Paulo Pasta uma relação constitutiva com a dimensão cromático-arquitetônica que orienta a construção de sua pintura. Tal aspecto de suas pinturas é, portanto, a conclusão a 
que podemos chegar, por hora, de um resquício do embate entre figuração e abstração, em meio ao qual a paisagem flutua com certa liberdade, e que tanto pode interessar à pintura contemporânea.

Relativo ao aspecto da memória e da história, que parece ser um fardo da pintura de paisagens, pudemos constatar, a exemplo de Paulo Pasta, que seu peso não é o que tornaria a pintura de paisagens objeto de interesse menor na arte contemporânea. Como Diebenkorn, Pasta não hesita em remeter-se às tradições da pintura para construir sua poética no contemporâneo, e o faz sem trair à sua vocação construtiva, de uma pintura ordenada e de espacialidades intelectualizadas, assim como se deixa influenciar pelas formas e cores do ambiente em que vive, suas paisagens afetivas.

É, talvez, por meio do embate com as insurgências e sintomas residuais incômodos da memória e da história, que sejamos capazes de vislumbrar uma compreensão e uma apropriação paisagística culturalmente efetiva, tornada linguagem viva, daquilo que vem a ser uma paisagem brasileira contemporânea. $\mathrm{O}$ mais importante talvez seja que finquemos nossos pés no solo da experiência atual, por meio de um olhar expressivo e consciente de que uma das maneiras de se ver a identidade de uma paisagem está na relação com a temporalidade, que pode, ou não, ser prenhe de historicidade e de memória. 


\section{CONSIDERAÇÕES FINAIS}




\section{Considerações finais}

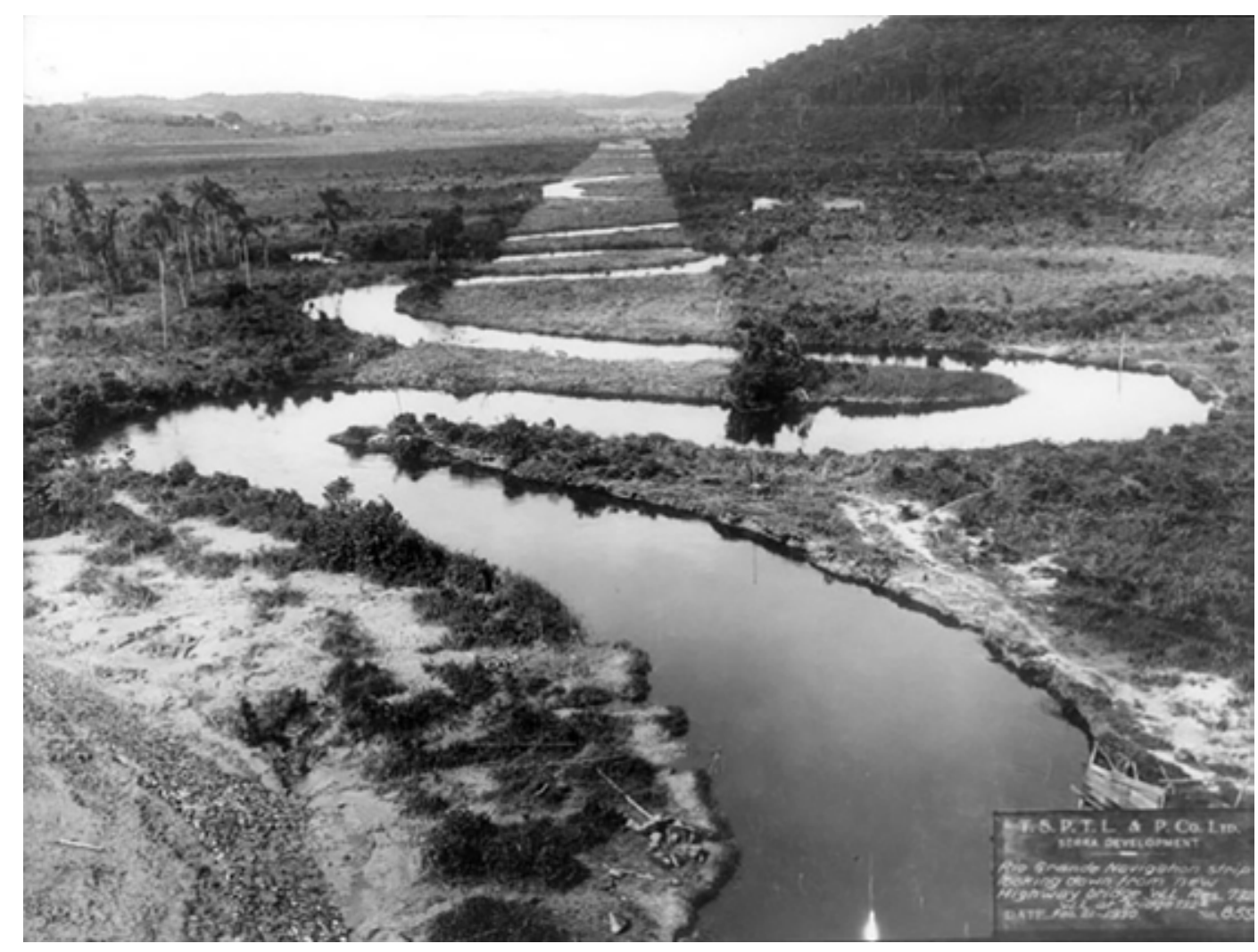

Ao lado, [imagem 105], Desmatamento do traçado do canal do Pinheiros.

$\mathrm{a} / \mathrm{d}, 1930$

Fonte: Arquivo Eletropaulo

Em um retrospecto, a primeira questão que se coloca sobre o desfecho desta pesquisa se dirige à efetividade do formato proposto à dissertação em cumprir com as expectativas colocadas de antemão.

Com a finalidade de preservar a autenticidade da motivação inicial da pesquisa, que se iniciou com a produção de imagens da paisagem do rio Pinheiros, apostou-se numa estrutura de trabalho pouco ortodoxa, em que dois estratos de uma mesma pesquisa correm em paralelo, sob o risco de incorrer em um produto final sem unidade, cindido em 
duas dissertações independentes, sem que um verdadeiro diálogo se estabelecesse entre elas. A opção de partir do exame de imagens de minha autoria, seguindo um critério cronológico de apresentação, para, a partir das questões colocadas por elas, traçar a linha de uma narrativa sobre a paisagem na história da arte, correspondeu a um desejo de afirmação da natureza prática e artística do trabalho sobre a natureza teórica e histórica que o integra.

De fato, a produção prática é o ponto de partida e é anterior ao estudo teórico. Mas o que se mostrou no decorrer da pesquisa é que ambos os estratos, prático e teórico, se retroalimentam, sem que isso ocorra de maneira determinada por causalidades: a característica de uma determinada imagem do rio Pinheiros não resultou do estudo de determinado texto sobre a paisagem, e isso era o que precisava ser afirmado de antemão. Mas, por outro lado, os textos estudados não foram lidos para encontrar explicações para algo que apareceu em alguma imagem por mim produzida.

Levando em conta essas observações, consideramos que a opção tomada de partir das imagens no início de cada capítulo para, em função delas indicar alguma questão da história da paisagem na arte, levou a um equilíbrio dinâmico entre ambas as narrativas: a da viagem pelas margens do rio Pinheiros; e a de uma história da paisagem na pintura, por mais que a proporção em termos de quantidade de texto e de informações entre elas não seja equivalente. Tal equilíbrio, por vezes instável, desliza aqui e ali, oscilando ao longo da dissertação. Ele se dá, todavia, em termos qualitativos, e, se há alguma organicidade entre os dois estratos da pesquisa, ela não se justifica pelo rebatimento entre cada aspecto levantado no exame das imagens e cada informação trazida da história da arte. Se assim fosse, a saudável independência entre as narrativas seria tolhida, e resultaria em excesso de síntese, objetividade e concisão, resultando em um exercício exaustivo e burocrático de leitura de imagens, em que não haveria espaço para a divagação e para uma reflexão mais aprofundada. 
Para expor de modo mais claro como funcionou nosso método de estudo, propõese um exercício de imaginação: suponha- se que caminhamos pela margem de um rio hipotético. À margem esquerda vemos a paisagem empírica, o mundo natural que se nos mostra como percurso imagético pelo rio Pinheiros; no entanto, para vê-la, caminhamos sobre a margem direita, pois ela nos sustenta; é o solo cujo material é a teoria e a história das paisagens na arte. As duas margens caminham no mesmo sentido, mas separadas, espelhando uma à outra, num paralelismo inexato, às vezes se afastando, às vezes se aproximando. Ao longo do percurso, surgem pontes que transpõem de uma margem à outra, unindo duas paisagens que estão naturalmente separadas. Construir pontes entre uma margem e a outra nos permite transitar entre as narrativas, mas essas transições podem ser bruscas, forçadas, e, em outros casos, suaves e ritmadas, sem acidentes.

Realizada a transposição da margem da história para a margem do conhecimento sensível, passamos a olhar para a paisagem da margem teórica, à direita, caminhando sobre solo da arte e da percepção, e isso, legitimamente, nos dota de um novo olhar. A princípio vemos uma outra paisagem, plena de coisas construídas, de ruído e excesso de informações. É a paisagem edificada pela cultura, dos acúmulos e das sobreposições de camadas históricas. Mas à medida que seguimos nosso curso, a visão do outro lado parece ser progressivamente aplainada, seus contrastes se tornam mais orgânicos, e aquela paisagem que era ruidosa e cheia de verticalidades, cruzamentos e informações conflitantes, surpreendentemente passa a se assemelhar àquilo que víamos do lado oposto, antes de cruzar a ponte.

A margem da história e da teoria da paisagem, então, se convertem na paisagem empírica, da experiência sensível, pré-conceitual e pré-reflexiva. Caminhamos mais um pouco, apreciando e contemplando a paisagem, perdendo-nos no ato de olhar a margem oposta, até que, de súbito, outra ponte se coloca à nossa frente. Se devemos cruzá-la ou 
não, cabe à disposição de espírito, ou à necessidade de se chegar a algum local específico, cujo acesso só se dá pelo outro lado. Se aquilo que vemos na margem oposta já não nos informa mais nada e não satisfaz os desejos do olhar, já é hora de cruzar a ponte. E assim sucessivamente, num percurso linear, mas cuja essência é a de ser circular.

Nosso intuito com esta imagem é aludir às idas e vindas que se deram, em nossa pesquisa, entre ver a paisagem segundo a percepção e o fazer artístico, e ver a paisagem segundo a história da arte e o pensamento filosófico. No fim das contas, o que se mostra de um lado, passa a ser aquilo que já se viu no outro, e assim caminhamos pelas margens dos rios das cidades, entre os vaivéns das pontes. O rio Pinheiros, que já foi meandrante e tornou-se canalizado, não deixou de serpentear: é a memória de suas margens que, encarnada na cidade, tomou para si sua dança e seus movimentos transbordantes.

Posto isso, cabe-nos dizer que, de modo geral, não chegamos a uma conclusão definitiva sobre a efetividade do nosso método de trabalho em atingir os objetivos do projeto de pesquisa, de se caracterizar qual é a função de um olhar pictórico em relação às paisagens contemporâneas; assim como não nos foi possível delimitar com alguma precisão em que medida o imaginário atual de uma "paisagem contemporânea" se afastou ou está ainda imbuído de uma estrutura visual proveniente da pintura de paisagens. Para tanto, seria necessária uma extensa e complexa pesquisa iconográfica sobre a produção de imagens contemporâneas referidas à ideia de paisagem, em diversos níveis culturais.

É certo, no entanto, que circunscrevemos um contexto artístico em que se caracterizam aspectos fundamentais do debate sobre a paisagem como representação visual, como a articulação, mediada pela linguagem visual, entre a percepção do ambiente, enquanto experiência sensível, e o imaginário cultural, como manifestação da memória e da história.

Por outro lado, nos compete afirmar que, no âmbito de objetivos mais específicos, 
foram positivos os resultados à seguinte questão colocada: podem o desenho e a pintura da paisagem de um rio urbano nos informar sobre aspectos de um caráter "universal" às paisagens, situando-nos histórica e filosoficamente em relação a elas, de modo a nos indicar "essências" da percepção e da experiência estética da natureza nas cidades de hoje? É possível dizer que sim, e toda a dissertação é um desenvolvimento dessa resposta, pois o privilégio do desenho e da pintura como modos de contato com a paisagem é colocar em suspenso a naturalização da experiência visual e da percepção espacial, de modo a trazer à tona, pela forma, uma série de conteúdos de toda ordem, que só se fazem notar por meio da linguagem visual. Uma vez inscrita sobre o plano visual, a representação do mundo visto nos pode indicar um amálgama de significados e sentidos polivalentes, inconscientes, históricos, míticos, que permeiam o enigma dos rios e das montanhas. 
BIBLIOGRAFIA 
Bibliografia geral

ALPERS, Svetlana. A arte de descrever: A arte holandesa do século XVII. São Paulo: Edusp, 1999. ANDRADE, Carlos Drummond de,A Rosa do Povo. São Paulo : Cia. das Letras, 2012 pp. $71-73$ ARNHEIM, Rudolf. Intuição e intelecto na arte: São Paulo: Martins Fontes, 2004.

BAZIN, André, Ontologia da Imagem fotográfica. p.6 trad. de Qu 'est-ce que le cinema? vol.1, Paris, Editions du Cerf,1958. In. XAVIER, Ismail. A experiência do cinema: antologia. Rio de Janeiro: Ed. Graal : Embrafilmes, 1983

BENJAMIN, Walter. Obras Escolhidas Vol. 1. Ed. Brasiliense, 1994.

BESSE, Jean-Marc. Ver a terra - seis ensaios sobre a paisagem e a geografia - São Paulo: Perspectiva, 2006 BOLLE, Willi. Fisiognomia da Metrópole Moderna: Representação da História em Walter BenjaminSão Paulo : EDUSP, 1994

BOSI, Alfredo. Fenomenologia do olhar. In. NOVAES, Adauto et al. O Olhar - São Paulo: Companhia das Letras, 1988.

CARERI, Francesco. Walkscapes: o caminhar como prática estética. Tradução Frederico Bonaldo. São Paulo: Editorial Gustavo Gili, 2013.

CARUS, Carl G. Nine Letters on Landscape Painting, Written in the Years 1815-1824. Los Angeles: Getty Research Institute, 2002.

CAUQUELIN, Anne. Arte contemporânea : uma introdução; trad. Rejane Janowitzer; boa: Edições 70, 2008

CLARK, Kenneth. Paisagem na Arte. Lisboa : Ulisseia, 1961.

CRAWFORD , William. The Keepers of Light - A history and working guide to early photographic processes. New York: Morgan \& Morgan, 1979.

DARDEL, E. O Homem e a Terra - natureza da realidade geográfica - São Paulo : Perspectiva, 2015

DIDI-HUBERMAN, Georges. A imagem sobrevivente: história da arte e tempo dos fantasmas segundo Aby Warburg - Rio de Janeiro: Contraponto, 2013.

DIEGUES, A.C. O mito moderno da natureza intocada. São Paulo, HUCITEC/NUPAUB/CEG 2004

FLORIÊNSKI, Pável. A perspectiva inversa. São Paulo: Editora 34, 2012. 
FLUSSER, Vilém, Filosofia da Caixa Preta - Ensaios para uma futura filosofia da fotografia. São Paulo: Hucitec, 1985

FOSTER, Hal. KRAUSS, Rosalind. BOIS, Yves-Alain.

BUCHLOCH, Benjamin H.D., Art since 1900 - modernism - antimodernism - postmodernism.London: Thames \& Hudson, 2004.

GARRAUD, C. L'idée de nature dans l'art contemporain, Paris, Flammarion, 1994.

GOETHE, Johann W. Doutrina das Cores - São Paulo : Nova Alexandria , 1993.

Viagem à Itália , São Paulo ; Cia. das Letras, 1999

GOMBRICH, Ernst H. Arte e ilusão - um estudo da psicologia da representação pictórica, Rio de Janeiro: Martins Fontes, 1986

Meditações sobre um cavalinho de pau. São Paulo : Edusp, 1999.

HADOT, Pierre. O Véu de Ísis - Ensaio sobre a história da ideia de natureza. São Paulo: Loyola, 2006. São Paulo : Ed. Loyola, 2006.

HARMON, Katharine. The map as art : contemporary artists explore cartography. New York: Princeton Architectural Press, 2009.

HILLMAN, J. - Cidade e Alma - Studio Nobel, São Paulo; 1a edição, trad.: Gustavo Barcellos e Lúcia Rosenberg, 1993.

MATOS, Olgaria. História Viajante - notações filosóficas. São Paulo : Studio Nobel, 1997.

MERLEAU-PONTY, Maurice. Fenomenologia da percepção - São Paulo: Martins Fontes,1994. O Olho e o Espírito. São Paulo: Cosac \& Naify, 2004.

A natureza. São Paulo: Martins Fontes, 2006.

Os pensadores - Textos escolhidos - São Paulo: Abril, 1980.

O visível e o invisível . São Paulo : Perspectiva, 2014 . Conversas. São Paulo : Martins Fontes,

NAKAGAWA, Rosely. Rubens Matuck: Tudo é Semente. São Paulo : Ed. SESC São Paulo, 2017. NOVAES, Adauto et Al. O olhar. São Paulo : Cia. das Letras, 1988.

PALLAMIN, Vera M. Forma e percepção - considerações a partir de Maurice Merleau-Ponty. - São Paulo: Fauusp, 1996.

PANZINI, F. Projetar a Natureza - A arquitetura da paisagem e dos jardins desde as origens até a época contemporânea. São Paulo: Senac, 2013. 
PASTA, Paulo. A educação pela pintura / Paulo Pasta - São Paulo: WMF Martins Fontes, 2012.

PEIXOTO, Nelson B. - Paisagens Urbanas - São Paulo: Marca D’Água/ SENAC, 1996 . - Paisagens Críticas: Robert Smithson: arte, ciência e indústria. São Paulo: Editora Senac São Paulo, 2010.

PLATÃO, A República. Introdução, tradução e notas de Maria Helena da Rocha Pereira. São Paulo: Fundação Calouste Gulbenkian, 2005.

RITTER, Joachim. Paisagem - função estética na sociedade moderna, p.63 - in: Paisagemtextos - vol.3. trad. e org. Vladimir Bartalini. São Paulo: FAUUSP, 2013. ROGER, Alain. Court Traité du Paysage. Paris, Gallimard, 1997.

ROSA, João G. Primeiras estórias. Rio de Janeiro : J. Olympio. 1977

RYCKMANS, Pierre. As anotações sobre pintura do monge Abóbora Amarga. Campinas: Unicamp, 2013.

SANT ' ANNA, Affonso R., Desconstruir Duchamp - arte na hora da revisão. Rio de Janeiro: Vieira \& Lent, 2003.

SALLES, Cecilia A. Gesto Inacabado - processo de criação artística. São Paulo : Intermeios, 2011.

SCHAMA, Simon. Paisagem e Memória. São Paulo: Companhia das Letras, 1995.

SIMMEL, Georg - La tragédie de La culture et autres essais, Paris: Editions Rivages, 1988 - In: Paisagemtextos - vol.1, trad. e org. Vladimir Bartalini. São Paulo: Fauusp, 2013.

- A metrópole e a vida mental In.VELHO, Otávio Guilherme, O fenômeno urbano, Rio de Janeiro, Zahar editores, 1967.

SONFIST, Alan. Art in the land - A critical anthology of environmental art. New York: E.P. Dutton, Inc., 1983

STRAUS, Erwin. Da diferença entre o sentir e o perceber - texto correspondente ao capítulo VII de Le sens des sens. Contribution à l'etude dês fondements de La psychologie In: Paisagemtextos - vol 1. Trad. e org. Vladimir Bartalini. São Paulo: Fauusp. 2013.

TORRANO, Jaa. O mundo como função de musas in; HESÍODO, Teogonia : A origem dos deuses / Hesíodo : estudo e tradução de Jaa Torrano. São Paulo : Iluminuras, 2007

VINCI, Leonardo. Tratado de la pintura y del paisaje, sombra y luz. Joaquin Gil. Buenos Aires. 1944 
ALVES, Teresa. Paisagem - Em busca do lugar perdido. In.: FINISTERRA, XXXVI, 72, 2001.p 67-74 ANDRIOLO, A. Metamorfoses do olhar na viagem de Goethe à Itália - in: ArtCultura, Uberlândia, v.13,n.23, 2011, p.113-127

HATOUM, Milton. O rio é a minha memória. Texto publicado em francês na "Magazine-Air France", dezembro, 2018, trad. Michel Riaudel. Publicado online pelo autor em 12/02/2019 e acessado em http:// facebok.com/miltonhatoumescritor/ em 21/02/2019.

MOTTA, Flávio. Desenho e Emancipação. In “Sobre o desenho”. São Paulo: Centro de Estudos Brasileiros do GFAU USP, 1975.

PUGLIESE, Vera. A história da arte como montagem de tempos anacrônicos. Camila Aparecida Braga Oliveira; Helena Miranda Mollo; Virgínia Albuquerque de Castro Buarque (orgs). Caderno de resumos \& Anais do 5o. Seminário Nacional de História da Historiografia: biografia \& história intelectual. Ouro Preto: EdUFOP, 2011.

ROGER, Alain. O nascimento da paisagem no ocidente. Conferência realizada no I Colóquio Internacional de História da Arte Comitê Brasileiro de História da Arte / Comitê International d'Histoire de l’Art São Paulo 5-10 de setembro de 1999.

TASSINARI, Alberto. Notas sobre a pintura de Paulo Pasta.10/01/2016 . Folha de São Paulo,

disponível em http://wwwl.folha.uol.com.br/ilustrissima/2016/01/1727370-notas-sobre-a- pintura-de-paulo-pasta.shtml

VIVACQUA, Flavia. 2012. Arte e ecologia. Disponível em $:<$ https://flaviavivacqua. files.wordpress.com/2012/05/arte-e-ecologia-contec3bado-de-oficina- flavia-vivacqua.pdf >. Acesso em: fevereiro/18.

\section{Dissertações acadêmicas:}

BATLLE Alexandre O. O papel do desenho na formação e no exercício profissional do arquiteto - conceitos e experiências. Dissertação de mestrado apresentada à FAUUSP. São Paulo, 2011.

CARVALHO, Beatriz F.R. Caminhar na cidade - Experiência e representação nos caminhares de Richard Long e Francis Alys; depoimentos de uma pesquisa poética. Dissertação de mestrado apresentada à FAUUSP. 
São Paulo, 2007.

COLE, Ariane D. O Processo de Criação na Poética da Paisagem. Tese de doutorado São Paulo: Fauusp, 2004.

DELIJAICOV, Alexandre Carlos Penha. Os rios e o desenho urbano da cidade: proposta de projeto para a orla fluvial da Grande São Paulo. São Paulo: Tese de doutorado apresentada à FAUUSP. São Paulo, 1998 FRANCO, Fernando M. A Construção do Caminho. São Paulo, 2005.

GRINSPUM, Gabriel Rodrigues. Metamorfose da várzea paulistana: energia, saneamento e urbanização. Dissertação de mestrado apresentada à FAUUSP. São Paulo, 2014.

HEPNER, Alexandre, Desenho urbano, capital e ideologia em São Paulo: centralidade e forma urbana na Marginal do Rio Pinheiros - Dissertação de mestrado apresentada à FAUUSP. São Paulo, 2010.

ISAAC, Cristiana B. Arte e paisagem. Estudo de obras contemporâneas brasileiras. Dissertação de mestrado apresentada à FAUUSP. São Paulo, 2013.

ISODA, Gil T.T. Sobre desenho - estudo teórico-visual. Dissertação de mestrado apresentada à FAUUSP. São Paulo, 2013.

PASTORE, Júlio Barêa. O cerrado enquanto paisagem: a dinâmica da apropriação paisagistica do território. São Paulo, 2014.

SALVADOR, Luísa G. N. S. - Paisagem - Acção (1960-1970). Dissertação de mestrado apresentada à FSCH. Lisboa, 2012.

SANTOS, Eliana P. S. A vontade de paisagem: genealogia de concepções de percep̧̧ão espacial, da teoria à prática artística e arquitetônica. Dissertação de mestrado apresentada à DARQ - FCTUC. Coimbra, 2006.

\section{Catálogos:}

PASTA, P. Fábula da Paisagem / Paulo Pasta - São Paulo: Galeria Millan, 2015.

\section{Websites consultados}

http://www.artsy.net

http://www.galeriamillan.com.br

http://www.gerhard-richter.com 
http://enciclopedia.itaucultural.org.br/

http://www.diebenkorn.org

http://www.robertsmithson.com

https://www.youtube.com/watch?v=HdDQ1S3owIo

http://www.wikiart.com

http://www.wikipedia.com 
